\title{
23. GEOCHEMISTRY AND PETROLOGY OF VOLCANIC ASHES RECOVERED FROM SITES 881 THROUGH 884: A TEMPORAL RECORD OF KAMCHATKA AND KURILE VOLCANISM ${ }^{1}$
}

\author{
L.-Q. Cao, ${ }^{2}$ R.J. Arculus, ${ }^{2,3}$ and B.C. McKelvey ${ }^{2}$
}

\begin{abstract}
One hundred and fifty-four ash layers were sampled during ODP Leg 145 at Sites 881, 882, 883, and 884, in the northwest Pacific. The Miocene to Recent ashes are interpreted to be explosive eruption products of the Kurile-Kamchatka arc system. On the basis of number and thickness of ash layers within given time intervals, it appears that at least five major pulses of subaerial volcanism occurred during the last $3 \mathrm{Ma}$, with a remarkable increase in the number and thickness of layers commencing at $\sim 2.6$ $\mathrm{Ma}$. Ash layers are absent in the age interval 34.4 to $6.3 \mathrm{Ma}$, but are present in the lower Oligocene to middle Eocene. High $\mathrm{Ba} / \mathrm{Nb}$ $(\sim 200)$ of the Paleogene ashes is consistent with derivation from an island arc rather than mid-ocean ridge or hot-spot source.

Several huge explosive events are inferred, with the thickest ash layer $\leq 2.5$ meters at Site 884 . Dry clay-free ash colors are without exception light- to yellowish grays (hue $2.5 \mathrm{Y}$ ). The ashes consist of microlites (plagioclase, clinopyroxene, quartz, and $\mathrm{Fe}-\mathrm{Ti}$ oxides) and vitric shards. Elongate $(\approx \geq 5$ to $\approx<100 \mathrm{~mm})$, tubular, and bubble wall fragments are ubiquitous and were probably derived from plinian eruption cloud fallout at distances in excess of the present $600 \mathrm{~km}$ from the active arc.

Major element analyses of about 2000 individual vitric shards were obtained by electron microprobe, and the abundances of a range of large ion lithophile (including rare earth) and high field strength trace elements have been determined for a subset of about 100 ash layers by inductively coupled plasma source mass spectrometry. ${ }^{143} \mathrm{Nd} /{ }^{144} \mathrm{Nd}$ and ${ }^{87} \mathrm{Sr} /{ }^{86} \mathrm{Sr}$ were determined for an acid-leached subset of 40 of these vitric shards.

A compositional spectrum from basaltic andesite through dacite to rhyolite exists in these ash layers, but the majority of them are rhyolitic. An extensive range from low- through medium- to high- $\mathrm{K}$ compositions is present, but all are tholeiitic on the basis of the $\mathrm{FeO} * / \mathrm{MgO}$ vs. wt $\% \mathrm{SiO}_{2}$ criterion. On the basis of distinctive major and trace element characteristics for the Miocene and younger ashes, we recognize 12 compositional groupings. These range in terms of rare earth element (REE) abundances from light REE-depleted through relatively unfractionated to light REE-enriched compared with chondrites. The degree of relative light REE enrichment is positively correlated with the K content. Negative Eu anomalies are characteristic of the majority of the samples. Most of the samples overlap the isotopic range of the currently active Kamchatka-Kurile arc with $\varepsilon_{\mathrm{Nd}}$ of $\sim+8$ and ${ }^{87} \mathrm{Sr} /{ }^{86} \mathrm{Sr}=0.7031$ to 0.7038 , but some samples range to a lower $\varepsilon_{\mathrm{Nd}}$ of +3 and ${ }^{87} \mathrm{Sr} /{ }^{86} \mathrm{Sr}$ of $\sim 0.7045$.

Nine trace elements ( $\mathrm{Rb}, \mathrm{Ba}, \mathrm{Th}, \mathrm{U}, \mathrm{La}, \mathrm{Ce}, \mathrm{Y}, \mathrm{Yb}$, and $\mathrm{Lu}$ ) are particularly useful for discriminating between the compositional groups within the ashes, and for comparison with the major subaerial volcanic belts in the Kurile-Kamchatka arc system. Some strong variations in abundances and ratios $(\mathrm{Rb} / \mathrm{Ba}, \mathrm{Th} / \mathrm{U})$ were noted and may prove to be diagnostic of particular geographic sources.
\end{abstract}

\section{INTRODUCTION}

Spatial variation of chemical composition and physical parameters such as volumes of erupted materials within island arcs were recognized by Kuno (1959) and Sugimura, (1960). Appreciation of the fundamental role of island arc magmatism in the genesis of the continental crust (Taylor, 1967) stimulated a search for evidence of temporal controls on petrogenesis leading to suggestions that nascent low-alkali through intermediate- to highly alkaline "mature" systems correlated with changes in crustal character from intraoceanic to continental (Baker, 1968; Gill, 1970). Within any individual arc however, the typically incomplete or poor onland exposures render deciphering the temporal record an awkward task and restrict our view to a narrow period of development. Experience has shown that lengthy records of arc activity, either as ash- or volcaniclastic-rich turbidite layers, can be obtained by drilling deposits in the marine realm that are optimally placed to avoid disturbance and reworking with reasonable penetration thicknesses. Disadvantages include the difficulty of precisely identifying the sources of these materials, technical drilling problems with the recovery of coarse clastic sequences, the possibil-

\footnotetext{
${ }^{1}$ Rea, D.K., Basov, I.A., Scholl, D.W., and Allan, J.F. (Eds.), 1995. Proc. ODP, Sci. Results, 145: College Station, TX (Ocean Drilling Program).

${ }^{2}$ Department of Geology and Geophysics, University of New England, Armidale, New South Wales 2351, Australia.

${ }^{3}$ Present address: Department of Geology, Australian National University, Canberra. ACT 0200, Australia.
}

ity of incomplete records through erosion and nondeposition, and the problems of diagenetic change as a result of exposure to seawater.

Concentrations of ash and distinct ash layers can persist despite slumping and/or erosion by bottom currents and bioturbation. We have found that fresh volcanic glass can persist in layers up to $35 \mathrm{Ma}$ old, and even some older. Single eruptive episodes were probably responsible for homogeneous layers (type I of Huang, 1980) whereas multiple eruptions from different sources or mixed magmas are most likely the origin of heterogeneous layers (type II of Huang, 1980). Shards, tubular-elongate micropumice, bubble wall, and U- to Yshaped fragments are common and probably associated with Plinian eruptions. Apparently pristine igneous trends can be distinguished from analysis of many of these materials, and magmatic $\mathrm{Sr}$ isotopic ratios have been recovered with comparatively mild leaching treatment of glass shards.

During late 1988 through late 1992, the Ocean Drilling Program (ODP) successfully recovered extensive cores of volcaniclastic materials overlying basement from a number of sites within ash fallout/ pumice drift range of convergent margins of the western Pacific. The areas targeted by these studies include the Sulu and Celebes Seas (Pouclet et al., 1991), Izu-Bonin forearc (Arculus and Bloomfield 1992; Fujioka et al., 1992), Izu-Bonin backarc (Rodolfo et al., 1992), Japan Sea (Pouclet et al., 1992; Pouclet and Scott, 1992), and Vanuatu (Baker et al., 1994). More generalized regional comparisons have also been documented by Cambray (1991). Allied with the results of analytical and interpretative efforts targeted on cores obtained during the predecessor efforts of the Deep Sea Drilling Project (DSDP) in some of these systems, we now have an improved appreciation for the factors that appear to be critical in controlling aspects of the geochem- 
istry. Some of the questions and issues that have been addressed by these efforts include a number that have long been important in studies of supra-subduction zone magmatism:

1. Are there any temporal changes in the geochemistry of arc magmas;

2. If so, are these regular, erratic, or blends of these end-member behaviors;

3. Can we detect crustal growth using geochemical parameters believed to correlate at least globally with crustal thicknesses;

4. Can changes in the style of eruptive activity and/or geochemistry be attributed to distinct tectonic events;

5. Is there interarc synchroneity of major periods of explosive activity;

6. Do episodes of major explosive activity in arcs correlate with climate change?

The advanced piston coring techniques deployed during Leg 145 were successfully used to recover substantial distal records of volcanic activity of the Kurile-Kamchatka arc in sediments ranging in age from middle Eocene to Holocene on the inbound Pacific plate. Recoveries approaching $100 \%$ at Sites $881,882,883$, and 884 provide an unique record of subaerial explosive volcanism in the northwestern Pacific Ocean. About 360 ash layers, ranging from less than $1 \mathrm{~cm}$ to more than $370 \mathrm{~cm}$ in thickness, were observed at Holes $881 \mathrm{~A}$, $881 \mathrm{~B}$, and $881 \mathrm{C}$ drilled about $700 \mathrm{~km}$ southeast of the southern tip of Kamchatka (at $47^{\circ} 6^{\prime} \mathrm{N}, 169^{\circ} 29^{\prime} \mathrm{E}$ ), and at Holes $882 \mathrm{~A}, 883 \mathrm{~B}$ and $884 \mathrm{~B}$ drilled on the upper part of Detroit Seamount (at $50^{\circ}-51^{\circ} \mathrm{N}$, $167^{\circ}-168^{\circ} \mathrm{E}$ ) about $700 \mathrm{~km}$ east southeast of Petropavlovsk (Fig. 1). Site 881 also represented the northernmost continuation of a northsouth traverse initiated on DSDP Leg 86 (Heath, Burckle, et al., 1985), and the Detroit Seamount sites can be compared with the shorter recovery from the Meiji Seamount DSDP Leg 19 Site 192 (Creager, Scholl, et al., 1973) (Fig. 1).

A strategy of sampling based on representative downhole coverage was adopted, and about $40 \%$ of the recorded ash layers (totaling 130 out of $\sim 325$ ash layers) were collected for mineralogical, bulk major element, trace element, and isotopic analysis. In order to place the geochemical aspects of the study in context, a general understanding of stratigraphic and lithological characteristics of the volcanic ash layers is essential, requiring detailed information for every ash layer such as magnetic susceptibility, age, depth, thickness, color (dry and wet), morphologies of vitric shards, and surrounding lithology.

In this study, we report major-element analyses of individual glass shards obtained by electron microprobe (EMP), bulk layer analyses of trace elements by inductively coupled plasma source mass spectrometry (ICP-MS), ${ }^{143} \mathrm{Nd} /{ }^{144} \mathrm{Nd}$ and ${ }^{87} \mathrm{Sr} /{ }^{86} \mathrm{Sr}$ for acid-leached bulk glass samples, and representative EMP analyses of microlites of plagioclase, pyroxene, Fe-Ti oxides, biotite, and amphibole. With these data, we attempt to track compositional changes through time. Identification of possible ash sources on the basis of geochemical comparisons with published analyses for the different volcanic belts in Kurile-Kamchatka is at an early stage. We regard this as a preliminary effort in view of the wealth of samples yet to be studied and the variety of integrative analytical approaches still required.

\section{GENERAL GEOLOGY AND PREVIOUS STUDIES}

The general prevailing wind and current directions coupled with the relative inactivity of the western Aleutian arc lead us to believe that the predominant source of the ash layers recovered at Sites 881 to 884 is the Kurile-Kamchatka arc system. We note that prominent although sparse ash layers derived from the Honshu-Kurile arc system were reported by Natland (1993) at Site 810 on the Shatsky Rise, at present located at some $1600 \mathrm{~km}$ from the arc. Thus, in terms only of distance of travel, a Kurile-Kamchatka source is plausible. In addition, the general overlap of compositions recovered at Site 881 vs. Sites $882-884$, including the distinctively potassic groups, are more likely to have been derived collectively from the nearest potentially active arc source.

The considerable body of literature published on the KurileKamchatka arc system by Russian scientists since the 1950 s relates to regional geology, geophysical characteristics, petrology, geochemistry, and physical volcanology (Fedotov and Masurenkov, 1991). The Kurile-Kamchatka arc has a total length of $2000 \mathrm{~km}$ and is about 400 $\mathrm{km}$ wide on the Kamchatka peninsula. Three major, active subaerial volcanic belts are distributed parallel to the Kurile-Kamchatka trench in the peninsula. These belts, located at different tectonic positions above the Kurile-Kamchatka subduction zone, are (1) Sredinny (or Central) Range (SR); (2) Central Kamchatka Depression (CKD); and (3) East Kamchatka (EK), at distances of 400,310, and $250 \mathrm{~km}$ from the trench, respectively. Some consider EK to comprise a northern and southern portions (Fedotov and Masurenkov, 1991). The most active island arc volcano in the world (Klyuchevskoy) is currently located within the CKD (Kersting and Arculus, 1994), together with a number of other highly explosive volcanoes. From north to south, these are Sheveluch, Klyuchevskoy, Bezymianny, and Tolbachik. The plinian eruption plume of the September-October 1994 eruption of Klyuchevskoy was witnessed by Space Shuttle astronauts to extend $>2000 \mathrm{~km}$ to the southeast of the volcano.

The Kamchatka Peninsula is an amalgamation of accreted continental fragments, island arcs, and obducted oceanic crust including seamounts, which range from Jurassic to Cretaceous in age (Watson and Fujita, 1985). It appears that accretion began about $150 \mathrm{Ma}$ ago in the western part of the peninsula, with the eastern side being the latest addition during the Miocene (Fedorchuk et al., 1993). The western part of Kamchatka is the eastern margin of the continental microplate of the Okhotsk block (Jolivet et al., 1988), which started to collide with Eurasia in the Late Jurassic. Closure continued until the Late Cretaceous.

Shantser and Shapiro (1988) proposed a detailed temporal development of Kurile-Kamchatka volcanism. Two main stages of evolution of volcanism are identified: the first stage commenced in the Late Cretaceous to the very beginning of the Paleocene ( 70 to $\sim 65 \mathrm{Ma})$, with volcanism exclusively in a submarine environment. The second stage commenced in the Paleocene and was dominated by subaerial volcanism. Three phases are identified in the second stage: (1) Paleocene-Eocene (63.5 to $\sim 36.5 \mathrm{Ma}$ ): subaerial volcanism occurred in the West Kamchatka Trough, to the west of the SR (Moroz, 1988; Gnibidenko et al., 1972). This region is also known as the western Kamchatka alkaline province (Erlich, 1971). (2) Oligocene-Miocene (36.5 to $\sim 5 \mathrm{Ma}$ ): subaerial volcanism was located in the present-day SR and South Kamchatka. Moroz (1988) argued that both of these belts form a continuous volcano-tectonic structure called the Kamchatka-Koryakskii anticlinorium. (3) Pliocene (5.1 to 1.8 Ma): all of the modern subaerial volcanic belts were fully developed during this period, with a predominance of low- and medium-K series lavas.

Ash distribution and composition of some of the largest (plinian) Holocene eruptions were reported by Kir'yanov and Rozhkov (1990) and Kir'yanov et al. (1990). Airfall deposits are traceable over tens of thousands of square kilometers and several are known to have travelled toward the region of the Detroit Seamount, including, for example, the $7.7 \mathrm{ka}$ caldera-forming Karymskii eruption and the $1.45 \mathrm{ka}$ eruption of Opala. Bulk compositions of these major Holocene eruptions are generally andesite-dacite.

Lithological characteristics and bulk major element and selected trace element analyses of ash layers recovered at Site 192 (Fig. 1) have been reported by Creager, Scholl, et al. (1973) and Scheidegger et al. (1980) respectively. From 0 to 140 meters below seafloor (mbsf), which is equivalent in age to the late Pliocene, the abundant ash layers range up to $30 \mathrm{~cm}$ in thickness, and are composed of colorless to light brown glass and microlites of feldspar, pyroxene, and oxide minerals. Compositions range from dacite to rhyolite, with the majority of medium-K character, but a minority are high-K. 


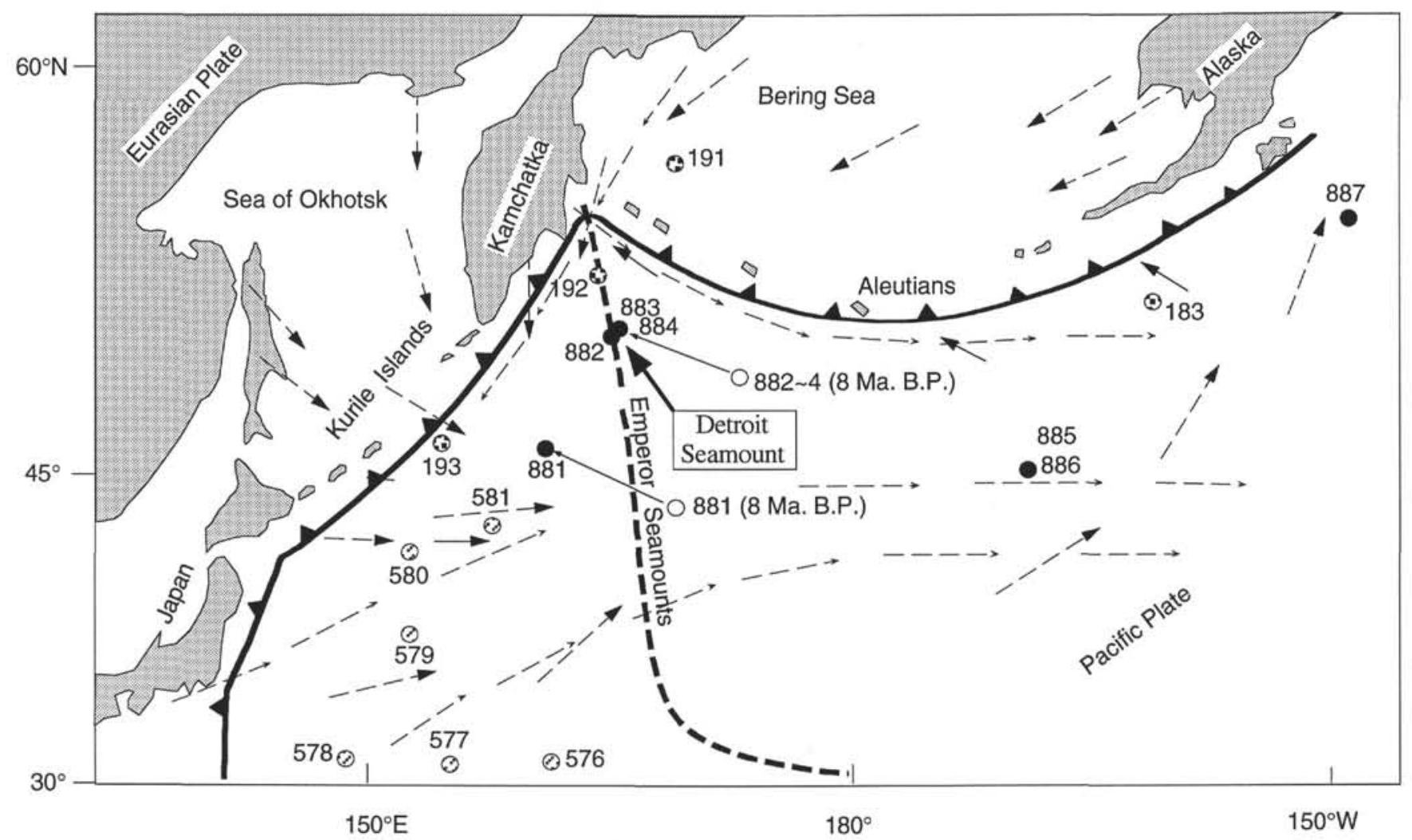

Figure 1. Map of the northwestern Pacific showing the locations of DSDP Legs 19 (Sites 183, 191-193) and 86 (Sites 576-581) and ODP Leg 145 Sites (solid circles). Other notations are the winter wind directions (dashed lines with large arrow heads), current directions (dashed lines with small arrow heads), direction of plate motion (solid line and arrow head), and reconstructed positions (arrow from open circles to present location) of Leg 145 Sites 881-884 for the past 8 m.y.

\section{ANALYTICAL PROCEDURES}

At the University of New England (UNE), all the samples were examined under a petrographic microscope to determine the morphologies and sizes of the shards, noting in particular all samples containing a sufficient number large enough to analyze (at least $10 \mathrm{~mm}$ in diameter), and any significant organic and clay contamination. Ash samples were carefully washed with distilled water and dried at $105^{\circ} \mathrm{C}$, affixed in an epoxy mounting ring, polished, and carbon coated.

The major element chemical composition of each vitric shard was obtained at UNE using a JEOL Model JSM35 electron microprobe with a KEVEX Si-Li energy dispersive spectrometer (EDS). Nine elements ( $\mathrm{Si}, \mathrm{Ti}, \mathrm{Al}, \mathrm{Fe}, \mathrm{Mn}, \mathrm{Mg}, \mathrm{Ca}, \mathrm{K}$, and $\mathrm{Na}$ ) were analyzed. Standard natural and synthetic glasses from the Smithsonian Institution were analyzed concurrently with excellent agreement between our analyses and the published values. Our experience with the UNE EMP is that the precision of multiple analyses of homogeneous glass standards produces concentration values within the expected range of $\mathrm{X}$-ray counting statistics, and is a function of elemental abundance and counting time. Comparisons of analyses obtained with this instrument and a wavelength-dispersive (WDS) EMP (Camebax) at the University of Michigan (UM) and the Australian National University are generally excellent, although we prefer the EDS system because it minimizes sample damage in hydrous, $\mathrm{SiO}_{2}$-rich glasses. For example, a comparison of the Na concentrations obtained by Arculus and Bloomfield (1992) for the ODP Leg 125 Izu-Bonin vitric shards using the EMP at UM, with values obtained at UNE, show significant differences involving up to $50 \%$ loss with the higher beam currents employed during WDS analysis. This loss occurred despite the use of a defocused and rastered beam spot. Operating conditions at UNE were $15 \mathrm{kV}$ accelerating voltage, $10 \mathrm{nA}$ beam current, and $100 \mathrm{~s}$ count time.

Many of the major element analyses total $<100 \%$. We believe this results from variable degrees of hydration of the glasses because totals close to the nominal $100 \%$ were obtained concurrently with the essentially anhydrous Smithsonian glass standards. We did not detect any consistent correlations between the abundances of potential additions through seawater of major elements such as $\mathrm{K}$ or trace elements such as $\mathrm{Sr}$, and the degree of apparent hydration (difference between the analytical total and $100 \%$ ) of the glasses.

A subset of 100 samples was analyzed by ICP-MS at Monash University. Because of time limitations, we chose to study layers initially from the southern (881) and one of the Detroit Seamount Sites (882). With the ICP-MS technique, we obtained abundances for $\sim 36$ trace elements, including the rare earth elements (REE). We routinely ran a number of standard rocks as unknowns with generally excellent agreement with the accepted values. Data for the transition elements, however, such as $\mathrm{Sc}, \mathrm{V}, \mathrm{Cr}, \mathrm{Co}$, and $\mathrm{Ni}$, seem to be less reliable by the ICP-MS technique given the relatively poor reproducibility observed.

Sample preparation involved digestion of $0.1 \pm 0.03 \mathrm{~g}$ of distilled water-washed ash sample for 24 to 48 hours in screw-top Teflon bombs at $100^{\circ}-120^{\circ} \mathrm{C}$ in a mixture of distilled $\mathrm{HF}(4 \mathrm{~mL})$ and distilled $\mathrm{HNO}_{3}(2 \mathrm{~mL})$. Sample solutions were slowly dried with heatlamps, and converted from fluorides to nitrates with additions of concentrated $\mathrm{HNO}_{3}$. Samples were then taken into solution with $50 \mathrm{~g}$ of $2 \%$ $\mathrm{HNO}_{3}$ (made from sub-boiled, distilled concentrated $\mathrm{HNO}_{3}$ and 18.2 $\mathrm{M} \Omega$ Millipore $\mathrm{H}_{2} \mathrm{O}$ ). Aliquots of this solution were run at a total dilution factor of $\approx 2000$. All samples were made up with $100 \mathrm{ppb}$ In to serve as an internal standard for drift correction. One analytical blank and 5 standard solutions (based on U.S. Geological Survey standard rocks) were typically prepared for each run. An initial calibration was performed using synthetic standards and finalized with a set of laboratory and international standards. Total analytical blanks are typically $<20 \mathrm{ppb}$ for most elements except for $\mathrm{Sc}, \mathrm{Cr}, \mathrm{Cu}$ and $\mathrm{Ni}$ (which are $<500 \mathrm{ppb}$ ). Errors are $\pm 15-20$ relative \% for $\mathrm{Sc}, \mathrm{Ga}$, $\mathrm{Ge}, \mathrm{Pr}, \mathrm{Gd}, \mathrm{Th}$, and $\mathrm{U}$ depending on abundances, $\pm 5-10$ relative 
$\%$ for the other REE and $\pm 3-15$ relative \% for all other trace elements analyzed.

Prior to separation of the $\mathrm{Sr}$ and $\mathrm{Nd}$ fractions for isotopic studies, we employed a relatively mild leaching process with $\mathrm{HCl}$ that we found was effective in returning consistent isotopic ratios without any sign of seawater contamination for glass shards from Legs 60 and 125 (W. Chen and R.J. Arculus, unpubl. data). The success of this procedure implies some addition of seawater $\mathrm{Sr}$ to the glasses, but at this stage we have not quantified the effect. Subsequently, we used standard techniques with ion-exchange separation columns for $\mathrm{Sr}$ and $\mathrm{Nd}$ at UNE, followed by thermal ionization mass spectrometry (VG 354 spectrometer) for $\mathrm{Sr}$ and $\mathrm{Nd}$ isotope ratios at the Center for Isotope Studies at North Ryde in Sydney. Reference standards throughout the course of analysis averaged values of ${ }^{87} \mathrm{Sr} /{ }^{86} \mathrm{Sr}=0.71027 \pm 1$ for NBS 987 , and ${ }^{143} \mathrm{Nd} /{ }^{144} \mathrm{Nd}=0.511111 \pm 10$ for the O'Nions Nd standard. The ${ }^{87} \mathrm{Sr} /{ }^{86} \mathrm{Sr}$ was normalized to ${ }^{86} \mathrm{Sr} /{ }^{88} \mathrm{Sr}=0.1194,{ }^{143} \mathrm{Nd} /{ }^{144} \mathrm{Nd}$ was normalized to ${ }^{146} \mathrm{Nd} /{ }^{144} \mathrm{Nd}=0.7219$, and $\varepsilon_{\mathrm{Nd}}$ values were calculated assuming an average chondritic value of ${ }^{143} \mathrm{Nd} /{ }^{144} \mathrm{Nd}$ at present of 0.512638 .

\section{STRATIGRAPHY AND LITHOLOGY}

The majority of the ash layers occur within the predominantly upper Miocene to Pleistocene clayey diatom ooze of the northwest Pacific (Fig. 2; Tables 1, 2, 3, and 4). Ages were estimated based on the stratigraphic positions of radiolarian and diatom datum levels in the vicinity of the ash layers provided by the Leg 145 Shipboard Scientific Party (Rea, Basov, Janecek, Palmer-Julson, et al., 1993). The most detailed estimation of the age of each ash layer was completed by interpolations assuming linear sedimentation rates in the different depth ranges; thus, the exact age (the accuracy is limited to $0.01 \mathrm{Ma}$ ) may not be reliable for fine stratigraphic dating, but it is still considered accurate enough to provide general correlations for each ash layer.

For Site 884 (Fig. 2D), it appears from the number and thickness of ash layers that there are pulses of increased explosive activity: 0.0 to $\sim 0.2,0.3$ to $\sim 0.4,0.8$ to $\sim 1.0$, and 1.5 to $\sim 1.8$ Ma during the Pliocene-Pleistocene-Holocene. Not all of these pulses of activity are obvious in the recovery at Sites 882 (Fig 2B) and 883 (Fig. 2C), but do appear at Site 881 (Fig. 2A) with an additional pulse at 2.4 to $\sim 2.6$ $\mathrm{Ma}$. Within any given pulse, the volcanic ashes are characterized by a wide compositional spectrum from basaltic andesite to rhyolite (Fig. 3 ), a wide range of potassium abundances (Fig. 4), and a wide range of $\mathrm{La} / \mathrm{Y}$ ratios (Fig. 5). It is notable that these pulses of volcanism during the Pleistocene and Pliocene are also recognized in the Japan arc system (Pouclet and Scott, 1992).

A marked paucity of ash layers is noted during the period of 6.3 to $\sim 34.4 \mathrm{Ma}$, but partly to completely altered ashes, now seen as yellow palagonite and smectite, reappear below lower Oligocene to middle Eocene nannofossil chalks and claystone (34.4-45 Ma), much of which is reworked and slumped (Rea, Basov, Janecek, Palmer-Julson, et al., 1993). There is a distinct difference in compositional mode between the ash layers younger than $6.3 \mathrm{Ma}$ and those older than 34.4 $\mathrm{Ma}$. The former are dominated by rhyolite while the latter are predominantly basaltic andesite.

Several remarkably thick ash layers are present at Sites 881 through 884. All of these huge ash layers are rhyolite in composition, light gray in color (dry sample), and characterized by sharply pointed, fragile, elongate vitric shards, which are consistent with air fall rather than pumice rafting. The thick layers are present as follows: (1) $110 \mathrm{~cm}$ thick between Sections $145-881 \mathrm{~A}-1 \mathrm{H}-4$ and -5 , but curiously thinned or patchily represented in Holes $881 \mathrm{~B}$ and $881 \mathrm{C}$; (2) $130 \mathrm{~cm}$ thick in Section 145-884B-6H-2; (3) 40 cm thick in Section 145-884B-7H-2; (4) $50 \mathrm{~cm}$ thick in Section 145-884B-8H-7; (5) $180 \mathrm{~cm}$ thick between Sections 145-884B-9H-5 and -7; (6) $120 \mathrm{~cm}$ thick between sections 145-884B-9H-7 and 145-884B-10H-1; (7) $250 \mathrm{~cm}$ thick between Sections $145-884$ C- $6 \mathrm{H}-4$ and -5 ; (8) $140 \mathrm{~cm}$ thick between Sections $145-$
$884 \mathrm{C}-9 \mathrm{H}-3$ and -4 . Shipboard correlations between different holes were successful for Site 881 but not reported for Sites 882, 883, and 884 , and, at present, we do not have sufficient chemical data to identify correlations within and among the different holes at these sites.

The correlation of distance of transport of tephra from an eruption source with physical parameters such as mean and maximum shard diameters and crystal/glass modal proportions have been well documented (Sparks and Walker, 1977; Walker, 1980; Carey and Sigurdsson, 1980; Kyle et al., 1981; Rose and Chesner, 1987). The mean diameters of vitric shards from Sites 881 through 884 are all $\sim 30 \mu \mathrm{m}$ (phi value $=5$ ), implying a source distance $>500 \mathrm{~km}$ (Rose and Chesner, 1987).

Two color assignments were made for the ashes. The first, for all of the layers, was recorded by the Leg 145 Shipboard Scientific Party, who estimated the color for wet samples, possibly with variable modulation by clay and ooze. In detail, the determination was variably made with the standard Munsell notation or more qualitatively (Rea, Basov, Janecek, Palmer-Julson, et al., 1993). Another set of colors, recorded by the authors for the restricted sample set, is assigned to dried, clayfree ash samples that had been carefully washed with distilled water. The revised standard soil color charts of Oyama and Takehara (1967), equivalent to Munsell, were used. It is interesting to note that all dry ash samples are characterized by the gray-dominated hue $2.5 \mathrm{Y}$ with no exception, although the wet (possible clay- and ooze-admixed) sample color varies considerably. We note a good correlation exists between ash composition and color: all rhyolites are light gray in color (hue $2.5 \mathrm{Y}$, value 7 or 8 , chroma 1 or 2 ) or grayish yellow (hue $2.5 \mathrm{Y}$, value 7 , chroma 2); dacite-rhyolite (mixtures of the two compositions) are yellowish gray (hue $2.5 \mathrm{Y}$, value 6 , chroma 1 ); most andesite-dacite (mixtures of the two compositions) are yellowish gray (hue 2.5, value 4,5 , and 6 , chroma 1); and basaltic andesites are yellowish gray (hue 2.5 Y, value 3,4 , and 5 , chroma 1 or 2 ).

\section{GEOCHEMISTRY}

\section{Major Element Geochemistry}

About 2000 major element analyses of vitric shards were obtained by EMP-EDS (Tables 5, 6, 7, and 8). In general, a single analysis of an individual shard was made because of the relatively small sizes involved. Although the compositional spectrum ranges from basaltic andesite to rhyolite, the latter are volumetrically predominant (Fig. 4A). Low-, medium-, and high-K series are identified based on Gill's (1981) classification boundaries (Fig. 4B). On the basis of Miyashiro's (1974) criterion, the overwhelming majority of these are tholeiitic (Fig. 4C). We note a general coincidence of occurrence of compositional types between the southern (881) and northern (882-883-884) sites. Low-K rhyolites do, however, occur predominantly at Site 881 with only sparse representation at the Detroit Seamount sites. In view of the somewhat random sampling technique employed for the ash layers at Sites 882 through 884 , it is encouraging that the same compositional groupings appear for all of these Sites. We assume as a result that the sampling strategy has successfully recovered the full range of compositions that exist within the ash population.

In Figure 3 are presented some aspects of the variations of major element geochemistry of the Neogene ashes as a function of time for Sites 881 through 884 . A number of observations can be made with respect to these data:

1. Recognizing the likelihood of a variable geographic source of these ashes, there is no regularity in the development of more alkaline (for example, higher $\mathrm{K}$ ) compositions with the passage of time;

2. In fact, high- $K$ compositions appear at various times in the combined temporal record including a prominent pulse at about $6 \sim$ 7.5 Ma;

3. Recalling that the sampling effort was designed originally for comprehensive coverage but not specifically for correlative purposes, we note that a comparison of the compositional variations between 0 
and 3.5 Ma of ashes recovered from Sites 881 and 882 show a number of similarities including a period of explosive quiescence between 1.5 and $1.1 \mathrm{Ma}$ and a general similarity of compositional fluctuations, possibly indicative of fallout from the Kurile-Kamchatka system generally reaching both the southern and northern sites.

In the framework of the global correlation of Plank and Langmuir (1988) of levels of $\mathrm{wt} \% \mathrm{CaO}$ at specific $\mathrm{MgO}$ content as a function of arc crustal thickness, we show the relevant data in Figure 6. First, we note no obvious spread of values as a function of time, and, second, a crustal thickness of about $12-15 \mathrm{~km}$ would be inferred for the sources of the ashes.

\section{Trace Element Geochemistry}

Trace element abundances were determined by ICP-MS for about 100 ash samples, primarily from Sites 881 and 882 (Tables 9 and 10), and for Paleogene ashes from Sites 883 and 884 (Table 11). A considerable range in abundances of elements such as the REE at any given wt $\% \mathrm{SiO}_{2}$ are present. Within the rhyolites, there is generally a positive correlation between $\mathrm{K}$ content and the degree of light REE enrichment. A variety of REE fractionations is present in these ashes from light REE-depleted through relatively unfractionated to light REE-enriched, and 12 groups ( $A$ to $\mathrm{L}$ ) are recognized on the basis of the similarities of these fractionations in combination with other trace element variations (Fig. 7). Negative Eu anomalies of varying magnitude developed in the majority of the groups are indicative of feldspar fractionation, and in most of the dacite and rhyolite compositions, a concave-upward pattern between $\mathrm{Gd}$ and $\mathrm{Lu}$ is developed. This style of medium-to-heavy REE fractionation is characteristic of the fractional crystallization of amphibole, or the persistence of residual amphibole in a source rock if these felsic rocks represent crustal partial melts. We discern no temporal consistency in terms of REE fractionations (Fig. 5).

In Figure 8, we contrast the variations of a range of trace elements (of contrasted crystal-melt distribution coefficients) within these ash groups. Taking a distinctive group of upper Miocene, high-K, light REE-enriched ashes as a normalizing group (UNE layer numbers 81 to 86 ), a number of prominent element abundance fractionations and ratios are apparent. Published accounts of subaerial explosive volcanism present in Kamchatka in the upper Miocene (Fedotov and Masurenkov, 1991) indicate the most probable source of this particular group of high-K ashes was the alkaline (including absarokiteshoshonite) volcanism in the SR.

In addition to the fractionation of the REE apparent in Figure 7 , abundances of highly incompatible large ion lithophile trace elements such as $\mathrm{Rb}, \mathrm{Ba}$, and Th vary by an order of magnitude relative to these high- $\mathrm{K}$ ashes. In addition, $\mathrm{Rb} / \mathrm{Ba}$ and $\mathrm{Th} / \mathrm{U}$ ratios range from values strongly less than to more than those of the high-K ashes $(\sim 0.17$ and 2.5 , respectively). The high-K Miocene ashes are also characterized by distinctively lower $\mathrm{Nb} / \mathrm{Ta}$ than the majority of the ashes (Fig. 9). We are in the process of compiling a geochemical data base for comparison of the ash groups with the five, major subaerial volcanic belts of the Kurile-Kamchatka arc system (Kurile Islands, South Kamchatka, EK, CKD and SR). The apparent presence of some geographically diagnostic and temporally persistent trace element fractionations may allow assignment of specific ash layers to sources in the arc.

The ${ }^{143} \mathrm{Nd} /{ }^{144} \mathrm{Nd}$ vs. ${ }^{87} \mathrm{Sr} /{ }^{86} \mathrm{Sr}$ values for selected ash layers from Sites 881 and 882 are listed in Tables 9 and 10 and displayed in Figure 10. Most of the samples overlap the range we have obtained for active volcanoes in the CKD and EK, and values reported for the Kuriles by Zhuravlev et al. (1985) with $\varepsilon_{\mathrm{Nd}} \sim+8$ and ${ }^{87} \mathrm{Sr} /{ }^{86} \mathrm{Sr}=0.7031$ to 0.7038 , but some samples range to lower $\varepsilon_{\mathrm{Nd}}$ of +3 and ${ }^{87} \mathrm{Sr} /{ }^{86} \mathrm{Sr}$ of $\sim 0.7045$. Furthermore, many of the highly explosive and active volcanoes of the CKD and the Kurile arc are currently characterized by distinctly higher $\varepsilon_{\mathrm{Nd}}(+9$ to 10$)$ than the ashes, which is perhaps indicative of the general insignificance of the CKD as a major source of the offshore ashes sampled to date.

Chondrite-normalized REE abundances for the Paleogene ashes recovered from the base of the sedimentary sections in Holes $883 \mathrm{~B}$ and 884B, are shown in Figure 11. Given the extensive alteration of these materials, it is not clear to what extent the pristine igneous geochemistry can be recovered. However, the relatively unfractionated patterns with slight negative Eu anomalies are similar to the ejecta of many of the active volcanoes of the Izu-Bonin-Mariana and Kurile arcs of the western Pacific. The high $\mathrm{Ba} / \mathrm{Nb}(>200), \mathrm{Sc} / \mathrm{Ga}$ $(>1)$, and low $\mathrm{TiO}_{2}$ of these basaltic and andesitic ashes are consistent with derivation from an arc rather than mid-ocean ridge basalt (MORB) or ocean island (hot spot) source. The negative $\mathrm{Ce}$ anomalies of these ashes may be the result of seawater alteration.

\section{MINERALOGY \\ Plagioclase}

Feldspar microlites were analyzed where present in each ash layer (Tables 12 and 13). A ternary plot (Fig. 12) of albite, anorthite, and orthoclase shows a continuum of plagioclase compositions from $\sim \mathrm{An}_{96}$ to $\mathrm{An}_{38}$ with $<\mathrm{Or}_{5}$ mole \%. We are surprised by the absence of potassium feldspar given the prominent occurrences of high-K rhyolitic compositions. It is possible that selective winnowing of different mineral fragments has occurred, but a renewed search of the microlites in Site 192 ashes may prove instructive in this regard in view of the relative proximity of this site to Kamchatka.

\section{Fe-Ti Oxides}

A total of 120 iron-titanium oxide microlites was analyzed from 46 ash layers recovered from Sites $881,882,883$, and 884 . Of these, 23 were identified as a rhombohedral phase and the rest were recognized as spinels. Twelve magnetite-ilmenite pairs were found coexisting with vitric shards ranging from basaltic-andesite to rhyolite. Analyses of the iron-titanium oxides are presented in Table 14. The ferric and ferrous iron contents are calculated by an approach modified from Carmichael (1967). In order to calculate temperature and oxygen fugacity $\left(\mathrm{fO}_{2}\right)$ with the Fe-Ti oxide geothermometer/oxygen barometer developed by Ghiorso and Sack (1991), we assume that each ash layer originated from a single source, and the average compositions of the different ilmenite and magnetite pairs are utilized to derive $\mathrm{T}-f \mathrm{O}_{2}$ data. The values are close to the synthetic fayalitemagnetite-quartz (FMQ $\pm 0.5 \log _{10}$ units) buffer in the range $850^{\circ}-$ $1100^{\circ} \mathrm{C}$. This is, in fact, relatively reduced compared with the majority of island arcs (Ballhaus, 1993).

\section{Clinopyroxene and Amphibole}

Clinopyroxene microlites are present in ash layers of a wide compositional spectrum but are more common in basaltic andesite to dacite. Most clinopyroxene (Table 15) is in the $\mathrm{Wo}_{40} \mathrm{En}_{45} \mathrm{Fs}_{15} \sim$ $\mathrm{Wo}_{30} \mathrm{En}_{55} \mathrm{Fs}_{25}$ range, with a single microlite of $\mathrm{Wo}_{17} \mathrm{En}_{53} \mathrm{Fs}_{30}$. Pargasitic amphibole occurs rarely as a microlitic phase, so far discovered only at Site 881 .

\section{DISCUSSION}

On the basis of results obtained from geochemical and petrological study of the ash layers from Sites 881 to 884 , we can attempt some qualified response to the questions relating to subduction zone petrogenesis posed in the introduction to this paper. For example, it is clear both from this study as well as others pursued recently on the explosive products of the Izu-Bonin-Mariana (IBM) system, that the temporal changes in the eruptive products of island arcs that occur are not in a monotonic sense of increasing alkalinity with time (Gill et al., 1994; Arculus et al., 1995). In fact, in the case of the Kurile- 
Table 1. Stratigraphic and lithological characteristics of volcanic ash layers from Site $\mathbf{8 8 1}$.

\begin{tabular}{|c|c|c|c|c|c|c|c|c|c|}
\hline $\begin{array}{l}\text { UNE } \\
\text { number }\end{array}$ & $\begin{array}{c}\text { Group } \\
\text { number }\end{array}$ & $\begin{array}{l}\text { Age } \\
\text { (Ma) }\end{array}$ & $\begin{array}{l}\text { Depth } \\
\text { (mbsf) }\end{array}$ & $\begin{array}{l}\text { Thickness } \\
(\mathrm{cm})\end{array}$ & $\begin{array}{l}\text { Size of vitric shard } \\
(0.01 \mathrm{~mm})\end{array}$ & $\begin{array}{c}\text { Color } \\
\text { (dry sample) }\end{array}$ & $\begin{array}{c}\text { Color } \\
\text { (shipboard estimate) }\end{array}$ & Composition & Lithology \\
\hline \multicolumn{10}{|l|}{ Hole 881A } \\
\hline & d & & 6.8 & & $1 \times 10$ & Light gray (2.5Y 8/2) & $5 \mathrm{Y}, 10 \mathrm{Y}$, and $10 \mathrm{YR}$ & Rhyolite & Diatom ooze and volcanic ash \\
\hline \multirow{6}{*}{2} & & & 7.9 & & & & $5 \mathrm{Y}, 10 \mathrm{Y}$, and $10 \mathrm{YR}$ & & Diatom ooze and volcanic ash \\
\hline & b & & 9.2 & $110(3 \sim 6)$ & $2 \times 2$ & Light gray $(2.5 Y 8 / 1)$ & $5 \mathrm{Y}, 10 \mathrm{Y}$, and $10 \mathrm{YR}$ & Rhyolite & Diatom ooze and volcanic ash \\
\hline & 0 & & 9.5 & $110(3 \sim 6)$ & 202 & 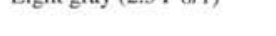 & $5 \mathrm{Y}, 10 \mathrm{Y}$, and $10 \mathrm{YR}$ & - & Diatom ooze and volcanic ash \\
\hline & & & 9.8 & $110(3 \sim 6)$ & & & $5 \mathrm{Y}, 10 \mathrm{Y}$, and $10 \mathrm{YR}$ & - & Diatom ooze and volcanic ash \\
\hline & & & 10.1 & $110(3 \sim 6)$ & & & $5 \mathrm{Y}, 10 \mathrm{Y}$, and $10 \mathrm{YR}$ & - & Diatom ooze and volcanic ash \\
\hline & & & 10.6 & - & & & $5 Y, 10 Y$, and $10 Y R$ & - & Diatom ooze and volcanic ash \\
\hline 3 & d & & 12.1 & $\overline{00}$ & $5 \times 0$ & Light gray $(2.5 \mathrm{Y} 8 / 1)$ & $5 \mathrm{Y}, 10 \mathrm{Y}$, and $10 \mathrm{YR}$ & Rhyolite & Diatom ooze and volcanic ash \\
\hline 4 & & & 12.5 & 30 & $1 \times 3$ & Light gray $(2.5 Y 8 / 1)$ & $5 \mathrm{Y}, 10 \mathrm{Y}$, and $10 \mathrm{YR}$ & Rhyolite & Diatom ooze and volcanic ash \\
\hline \multicolumn{10}{|l|}{ Hole $881 \mathrm{~B}$} \\
\hline & & 0.33 & 8.7 & - & & & - & - & Diatom ooze with quartz silt \\
\hline & & 0.34 & 8.9 & - & & & - & - & Diatom ooze with quartz silt \\
\hline 7 & & 0.35 & 12.6 & - & $1 \times 5$ & Light gray $(2.5 Y 8 / 1)$ & - & Rhyolite & Diatom ooze with quartz silt \\
\hline & & 0.36 & 13.2 & - & & & - & & Diatom ooze with quartz silt \\
\hline 8 & & 0.38 & 15.5 & - & $1 \times 8$ & Light gray $(2.5 \mathrm{Y} 7 / 1)$ & - & Rhyolite & Diatom ooze \\
\hline & & 0.40 & 18.6 & - & & & - & & Diatom ooze \\
\hline 10 & $\mathrm{~g}$ & 0.45 & 22.4 & - & $1 \times 3$ & Light gray (2.5Y $7 / 1)$ & - & Rhyolite & Diatom ooze \\
\hline \multirow{5}{*}{12} & $\mathrm{~b}$ & 0.46 & 23.9 & - & $1 \times 5$ & Light gray $(2.5 \mathrm{Y} 8 / 1)$ & - & Rhyolite & Diatom ooze \\
\hline & b & 0.49 & 25.8 & - & $1 \times 3$ & Light gray $(2.5 \mathrm{Y} 8 / 2)$ & - & Rhyolite & Diatom ooze \\
\hline & & 0.51 & 26.2 & - & & & - & - & Diatom ooze \\
\hline & & 0.53 & 29.6 & - & & & - & - & Diatom ooze \\
\hline & & 0.57 & 35.1 & - & & & (3.2GY 3.1/1.3) - & $\overline{\mathrm{n}}$ & Ashy diatom ooze \\
\hline \multirow[t]{7}{*}{13} & $\mathrm{j}$ & 0.63 & 38.1 & - & $4 \times 8$ & Grayish yellow $(2.5 Y 7 / 2)$ & (5.5YR 3.2/0.8) & Basaltic andesite & Ashy diatom ooze \\
\hline & & 0.65 & 39.3 & - & & & $(3.2 \mathrm{GY} 3.1 / 1.3)-$ & - & Ashy diatom ooze \\
\hline & & 0.66 & 41.0 & - & & & $(5.5 Y R \quad 3.2 / 0.8)$ & - & Ashy diatom ooze \\
\hline & & 0.67 & 41.2 & - & & & (3.2GY 3.1/1.3)- & - & Ashy diatom ooze \\
\hline & & 0.68 & 42.6 & - & & & (5.5YR $3.2 / 0.8)$ & - & Ashy diatom ooze \\
\hline & & 0.69 & 42.9 & - & & & (3.2GY 3.1/1.3) (5.5YR 3.2/0.8) & - & Ashy diatom ooze \\
\hline & & 0.70 & 44.3 & - & & & $(9 \mathrm{GYY} 1.3 / 1.9) \sim(2.5 Y 5.0 / 1.0)$ & $=$ & Ashy diatom clay to diatom clay \\
\hline 14 & $\mathrm{e}$ & 0.71 & 45.7 & - & $0.5 \times 5$ & Yellowish gray $(2.5 \mathrm{Y} 6 / 1)$ & (9GY 1.3/1.9) (2.5Y 5.0/1.0) & Andesite-dacite & Ashy diatom clay to diatom clay \\
\hline 15 & c & 0.73 & 46.9 & $\bar{z}$ & $1 \times 3$ & Grayish yellow $(2.5 \mathrm{Y} 7 / 2)$ & $(9 \mathrm{GY} 1.3 / 1.9) \sim(2.5 \mathrm{Y} 5.0 / 1.0)$ & Rhyolite & Ashy diatom clay to diatom clay \\
\hline \multirow[t]{6}{*}{16} & $\mathrm{k}$ & 0.76 & 51.3 & - & $1 \times 5$ & Light gray $(2.5 Y 8 / 1)$ & $(9 \mathrm{GY} 1.3 / 1.9) \sim(2.5 \mathrm{Y} 5.0 / 1.0)$ & Rhyolite & Ashy diatom clay to diatom clay \\
\hline & & 0.78 & 53.2 & - & & & $(5.3 \mathrm{Y} 3.5 / 1.1)$ & & Ashy diatom clay to ashy diatom ooze \\
\hline & & 0.80 & 56.8 & - & & & $(5.3 \times 3.5 / 1.1)$ & - & Ashy diatom clay to ashy diatom ooze \\
\hline & & 0.82 & 59.0 & - & & & $(5.3 Y 3.5 / 1.1)$ & - & Ashy diatom clay to ashy diatom ooze \\
\hline & & 0.83 & 59.2 & - & & & $(5.3 Y 3.5 / 1.1)$ & - & Ashy diatom clay to ashy diatom ooze \\
\hline & & 0.85 & 59.8 & - & & & $(5.3 Y 3.5 / 1.1)$ & $\bar{a}$ & Ashy diatom clay to ashy diatom ooze \\
\hline \multirow[t]{4}{*}{17} & a & 0.87 & 60.2 & - & $2 \times 4$ & Light gray $(2.5 Y 8 / 1)$ & $(5.3 Y 3.5 / 1.1)$ & Rhyolite & Ashy diatom clay to ashy diatom ooze \\
\hline & & 0.88 & 60.6 & - & & & $(5.3 \mathrm{Y} 3.5 / 1.1)$ & - & Ashy diatom clay to ashy diatom ooze \\
\hline & & 0.88 & 60.8 & - & & & (5.3Y $3.5 / 1.1)$ & - & Ashy diatom clay to ashy diatom ooze \\
\hline & & 0.89 & 61.2 & - & & & (5.3Y $3.5 / 1.1)$ & - & Ashy diatom clay to ashy diatom ooze \\
\hline \multirow[t]{8}{*}{18} & a & 0.89 & 61.5 & - & $3 \times 5$ & Light gray $(2.5 \mathrm{Y} 8 / 1)$ & (5.3Y $3.5 / 1.1)$ & Rhyolite & Ashy diatom clay to ashy diatom ooze \\
\hline & a & 0.89 & 61.8 & $\overline{-}$ & $3 \times 5$ & Lignt gray $(2.0 / 8 / 1)$ & (5.3Y 3.5/1.1) & - & Ashy diatom clay to ashy diatom ooze \\
\hline & & 0.91 & 62.1 & - & & & $(5.3 \mathrm{Y} 3.5 / 1.1)$ & - & Ashy diatom clay to ashy diatom ooze \\
\hline & & 0.95 & 64.5 & - & & & $(6.5 Y 4.2 / 1.0)$ & - & Clayey diatom ooze \\
\hline & & 0.96 & 64.9 & - & & & $(6.5 Y 4.2 / 1.0)$ & - & Clayey diatom ooze \\
\hline & & 0.96 & 65.2 & - & & & $(6.5 Y 4.2 / 1.0)$ & - & Clayey diatom ooze \\
\hline & & 0.99 & 69.1 & - & & & $(6.5 Y 4.2 / 1.0)$ & - & Clayey diatom ooze \\
\hline & & 1.00 & 71.0 & - & & & $(6.5 Y 4.2 / 1.0)$ & & Clayey diatom ooze \\
\hline \multirow[t]{15}{*}{19} & a & 1.01 & 72.5 & - & & Light gray $(2.5 \mathrm{Y} 8 / 1)$ & $(7.9$ YR $3.9 / 1.2) \sim(9.9$ YR $3.9 / 1.2)$ & Rhyolite & Clayey diatom ooze \\
\hline & & 1.03 & 73.0 & - & & & $(7.9 \mathrm{YR} 3.9 / 1.2) \sim(9.9 \mathrm{YR} 3.9 / 1.2)$ & & Clayey diatom ooze \\
\hline & & 1.04 & 73.4 & - & & & $(7.9 \mathrm{YR} 3.9 / 1.2) \sim(9.9 \mathrm{YR} 3.9 / 1.2)$ & - & Clayey diatom ooze \\
\hline & & 1.05 & 74.1 & - & & & (7.9YR 3.9/1.2) (9.9YR 3.9/1.2) & - & Clayey diatom ooze \\
\hline & & 1.11 & 77.1 & - & & & (7.9YR $3.9 / 1.2) \sim(9.9$ YR $3.9 / 1.2)$ & - & Clayey diatom ooze \\
\hline & & 1.12 & 77.3 & - & & & (7.9YR 3.9/1.2) (9.9YR 3.9/1.2) & - & Clayey diatom ooze \\
\hline & & 1.13 & 78.2 & $\overline{-}$ & & & (7.9YR 3.9/1.2) (9.9YR 3.9/1.2) & - & Clayey diatom ooze \\
\hline & & 1.14 & 79.3 & $\bar{z}$ & & & (7.9YR $3.9 / 1.2) \sim(9.9$ YR $3.9 / 1.2)$ & $\bar{z}$ & Clayey diatom ooze \\
\hline & & 1.15 & 79.7 & - & & & (7.9YR 3.9/1.2) (9.9YR 3.9/1.2) & - & Clayey diatom ooze \\
\hline & & 1.17 & 80.2 & $\overline{-}$ & & & (7.9YR 3.9/1.2) (9.9YR 3.9/1.2) & $=$ & Clayey diatom ooze \\
\hline & & 1.21 & 82.0 & - & & & (7) - & - & Diatom ooze with clay \\
\hline & & 1.22 & 82.2 & - & & & - & - & Diatom ooze with clay \\
\hline & & 1.23 & 82.8 & - & & & - & - & Diatom ooze with clay \\
\hline & & 1.23 & 83.2 & - & & & - & - & Diatom ooze with clay \\
\hline & & 1.24 & 83.8 & - & & & - & - & Diatom ooze with clay \\
\hline
\end{tabular}


Table 1 (continued).

\begin{tabular}{|c|c|c|c|c|c|c|c|c|c|}
\hline $\begin{array}{c}\text { UNE } \\
\text { number }\end{array}$ & $\begin{array}{c}\text { Group } \\
\text { number }\end{array}$ & $\begin{array}{l}\text { Age } \\
\text { (Ma) }\end{array}$ & $\begin{array}{l}\text { Depth } \\
\text { (mbsf) }\end{array}$ & $\begin{array}{l}\text { Thickness } \\
(\mathrm{cm})\end{array}$ & $\begin{array}{l}\text { Size of vitric shard } \\
\quad(0.01 \mathrm{~mm})\end{array}$ & $\begin{array}{c}\text { Color } \\
\text { (dry sample) }\end{array}$ & $\begin{array}{c}\text { Color } \\
\text { (shipboard estimate) }\end{array}$ & Composition & Lithology \\
\hline 20 & & 1.24 & 84.2 & - & $1 \times 6$ & Grayish yellow $(2.5 \mathrm{Y} 6 / 2)$ & - & - & Diatom ooze with clay \\
\hline \multirow{4}{*}{$21 \sim 24$} & \multirow{4}{*}{ f } & 1.34 & 85.9 & - & & & - & - & Diatom ooze with clay \\
\hline & & 1.45 & 90.1 & - & $1 \times 3$ & Light gray $(2.5 Y 7 / 1)$ & - & Andesite-dacite & Diatom ooze with clay \\
\hline & & 1.55 & 90.6 & - & & & - & - & Diatom ooze with clay \\
\hline & & 1.60 & 90.8 & - & & & - & - & Diatom ooze with clay \\
\hline \multirow{3}{*}{$\begin{array}{l}25 \\
26\end{array}$} & \multirow{3}{*}{ d } & 1.62 & 92.2 & - & $1 \times 10$ & Light gray $(2.5 Y 7 / 1)$ & & Rhyolite & Clayey diatom ooze \\
\hline & & 1.65 & 93.9 & - & $1 \times 8$ & Light gray $(2.5 Y 7 / 1)$ & $(5 Y 3 / 1)$ & & Clayey diatom ooze \\
\hline & & $\begin{array}{l}1.60 \\
1.68\end{array}$ & 94.6 & $=$ & $1 \times 8$ & 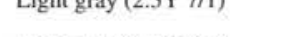 & $(5 \mathrm{Y} 3 / 1)$ & $\bar{z}$ & Clayey diatom ooze \\
\hline \multirow{5}{*}{$\begin{array}{l}27 \\
28\end{array}$} & \multirow{5}{*}{$\begin{array}{l}\mathrm{d} \\
\mathrm{k}\end{array}$} & 1.72 & 96.0 & - & $1 \times 5$ & Light gray $(2.5 Y 8 / 1)$ & \multirow{2}{*}{$\begin{array}{l}(5 \mathrm{Y} 3 / 1) \\
(5 \mathrm{Y} 3 / 1)\end{array}$} & Rhyolite & Clayey diatom ooze. \\
\hline & & 1.73 & 96.2 & 二 & $1 \times 3$ & Light gray $(2.5 \mathrm{Y} 8 / 1)$ & & Rhyolite & Clayey diatom ooze \\
\hline & & 1.79 & 98.2 & - & & & (5Y 3/1) & - & Clayey diatom ooze \\
\hline & & 1.81 & 98.6 & - & & & $\begin{array}{l}(5 \mathrm{Y} 3 / 1) \\
(5 \mathrm{Y} 3 / 1)\end{array}$ & - & Clayey diatom ooze \\
\hline & & 1.82 & 99.0 & - & & & $(5 \mathrm{Y} 3 / 1)$ & & Clayey diatom ooze \\
\hline 29,30 & $\mathrm{~g}$ & 1.84 & 101.1 & - & $1 \times 3$ & Light gray $(2.5 Y 7 / 1)$ & - & Rhyolite & Clayey diatom ooze \\
\hline 31 & \multirow{5}{*}{ b } & 1.87 & 101.8 & - & $0.5 \times 8$ & Light gray $(2.5 \mathrm{Y} 8 / 2)$ & - & Rhyolite & Clayey diatom ooze \\
\hline \multirow[t]{4}{*}{32} & & 1.90 & 102.2 & - & $3 \times 10$ & Light gray $(2.5 \mathrm{Y} 7 / 1)$ & - & Rhyolite & Clayey diatom ooze \\
\hline & & 1.92 & 103.8 & - & & & - & - & Clayey diatom ooze \\
\hline & & 1.94 & 104.3 & - & & & - & - & Clayey diatom ooze \\
\hline & & 1.98 & 110.0 & - & \multirow{5}{*}{$2 \times 4$} & & - & - & Clayey diatom ooze \\
\hline \multirow[t]{4}{*}{33} & & 2.07 & 112.7 & - & & \multirow{4}{*}{ Yellowish gray ( $2.5 \mathrm{Y} 4 / 1)$} & - & Andesite-rhyolite & Clayey diatom ooze \\
\hline & & 2.09 & 113.8 & $=$ & & & $\bar{z}$ & - & Clayey diatom ooze \\
\hline & & 2.10 & 114.1 & $=$ & & & $=$ & $\overline{-}$ & Clayey diatom ooze \\
\hline & & 2.11 & 115.8 & $=$ & & & $\bar{z}$ & $=$ & Clayey diatom ooze \\
\hline 34 & & 2.12 & 116.4 & - & $1 \times 5$ & Light gray $(2.5 Y 8 / 2)$ & - & Rhyolite & Clayey diatom ooze \\
\hline \multirow{3}{*}{$\begin{array}{l}35 \\
36\end{array}$} & & 2.13 & 116.7 & 二 & $1 \times 6$ & Light gray $(2.5 \mathrm{Y} 7 / 1)$ & $=$ & - & Clayey diatom ooze \\
\hline & h & 2.22 & 125.5 & - & $2 \times 4$ & Light gray $(2.5 \mathrm{Y} 7 / 1)$ & - & Rhyolite & Clayey diatom ooze \\
\hline & & 2.23 & 126.0 & 2 & & & - & - & Clayey diatom ooze \\
\hline 37 & & 2.25 & 128.7 & 5 & $2 \times 3$ & Yellowish gray $(2.5 Y 4 / 1)$ & $(1.8 \mathrm{Y} 1.6 / 5)$ & - & Clayey diatom ooze \\
\hline & & 2.29 & 130.3 & - & & & - & - & Clayey diatom ooze \\
\hline & & 2.31 & 131.2 & - & & & - & - & Clayey diatom ooze \\
\hline & & 2.32 & 132.5 & - & & & - & - & Clayey diatom ooze \\
\hline & & 2.33 & 132.8 & - & & & - & - & Clayey diatom ooze \\
\hline & & 2.35 & 133.3 & - & & & $=$ & $=$ & Clayey diatom ooze \\
\hline & & 2.37 & 133.6 & - & & & - & 二 & Clayey diatom ooze \\
\hline & & 2.40 & 133.9 & $=$ & & & $=$ & 二 & Clayey diatom ooze \\
\hline & & 2.41 & 137.2 & $=$ & & & $=$ & $=$ & Clayey diatom ooze \\
\hline & & 2.42 & 137.8 & - & & & - & $=$ & Clayey diatom ooze \\
\hline & & 2.43 & 138.1 & $=$ & & & - & - & Clayey diatom ooze \\
\hline & & 2.43 & 138.3 & - & & & - & - & Clayey diatom ooze \\
\hline 41 & & 2.43 & 139.4 & - & $1 \times 8$ & Light gray $(2.5 Y 7 / 1)$ & Dark green -black & $\overline{-}$ & Clayey diatom ooze \\
\hline 41 & & 2.43 & 144.5 & $=$ & $1 \times 0$ & Ligmingay $(2.57$, in) & Dark green-black & - & Clayey diatom ooze \\
\hline 43 & b & 2.44 & 147.1 & 7 & & Light gray $(2.5 \times 8 / 1)$ & Dark green $\sim$ black & Rhyolite & Clayey diatom ooze \\
\hline 44 & & 2.44 & 147.8 & - & $1 \times 2$ & Light gray $(2.5 \mathrm{Y} 7 / 1)$ & Dark green black & Andesite-rhyolite & Clayey diatom ooze \\
\hline 45 & & 2.45 & 148.1 & - & $2 \times 3$ & Dark grayish yellow ( $2.5 \mathrm{Y}$ & Dark green-black & Andesite-dacite & Clayey diatom ooze \\
\hline & $c$ & & & & & $\begin{array}{l}4 / 2) \\
4\end{array}$ & & & \\
\hline 46 & $\mathrm{c}$ & $\begin{array}{l}2.46 \\
248\end{array}$ & $\begin{array}{l}148.2 \\
15.8\end{array}$ & $\begin{array}{l}18 \\
7\end{array}$ & $1 \times 3$ & Light gray $(2.5 Y 8 / 1)$ & $\begin{array}{l}\text { Black light gray } \\
\text { Black light gray }\end{array}$ & Andesite-dacite & $\begin{array}{l}\text { Clayey diatom ooze } \\
\text { Clayey diatom ooze }\end{array}$ \\
\hline & & $\begin{array}{l}2.48 \\
2.50\end{array}$ & 153.6 & 4 & & & $\begin{array}{l}\text { Black -light gray } \\
\text { Black light gray }\end{array}$ & $=$ & Clayey diatom ooze \\
\hline & & 2.52 & 155.7 & 6 & & & Black light gray & $=$ & Clayey diatom ooze \\
\hline & & 2.54 & 157.6 & 10 & & & Black-white & & Clayey diatom ooze \\
\hline $47,48,49$ & & 2.60 & 158.9 & - & $1 \times 5$ & Grayish yellow $(2.5 \mathrm{Y} 6 / 2)$ & Black-white & Andesite & Clayey diatom ooze \\
\hline & & 2,80 & 159.1 & 1 & & & Black-white & - & Clayey diatom ooze \\
\hline & & 2.81 & 159.4 & - & & & Black-white & - & Clayey diatom ooze \\
\hline & & 2.82 & 160.7 & 2 & & & Black-white & - & Clayey diatom ooze \\
\hline & & 3.00 & 164.1 & 14 & & & Black-white & - & Clayey diatom ooze \\
\hline
\end{tabular}

Note: $-=$ data not available . 
A

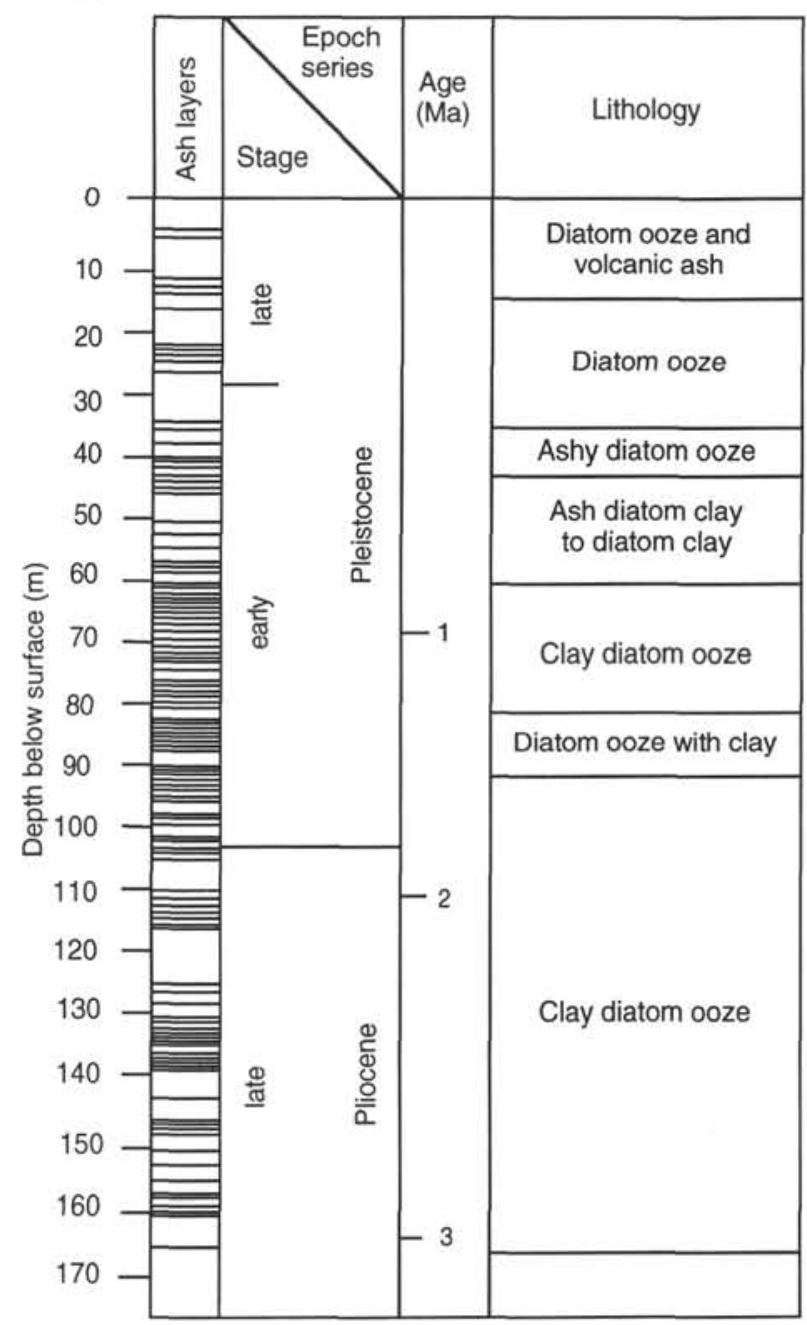

B

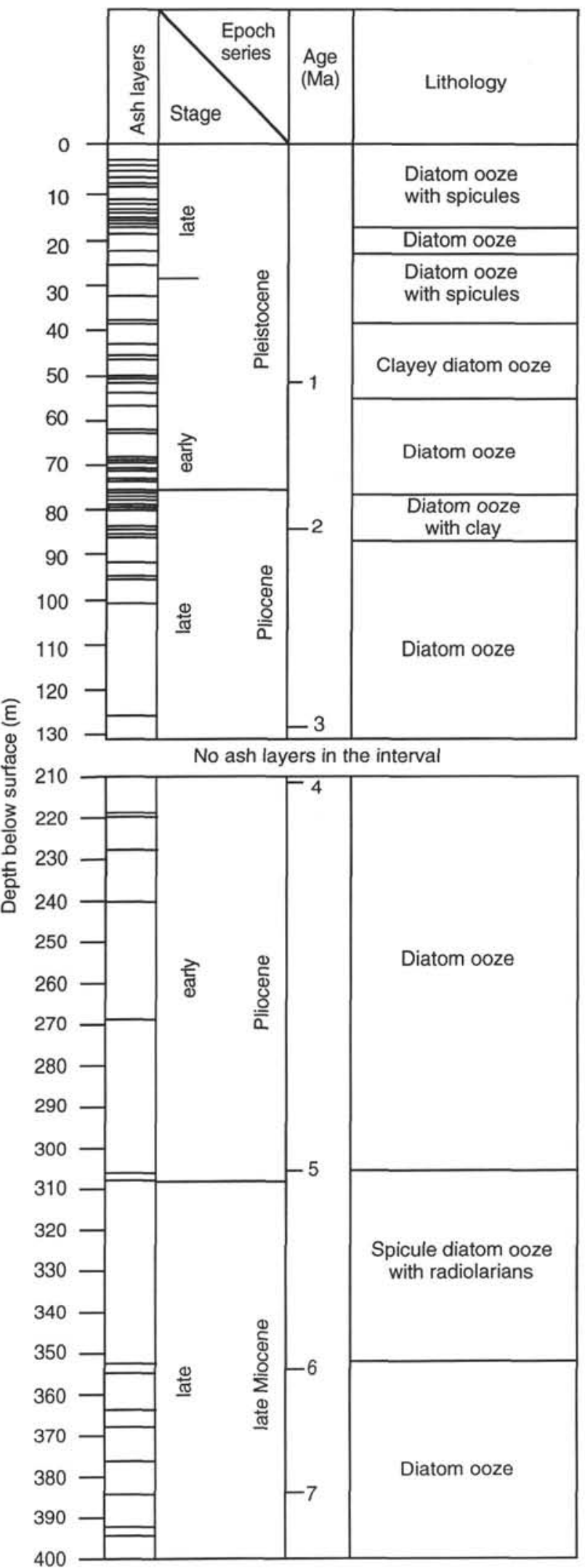

Figure 2. Representation of ash layer occurrence, age and lithology. A. Site 881 . B. Site 882 . C. Site 883 . D. Site 884. 
C

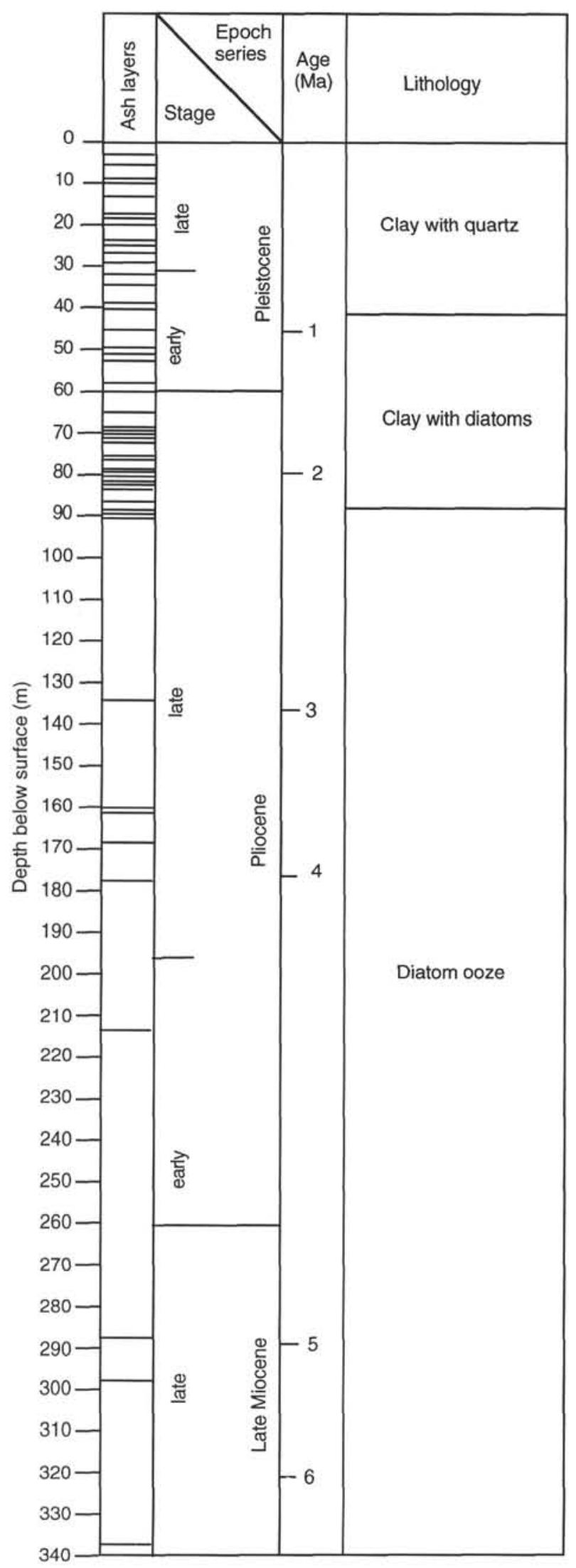

D

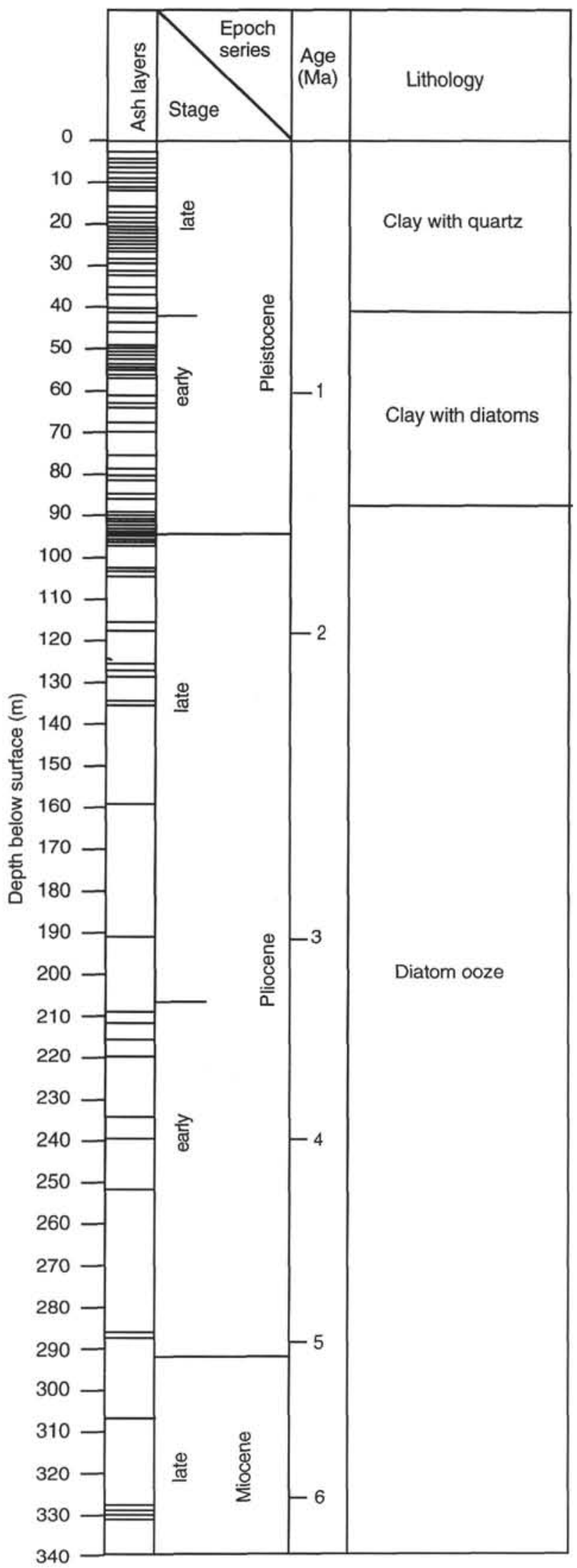

Figure 2 (continued). 
Table 2. Stratigraphic and lithological characteristics of volcanic ash layers from Hole 882A.

\begin{tabular}{|c|c|c|c|c|c|c|}
\hline $\begin{array}{l}\text { UNE } \\
\text { number }\end{array}$ & $\begin{array}{c}\text { Group } \\
\text { number }\end{array}$ & $\begin{array}{l}\text { Age } \\
\text { (Ma) }\end{array}$ & $\begin{array}{l}\text { Depth } \\
\text { (mbsf) }\end{array}$ & $\begin{array}{l}\text { Thickness } \\
(\mathrm{cm})\end{array}$ & $\begin{array}{c}\text { Size of vitric } \\
\text { shard }(0.01 \mathrm{~mm})\end{array}$ & $\begin{array}{c}\text { Color } \\
\text { (dry sample) }\end{array}$ \\
\hline \multirow[t]{3}{*}{52} & & 0.100 & 2.0 & 1 & $1 \times 5$ & Light gray (2.5Y 7/1) \\
\hline & & 0.150 & 2.9 & 1 & & \\
\hline & & 0.200 & 4.4 & 12 & & \\
\hline \multirow[t]{4}{*}{54} & 1 & 0.350 & 8.1 & 8 & $0.5 \times 5$ & Light gray (2.5Y 7/1) \\
\hline & & 0.370 & 9.6 & 5 & & \\
\hline & & 0.390 & 9.9 & 13 & & \\
\hline & & 0.420 & 12.3 & 6 & & \\
\hline \multirow[t]{3}{*}{55} & 1 & 0.450 & 13.4 & 5 & $1 \times 5$ & Light gray (2.5Y 8/1) \\
\hline & & 0.450 & 14.3 & 7 & & \\
\hline & & 0.450 & 14.6 & 1 & & \\
\hline 56 & e & 0.451 & 16.3 & - & $4 \times 8$ & Yellowish gray $(2.5 \mathrm{Y} 6 / 1)$ \\
\hline \multirow[t]{4}{*}{57} & 1 & 0.452 & 16.5 & - & $1 \times 3$ & Light gray $(2.5 \mathrm{Y} 7 / 1)$ \\
\hline & & 0.455 & 17.0 & 4 & & \\
\hline & & 0.460 & 17.4 & 3 & & \\
\hline & & 0.465 & 19.2 & 6 & & \\
\hline \multirow[t]{2}{*}{58} & i & 0.470 & 22.9 & 4 & $1 \times 8$ & Light gray (2.5Y $7 / 1)$ \\
\hline & & 0.472 & 25.0 & 3 & & \\
\hline \multirow[t]{3}{*}{60} & e & 0.480 & 32.4 & 6 & $1 \times 5$ & Grayish yellow $(2.5 Y 7 / 2)$ \\
\hline & & 0.580 & 37.3 & 5 & & \\
\hline & & 0.600 & 38.1 & 12 & & \\
\hline 61 & g & 0.670 & 43.2 & 3 & $0.5 \times 2$ & Light gray $(2.5 Y 7 / 1)$ \\
\hline \multirow[t]{4}{*}{62} & $\mathrm{e}$ & 0.850 & 46.9 & 18 & $1 \times 7$ & Light gray $(2.5 Y 7 / 1)$ \\
\hline & & 0.890 & 47.8 & 5 & & \\
\hline & & 1.000 & 49.7 & 9 & & \\
\hline & & 1.020 & 49.9 & 5 & & \\
\hline \multirow{5}{*}{63} & d & 1.050 & 51.4 & 6 & $1 \times 7$ & Light gray (2.5Y $7 / 1)$ \\
\hline & & 1.140 & 54.9 & 20 & & \\
\hline & & 1.230 & 57.0 & 1 & & \\
\hline & & 1.350 & 51.3 & 5 & & \\
\hline & & 1.370 & 61.8 & 8 & & \\
\hline \multirow[t]{2}{*}{64} & e & 1.500 & 68.0 & 2 & $1 \times 5$ & Light gray $(2.5 Y 8 / 2)$ \\
\hline & & 1.510 & 68.7 & 6 & & \\
\hline \multirow{4}{*}{66} & b & 1.550 & 68.9 & 9 & $2 \times 10$ & Light gray $(2.5 Y 8 / 2)$ \\
\hline & & 1.590 & 70.6 & 8 & $2 \times 5$ & Yellowish gray (2.5Y 5/1) \\
\hline & & 1.610 & 71.1 & 1 & & \\
\hline & & 1.650 & 73.7 & 3 & & \\
\hline 67 & b & 1.690 & 73.9 & 10 & $1.5 \times 4$ & Light gray (2.5Y 8/2) \\
\hline \multirow[t]{3}{*}{68} & g & 1.720 & 74.9 & 4 & $1 \times 5$ & Light gray $(2.5 \mathrm{Y} 7 / 1)$ \\
\hline & & 1.790 & 76.3 & 2 & & \\
\hline & & 1.800 & 76.5 & 1 & & \\
\hline 69 & e & 1.810 & 76.9 & 5 & $1 \times 3$ & Yellowish gray $(2.5 Y 6 / 1)$ \\
\hline & & 1.830 & 78.0 & 1 & & \\
\hline 70 & $\mathrm{f}$ & 1.850 & 79.1 & 11 & $3 \times 5$ & Yellowish gray $(2.5 Y$ 6/1) \\
\hline & & 1.860 & 79.5 & 1 & & \\
\hline 71 & d & 1.980 & 82.0 & 10 & $0.5 \times 5$ & Light gray $(2.5 \mathrm{Y} 7 / 1)$ \\
\hline 72 & & 1.980 & 82.8 & 2 & $3 \times 5$ & Light gray (2.5Y $8 / 1)$ \\
\hline 73 & e & 2.050 & 83.3 & 4 & $1 \times 4$ & Light gray $(2.5 Y 7 / 1)$ \\
\hline 74 & $f$ & 2.060 & 84.1 & 4 & $2 \times 2$ & Dark olive brown $(2.5 Y 3 / 3)$ \\
\hline & & 2.300 & 91.0 & 2 & & \\
\hline 75,76 & $\mathrm{j}$ & 2.550 & 94.8 & 16 & $1.5 \times 3$ & Grayish yellow $(2.5 Y$ $6 / 2)$ \\
\hline & & 2.600 & 95.3 & 4 & & \\
\hline 77 & g & 2.710 & 100.2 & 8 & $1 \times 3$ & Yellowish gray $(2.5 Y 6 / 1)$ \\
\hline & & 3.000 & 128.4 & 2 & & \\
\hline 78 & $\mathrm{j}$ & 4.030 & 216.2 & 14 & $3 \times 5$ & Yellowish gray $(2.5$ Y $5 / 1)$ \\
\hline 79 & $\hat{j}$ & 4.050 & 218.8 & 13 & $2 \times 3$ & Yellowish gray (2.5Y 5/1) \\
\hline 80 & & 4.100 & 223.8 & 6 & $4 \times 10$ & \\
\hline & & 4.300 & 237.6 & 3 & & \\
\hline & & 4.700 & 260.9 & 5 & & \\
\hline & & 5.000 & 297.8 & 1 & & \\
\hline & & 5.100 & 300.4 & 1 & & \\
\hline & & 5.200 & 302.8 & 3 & & \\
\hline & & 5.700 & 344.9 & 14 & & \\
\hline 81 & c & 6.100 & 347.9 & 5 & $1 \times 5$ & Light gray (2.5Y $8 / 1)$ \\
\hline 82 & b & 6.370 & 356.3 & 19 & $2 \times 10$ & Grayish yellow $(2.5 Y \quad 7 / 2)$ \\
\hline & & 6.800 & 360.0 & 6 & & \\
\hline 83 & b & 6.850 & 369.1 & 14 & $2.5 \times 15$ & Light gray $(2.5 \mathrm{Y} 7 / 1)$ \\
\hline 84 & a & 7.000 & 380.7 & 13 & $1 \times 4$ & Light gray $(2.5 \mathrm{Y} 8 / 1)$ \\
\hline 85 & a & 7.150 & 391.6 & 4 & $2 \times 5$ & Light gray $(2.5 \mathrm{Y} 7 / 1)$ \\
\hline 86 & a & 7.200 & 393.8 & 17 & $6 \times 20$ & Light gray $(2.5 \mathrm{Y} 7 / 1)$ \\
\hline
\end{tabular}

Kamchatka system, pulses of alkaline activity appear at different times in the evolution of the arc with a particularly prominent episode in the late Miocene. Of course, these episodes may be more related to geographic position, the nature of the subjacent arc crust and lithosphere, and tectonic events than a straightforward effect of crustal (or lithospheric) thickening at one locus of magma emission.

In the case of the IBM system, we know that the eruptive products of the Izu-Bonin arc changed subsequent to the development ( $\sim 25$ to $15 \mathrm{Ma}$ ) of the backarc Shikoku Basin, leading to decreasing alkalinity from 15 Ma to the present (Gill et al., 1994). It is postulated that melt extraction from a mantle source supplying the backarc basin leaves a refractory mantle that is then advected by coupled drag with the sub- ducted lithosphere toward the trench. Ingress of slab-derived fluids triggers renewed melting, leading to arc magmatism with the distinctive characteristics of derivation from refractory mantle sources, such as strongly light REE-depleted patterns. In contrast, despite a greater extent of backarc spreading (Parece Vela and Mariana Trough), no such effect is observed in the Marianas (Arculus et al., 1995).

It is possible that the documented along-strike variation in geochemical characteristics of the Kurile arc (Leonova, 1979) may be related to the differential south to north opening in the Miocene of the South Kurile backarc basin, but no such effects are possible in Kamchatka. We believe that knowledge of time-chemical relations of eruptive products in Kamchatka is not yet sufficient to recognize 
Table 2 (continued).

\begin{tabular}{|c|c|c|c|c|c|c|c|}
\hline $\begin{array}{l}\text { UNE } \\
\text { number }\end{array}$ & $\begin{array}{l}\text { Group } \\
\text { number }\end{array}$ & $\begin{array}{l}\text { Age } \\
\text { (Ma) }\end{array}$ & $\begin{array}{l}\text { Depth } \\
\text { (mbsf) }\end{array}$ & $\begin{array}{l}\text { Thickness } \\
(\mathrm{cm})\end{array}$ & $\begin{array}{c}\text { Color } \\
\text { (shipboard estimate) }\end{array}$ & Composition & Lithology \\
\hline \multirow[t]{3}{*}{52} & & 0.100 & 2.0 & 1 & Dark & - & Diatom ooze with spicules \\
\hline & & 0.150 & 2.9 & i & Dark & - & Diatom ooze with spicules \\
\hline & & 0.200 & 4.4 & 12 & $(9 \mathrm{Y} 0.3 / 0.2)$ & - & Diatom ooze with spicules \\
\hline \multirow[t]{4}{*}{54} & I & 0.350 & 8.1 & 8 & Light brown $\sim$ dark green & Andesite-dacite & Diatom ooze with spicules \\
\hline & & 0.370 & 9.6 & 5 & Dark & - & Diatom ooze with spicules \\
\hline & & 0.390 & 9.9 & 13 & Light & - & Diatom ooze with spicules \\
\hline & & 0.420 & 12.3 & 6 & Dark & - & Diatom ooze with spicules \\
\hline \multirow[t]{3}{*}{55} & 1 & 0.450 & 13.4 & 5 & Dark & Rhyolite & Diatom ooze with spicules \\
\hline & & 0.450 & 14.3 & 7 & Light & - & Diatom ooze with spicules \\
\hline & & 0.450 & 14.6 & i & Light & - & Diatom ooze with spicules \\
\hline 56 & e & 0.451 & 16.3 & - & Light & Dacite-rhyolite & Diatom ooze with spicules \\
\hline \multirow[t]{4}{*}{57} & $i$ & 0.452 & 16.5 & - & Light & Andesite-dacite & Diatom ooze with spicules \\
\hline & & 0.455 & 17.0 & 4 & Light & - & Diatom ooze with spicules \\
\hline & & 0.460 & 17.4 & 3 & Dark green & - & Diatom ooze with spicules \\
\hline & & 0.465 & 19.2 & 6 & Dark green & - & Diatom ooze \\
\hline \multirow[t]{2}{*}{58} & i & 0.470 & 22.9 & 4 & Dark green & Rhyolite & Diatom ooze \\
\hline & & 0.472 & 25.0 & 3 & Dark green & - & Diatom ooze \\
\hline \multirow[t]{3}{*}{60} & e & 0.480 & 32.4 & 6 & Dark green & Rhyolite & Calcareous diatom ooze with spicules \\
\hline & & 0.580 & 37.3 & 5 & Dark green & - & Calcareous diatom ooze with spicules \\
\hline & & 0.600 & 38.1 & 12 & Dark green & - & Diatom ooze with calcite \\
\hline 61 & $\mathrm{~g}$ & 0.670 & 43.2 & 3 & Dark green & Andesite-dacite & Diatom ooze with calcite \\
\hline \multirow[t]{4}{*}{62} & $\mathrm{e}$ & 0.850 & 46.9 & 18 & Dark green & Andesite-dacite & Clayey diatom ooze \\
\hline & & 0.890 & 47.8 & 5 & Dark green & - & Clayey diatom ooze \\
\hline & & 1.000 & 49.7 & 9 & Dark green & - & Clayey diatom ooze \\
\hline & & 1.020 & 49.9 & 5 & Dark green & - & Clayey diatom ooze \\
\hline \multirow[t]{5}{*}{63} & d & 1.050 & 51.4 & 6 & Dark green & Rhyolite & Clayey diatom ooze \\
\hline & & 1.140 & 54.9 & 20 & Light gray $(2.9 \mathrm{Y} 4.0 / 1.1)$ & - & Clayey diatom ooze \\
\hline & & 1.230 & 57.0 & 1 & Dark green & - & Diatom ooze with clay \\
\hline & & 1.350 & 51.3 & 5 & Dark green & - & Diatom ooze with clay \\
\hline & & 1.370 & 61.8 & 8 & Dark green & - & Diatom ooze with clay \\
\hline \multirow[t]{2}{*}{64} & e & 1.500 & 68.0 & 2 & Light brown(8.3YR $3.7 / 1.5)$ & Rhyolite & Diatom ooze \\
\hline & & 1.510 & 68.7 & 6 & $\sim$ Dark brown(5.IYR 1.8/0.6) & - & Diatom ooze \\
\hline 65 & b & 1.550 & 68.9 & 9 & Light brown (8.3YR 3.7/1.5) & Rhyolite & Diatom ooze \\
\hline \multirow[t]{3}{*}{66} & & 1.590 & 70.6 & 8 & - Dark brown(5.1YR 1.8/0.6) & - & Diatom ooze \\
\hline & & 1.610 & 71.1 & 1 & Light brown $(8.3$ YR $3.7 / 1.5)$ & - & Diatom ooze \\
\hline & & 1.650 & 73.7 & 3 & $\sim$ Dark brown(5.1YR 1.8/0.6) & - & Diatom ooze \\
\hline 67 & b & 1.690 & 73.9 & 10 & Light brown $(8.3$ YR $3.7 / 1.5)$ & Rhyolite & Diatom ooze \\
\hline 68 & $\mathrm{~g}$ & 1.720 & 74.9 & 4 & -Dark brown(5.IYR 1.8/0.6) & Rhyolite & Diatom ooze \\
\hline & & 1.790 & 76.3 & 2 & Gray $(2.5 Y 1.6 / 1.1)$ & - & Diatom ooze with clay \\
\hline & & 1.800 & 76.5 & $i$ & Gray( $2.5 Y 1.6 / 1.1)$ & - & Diatom ooze with clay \\
\hline 69 & e & 1.810 & 76.9 & 5 & Gray $(2.5 Y 1.6 / 1.1)$ & Dacite-rhyolite & Diatom ooze with clay \\
\hline & & 1.830 & 78.0 & 1 & Brown $(9.4$ YR 2.4/1.1) & - & Diatom ooze with clay \\
\hline 70 & f & 1.850 & 79.1 & 11 & Gray $(2.5 Y$ 1.6/1.1) & Andesite-dacite & Diatom ooze with clay \\
\hline & & 1.860 & 79.5 & 1 & Gray(2.5Y $1.6 / 1.1)$ & - & Diatom ooze with clay \\
\hline 71 & d & 1.980 & 82.0 & 10 & Gray $(2.5 Y 1.6 / 1.1)$ & Rhyolite & Diatom ooze with clay \\
\hline 72 & & 1.980 & 82.8 & 2 & Brown $(9.4$ YR $2.4 / 1.1)$ & - & Diatom ooze with clay \\
\hline 73 & e & 2.050 & 83.3 & 4 & Gray $(2.5 Y 1.6 / 1.1)$ & Rhyolite & Diatom ooze with clay \\
\hline 74 & $f$ & 2.060 & 84.1 & 4 & Gray $(2.5 Y 1.6 / 1.1)$ & Andesite & Diatom ooze with clay \\
\hline & & 2.300 & 91.0 & 2 & $(0.9$ YR $2.6 / 0.9)$ & - & Diatom ooze with clay and ash \\
\hline 75,76 & $\mathrm{j}$ & 2.550 & 94.8 & 16 & $(0.9$ YR $2.6 / 0.9)$ & - & Diatom ooze \\
\hline & J & 2.600 & 95.3 & 4 & $(0.9$ YR $2.6 / 0.9)$ & & Diatom ooze \\
\hline 77 & $\mathrm{~g}$ & 2.710 & 100.2 & 8 & (0.9YR 2.6/0.9) & Dacite-rhyolite & Diatom ooze \\
\hline & & 3.000 & 128.4 & 2 & Light gray & & Diatom ooze with spicules \\
\hline 78 & j & 4.030 & 216.2 & 14 & - & Basalt-andesite & Diatom ooze \\
\hline 79 & $\hat{j}$ & 4.050 & 218.8 & 13 & Dark & Basalt-andesite & Diatom ooze \\
\hline 80 & & 4.100 & 223.8 & 6 & Dark & - & Diatom ooze \\
\hline & & 4.300 & 237.6 & 3 & - & - & Diatom ooze \\
\hline & & 4.700 & 260.9 & 5 & $(5.8 Y 4.4 / 0.7)$ & - & Diatom ooze \\
\hline & & 5.000 & 297.8 & 1 & Dark green & - & Spicule diatom ooze with radiolarians \\
\hline & & 5.100 & 300.4 & i & Dark green & - & Spicule diatom ooze with radiolarians \\
\hline & & 5.200 & 302.8 & 3 & Dark green & - & Spicule diatom ooze with radiolarians \\
\hline & & 5.700 & 344.9 & 14 & Light gray $(3.1 Y$ Y 5.0/0.9) & - & Diatom ooze \\
\hline 81 & c & 6.100 & 347.9 & 5 & Brown(7.7YR 2.8/0.8) & Rhyolite & Diatom ooze \\
\hline 82 & b & 6.370 & 356.3 & 19 & Dark green $(8.5$ YR $3.2 / 0.8)$ & Rhyolite & Diatom ooze \\
\hline & & 6.800 & 360.0 & 6 & Dark green(8.5YR $3.2 / 0.8$ ) & - & Diatom ooze \\
\hline 83 & b & 6.850 & 369.1 & 14 & Gray(2.6YR 3.4/0.7) & Rhyolite & Diatom ooze \\
\hline 84 & a & 7.000 & 380.7 & 13 & Dark gray $(2.2 \mathrm{Y} 3.8 / 0.6)$ & Rhyolite & Diatom ooze \\
\hline 85 & a & 7.150 & 391.6 & 4 & Dark & Rhyolite & Diatom ooze \\
\hline 86 & a & 7.200 & 393.8 & 17 & Light & Rhyolite & Diatom ooze \\
\hline
\end{tabular}

Note: $-=$ data not available.

patterns or cyclicity in composition. It is interesting to note, however, two general features of occurrence and distribution of arc magmatism that merit further study. The first is the remarkable increase in the across-strike distribution of volcanism in sectors of the Izu-BoninHonshu-Hokkaido-Kurile-Kamchatka arc, which is underlain in part by continental lithosphere. In the case of northeastern Honshu, there are currently two active chains of volcanoes (Nasu and Chokai zones) and in Kamchatka, there are three (EK, CKD, and SR). The across-strike spread of magmatism $(\sim 400 \mathrm{~km})$ contrasts strongly with the apparently restricted geographic spread of magma emission in the Izu-Bonin and Kurile sectors of the arc. Direct chemical involvement of ancient continental lithosphere may be traced in the future with $\mathrm{Pb}$ isotopic studies in combination with $\mathrm{Th} / \mathrm{U}$ disequilibria studies. But in addition, the physical factors controlling migration and channeling of melts in the mantle beneath subarc continental vs. oceanic lithosphere deserve further attention (Spiegelman and McKenzie, 1987).

The second feature of note is the apparent absence of an explosive record at Site 881 during the period of South Kurile backarc basin opening in the early to middle Miocene (Kimura and Tamaki, 1985). The question of synchroneity of arc vs. backarc magmatism has been controversial since the results of DSDP efforts in the Philippine plate became known. It has been argued by some (Scott and Kroenke, 1980) that arc activity ceases during backarc spreading, whereas others (Karig, 1974, 1983; Hussong and Uyeda, 1982) assert a continuity of 
Table 3. Stratigraphic and lithological characteristics of volcanic ash layers from Hole 883B.

\begin{tabular}{|c|c|c|c|c|c|c|c|c|c|}
\hline $\begin{array}{l}\text { Leg } 145 \\
\text { number }\end{array}$ & $\begin{array}{l}\text { UNE } \\
\text { number }\end{array}$ & $\begin{array}{l}\text { Age } \\
\text { (Ma) }\end{array}$ & $\begin{array}{l}\text { Depth } \\
\text { mbsf) }\end{array}$ & $\begin{array}{l}\text { Thickness } \\
(\mathrm{cm})\end{array}$ & $\begin{array}{c}\text { Size of vitric } \\
\text { shard }(0.01 \mathrm{~mm})\end{array}$ & $\begin{array}{c}\text { Color } \\
\text { (dry sample) }\end{array}$ & $\begin{array}{c}\text { Color } \\
\text { (shipboard estimate) }\end{array}$ & Composition & Lithology \\
\hline 1 & 87 & 0.10 & 2.6 & 7 & $2 \times 5$ & Light yellow $(2.5 Y 7 / 3)$ & $\operatorname{Tan}(6.6 \mathrm{Y} 3.3 / 0.6)$ & Rhyolite & Clay with quartz \\
\hline 2 & & 0.25 & 6.3 & 6 & & & Black(3.9YR 2.7/0.5) & - & Clay with quartz. \\
\hline 3 & 89 & 0.30 & 8.5 & 6 & $1 \times 8$ & Light gray (2.5Y $7 / 1)$ & Black (3.9YR 2.7/0.5) & Rhyolite & Clay with quartz \\
\hline 4 & & 0.30 & 8.8 & 3 & & & Black (3.9YR 2.7/0.5) & - & Clay with quartz \\
\hline 5 & & 0.31 & 11.5 & 3 & & & Black (3.9YR 2.7/0.5) & - & Clay with quartz \\
\hline 6 & & 0.33 & 15.5 & 1 & & & Black (3.9YR 2.7/0.5) & - & Clay with quartz \\
\hline 7 & 90 & 0.36 & 16.4 & 15 & $5 \times 10$ & Yellowish gray $(2.5 Y 5 / 1)$ & Black (3.9YR 2.7/0.5) & Andesite-dacite & Clay with quartz \\
\hline 8 & & 0.37 & 17.5 & 5 & & & Black(3.9YR 2.7/0.5) & - & Clay with quartz \\
\hline 9 & & 0.42 & 21.4 & 5 & & & Gray $(2.5 Y 4.0 / 0.5)$ & - & Clay with quartz \\
\hline 10 & 91 & 0.45 & 22.9 & 4 & $3 \times 5$ & Yellowish gray $(2.5 \mathrm{Y} 4 / 1)$ & Black(1.2RP 2.1/0.7) & Andesite-dacite & Clay with quartz \\
\hline 11 & & 0.46 & 24.0 & 4 & & & Gray $(2.5 Y 4.0 / 0.5)$ & - & Clay with quartz \\
\hline 12 & 92 & 0.47 & 26.0 & 8 & $3 \times 5$ & Light gray $(2.5 \mathrm{Y} 8 / 1)$ & Gray $(2.5 Y 4.0 / 0.5)$ & Rhyolite & Clay with quartz \\
\hline 13 & 93 & 0.60 & 29.3 & 4 & $2 \times 4$ & Yellowish gray $(2.5 \mathrm{Y} 6 / 1)$ & Gray green $(0.53 .3 / 0.5)$ & Andesite-dacite & Clay with diatoms \\
\hline 14 & & 0.70 & 31.6 & 4 & & & Gray green $(0.53 .3 / 0.5)$ & - & Clay with diatoms \\
\hline 15 & & 0.80 & 36.9 & 16 & & & Green(3.0Y 2.8/0.9) & - & Clay with quartz \\
\hline 16 & & 0.90 & 38.9 & 8 & & & Green $(3.0 Y 2.8 / 0.9)$ & - & Clay with quartz \\
\hline 17 & 94 & 1.06 & 41.5 & 4 & $1 \times 3$ & Yellowish gray $(2.5 \mathrm{Y} 6 / 1)$ & Green $(3.0 Y 2.8 / 0.9)$ & Dacite-rhyolite & Clay with diatoms \\
\hline 18 & 95 & 1.13 & 46.4 & 2 & $2 \times 7$ & Light gray $(2.5 \mathrm{Y} 7 / 1)$ & Dark gray $(0.9 Y 3.0 / 0.7)$ & Rhyolite & Clay with diatoms \\
\hline 19 & 96 & 1.15 & 48.0 & 10 & $0.5 \times 10$ & Yellowish gray $(2.5 \mathrm{Y} 6 / 1)$ & Dark gray $(0.9$ Y $3.0 / 0.7)$ & Rhyolite & Clay with diatoms \\
\hline 20 & 97 & 1.20 & 49.7 & 7 & $1 \times 15$ & Yellowish gray $(2.5 Y 6 / 1)$ & Dark gray $(0.9$ Y $3.0 / 0.7)$ & Rhyolite & Clay with diatoms \\
\hline 21 & & 1.30 & 54.3 & 2 & & & Dark gray $(0.9$ Y $3.0 / 0.7)$ & - & Clay with diatoms \\
\hline 22 & & 1.40 & 56.4 & 10 & & & & - & Clay with diatoms \\
\hline 23 & & 1.50 & 60.2 & 2 & & & & - & Clay with diatoms \\
\hline 24 & 98 & 1.70 & 63.2 & 18 & $1 \times 2$ & Light gray $(2.5 \mathrm{Y} 7 / 1)$ & & Rhyolite & Clay with diatoms \\
\hline 25 & & 1.71 & & 9 & & & & - & Clay with diatoms \\
\hline 26 & 99 & 1.71 & 63.6 & 9 & $2 \times 15$ & Light gray $(2.5 \mathrm{Y} 8 / 2)$ & & - & Clay with diatoms \\
\hline 27 & & 1.72 & 64.2 & 8 & & & & - & Clay with diatoms \\
\hline 28 & & 1.74 & 65.9 & 1 & & & & - & Clay with diatoms \\
\hline 29 & & 1.76 & 66.7 & i & & & & - & Clay with diatoms \\
\hline 30 & 100 & 1.79 & 69.6 & 10 & $1 \times 3$ & Yellowish gray $(2.5 Y 6 / 1)$ & & Rhyolite & Clay with diatoms \\
\hline 31 & 101 & 1.80 & 70.9 & 8 & $1 \times 3$ & Yellowish gray $(2.5$ Y $5 / 1)$ & & - & Clay with diatoms \\
\hline 32 & 102 & 1.96 & 72.9 & 1 & $1 \times 5$ & Light gray (2.5Y $7 / 1)$ & & Rhyolite & Clay with diatoms \\
\hline 33 & & 2.01 & 73.2 & 2 & & & & - & Clay with diatoms \\
\hline 34 & & 2.02 & 73.6 & 1 & & & & - & Clay with diatoms \\
\hline 35 & & 2.16 & 76.8 & 1 & & & & - & Clay with diatoms \\
\hline 36 & & 2.21 & 77.0 & $i$ & & & & - & Clay with diatoms \\
\hline 37 & & 2.26 & 79.9 & 5 & & & & - & Clay with diatoms \\
\hline 38 & & 2.30 & 80.9 & 1 & & & & - & Clay with diatoms \\
\hline 39 & 103 & 2.46 & 82.2 & 7 & $1 \times 6$ & Grayish yellow $(2.5 \mathrm{Y} 6 / 2)$ & & Rhyolite & Clay with diatoms \\
\hline 40 & 104 & 2.55 & 84.2 & 4 & $1 \times 5$ & Yellowish gray $(2.5 \mathrm{Y} 6 / 1)$ & & Dacite-rhyolite & Diatom ooze \\
\hline 41 & & 2.56 & 84.9 & $i$ & & & & - & Diatom ooze \\
\hline 42 & 106 & 2.87 & 122.6 & 8 & $1 \times 10$ & Light gray $(2.5 \mathrm{Y} 7 / 1)$ & & Rhyolite & Diatom ooze \\
\hline 43 & 107 & 3.79 & 188.7 & 9 & $2 \times 2$ & Yellowish gray $(2.5$ Y 5/1) & Black(1.8R 2.2/0.5) & Basaltic andesite & Diatom ooze \\
\hline 44 & & 3.80 & 190.0 & $\hat{1}$ & & & Black & - & Diatom ooze \\
\hline 45 & 108 & 3.82 & 195.8 & 7 & $3 \times 10$ & Light gray $(2.5 \mathrm{Y} 8 / 1)$ & Light gray & Rhyolite & Diatom ooze \\
\hline 46 & & 3.90 & 203.0 & $i$ & & & Light gray & - & Diatom ooze \\
\hline 47 & 109 & 4.41 & 239.7 & 5 & $2 \times 3$ & Light gray $(2.5 Y 7 / 1)$ & Dark brown $(6.0$ Y $3.3 / 1.2)$ & Andesite & Diatom calcareous ooze \\
\hline 48 & 110 & 5.63 & 312.8 & 21 & $1 \times 5$ & Light gray $(2.5 Y 7 / 1)$ & & Rhyolite & Diatom ooze \\
\hline 49 & 111 & 5.88 & 324.6 & 6 & $1 \times 5$ & Light gray $(2.5 \mathrm{Y} 7 / 1)$ & & Rhyolite & Diatom ooze \\
\hline 50 & 112 & 6.30 & 376.2 & 4 & $0.5 \times 5$ & Light gray $(2.5 \mathrm{Y} 7 / 1)$ & & Rhyolite & Diatom ooze \\
\hline 51 & 113 & 34.10 & 685.3 & 12 & $3 \times 4$ & Light gray $(2.5 \mathrm{Y} 7 / 1)$ & & Rhyolite & Nannofossil chalk \\
\hline 52 & & 34.25 & 713.5 & 2 & & & Black $(2.8 Y$ 2.8/1.1) & - & Nannofossil chalk \\
\hline 53 & 115 & 34.30 & 716.1 & 7 & $2 \times 4$ & Yellowish gray $(2.5 \mathrm{Y} 4 / 1)$ & $\operatorname{Black}(2.8 \mathrm{Y} 2.8 / 1.1)$ & Andesite & Nannofossil chalk \\
\hline 54 & 114 & 34.40 & 718.1 & 7 & $2 \times 4$ & Yellowish gray $(2.5 \mathrm{Y} 4 / 1)$ & Black $(2.8$ Y $2.8 / 1.1)$ & Andesite & Nannofossil chalk \\
\hline 55 & 116 & 37.70 & 722.1 & 5 & $1 \times 2$ & Yellowish gray $(2.5$ Y $5 / 1)$ & Dark brown & Basaltic andesite & Nannofossil chalk \\
\hline 56 & & 37.90 & 722.4 & 4 & & & Dark brown & - & Nannofossil chalk \\
\hline 57 & & 38.00 & 722.7 & 1 & & & Dark brown & - & Nannofossil chalk \\
\hline 58 & & 38.20 & 723.6 & i & & & Dark brown & - & Nannofossil chalk \\
\hline 59 & & 38.30 & 723.9 & i & & & Dark brown & - & Nannofossil chalk \\
\hline 60 & & 38.40 & 724.5 & 4 & & & Dark brown & - & Nannofossil chalk \\
\hline 61 & & 38.50 & 724.6 & 2 & & & Dark brown & - & Nannofossil chalk \\
\hline 62 & & 38.60 & 725.8 & 2 & & & Dark brown & - & Nannofossil chalk \\
\hline 63 & 117 & 38.70 & 726.7 & 5 & $2 \times 3$ & Yellowish gray $(2.5 \mathrm{Y} / 1 / 1)$ & Dark brown & Basaltic andesite & Nannofossil chalk \\
\hline 64 & & 38.90 & 726.8 & 3 & & & Dark brown & - & Nannofossil chalk \\
\hline 65 & & 40.00 & 732.0 & 2 & & & Dark brown & - & Nannofossil chalk \\
\hline 66 & & 40.10 & 733.0 & 9 & & & Dark brown & - & Nannofossil chalk \\
\hline 67 & & 40.80 & 733.7 & 6 & & & Dark brown & - & Nannofossil chalk \\
\hline 68 & 118 & 45.00 & 747.4 & 7 & $3 \times 5$ & Yellowish gray $(2.5 \mathrm{Y} 4 / 1)$ & Black & Basaltic andesite & Nannofossil chalk \\
\hline 69 & & 45.20 & 748.4 & 8 & & & Black & - & Nannofossil chalk \\
\hline 70 & & 46.00 & 752.4 & 4 & & & & - & Nannofossil chalk \\
\hline 71 & & 46.20 & 753.9 & 1 & & & & - & Nannofossil chalk \\
\hline 72 & 119 & 49.90 & 783.0 & 3 & & Yellowish gray (2.5Y 5/4) & Dark brown & - & Nannofossil chalk \\
\hline 73 & & 50.00 & 783.3 & 3 & & & Dark brown & - & Nannofossil chalk \\
\hline 74 & & $>50$ & 795.1 & 1 & & & Brown & - & Nannofossil chalk \\
\hline
\end{tabular}

Note: $-=$ data not available 

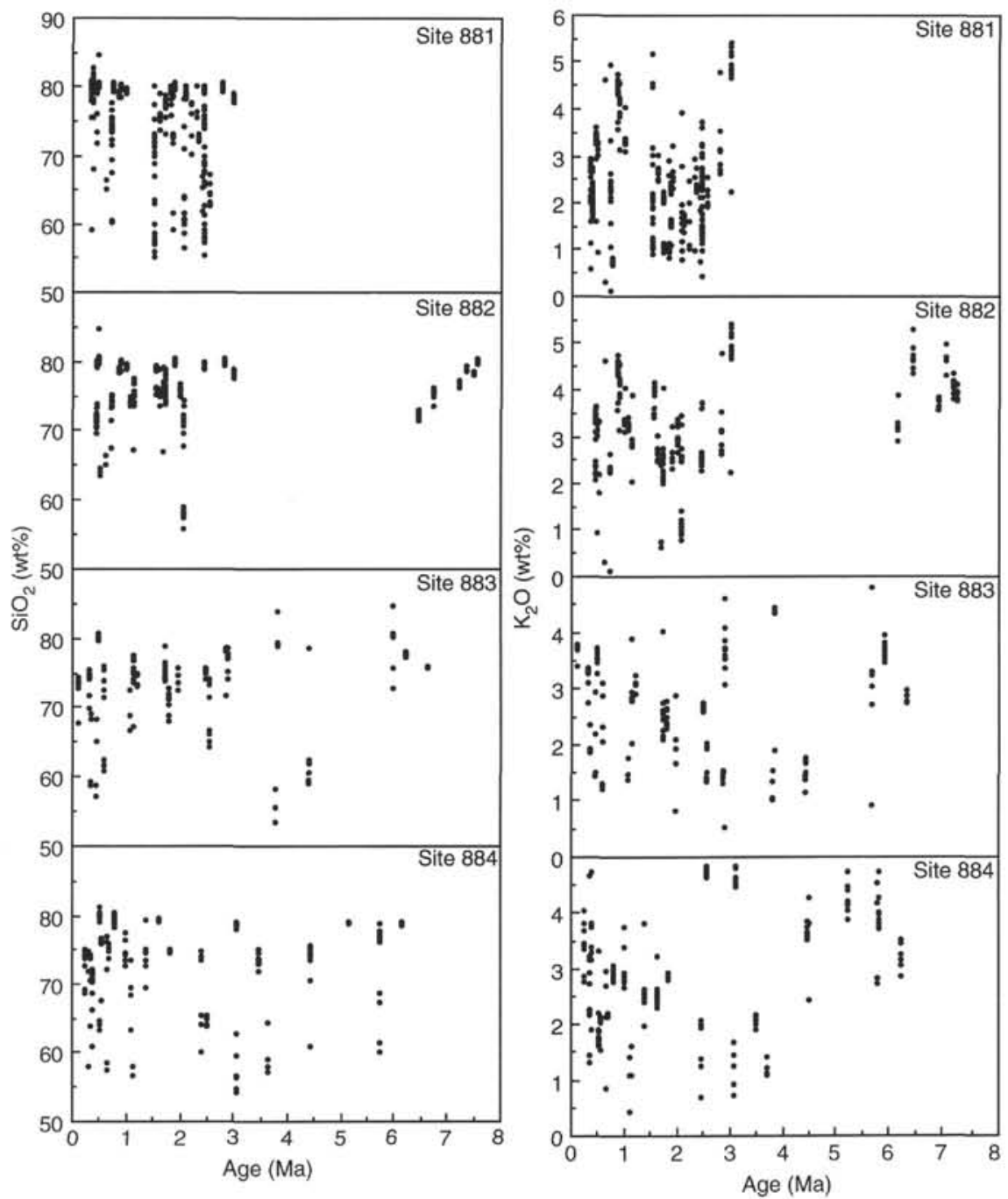

Figure 3. Variation of wt $\% \mathrm{SiO}_{2}$ and $\mathrm{K}_{2} \mathrm{O}$ as a function of age of the ash layers from Sites $881-884$, for the past 8 m.y.

activity in the arc. Cambray (1991) has suggested major increases in explosive activity accompany the initial stages of opening in the IzuBonin-Mariana system, but that this activity disappears during maximum spreading. In part, of course, the explosive record may not reflect the continuance of arc activity in the event of subsidence of the structure. In the case of the Izu-Bonin system, even the deposition of volcaniclastic-rich turbidites ceases at the initiation of true spreading in the Shikoku Basin (Taylor, 1992), but similar effects have not been documented in the Mariana system. Recovery of a temporal record of activity by drilling in the South Kurile Basin would resolve this issue for the Kurile situation.

Correlations of geochemical parameters of MORB with physical factors such as ridge crest depths and inferred percentages of melting in the mantle have proved to be successful on a global scale (Klein and Langmuir, 1987) even if problematic in detail. In a survey of the geochemistry of the world's arc systems, Plank and Langmuir (1988) discovered a remarkable degree of overlap between MORB and arc basalts, and suggested degrees of melting are controlled at least in part by arc crustal (or lithospheric) thicknesses. Given that island arcs are believed to be the locus of continental crustal growth, we might anticipate some indication of crustal thickening as a function of arc longevity (e.g., decreasing wt $\% \mathrm{CaO}$ and increasing $\mathrm{Na}_{2} \mathrm{O}$ at specific $\mathrm{MgO}$ ). At the least, a comparison of the ash data from Leg 145 with the available on-land data and with other arc systems is of interest.

In Figure 6, the covariation wt $\mathrm{CaO}$ with $\mathrm{MgO}$ is shown for the ashes in comparison with our data from EK and CKD and our data from the Izu-Bonin and Mariana systems. Some important features of note are:

1. A relatively restricted spread of ash compositions is apparent with no discernible trend toward lower $\mathrm{CaO}$ at fixed $\mathrm{MgO}$ with time;

2. Although samples with $6 \mathrm{wt} \% \mathrm{MgO}$ are sparse, a reasonable extrapolation of the data indicates $\sim 12 \mathrm{wt} \% \mathrm{CaO}$ at this level of $\mathrm{MgO}$ indicative of a crustal thickness of $\sim 14 \mathrm{~km}$;

3. The offset of the ash data to distinctly higher $\mathrm{CaO}$ contents than the currently active EK and CKD volcanoes possibly indicates recent crustal thickening. However, we note that the CKD is a major graben structure dominated overwhelmingly by basaltic activity, both of which seem unlikely consequences of crustal thickening;

4. We have found that the Izu-Bonin and Mariana ash data are essentially and remarkably coincident with the 881-884 ashes in terms of $\mathrm{CaO}$ vs. $\mathrm{MgO}$ characteristics, implying at face value an identity of crustal thicknesses between these diverse systems.

We suspect that part of the reason for the coincidence of the ash compositions from these different arc systems may be the phase chemical control of crystal-melt equilibria at equivalent, and probably relatively low, pressures within the arc crusts (Fig. 13). At a comparator of $6 \mathrm{wt} \% \mathrm{MgO}$ for example, it is possible that the melts are already sufficiently evolved for multiple phase (olivine-clinopyroxene-plagioclase-spinel) saturation. Contrasts in the nature of mantle source and melting regimes may have to be sought in the trace element systematics 
Table 4. Stratigraphic and lithological characteristics of volcanic ash layers from Hole 884B.

\begin{tabular}{|c|c|c|c|c|c|c|c|c|}
\hline $\begin{array}{l}\text { UNE } \\
\text { number }\end{array}$ & $\begin{array}{l}\text { Age } \\
\text { (Ma) }\end{array}$ & $\begin{array}{l}\text { Depth } \\
\text { (mbsf) }\end{array}$ & $\begin{array}{l}\text { Thickness } \\
(\mathrm{cm})\end{array}$ & $\begin{array}{l}\text { Size of vitric shard } \\
\quad(0.01 \mathrm{~mm})\end{array}$ & $\begin{array}{c}\text { Color } \\
\text { (dry sample) }\end{array}$ & $\begin{array}{c}\text { Color } \\
\text { (shipboard estimate) }\end{array}$ & Composition & Lithology \\
\hline & 0.10 & 0.3 & 1 & & & Green & - & Clay with diatoms \\
\hline & 0.70 & 2.6 & 2 & & & Green & - & Clay with diatoms \\
\hline & 0.10 & 3.5 & i & & & Green & - & Clay with diatoms \\
\hline & 0.12 & 4.1 & 10 & & & Green & - & Clay with diatoms \\
\hline & 0.18 & 5.1 & 6 & & & Green & - & Clay with diatoms \\
\hline & 0.22 & 7.3 & 7 & & & & $-\bar{x}$ & Diatom silty clay \\
\hline \multirow[t]{4}{*}{121} & 0.24 & 8.7 & 10 & $0.5 \times 5$ & Light gray $(2.5 Y 7 / 1)$ & & Dacite-rhyolite & Diatom silty clay \\
\hline & 0.25 & 9.7 & 17 & & & & & Diatom silty clay \\
\hline & 0.26 & 9.9 & 10 & & & & - & Diatom silty clay \\
\hline & 0.30 & 12.2 & 7 & & & & - & Diatom silty clay \\
\hline \multirow{9}{*}{$\begin{array}{l}122 \\
123\end{array}$} & 0.33 & 14.5 & 15 & $0.5 \times 5$ & Light gray $(2.5 \mathrm{Y} 7 / 1)$ & & Rhyolite & Diatom silty clay \\
\hline & 0.35 & 15.8 & 18 & $0.5 \times 3$ & Light gray $(2.5 \mathrm{Y} 7 / 1)$ & & Dacite-rhyolite & Diatom silty clay \\
\hline & 0.35 & 16.1 & 29 & & & & - & Clay with diatoms \\
\hline & 0.36 & 16.5 & 6 & & & & - & Clay with diatoms \\
\hline & 0.36 & 17.8 & 20 & & & & - & Clay with diatoms \\
\hline & 0.37 & 18.1 & 1 & & & & - & Clay with diatoms \\
\hline & 0.38 & 18.4 & 4 & & & & - & Clay with diatoms \\
\hline & 0.38 & 19 & 6 & & & & - & Clay with diatoms \\
\hline & 0.39 & 20 & 12 & & & & - & Clay with diatoms \\
\hline \multirow[t]{4}{*}{124} & 0.39 & 20.3 & 6 & $1 \times 3$ & Light gray $(2.5 \mathrm{Y} 7 / 1)$ & & Rhyolite & Clay with diatoms \\
\hline & 0.40 & 20.6 & i & & & & & Clay with diatoms \\
\hline & 0.45 & 24.3 & 5 & & & & Z & Clay with diatoms \\
\hline & 0.47 & 25.1 & 4 & & & & $\bar{z}$ & Clay with diatoms \\
\hline 125 & 0.51 & 28 & 11 & $1 \times 5$ & Light gray $(2.5 Y 7 / 1)$ & Light & Rhyolite & Diatom silty clay \\
\hline 126 & 0.52 & 28.4 & 12 & $2 \times 2$ & Dark grayish yellow (2.5Y 4/2) & Dark & Basaltic andesite & Diatom silty clay \\
\hline \multirow[t]{4}{*}{127} & 0.55 & 30.1 & 4 & $1 \times 10$ & Light gray $(2.5 Y 7 / 1)$ & Light & Rhyolite & Diatom silty clay \\
\hline & 0.56 & 31.8 & 12 & & & & - & Diatom silty clay \\
\hline & 0.62 & 36.5 & 1 & & & & - & Clay with diatoms \\
\hline & 0.63 & 36.7 & 7 & & & & - & Clay with diatoms \\
\hline 128 & 0.66 & 38.3 & 6 & $2 \times 3$ & Yellowish gray $(2.5 \mathrm{Y} 6 / 1)$ & & Andesite-dacite & Clay with diatoms \\
\hline \multirow[t]{9}{*}{129} & 0.69 & 40.6 & 11 & $0.5 \times 4$ & Grayish yellow $(2.5 \mathrm{Y} 7 / 2)$ & & Rhyolite & Clay with diatoms \\
\hline & 0.75 & 44.4 & 4 & & & & - & Clay with diatoms \\
\hline & 0.75 & 44.7 & 3 & & & & $\bar{z}$ & Clay with diatoms \\
\hline & 0.76 & 44.6 & 6 & & & & $=$ & Diatom ooze with clay, spicules and volcanic ash \\
\hline & 0.76 & 44.8 & $\begin{array}{l}0 \\
8\end{array}$ & & & & $\bar{z}$ & Diatom ooze with clay, spicules and volcanic ash \\
\hline & 0.78 & 46 & $118(36 \sim 40)$ & & & & $=$ & Diatom ooze with clay, spicules and volcanic ash \\
\hline & 0.78 & 46.3 & $118(36 \sim 40)$ & & & & - & Diatom ooze with clay, spicules and volcanic ash \\
\hline & 0.79 & 46.6 & $118(36 \sim 40)$ & & & & $\bar{z}$ & Diatom ooze with clay, spicules and volcanic ash \\
\hline & 0.79 & 46.9 & $118(36-40)$ & & & & $\bar{z}$ & Diatom ooze with clay, spicules and volcanic ash \\
\hline \multirow[t]{3}{*}{130} & 0.80 & 47.3 & $118(36 \sim 40)$ & $2 \times 20$ & Light gray $(2.5 Y 7 / 1)$ & & Rhyolite & Diatom ooze with clay, spicules and volcanic ash \\
\hline & 0.81 & 48.5 & 1 & & & & - & Diatom ooze with clay, spicules and volcanic ash \\
\hline & 0.82 & 49.3 & 24 & & & & - & Diatom ooze with clay, spicules and volcanic ash \\
\hline \multirow[t]{2}{*}{131} & 1.00 & 53.7 & 5 & $1 \times 3$ & Light gray $(2.5 \mathrm{Y} 7 / 1)$ & & Dacite-rhyolite & Diatom ooze with clay, spicules and volcanic ash \\
\hline & 1.01 & 56.2 & $41(44 \sim 45)$ & & & & & Diatom ooze with clay, spicules and volcanic ash \\
\hline 132 & 1.02 & 56.7 & $41(44-45)$ & $1 \times 5$ & Light gray (2.5Y $7 / 1)$ & & Rhyolite & Diatom ooze with clay, spicules and volcanic ash \\
\hline \multirow{3}{*}{$\begin{array}{l}132 \\
133\end{array}$} & 1.05 & 60.7 & 15 & $1 \times 3$ & Grayish yellow $(2.5 \mathrm{Y} 6 / 2)$ & & Knyome & $\begin{array}{l}\text { Diatom ooze with clay, spicules and volcanic ash } \\
\text {. }\end{array}$ \\
\hline & 1.07 & 62.6 & 5 & & Grayisn yenow (2.5) 012$)$ & & $=$ & Diatom ooze with clay, spicules and volcanic ash \\
\hline & 1.10 & $\begin{array}{l}0.0 \\
68.1\end{array}$ & 2 & & & & $\bar{z}$ & 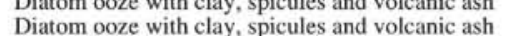 \\
\hline \multirow[t]{11}{*}{134} & 1.16 & 70.4 & 13 & $3 \times 5$ & Dark grayish yellow (2.5Y $5 / 2$ ) & & Basaltic andesite & Diatom ooze with clay, spicules and volcanic ash \\
\hline & 1.20 & 72.9 & $48(50 \sim 51)$ & & & & - & Diatom ooze with clay, spicules and volcanic ash \\
\hline & 1.22 & 73.2 & $48(50 \sim 51)$ & & & & - & Diatom ooze with clay, spicules and volcanic ash \\
\hline & 1.28 & 76.6 & 3 & & White & & - & Diatom ooze with clay, spicules and volcanic ash \\
\hline & 1.30 & 77.4 & 5 & & White & & - & Diatom ooze with clay, spicules and volcanic ash \\
\hline & 1.32 & 80.3 & $370(54-64)$ & & Dark brown (4.2YR 3.4/0.9) & & - & Diatom ooze with clay, spicules and volcanic ash \\
\hline & 1.33 & 80.6 & $370(54 \sim 64)$ & & Dark brown $(4.2 \mathrm{YR} 3.4 / 0.9)$ & & - & Diatom ooze with clay, spicules and volcanic ash \\
\hline & 1.33 & 80.9 & $370(54 \sim 64)$ & & Dark brown $(4.2 Y \mathrm{R} 3.4 / 0.9)$ & & $=$ & Diatom ooze with clay, spicules and volcanic ash \\
\hline & 1.37 & 81.2 & $370(54-64)$ & & Dark brown $(4.2$ YR $3.4 / 0.9)$ & & $=$ & Diatom ooze with clay, spicules and volcanic ash \\
\hline & 1.38 & 81.5 & $370(54-64)$ & & Dark brown $(4.2 \mathrm{YR} 3.4 / 0.9)$ & & $=$ & Diatom ooze with clay, spicules and volcanic ash \\
\hline & 1.39 & 81.8 & $370(54 \sim 64)$ & & Dark brown $(4.2 Y R 3.4 / 0.9)$ & & $=$ & Diatom ooze with clay, spicules and volcanic ash \\
\hline \multirow{6}{*}{135} & 1.40 & 82 & $370(54 \sim 64)$ & $1 \times 10$ & Light gray $(2.5 \mathrm{Y} 7 / 1)$ & Dark brown $(4.2$ YR $3.4 / 0.9)$ & Rhyolite & Diatom ooze with clay, spicules and volcanic ash \\
\hline & 1.42 & 82.1 & $370(54-64)$ & & Dark brown (4.2YR 3.4/0.9) & & Knyonte & Diatom ooze with clay, spicules and volcanic ash \\
\hline & 1.45 & 82.6 & $370(54-64)$ & & Brown (9.4YR 3.3/1.3) & & $=$ & Diatom ooze with clay, spicules and volcanic ash \\
\hline & 1.50 & 83 & $370(54 \sim 64)$ & & Brown (9.4YR 3.3/1.3) & & $=$ & Diatom ooze with clay, spicules and volcanic ash \\
\hline & 1.55 & 83.4 & $370(54 \sim 64)$ & & Brown (9.4YR 3.3/1.3) & & $=$ & Diatom ooze with clay, spicules and volcanic ash \\
\hline & 1.56 & 86.5 & 22 & & & & - & Diatom ooze with clay \\
\hline 136 & 1.63 & 93.5 & 28 & $1 \times 4$ & Light gray $(2.5 \mathrm{Y} 8 / 1)$ & & Rhyolite & Diatom clay \\
\hline
\end{tabular}


Table 4 (continued).

\begin{tabular}{|c|c|c|c|c|c|c|c|c|}
\hline $\begin{array}{l}\text { UNE } \\
\text { number }\end{array}$ & $\begin{array}{l}\text { Age } \\
\text { (Ma) }\end{array}$ & $\begin{array}{l}\text { Depth } \\
\text { (mbsf) }\end{array}$ & $\begin{array}{c}\text { Thickness } \\
(\mathrm{cm})\end{array}$ & $\begin{array}{l}\text { Size of vitric shard } \\
\quad(0.01 \mathrm{~mm})\end{array}$ & $\begin{array}{c}\text { Color } \\
\text { (dry sample) }\end{array}$ & $\begin{array}{c}\text { Color } \\
\text { (shipboard estimate) }\end{array}$ & Composition & Lithology \\
\hline & 1.64 & 93.8 & 8 & & & & - & Diatom clay \\
\hline & 1.83 & 94.9 & 5 & & & & - & Diatom clay \\
\hline \multirow[t]{5}{*}{137} & 1.89 & 105.9 & 11 & $0.5 \times 7$ & Yellowish gray $(2.5 Y$ 6/1) & & Rhyolite & Diatom clay \\
\hline & 2.13 & 108.1 & 3 & & & & & Diatom clay \\
\hline & 2.22 & 116 & 4 & & & & - & Diatom clay \\
\hline & 2.35 & 118.8 & 2 & & & & - & Diatom clay \\
\hline & 2.45 & 119.4 & 2 & & & & & Diatom clay \\
\hline 138 & 2.55 & 123.7 & 5 & $1 \times 7$ & Grayish yellow (2.5Y $6 / 2$ ) & & Rhyolite & Diatom clay \\
\hline \multirow{3}{*}{139} & 2.75 & 124.9 & 3 & $2 \times 3$ & Yellowish gray (2.5Y $6 / 1)$ & & Dacite & Diatom clay \\
\hline & 2.90 & 147.7 & 14 & $2 \times 5$ & Light gray $(7.4 \mathrm{YR} 4.3 / 0.8)$ & & Date & Clayey calcareous diatom ooze \\
\hline & 3.08 & 176.4 & 6 & & & & - & Calcareous ooze with diatom \\
\hline 140 & 3.10 & 191.2 & 13 & $1 \times 2$ & Yellowish gray $(2.5 Y 4 / 1)$ & Black (2.9RP 2.1/1.0) & Basaltic andesite & Clay diatom ooze or diatom ooze \\
\hline 142 & 3.50 & 196.4 & 10 & $1 \times 3$ & Light gray $(2.5 \mathrm{Y} 7 / 1)$ & Light gray $(6.8 Y R \quad 4.5 / 0.5)$ & Rhyolite & Clay diatom ooze or diatom ooze \\
\hline 143 & 3.70 & 199.9 & 5 & $1 \times 6$ & Grayish yellow $(2.5 Y 7 / 2)$ & & Rhyolite & Clay diatom ooze or diatom ooze \\
\hline \multirow[t]{6}{*}{144} & 3.84 & 204.7 & 5 & $2 \times 3$ & Yellowish gray (2.5Y 5/1) & & Basaltic andesite & Clay diatom ooze or diatom ooze \\
\hline & 3.89 & 218.8 & 15 & & & & - & Clay diatom ooze or diatom ooze \\
\hline & 4.02 & 223.5 & 3 & & & & - & Clay diatom ooze or diatom ooze \\
\hline & 4.35 & 236.1 & 6 & & & & - & Clay diatom ooze or diatom ooze \\
\hline & 4.36 & 269.1 & 6 & & & & - & Clay diatom ooze or diatom ooze \\
\hline & 4.48 & 269.3 & 6 & & & & - & Clay diatom ooze or diatom ooze \\
\hline 145 & 4.50 & 271.3 & 5 & $0.5 \times 6$ & Light gray $(2.5 \mathrm{Y} 7 / 1)$ & & Rhyolite & Clay diatom ooze or diatom ooze \\
\hline 146 & 5.23 & 272.6 & 5 & $2.5 \times 5$ & Yellowish gray $(2.5 Y$ Y $6 / 1)$ & & Andesite-dacite & Clay diatom ooze or diatom ooze \\
\hline 147 & 5.80 & 296.5 & 4 & $2 \times 10$ & Grayish yellow $(2.5 \mathrm{Y} 7 / 2)$ & & Rhyolite & Clay diatom ooze or diatom ooze \\
\hline 148 & 5.81 & 320 & 8 & $2 \times 3$ & Yellowish gray $(2.5$ Y $5 / 1)$ & & Dacite & Clay diatom ooze or diatom ooze \\
\hline \multirow[t]{3}{*}{$\begin{array}{l}140 \\
149\end{array}$} & 5.85 & 321.3 & $\begin{array}{l}\circ \\
4\end{array}$ & $2 \times 5$ & Light gray $(2.5 \mathrm{Y} 8 / 1)$ & & Rhyolite & Clay diatom ooze or diatom ooze \\
\hline & 5.87 & 323.1 & 5 & & & & - & Clay diatom ooze or diatom ooze \\
\hline & 6.22 & 324 & 5 & & & & - & Clay diatom ooze or diatom ooze \\
\hline \multirow[t]{4}{*}{150} & -35 & 344.1 & - & $1 \times 5$ & Light gray $(2.5 \mathrm{Y} 7 / 1)$ & & Andesite-dacite & Diatom ooze with clay \\
\hline & $\sim 35$ & 711 & 8 & & 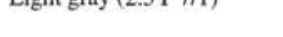 & & - & Claystone \\
\hline & -35 & 711.8 & 6 & & & & $=$ & Claystone \\
\hline & 35.00 & 713.9 & 11 & & & & $-\ldots$ & Claystone \\
\hline 152 & $>35$ & 719.4 & 6 & $1 \times 3$ & Brownish black (2.5Y 3/1) & & Basaltic andesite & Claystone \\
\hline \multirow[t]{9}{*}{153} & $>35$ & 720.1 & 15 & $3 \times 5$ & Yellowish gray (2.5Y 4/1) & Dark gray $(1.5 Y 2.5 / 1)$ & Andesite-dacite & Claystone \\
\hline & $>35$ & 721.5 & 7 & & Dark gray $(1.5 Y 2.5 / 1)$ & & - & Claystone \\
\hline & $>35$ & 721.9 & 55 & & Dark gray(1.5Y 2.5/1) & & - & Claystone \\
\hline & $>35$ & 723 & 6 & & Dark gray $(1.5 \mathrm{Y} 2.5 / 1)$ & & - & Claystone \\
\hline & $>35$ & 724.8 & 13 & & Dark gray $(1.5 \times 2.5 / 1)$ & & $=$ & Claystone \\
\hline & $>35$ & 726.5 & 52 & & Dark gray $(1.5 Y 2.5 / 1)$ & & $\overline{-}$ & Claystone \\
\hline & $>35$ & 729.9 & 32 & & Dalk gray $(1,51$ is $2.5 / 1)$ & & $=$ & Claystone \\
\hline & $>35$ & 730.3 & 32 & & & & - & Claystone \\
\hline & $>35$ & 788.5 & 51 & & Light brown brown & Black $(2.3$ Y $2.8 / 0.5)$ & - & Claystone \\
\hline
\end{tabular}

Note $--=$ data not available. 
Table 5. Representative analyses of vitric shards from Site 881 .

\begin{tabular}{|c|c|c|c|c|c|c|c|c|c|c|c|c|c|c|c|}
\hline $\begin{array}{l}\text { Hole: } \\
\text { UNE number: } \\
\text { Core, section: } \\
\text { Interval }(\mathrm{cm}) \text { : }\end{array}$ & $\begin{array}{c}881 \mathrm{~A} \\
1 \\
1 \mathrm{H}-2 \\
116-117 \\
\end{array}$ & $\begin{array}{c}881 \mathrm{~A} \\
1 \\
1 \mathrm{H}-2 \\
116-117\end{array}$ & $\begin{array}{c}881 \mathrm{~A} \\
1 \\
1 \mathrm{H}-2 \\
116-117 \\
\end{array}$ & $\begin{array}{c}881 \mathrm{~A} \\
1 \\
1 \mathrm{H}-2 \\
116-117 \\
\end{array}$ & $\begin{array}{c}881 \mathrm{~A} \\
1 \\
1 \mathrm{H}-2 \\
116-117 \\
\end{array}$ & $\begin{array}{c}881 \mathrm{~A} \\
1 \\
1 \mathrm{H}-2 \\
116-117 \\
\end{array}$ & $\begin{array}{c}881 \mathrm{~A} \\
1 \\
1 \mathrm{H}-2 \\
116-117 \\
\end{array}$ & $\begin{array}{c}881 \mathrm{~A} \\
2 \\
1 \mathrm{H}-4 \\
44-45 \\
\end{array}$ & $\begin{array}{c}881 \mathrm{~A} \\
2 \\
1 \mathrm{H}-4 \\
44-45 \\
\end{array}$ & $\begin{array}{r}881 \mathrm{~A} \\
2 \\
1 \mathrm{H}-4 \\
44-45 \\
\end{array}$ & $\begin{array}{c}881 \mathrm{~A} \\
2 \\
1 \mathrm{H}-4 \\
44-45 \\
\end{array}$ & $\begin{array}{c}881 \mathrm{~A} \\
3 \\
1 \mathrm{H}-6 \\
52-53 \\
\end{array}$ & $\begin{array}{c}881 \mathrm{~A} \\
3 \\
1 \mathrm{H}-6 \\
52-53 \\
\end{array}$ & $\begin{array}{c}881 \mathrm{~A} \\
3 \\
1 \mathrm{H}-6 \\
52-53 \\
\end{array}$ & $\begin{array}{c}881 \mathrm{~A} \\
4 \\
1 \mathrm{H}-6 \\
109-110 \\
\end{array}$ \\
\hline $\begin{array}{l}\mathrm{SiO}_{2} \\
\mathrm{TiO}_{2} \\
\mathrm{Al}_{2} \mathrm{O}_{3} \\
\mathrm{FeO}^{*} \\
\mathrm{MnO} \\
\mathrm{MgO} \\
\mathrm{CaO} \\
\mathrm{K}_{2} \mathrm{O} \\
\mathrm{Na}_{2} \mathrm{O} \\
\text { Total }\end{array}$ & $\begin{array}{c}79.46 \\
0.25 \\
11.98 \\
1.8 \\
0 \\
0 \\
1.53 \\
2.07 \\
2.91 \\
98.1\end{array}$ & $\begin{array}{r}79.48 \\
0.29 \\
11.91 \\
1.84 \\
0 \\
0 \\
1.59 \\
1.93 \\
2.97 \\
96.86\end{array}$ & $\begin{array}{c}79.67 \\
0 \\
11.98 \\
1.92 \\
0 \\
0 \\
1.5 \\
2.06 \\
2.87 \\
96.05\end{array}$ & $\begin{array}{c}79.3 \\
0.31 \\
12.05 \\
1.85 \\
0 \\
0 \\
1.57 \\
1.92 \\
3 \\
98.34\end{array}$ & $\begin{array}{c}79.82 \\
0.16 \\
11.81 \\
1.85 \\
0 \\
0 \\
1.56 \\
1.9 \\
2.9 \\
96.23\end{array}$ & $\begin{array}{c}79.72 \\
0 \\
12.08 \\
1.74 \\
0 \\
0 \\
1.5 \\
2.02 \\
2.95 \\
97.02\end{array}$ & $\begin{array}{c}74.03 \\
0 \\
18.9 \\
0.76 \\
0 \\
0.78 \\
2.15 \\
1.13 \\
1.97 \\
96.45\end{array}$ & $\begin{array}{c}79.12 \\
0 \\
12.2 \\
0.73 \\
0 \\
0 \\
0.34 \\
4.12 \\
3.49 \\
99.43\end{array}$ & $\begin{array}{c}79.23 \\
0 \\
12.51 \\
0.47 \\
0 \\
0 \\
0.37 \\
4.07 \\
3.35 \\
98.62\end{array}$ & $\begin{array}{c}79.4 \\
0 \\
12.13 \\
0.5 \\
0 \\
0 \\
0.42 \\
4.12 \\
3.44 \\
98.76\end{array}$ & $\begin{array}{c}79.33 \\
0 \\
12.31 \\
0.44 \\
0 \\
0 \\
0.38 \\
4.06 \\
3.47 \\
99.67\end{array}$ & $\begin{array}{r}75.94 \\
0.26 \\
14.81 \\
2.48 \\
0 \\
0.13 \\
2.43 \\
1.2 \\
2.74 \\
98.51\end{array}$ & $\begin{array}{c}75.82 \\
0.42 \\
14.59 \\
2.36 \\
0 \\
0.18 \\
2.37 \\
1.4 \\
2.86 \\
99.02\end{array}$ & $\begin{array}{c}76.32 \\
0.32 \\
14.48 \\
2.32 \\
0 \\
0 \\
2.3 \\
1.38 \\
2.88 \\
98.61\end{array}$ & $\begin{array}{c}77.74 \\
0.24 \\
12.88 \\
1.51 \\
0 \\
0 \\
1.7 \\
1.9 \\
4.03 \\
96.69\end{array}$ \\
\hline $\begin{array}{l}\text { Hole: } \\
\text { UNE number: } \\
\text { Core, section: } \\
\text { Interval }(\mathrm{cm}) \text { : }\end{array}$ & $\begin{array}{c}881 \mathrm{~A} \\
4 \\
1 \mathrm{H}-6 \\
109-110 \\
\end{array}$ & $\begin{array}{c}881 \mathrm{~A} \\
4 \\
1 \mathrm{H}-6 \\
109-110 \\
\end{array}$ & $\begin{array}{c}881 \mathrm{~A} \\
4 \\
1 \mathrm{H}-6 \\
109-110 \\
\end{array}$ & $\begin{array}{c}881 \mathrm{~A} \\
4 \\
1 \mathrm{H}-6 \\
109-110 \\
\end{array}$ & $\begin{array}{c}881 \mathrm{~B} \\
6 \\
2 \mathrm{H}-3 \\
56-57 \\
\end{array}$ & $\begin{array}{c}881 \mathrm{~B} \\
6 \\
2 \mathrm{H}-3 \\
56-57 \\
\end{array}$ & $\begin{array}{c}881 \mathrm{~B} \\
6 \\
2 \mathrm{H}-3 \\
56-57 \\
\end{array}$ & $\begin{array}{c}881 \mathrm{~B} \\
6 \\
2 \mathrm{H}-3 \\
56-57 \\
\end{array}$ & $\begin{array}{c}881 \mathrm{~B} \\
6 \\
2 \mathrm{H}-3 \\
56-57 \\
\end{array}$ & $\begin{array}{c}881 \mathrm{~B} \\
6 \\
2 \mathrm{H}-3 \\
56-57 \\
\end{array}$ & $\begin{array}{c}881 \mathrm{~B} \\
7 \\
2 \mathrm{H}-5 \\
149-150 \\
\end{array}$ & $\begin{array}{c}881 \mathrm{~B} \\
7 \\
2 \mathrm{H}-5 \\
149-150 \\
\end{array}$ & $\begin{array}{c}881 \mathrm{~B} \\
7 \\
2 \mathrm{H}-5 \\
149-150 \\
\end{array}$ & $\begin{array}{c}881 \mathrm{~B} \\
7 \\
2 \mathrm{H}-5 \\
149-150 \\
\end{array}$ & $\begin{array}{c}881 \mathrm{~B} \\
7 \\
2 \mathrm{H}-5 \\
149-150 \\
\end{array}$ \\
\hline $\begin{array}{l}\mathrm{SiO}_{2} \\
\mathrm{TiO}_{2} \\
\mathrm{Al}_{2} \mathrm{O}_{3} \\
\mathrm{FeO}^{*} \\
\mathrm{MnO} \\
\mathrm{MgO} \\
\mathrm{CaO} \\
\mathrm{K}_{2} \mathrm{O} \\
\mathrm{Na}_{2} \mathrm{O} \\
\text { Total }\end{array}$ & $\begin{array}{r}78.34 \\
0.22 \\
12.57 \\
1.4 \\
0 \\
0 \\
1.49 \\
2.09 \\
3.89 \\
96.29\end{array}$ & $\begin{array}{c}78.51 \\
0.18 \\
12.6 \\
1.37 \\
0 \\
0 \\
1.5 \\
2.08 \\
3.77 \\
96.21\end{array}$ & $\begin{array}{c}76.06 \\
0.34 \\
13.25 \\
2.1 \\
0 \\
0 \\
1.97 \\
1.83 \\
4.46 \\
98.61\end{array}$ & $\begin{array}{c}79.87 \\
0.13 \\
11.96 \\
1.15 \\
0 \\
0 \\
1.18 \\
2.1 \\
3.61 \\
95.13\end{array}$ & $\begin{array}{r}79.98 \\
0.24 \\
12.24 \\
0.91 \\
0.00 \\
0.00 \\
1.10 \\
2.90 \\
2.65 \\
93.75\end{array}$ & $\begin{array}{r}79.76 \\
0.21 \\
12.32 \\
1.01 \\
0.00 \\
0.00 \\
1.14 \\
2.94 \\
2.62 \\
94.29\end{array}$ & $\begin{array}{r}80.37 \\
0.00 \\
12.29 \\
0.90 \\
0.00 \\
0.00 \\
1.17 \\
2.67 \\
2.61 \\
93.48\end{array}$ & $\begin{array}{r}80.02 \\
0.27 \\
12.34 \\
0.87 \\
0.00 \\
0.00 \\
1.25 \\
2.79 \\
2.47 \\
93.50\end{array}$ & $\begin{array}{r}80.59 \\
0.00 \\
12.30 \\
0.95 \\
0.00 \\
0.00 \\
1.06 \\
2.56 \\
2.54 \\
93.34\end{array}$ & $\begin{array}{r}80.29 \\
0.00 \\
12.44 \\
0.89 \\
0.00 \\
0.00 \\
1.13 \\
2.72 \\
2.53 \\
93.49\end{array}$ & $\begin{array}{r}59.19 \\
1.31 \\
15.34 \\
10.80 \\
0.16 \\
2.04 \\
7.43 \\
1.15 \\
2.59 \\
98.75\end{array}$ & $\begin{array}{r}77.80 \\
0.39 \\
12.79 \\
1.54 \\
0.35 \\
0.00 \\
1.43 \\
2.28 \\
3.42 \\
96.15\end{array}$ & $\begin{array}{r}78.40 \\
0.16 \\
12.90 \\
1.63 \\
0.00 \\
0.00 \\
1.63 \\
2.04 \\
3.25 \\
94.12\end{array}$ & $\begin{array}{r}80.47 \\
0.00 \\
12.00 \\
1.06 \\
0.00 \\
0.00 \\
1.18 \\
2.16 \\
3.12 \\
94.70\end{array}$ & $\begin{array}{r}79.05 \\
0.17 \\
12.51 \\
1.50 \\
0.15 \\
0.00 \\
1.57 \\
2.04 \\
3.02 \\
94.98\end{array}$ \\
\hline $\begin{array}{l}\text { Hole; } \\
\text { UNE number: } \\
\text { Core, section: } \\
\text { Interval }(\mathrm{cm}) \text { : }\end{array}$ & $\begin{array}{c}881 \mathrm{~B} \\
7 \\
2 \mathrm{H}-5 \\
149-150 \\
\end{array}$ & $\begin{array}{c}881 \mathrm{~B} \\
7 \\
2 \mathrm{H}-5 \\
149-150 \\
\end{array}$ & $\begin{array}{c}881 \mathrm{~B} \\
8 \\
3 \mathrm{H}-1 \\
2-3 \\
\end{array}$ & $\begin{array}{c}881 \mathrm{~B} \\
8 \\
3 \mathrm{H}-1 \\
2-3 \\
\end{array}$ & $\begin{array}{c}881 \mathrm{~B} \\
8 \\
3 \mathrm{H}-1 \\
2-3 \\
\end{array}$ & $\begin{array}{c}881 \mathrm{~B} \\
8 \\
3 \mathrm{H}-1 \\
2-3 \\
\end{array}$ & $\begin{array}{c}881 \mathrm{~B} \\
8 \\
3 \mathrm{H}-1 \\
2-3 \\
\end{array}$ & $\begin{array}{c}881 \mathrm{~B} \\
8 \\
3 \mathrm{H}-1 \\
2-3 \\
\end{array}$ & $\begin{array}{c}881 \mathrm{~B} \\
8 \\
3 \mathrm{H}-1 \\
2-3 \\
\end{array}$ & $\begin{array}{c}881 \mathrm{~B} \\
9 \\
3 \mathrm{H}-1 \\
35-36 \\
\end{array}$ & $\begin{array}{c}881 \mathrm{~B} \\
9 \\
3 \mathrm{H}-1 \\
35-36 \\
\end{array}$ & $\begin{array}{c}881 \mathrm{~B} \\
9 \\
3 \mathrm{H}-1 \\
35-36 \\
\end{array}$ & $\begin{array}{c}881 \mathrm{~B} \\
9 \\
3 \mathrm{H}-1 \\
35-36 \\
\end{array}$ & $\begin{array}{c}881 \mathrm{~B} \\
9 \\
3 \mathrm{H}-1 \\
35-36 \\
\end{array}$ & $\begin{array}{c}881 \mathrm{~B} \\
9 \\
3 \mathrm{H}-1 \\
35-36 \\
\end{array}$ \\
\hline $\begin{array}{l}\mathrm{SiO}_{2} \\
\mathrm{TiO}_{2} \\
\mathrm{Al}_{2} \mathrm{O}_{3} \\
\mathrm{FeO}^{*} \\
\mathrm{MnO} \\
\mathrm{MgO} \\
\mathrm{CaO} \\
\mathrm{K}_{2} \mathrm{O} \\
\mathrm{Na}_{2} \mathrm{O} \\
\text { Total }\end{array}$ & $\begin{array}{r}77.96 \\
0.19 \\
12.71 \\
1.56 \\
0.22 \\
0.00 \\
1.84 \\
2.08 \\
3.44 \\
95.14\end{array}$ & $\begin{array}{r}78.54 \\
0.27 \\
12.74 \\
1.51 \\
0.00 \\
0.00 \\
1.69 \\
2.07 \\
3.19 \\
94.83\end{array}$ & $\begin{array}{r}81.93 \\
0.00 \\
12.53 \\
0.99 \\
0.00 \\
0.00 \\
1.06 \\
2.24 \\
1.25 \\
94.14\end{array}$ & $\begin{array}{r}79.65 \\
0.27 \\
13.09 \\
1.45 \\
0.00 \\
0.00 \\
1.70 \\
1.89 \\
1.95 \\
94.63\end{array}$ & $\begin{array}{r}80.47 \\
0.00 \\
12.37 \\
0.98 \\
0.00 \\
0.00 \\
1.14 \\
2.65 \\
2.39 \\
94.05\end{array}$ & $\begin{array}{r}79.99 \\
0.25 \\
12.72 \\
1.47 \\
0.00 \\
0.00 \\
1.57 \\
1.85 \\
2.13 \\
93.82\end{array}$ & $\begin{array}{r}79.13 \\
0.27 \\
12.97 \\
1.58 \\
0.00 \\
0.00 \\
1.81 \\
1.92 \\
2.31 \\
92.00\end{array}$ & $\begin{array}{r}81.15 \\
0.16 \\
12.07 \\
1.32 \\
0.00 \\
0.00 \\
1.16 \\
2.05 \\
2.10 \\
93.86\end{array}$ & $\begin{array}{r}81.10 \\
0.13 \\
12.19 \\
1.04 \\
0.00 \\
0.00 \\
1.21 \\
2.00 \\
2.32 \\
93.70\end{array}$ & $\begin{array}{r}77.69 \\
0.23 \\
12.90 \\
1.57 \\
0.00 \\
0.00 \\
1.78 \\
2.08 \\
3.75 \\
94.42\end{array}$ & $\begin{array}{r}78.20 \\
0.15 \\
12.97 \\
1.58 \\
0.00 \\
0.00 \\
1.59 \\
1.90 \\
3.60 \\
97.72\end{array}$ & $\begin{array}{r}79.78 \\
0.16 \\
11.84 \\
1.10 \\
0.00 \\
0.00 \\
1.24 \\
2.15 \\
3.74 \\
99.29\end{array}$ & $\begin{array}{r}79.96 \\
0.27 \\
11.63 \\
1.23 \\
0.00 \\
0.00 \\
1.17 \\
2.17 \\
3.57 \\
97.96\end{array}$ & $\begin{array}{r}79.88 \\
0.15 \\
11.65 \\
1.13 \\
0.00 \\
0.00 \\
1.15 \\
2.44 \\
3.60 \\
97.49\end{array}$ & $\begin{array}{r}79.95 \\
0.00 \\
11.96 \\
1.01 \\
0.00 \\
0.00 \\
1.01 \\
2.75 \\
3.31 \\
95.75\end{array}$ \\
\hline $\begin{array}{l}\text { Hole: } \\
\text { UNE number: } \\
\text { Core, section: } \\
\text { Interval }(\mathrm{cm}):\end{array}$ & $\begin{array}{l}881 \mathrm{~B} \\
10 \\
3 \mathrm{H}-5 \\
19-20\end{array}$ & $\begin{array}{c}881 \mathrm{~B} \\
10 \\
3 \mathrm{H}-5 \\
19-20\end{array}$ & $\begin{array}{c}881 \mathrm{~B} \\
11 \\
3 \mathrm{H}-6 \\
144-145\end{array}$ & $\begin{array}{c}881 \mathrm{~B} \\
11 \\
3 \mathrm{H}-6 \\
144-145 \\
\end{array}$ & $\begin{array}{c}881 \mathrm{~B} \\
11 \\
3 \mathrm{H}-6 \\
144-145 \\
\end{array}$ & $\begin{array}{c}881 \mathrm{~B} \\
11 \\
3 \mathrm{H}-6 \\
144-145 \\
\end{array}$ & $\begin{array}{c}881 \mathrm{~B} \\
11 \\
3 \mathrm{H}-6 \\
144-145 \\
\end{array}$ & $\begin{array}{c}881 \mathrm{~B} \\
11 \\
3 \mathrm{H}-6 \\
144-145 \\
\end{array}$ & $\begin{array}{c}881 \mathrm{~B} \\
12 \\
4 \mathrm{H}-1 \\
71-12\end{array}$ & $\begin{array}{c}881 \mathrm{~B} \\
12 \\
4 \mathrm{H}-1 \\
71-12\end{array}$ & $\begin{array}{c}881 \mathrm{~B} \\
12 \\
4 \mathrm{H}-1 \\
71-12\end{array}$ & $\begin{array}{l}881 \mathrm{~B} \\
12 \\
4 \mathrm{H}-1 \\
71-12\end{array}$ & $\begin{array}{c}881 \mathrm{~B} \\
13 \\
5 \mathrm{H}-3 \\
98-99\end{array}$ & $\begin{array}{c}881 \mathrm{~B} \\
14 \\
6 \mathrm{H}-2 \\
103-104\end{array}$ & $\begin{array}{c}881 \mathrm{~B} \\
14 \\
6 \mathrm{H}-2 \\
103-104\end{array}$ \\
\hline $\begin{array}{l}\mathrm{SiO}_{2} \\
\mathrm{TiO}_{2} \\
\mathrm{Al}_{2} \mathrm{O}_{3} \\
\mathrm{FeO}^{*} \\
\mathrm{MnO} \\
\mathrm{MgO} \\
\mathrm{CaO} \\
\mathrm{K}_{2} \mathrm{O} \\
\mathrm{Na}_{2} \mathrm{O} \\
\text { Total }\end{array}$ & $\begin{array}{r}76.11 \\
0.53 \\
13.25 \\
2.73 \\
0.00 \\
0.00 \\
1.98 \\
1.60 \\
4.17 \\
96.65\end{array}$ & $\begin{array}{r}71.64 \\
0.29 \\
14.72 \\
3.00 \\
0.00 \\
0.16 \\
1.59 \\
3.46 \\
5.15 \\
98.40\end{array}$ & $\begin{array}{r}79.86 \\
0.00 \\
12.52 \\
0.78 \\
0.00 \\
0.00 \\
0.97 \\
3.28 \\
2.59 \\
96.28\end{array}$ & $\begin{array}{r}79.32 \\
0.15 \\
12.58 \\
1.05 \\
0.00 \\
0.00 \\
0.89 \\
3.39 \\
2.62 \\
96.62\end{array}$ & $\begin{array}{r}79.33 \\
0.00 \\
12.58 \\
0.88 \\
0.00 \\
0.00 \\
0.90 \\
3.48 \\
2.84 \\
96.11\end{array}$ & $\begin{array}{c}80.09 \\
0 \\
12.32 \\
0.74 \\
0 \\
0 \\
0.9 \\
3.43 \\
2.52 \\
94.57\end{array}$ & $\begin{array}{c}79.47 \\
0 \\
12.64 \\
0.89 \\
0 \\
0 \\
0.88 \\
3.46 \\
2.73 \\
95.01\end{array}$ & $\begin{array}{c}79.77 \\
0 \\
12.25 \\
0.93 \\
0 \\
0 \\
0.96 \\
3.36 \\
2.73 \\
97.25\end{array}$ & $\begin{array}{c}80.42 \\
0.22 \\
11.96 \\
0.95 \\
0 \\
0 \\
0.96 \\
3.31 \\
2.18 \\
96.74\end{array}$ & $\begin{array}{c}80.32 \\
0.18 \\
12.25 \\
0.94 \\
0 \\
0 \\
1.02 \\
3.14 \\
2.14 \\
97.53\end{array}$ & $\begin{array}{c}80.72 \\
0 \\
12.02 \\
0.89 \\
0 \\
0 \\
0.87 \\
3.13 \\
2.38 \\
97.46\end{array}$ & $\begin{array}{c}79.75 \\
0.19 \\
12.36 \\
1.07 \\
0 \\
0 \\
1.15 \\
3.02 \\
2.46 \\
97.99\end{array}$ & $\begin{array}{c}66.39 \\
0.39 \\
19.61 \\
1.14 \\
0 \\
0 \\
0.71 \\
4.61 \\
7.15 \\
100.22\end{array}$ & $\begin{array}{c}69.25 \\
0.73 \\
16 \\
3.43 \\
0 \\
0 \\
2.98 \\
2.48 \\
5.13 \\
98.54\end{array}$ & $\begin{array}{r}76.55 \\
0.23 \\
13.56 \\
1.84 \\
0 \\
0 \\
1.29 \\
2.12 \\
4.41 \\
98.14\end{array}$ \\
\hline
\end{tabular}


Table 5 (continued),

\begin{tabular}{|c|c|c|c|c|c|c|c|c|c|c|c|c|c|c|c|}
\hline $\begin{array}{l}\text { Hole: } \\
\text { UNE number: } \\
\text { Core, section: } \\
\text { Interval }(\mathrm{cm}):\end{array}$ & $\begin{array}{c}881 \mathrm{~B} \\
14 \\
6 \mathrm{H}-2 \\
103-104 \\
\end{array}$ & $\begin{array}{c}881 \mathrm{~B} \\
14 \\
6 \mathrm{H}-2 \\
103-104\end{array}$ & $\begin{array}{c}881 \mathrm{~B} \\
15 \\
6 \mathrm{H}-3 \\
102-103 \\
\end{array}$ & $\begin{array}{c}881 \mathrm{~B} \\
15 \\
6 \mathrm{H}-3 \\
102-103 \\
\end{array}$ & $\begin{array}{c}881 \mathrm{~B} \\
15 \\
6 \mathrm{H}-3 \\
102-103 \\
\end{array}$ & $\begin{array}{c}881 \mathrm{~B} \\
15 \\
6 \mathrm{H}-3 \\
102-103 \\
\end{array}$ & $\begin{array}{c}881 \mathrm{~B} \\
15 \\
6 \mathrm{H}-3 \\
102-103 \\
\end{array}$ & $\begin{array}{c}881 \mathrm{~B} \\
15 \\
6 \mathrm{H}-3 \\
102-103 \\
\end{array}$ & $\begin{array}{c}881 \mathrm{~B} \\
16 \\
6 \mathrm{H}-6 \\
106-107 \\
\end{array}$ & $\begin{array}{c}881 \mathrm{~B} \\
16 \\
6 \mathrm{H}-6 \\
106-107 \\
\end{array}$ & $\begin{array}{c}881 \mathrm{~B} \\
16 \\
6 \mathrm{H}-6 \\
106-107\end{array}$ & $\begin{array}{c}881 \mathrm{~B} \\
16 \\
6 \mathrm{H}-6 \\
106-107 \\
\end{array}$ & $\begin{array}{c}881 \mathrm{~B} \\
16 \\
6 \mathrm{H}-6 \\
106-107 \\
\end{array}$ & $\begin{array}{c}881 \mathrm{~B} \\
16 \\
6 \mathrm{H}-6 \\
106-107\end{array}$ & $\begin{array}{c}881 \mathrm{~B} \\
16 \\
6 \mathrm{H}-6 \\
106-107\end{array}$ \\
\hline $\begin{array}{l}\mathrm{SiO}_{2} \\
\mathrm{TiO}_{2} \\
\mathrm{Al}_{2} \mathrm{O}_{3} \\
\mathrm{FeO}^{*} \\
\mathrm{MnO} \\
\mathrm{MgO} \\
\mathrm{CaO} \\
\mathrm{K}_{2} \mathrm{O} \\
\mathrm{Na}_{2} \mathrm{O} \\
\mathrm{Total}\end{array}$ & $\begin{array}{c}77.61 \\
0 \\
12.84 \\
1.21 \\
0 \\
0 \\
1.28 \\
3.32 \\
3.74 \\
99.41\end{array}$ & $\begin{array}{c}75.57 \\
0.31 \\
13.61 \\
2.08 \\
0 \\
0 \\
1.33 \\
2.44 \\
4.65 \\
96.35\end{array}$ & $\begin{array}{c}74.8 \\
0.59 \\
14.51 \\
2.62 \\
0 \\
0.23 \\
2.03 \\
2.35 \\
2.87 \\
97.03\end{array}$ & $\begin{array}{c}74.07 \\
0.49 \\
14.55 \\
2.7 \\
0 \\
0.3 \\
2.09 \\
2.31 \\
3.49 \\
96.2\end{array}$ & $\begin{array}{r}74.35 \\
0.63 \\
14.54 \\
2.85 \\
0.15 \\
0.32 \\
2.05 \\
2.22 \\
2.91 \\
96.33\end{array}$ & $\begin{array}{r}75.13 \\
0.56 \\
13.84 \\
3.02 \\
0.13 \\
0.13 \\
1.65 \\
2.61 \\
2.93 \\
96.66\end{array}$ & $\begin{array}{r}74.22 \\
0.54 \\
14.59 \\
2.88 \\
0.14 \\
0.29 \\
2.11 \\
2.26 \\
2.96 \\
97.57\end{array}$ & $\begin{array}{r}73.43 \\
0.51 \\
14.47 \\
3.05 \\
0.2 \\
0.36 \\
2.31 \\
2.33 \\
3.34 \\
97.7\end{array}$ & $\begin{array}{r}79.71 \\
0.31 \\
12.23 \\
1.96 \\
0 \\
0.16 \\
2.35 \\
0.67 \\
2.61 \\
95.66\end{array}$ & $\begin{array}{c}80.19 \\
0.35 \\
12.17 \\
2.13 \\
0 \\
0 \\
2.32 \\
0.75 \\
2.1 \\
94.83\end{array}$ & $\begin{array}{r}79.37 \\
0.36 \\
12.16 \\
2.15 \\
0 \\
0.15 \\
2.38 \\
0.79 \\
2.63 \\
95.57\end{array}$ & $\begin{array}{c}79.4 \\
0.35 \\
11.8 \\
2.23 \\
0 \\
0.14 \\
2.53 \\
0.75 \\
2.8 \\
94.94\end{array}$ & $\begin{array}{c}80.39 \\
0.23 \\
12.03 \\
1.96 \\
0 \\
0 \\
2.26 \\
0.69 \\
2.38 \\
95.47\end{array}$ & $\begin{array}{c}79.4 \\
0.34 \\
11.95 \\
2.24 \\
0 \\
0.26 \\
2.4 \\
0.75 \\
2.67 \\
96.1\end{array}$ & $\begin{array}{r}79.58 \\
0.28 \\
12.04 \\
1.99 \\
0 \\
0.19 \\
2.38 \\
0.82 \\
2.71 \\
95.95\end{array}$ \\
\hline $\begin{array}{l}\text { Hole: } \\
\text { UNE number: } \\
\text { Core, section: } \\
\text { Interval }(\mathrm{cm}) \text { : }\end{array}$ & $\begin{array}{c}881 \mathrm{~B} \\
17 \\
7 \mathrm{H}-5 \\
115-116\end{array}$ & $\begin{array}{c}881 \mathrm{~B} \\
17 \\
7 \mathrm{H}-5 \\
115-116 \\
\end{array}$ & $\begin{array}{c}881 \mathrm{~B} \\
17 \\
7 \mathrm{H}-5 \\
115-116\end{array}$ & $\begin{array}{c}881 \mathrm{~B} \\
17 \\
7 \mathrm{H}-5 \\
115-116\end{array}$ & $\begin{array}{c}881 \mathrm{~B} \\
17 \\
7 \mathrm{H}-5 \\
115-116\end{array}$ & $\begin{array}{c}881 \mathrm{~B} \\
17 \\
7 \mathrm{H}-5 \\
115-116\end{array}$ & $\begin{array}{c}881 \mathrm{~B} \\
18 \\
7 \mathrm{H}-6 \\
116-117\end{array}$ & $\begin{array}{c}881 \mathrm{~B} \\
18 \\
7 \mathrm{H}-6 \\
116-117\end{array}$ & $\begin{array}{c}881 \mathrm{~B} \\
18 \\
7 \mathrm{H}-6 \\
116-117\end{array}$ & $\begin{array}{c}881 \mathrm{~B} \\
18 \\
7 \mathrm{H}-6 \\
116-117\end{array}$ & $\begin{array}{c}881 \mathrm{~B} \\
18 \\
7 \mathrm{H}-6 \\
116-117\end{array}$ & $\begin{array}{c}881 \mathrm{~B} \\
18 \\
7 \mathrm{H}-6 \\
116-117\end{array}$ & $\begin{array}{c}881 \mathrm{~B} \\
19 \\
9 \mathrm{H}-1 \\
43-44\end{array}$ & $\begin{array}{c}881 \mathrm{~B} \\
19 \\
9 \mathrm{H}-1 \\
43-44 \\
\end{array}$ & $\begin{array}{c}881 \mathrm{~B} \\
19 \\
9 \mathrm{H}-1 \\
43-44\end{array}$ \\
\hline $\begin{array}{l}\mathrm{SiO}_{2} \\
\mathrm{TiO}_{2} \\
\mathrm{Al}_{2} \mathrm{O}_{3} \\
\mathrm{FeO}^{*} \\
\mathrm{MnO} \\
\mathrm{MgO} \\
\mathrm{CaO} \\
\mathrm{K}_{2} \mathrm{O} \\
\mathrm{Na}_{2} \mathrm{O} \\
\text { Total }\end{array}$ & $\begin{array}{c}78.95 \\
0 \\
12.45 \\
0.36 \\
0 \\
0 \\
0.45 \\
4.62 \\
3.16 \\
96.59\end{array}$ & $\begin{array}{c}78.39 \\
0 \\
12.66 \\
0.66 \\
0 \\
0 \\
0.49 \\
4.5 \\
3.3 \\
97.05\end{array}$ & $\begin{array}{c}78.74 \\
0 \\
12.68 \\
0.8 \\
0 \\
0 \\
0.81 \\
3.56 \\
3.41 \\
96.68\end{array}$ & $\begin{array}{c}78.38 \\
0 \\
12.81 \\
0.44 \\
0 \\
0 \\
0.54 \\
4.48 \\
3.34 \\
97.1\end{array}$ & $\begin{array}{c}78.43 \\
0 \\
12.81 \\
0.5 \\
0 \\
0 \\
0.43 \\
4.63 \\
3.21 \\
96.41\end{array}$ & $\begin{array}{c}79.14 \\
0 \\
12.59 \\
0.43 \\
0 \\
0 \\
0.39 \\
4.4 \\
3.05 \\
95.36\end{array}$ & $\begin{array}{l}78.5 \\
0 \\
12.62 \\
0.42 \\
0 \\
0 \\
0.46 \\
4.53 \\
3.46 \\
99.63\end{array}$ & $\begin{array}{c}79.64 \\
0.14 \\
12.89 \\
0.5 \\
0 \\
0 \\
0.43 \\
4.12 \\
2.28 \\
96.65\end{array}$ & $\begin{array}{c}79.6 \\
0 \\
12.71 \\
0.48 \\
0 \\
0 \\
0.38 \\
4.22 \\
2.61 \\
97.53\end{array}$ & $\begin{array}{c}79.83 \\
0 \\
12.87 \\
0.53 \\
0 \\
0 \\
0.38 \\
4.17 \\
2.22 \\
97.08\end{array}$ & $\begin{array}{c}79.84 \\
0 \\
12.79 \\
0.57 \\
0 \\
0 \\
0.47 \\
3.86 \\
2.47 \\
97.49\end{array}$ & $\begin{array}{c}79.62 \\
0 \\
12.82 \\
0.59 \\
0 \\
0 \\
0.42 \\
4.22 \\
2.32 \\
97.25\end{array}$ & $\begin{array}{c}79.65 \\
0 \\
11.85 \\
0.87 \\
0 \\
0 \\
1.07 \\
3.29 \\
3.27 \\
96.09\end{array}$ & $\begin{array}{c}79.37 \\
0 \\
12.36 \\
0.97 \\
0 \\
0 \\
1 \\
3.31 \\
2.99 \\
96.49\end{array}$ & $\begin{array}{c}79.29 \\
0 \\
12.17 \\
0.95 \\
0 \\
0 \\
1.08 \\
3.27 \\
3.24 \\
95.24\end{array}$ \\
\hline $\begin{array}{l}\text { Hole: } \\
\text { UNE number: } \\
\text { Core, section: } \\
\text { Interval }(\mathrm{cm}) \text { : }\end{array}$ & $\begin{array}{c}881 \mathrm{~B} \\
19 \\
9 \mathrm{H}-1 \\
43-44 \\
\end{array}$ & $\begin{array}{c}881 \mathrm{~B} \\
19 \\
9 \mathrm{H}-1 \\
43-44 \\
\end{array}$ & $\begin{array}{c}881 \mathrm{~B} \\
19 \\
9 \mathrm{H}-1 \\
43-44 \\
\end{array}$ & $\begin{array}{c}881 \mathrm{~B} \\
19 \\
9 \mathrm{H}-1 \\
43-44 \\
\end{array}$ & $\begin{array}{c}881 \mathrm{~B} \\
21 \\
10 \mathrm{H}-5 \\
69-70 \\
\end{array}$ & $\begin{array}{c}881 \mathrm{~B} \\
21 \\
10 \mathrm{H}-5 \\
69-70 \\
\end{array}$ & $\begin{array}{c}881 \mathrm{~B} \\
21 \\
10 \mathrm{H}-5 \\
69-70 \\
\end{array}$ & $\begin{array}{c}881 \mathrm{~B} \\
23 \\
10 \mathrm{H}-6 \\
8-9 \\
\end{array}$ & $\begin{array}{c}881 \mathrm{~B} \\
23 \\
10 \mathrm{H}-6 \\
8-9 \\
\end{array}$ & $\begin{array}{c}881 \mathrm{~B} \\
23 \\
10 \mathrm{H}-6 \\
8-9 \\
\end{array}$ & $\begin{array}{c}881 \mathrm{~B} \\
23 \\
10 \mathrm{H}-6 \\
8-9 \\
\end{array}$ & $\begin{array}{c}881 \mathrm{~B} \\
23 \\
10 \mathrm{H}-6 \\
8-9 \\
\end{array}$ & $\begin{array}{c}881 \mathrm{~B} \\
23 \\
10 \mathrm{H}-6 \\
8-9 \\
\end{array}$ & $\begin{array}{c}881 \mathrm{~B} \\
25 \\
11 \mathrm{H}-1 \\
110-111 \\
\end{array}$ & $\begin{array}{c}881 \mathrm{~B} \\
25 \\
11 \mathrm{H}-1 \\
110-111 \\
\end{array}$ \\
\hline $\begin{array}{l}\mathrm{SiO}_{2} \\
\mathrm{TiO}_{2} \\
\mathrm{Al}_{2} \mathrm{O}_{3} \\
\mathrm{FeO}^{*} \\
\mathrm{MnO} \\
\mathrm{MgO} \\
\mathrm{CaO} \\
\mathrm{K}_{2} \mathrm{O} \\
\mathrm{Na}_{2} \mathrm{O} \\
\text { Total }\end{array}$ & $\begin{array}{c}79.26 \\
0 \\
12.11 \\
0.93 \\
0 \\
0 \\
1.04 \\
3.33 \\
3.34 \\
96.64\end{array}$ & $\begin{array}{c}78.99 \\
0 \\
12.18 \\
0.9 \\
0 \\
0 \\
1.18 \\
3.36 \\
3.39 \\
96.1\end{array}$ & $\begin{array}{c}79.03 \\
0 \\
12.33 \\
1.08 \\
0 \\
0 \\
1.06 \\
3.29 \\
3.21 \\
95.74\end{array}$ & $\begin{array}{c}79.07 \\
0 \\
12.17 \\
1.01 \\
0 \\
0 \\
1.07 \\
3.28 \\
3.4 \\
96.27\end{array}$ & $\begin{array}{c}71.09 \\
0.61 \\
15.05 \\
3.7 \\
0 \\
0.5 \\
2.93 \\
2.12 \\
4.01 \\
95.04\end{array}$ & $\begin{array}{r}63.43 \\
1.55 \\
14.47 \\
7.28 \\
0.16 \\
2.98 \\
5.48 \\
1.55 \\
3.1 \\
98.15\end{array}$ & $\begin{array}{c}69.9 \\
0.72 \\
15.33 \\
4.09 \\
0 \\
0.7 \\
3.08 \\
2.05 \\
4.12 \\
96.55\end{array}$ & $\begin{array}{r}66.89 \\
0.99 \\
14.37 \\
5.92 \\
0 \\
0.99 \\
3.4 \\
4.46 \\
2.99 \\
97.81\end{array}$ & $\begin{array}{r}72.04 \\
0.61 \\
14.18 \\
4.52 \\
0 \\
0.49 \\
3.32 \\
1.68 \\
3.17 \\
96.94\end{array}$ & $\begin{array}{c}77.42 \\
0.28 \\
12.86 \\
2.65 \\
0 \\
0 \\
1.77 \\
1.91 \\
3.11 \\
96.77\end{array}$ & $\begin{array}{c}70.36 \\
0.78 \\
14.47 \\
4.16 \\
0 \\
0.76 \\
3.15 \\
2.81 \\
3.5 \\
96.08\end{array}$ & $\begin{array}{c}80.08 \\
0.2 \\
12.23 \\
1.66 \\
0 \\
0.14 \\
2.1 \\
0.91 \\
2.68 \\
96.28\end{array}$ & $\begin{array}{r}73.01 \\
1.32 \\
13.24 \\
3.61 \\
0 \\
0 \\
2.11 \\
3.18 \\
3.53 \\
97.76\end{array}$ & $\begin{array}{c}78.95 \\
0.42 \\
11.87 \\
1.9 \\
0 \\
0 \\
0.54 \\
3.02 \\
3.29 \\
96.35\end{array}$ & $\begin{array}{c}73.58 \\
0.74 \\
13.76 \\
2.94 \\
0 \\
0.4 \\
2.69 \\
2.46 \\
3.43 \\
96.53\end{array}$ \\
\hline $\begin{array}{l}\text { Hole: } \\
\text { UNE number: } \\
\text { Core, section: } \\
\text { Interval }(\mathrm{cm}):\end{array}$ & $\begin{array}{c}881 \mathrm{~B} \\
25 \\
11 \mathrm{H}-1 \\
110-111\end{array}$ & $\begin{array}{c}881 \mathrm{~B} \\
25 \\
11 \mathrm{H}-1 \\
110-111\end{array}$ & $\begin{array}{c}881 \mathrm{~B} \\
25 \\
11 \mathrm{H}-1 \\
110-111\end{array}$ & $\begin{array}{c}881 \mathrm{~B} \\
25 \\
11 \mathrm{H}-1 \\
110-111\end{array}$ & $\begin{array}{c}881 \mathrm{~B} \\
25 \\
11 \mathrm{H}-1 \\
110-111\end{array}$ & $\begin{array}{c}881 \mathrm{~B} \\
27 \\
11 \mathrm{H}-4 \\
49-50\end{array}$ & $\begin{array}{c}881 \mathrm{~B} \\
27 \\
11 \mathrm{H}-4 \\
49-50\end{array}$ & $\begin{array}{c}881 \mathrm{~B} \\
27 \\
11 \mathrm{H}-4 \\
49-50\end{array}$ & $\begin{array}{c}881 \mathrm{~B} \\
27 \\
11 \mathrm{H}-4 \\
49-50\end{array}$ & $\begin{array}{c}881 \mathrm{~B} \\
27 \\
11 \mathrm{H}-4 \\
49-50\end{array}$ & $\begin{array}{l}881 \mathrm{~B} \\
28 \\
11 \mathrm{H}-4 \\
59-60\end{array}$ & $\begin{array}{l}881 \mathrm{~B} \\
28 \\
11 \mathrm{H}-4 \\
59-60\end{array}$ & $\begin{array}{c}881 \mathrm{~B} \\
28 \\
11 \mathrm{H}-4 \\
59-60\end{array}$ & $\begin{array}{c}881 \mathrm{~B} \\
29 \\
12 \mathrm{H}-1 \\
5-7\end{array}$ & $\begin{array}{c}881 \mathrm{~B} \\
29 \\
12 \mathrm{H}-1 \\
5-7\end{array}$ \\
\hline $\begin{array}{l}\mathrm{SiO}_{2} \\
\mathrm{TiO}_{2} \\
\mathrm{Al}_{2} \mathrm{O}_{3} \\
\mathrm{FeO}_{3} \\
\mathrm{MnO} \\
\mathrm{MgO} \\
\mathrm{CaO} \\
\mathrm{K}_{2} \mathrm{O} \\
\mathrm{Na}_{2} \mathrm{O} \\
\text { Total }\end{array}$ & $\begin{array}{r}75.38 \\
0.62 \\
13.42 \\
2.48 \\
0 \\
0.25 \\
2.06 \\
2.52 \\
3.26 \\
95.68\end{array}$ & $\begin{array}{c}75.79 \\
0.47 \\
13.39 \\
2.32 \\
0 \\
0 \\
1.85 \\
2.64 \\
3.53 \\
96.83\end{array}$ & $\begin{array}{c}74.84 \\
0.62 \\
13.51 \\
2.57 \\
0 \\
0.26 \\
2.01 \\
2.69 \\
3.5 \\
96.05\end{array}$ & $\begin{array}{r}74.84 \\
0.56 \\
13.59 \\
2.64 \\
0 \\
0.19 \\
2.23 \\
2.51 \\
3.43 \\
95.65\end{array}$ & $\begin{array}{c}74.98 \\
0.56 \\
13.6 \\
2.64 \\
0 \\
0 \\
2.09 \\
2.73 \\
3.4 \\
96.16\end{array}$ & $\begin{array}{r}78.16 \\
0.24 \\
12.75 \\
1.82 \\
0 \\
0 \\
1.69 \\
2.02 \\
3.32 \\
95.48\end{array}$ & $\begin{array}{c}78.75 \\
0.29 \\
12.6 \\
1.82 \\
0 \\
0 \\
1.75 \\
2.01 \\
2.79 \\
94.84\end{array}$ & $\begin{array}{c}78.27 \\
0.28 \\
12.97 \\
1.7 \\
0 \\
0 \\
1.65 \\
2.11 \\
3.02 \\
96.43\end{array}$ & $\begin{array}{r}75.56 \\
0.51 \\
13.52 \\
2.59 \\
0 \\
0.18 \\
2.39 \\
2.09 \\
3.17 \\
95.37\end{array}$ & $\begin{array}{c}77.77 \\
0.23 \\
12.51 \\
1.67 \\
0 \\
0 \\
1.63 \\
2.22 \\
3.97 \\
97.19\end{array}$ & $\begin{array}{c}76.9 \\
0.23 \\
13.61 \\
3.19 \\
0 \\
0 \\
2.76 \\
1 \\
2.32 \\
92.73\end{array}$ & $\begin{array}{c}76.76 \\
0.24 \\
13.73 \\
2.96 \\
0 \\
0 \\
2.8 \\
1.14 \\
2.37 \\
92.95\end{array}$ & $\begin{array}{c}76.83 \\
0.2 \\
13.89 \\
2.74 \\
0 \\
0 \\
2.76 \\
0.95 \\
2.63 \\
92.17\end{array}$ & $\begin{array}{c}78.88 \\
0.34 \\
12.37 \\
2.25 \\
0 \\
0 \\
2.24 \\
0.96 \\
2.96 \\
96.76\end{array}$ & $\begin{array}{c}79.59 \\
0.31 \\
11.96 \\
2.18 \\
0 \\
0 \\
2.2 \\
1.04 \\
2.72 \\
94.14\end{array}$ \\
\hline
\end{tabular}


Table 5 (continued).

\begin{tabular}{|c|c|c|c|c|c|c|c|c|c|c|c|c|c|c|c|}
\hline $\begin{array}{l}\text { Hole: } \\
\text { UNE number: } \\
\text { Core, section: } \\
\text { Interval }(\mathrm{cm}) \text { : }\end{array}$ & $\begin{array}{c}881 \mathrm{~B} \\
29 \\
12 \mathrm{H}-1 \\
5-7 \\
\end{array}$ & $\begin{array}{c}881 \mathrm{~B} \\
29 \\
12 \mathrm{H}-1 \\
5-7 \\
\end{array}$ & $\begin{array}{c}881 \mathrm{~B} \\
29 \\
12 \mathrm{H}-1 \\
5-7 \\
\end{array}$ & $\begin{array}{c}881 \mathrm{~B} \\
29 \\
12 \mathrm{H}-1 \\
5-7\end{array}$ & $\begin{array}{c}881 \mathrm{~B} \\
29 \\
12 \mathrm{H}-1 \\
5-7 \\
\end{array}$ & $\begin{array}{c}881 \mathrm{~B} \\
30 \\
12 \mathrm{H}-1 \\
62-63 \\
\end{array}$ & $\begin{array}{c}881 \mathrm{~B} \\
30 \\
12 \mathrm{H}-1 \\
62-63 \\
\end{array}$ & $\begin{array}{c}881 \mathrm{~B} \\
30 \\
12 \mathrm{H}-1 \\
62-63 \\
\end{array}$ & $\begin{array}{c}881 \mathrm{~B} \\
30 \\
12 \mathrm{H}-1 \\
62-63 \\
\end{array}$ & $\begin{array}{c}881 \mathrm{~B} \\
30 \\
12 \mathrm{H}-1 \\
62-63 \\
\end{array}$ & $\begin{array}{c}881 \mathrm{~B} \\
30 \\
12 \mathrm{H}-1 \\
62-63 \\
\end{array}$ & $\begin{array}{c}881 \mathrm{~B} \\
31 \\
12 \mathrm{H}-1 \\
140-141 \\
\end{array}$ & $\begin{array}{c}881 \mathrm{~B} \\
31 \\
12 \mathrm{H}-1 \\
140-141 \\
\end{array}$ & $\begin{array}{c}881 \mathrm{~B} \\
31 \\
12 \mathrm{H}-1 \\
140-141 \\
\end{array}$ & $\begin{array}{c}881 \mathrm{~B} \\
31 \\
12 \mathrm{H}-1 \\
140-141\end{array}$ \\
\hline $\begin{array}{l}\mathrm{SiO}_{2} \\
\mathrm{TiO}_{2} \\
\mathrm{Al}_{2} \mathrm{O}_{3} \\
\mathrm{FeO}^{*} \\
\mathrm{MnO} \\
\mathrm{MgO} \\
\mathrm{CaO} \\
\mathrm{K}_{2} \mathrm{O} \\
\mathrm{Na}_{2} \mathrm{O} \\
\text { Total }\end{array}$ & $\begin{array}{c}78.95 \\
0.14 \\
13.26 \\
1.63 \\
0 \\
0 \\
2.15 \\
0.95 \\
2.92 \\
95.59\end{array}$ & $\begin{array}{c}80.14 \\
0.26 \\
11.78 \\
2.41 \\
0 \\
0 \\
1.99 \\
1.02 \\
2.38 \\
94.31\end{array}$ & $\begin{array}{c}75.65 \\
0.37 \\
14.34 \\
2.83 \\
0 \\
0.31 \\
2.9 \\
0.82 \\
2.77 \\
95.07\end{array}$ & $\begin{array}{r}78.32 \\
0.47 \\
12.41 \\
2.39 \\
0 \\
0.18 \\
2.3 \\
1.14 \\
2.79 \\
96.25\end{array}$ & $\begin{array}{r}79.29 \\
0.38 \\
12.23 \\
2.43 \\
0 \\
0 \\
2.04 \\
1.02 \\
2.61 \\
94.74\end{array}$ & $\begin{array}{r}72.43 \\
0.45 \\
14.11 \\
3.66 \\
0 \\
0.38 \\
2.77 \\
2.37 \\
3.82 \\
96.11\end{array}$ & $\begin{array}{r}72.88 \\
0.42 \\
14.09 \\
3.43 \\
0 \\
0.19 \\
2.68 \\
2.31 \\
3.99 \\
95.66\end{array}$ & $\begin{array}{r}73.12 \\
0.46 \\
14.21 \\
3.38 \\
0 \\
0.22 \\
2.56 \\
2.31 \\
3.73 \\
94.75\end{array}$ & $\begin{array}{c}72.56 \\
0.52 \\
14.02 \\
3.71 \\
0 \\
0.22 \\
2.93 \\
2.43 \\
3.62 \\
94.3\end{array}$ & $\begin{array}{r}72.65 \\
0.45 \\
14.12 \\
3.69 \\
0 \\
0.25 \\
2.76 \\
2.26 \\
3.81 \\
96.49\end{array}$ & $\begin{array}{c}71.84 \\
0.37 \\
15.91 \\
3.24 \\
0 \\
0 \\
2.58 \\
2.21 \\
3.85 \\
94.18\end{array}$ & $\begin{array}{r}78.85 \\
0.44 \\
12.29 \\
2.19 \\
0 \\
0.18 \\
1.98 \\
1.63 \\
2.44 \\
97.55\end{array}$ & $\begin{array}{c}79.19 \\
0.49 \\
12.06 \\
2.23 \\
0 \\
0 \\
2.2 \\
1.62 \\
2.2 \\
97.35\end{array}$ & $\begin{array}{c}79.71 \\
0.37 \\
12.22 \\
2.18 \\
0 \\
0 \\
2.07 \\
1.49 \\
1.96 \\
96.21\end{array}$ & $\begin{array}{c}79.42 \\
0.43 \\
12.1 \\
2.16 \\
0 \\
0 \\
2.13 \\
1.56 \\
2.21 \\
96.88\end{array}$ \\
\hline $\begin{array}{l}\text { Hole: } \\
\text { UNE number: } \\
\text { Core, section: } \\
\text { Interval }(\mathrm{cm}) \text { : }\end{array}$ & $\begin{array}{c}881 \mathrm{~B} \\
31 \\
12 \mathrm{H}-1 \\
140-141 \\
\end{array}$ & $\begin{array}{c}881 \mathrm{~B} \\
32 \\
12 \mathrm{H}-2 \\
19-20 \\
\end{array}$ & $\begin{array}{c}881 \mathrm{~B} \\
32 \\
12 \mathrm{H}-2 \\
19-20 \\
\end{array}$ & $\begin{array}{c}881 \mathrm{~B} \\
32 \\
12 \mathrm{H}-2 \\
19-20 \\
\end{array}$ & $\begin{array}{c}881 \mathrm{~B} \\
32 \\
12 \mathrm{H}-2 \\
19-20 \\
\end{array}$ & $\begin{array}{c}881 \mathrm{~B} \\
33 \\
13 \mathrm{H}-2 \\
118-119 \\
\end{array}$ & $\begin{array}{c}881 \mathrm{~B} \\
33 \\
13 \mathrm{H}-2 \\
118-119 \\
\end{array}$ & $\begin{array}{c}881 \mathrm{~B} \\
33 \\
13 \mathrm{H}-2 \\
118-119 \\
\end{array}$ & $\begin{array}{c}881 \mathrm{~B} \\
33 \\
13 \mathrm{H}-2 \\
118-119 \\
\end{array}$ & $\begin{array}{c}881 \mathrm{~B} \\
33 \\
13 \mathrm{H}-2 \\
118-119 \\
\end{array}$ & $\begin{array}{c}881 \mathrm{~B} \\
34 \\
13 \mathrm{H}-5 \\
42-43 \\
\end{array}$ & $\begin{array}{c}881 \mathrm{~B} \\
34 \\
13 \mathrm{H}-5 \\
42-43 \\
\end{array}$ & $\begin{array}{c}881 \mathrm{~B} \\
34 \\
13 \mathrm{H}-5 \\
42-43 \\
\end{array}$ & $\begin{array}{c}881 \mathrm{~B} \\
34 \\
13 \mathrm{H}-5 \\
42-43 \\
\end{array}$ & $\begin{array}{c}881 \mathrm{~B} \\
34 \\
13 \mathrm{H}-5 \\
42-43 \\
\end{array}$ \\
\hline $\begin{array}{l}\mathrm{SiO}_{2} \\
\mathrm{TiO}_{2} \\
\mathrm{Al}_{2} \mathrm{O}_{3} \\
\mathrm{FeO}^{*} \\
\mathrm{MnO} \\
\mathrm{MgO} \\
\mathrm{CaO} \\
\mathrm{K}_{2} \mathrm{O} \\
\mathrm{Na}_{2} \mathrm{O} \\
\text { Total }\end{array}$ & $\begin{array}{c}79.67 \\
0.27 \\
12.49 \\
2 \\
0 \\
0 \\
1.98 \\
1.51 \\
2.07 \\
97.38\end{array}$ & $\begin{array}{c}80.2 \\
0 \\
12.36 \\
0.99 \\
0 \\
0 \\
0.95 \\
2.47 \\
3.04 \\
95.99\end{array}$ & $\begin{array}{c}79.8 \\
0 \\
12.41 \\
0.89 \\
0 \\
0 \\
0.94 \\
2.48 \\
3.49 \\
97.1\end{array}$ & $\begin{array}{c}80.11 \\
0 \\
12.26 \\
1.05 \\
0 \\
0 \\
0.93 \\
2.31 \\
3.35 \\
95.37\end{array}$ & $\begin{array}{c}79.97 \\
0 \\
12.52 \\
0.93 \\
0 \\
0 \\
0.97 \\
2.53 \\
3.07 \\
96.38\end{array}$ & $\begin{array}{r}60.63 \\
1.42 \\
16.44 \\
7.63 \\
0 \\
2.18 \\
6.59 \\
1.43 \\
3.67 \\
97.67\end{array}$ & $\begin{array}{c}78.22 \\
0.23 \\
12.9 \\
1.71 \\
0 \\
0 \\
1.09 \\
2.77 \\
3.07 \\
94.67\end{array}$ & $\begin{array}{c}71.03 \\
0.78 \\
15.6 \\
4.37 \\
0 \\
0.47 \\
2.91 \\
1.98 \\
2.87 \\
95.41\end{array}$ & $\begin{array}{r}64.04 \\
0.89 \\
16.19 \\
5.66 \\
0.15 \\
1.11 \\
6.02 \\
1.68 \\
4.25 \\
98.52\end{array}$ & $\begin{array}{c}74.21 \\
0.5 \\
13.12 \\
3.2 \\
0 \\
0 \\
1.35 \\
3.94 \\
3.67 \\
97.23\end{array}$ & $\begin{array}{c}78.58 \\
0.4 \\
12.09 \\
2.23 \\
0 \\
0 \\
2.16 \\
1.64 \\
2.92 \\
94.64\end{array}$ & $\begin{array}{c}78.42 \\
0.4 \\
12.07 \\
2.25 \\
0 \\
0 \\
2.13 \\
1.76 \\
2.96 \\
96.05\end{array}$ & $\begin{array}{r}79.62 \\
0.51 \\
12.36 \\
2.04 \\
0 \\
0.22 \\
2.18 \\
1.61 \\
1.47 \\
95.62\end{array}$ & $\begin{array}{c}79.07 \\
0.44 \\
12.02 \\
2.05 \\
0 \\
0 \\
1.96 \\
1.71 \\
2.76 \\
95.46\end{array}$ & $\begin{array}{r}78.39 \\
0.38 \\
12.17 \\
2.24 \\
0 \\
0.15 \\
2.07 \\
1.72 \\
2.88 \\
95.94\end{array}$ \\
\hline $\begin{array}{l}\text { Hole: } \\
\text { UNE number: } \\
\text { Core, section: } \\
\text { Interval }(\mathrm{cm}) \text { : }\end{array}$ & $\begin{array}{c}881 \mathrm{~B} \\
34 \\
13 \mathrm{H}-5 \\
42-43 \\
\end{array}$ & $\begin{array}{c}881 \mathrm{~B} \\
34 \\
13 \mathrm{H}-5 \\
42-43 \\
\end{array}$ & $\begin{array}{c}881 \mathrm{~B} \\
34 \\
13 \mathrm{H}-5 \\
42-43 \\
\end{array}$ & $\begin{array}{c}881 \mathrm{~B} \\
34 \\
13 \mathrm{H}-5 \\
42-43 \\
\end{array}$ & $\begin{array}{c}881 \mathrm{~B} \\
36 \\
14 \mathrm{H}-5 \\
44-45 \\
\end{array}$ & $\begin{array}{c}881 \mathrm{~B} \\
36 \\
14 \mathrm{H}-5 \\
44-45 \\
\end{array}$ & $\begin{array}{c}881 \mathrm{~B} \\
38 \\
15 \mathrm{H}-4 \\
129-130 \\
\end{array}$ & $\begin{array}{c}881 \mathrm{~B} \\
38 \\
15 \mathrm{H}-4 \\
129-130 \\
\end{array}$ & $\begin{array}{c}881 \mathrm{~B} \\
39 \\
15 \mathrm{H}-6 \\
73-74 \\
\end{array}$ & $\begin{array}{c}881 \mathrm{~B} \\
39 \\
15 \mathrm{H}-6 \\
73-74 \\
\end{array}$ & $\begin{array}{c}881 \mathrm{~B} \\
39 \\
15 \mathrm{H}-6 \\
73-74 \\
\end{array}$ & $\begin{array}{c}881 \mathrm{~B} \\
39 \\
15 \mathrm{H}-6 \\
73-74 \\
\end{array}$ & $\begin{array}{c}881 \mathrm{~B} \\
39 \\
15 \mathrm{H}-6 \\
73-74 \\
\end{array}$ & $\begin{array}{c}881 \mathrm{~B} \\
41 \\
16 \mathrm{H}-1 \\
84-85 \\
\end{array}$ & $\begin{array}{c}881 \mathrm{~B} \\
41 \\
16 \mathrm{H}-1 \\
84-85 \\
\end{array}$ \\
\hline $\begin{array}{l}\mathrm{SiO}_{2} \\
\mathrm{TiO}_{2} \\
\mathrm{Al}_{2} \mathrm{O}_{3} \\
\mathrm{FeO}^{3} \\
\mathrm{MnO} \\
\mathrm{MgO} \\
\mathrm{CaO} \\
\mathrm{K}_{2} \mathrm{O} \\
\mathrm{Na}_{2} \mathrm{O} \\
\mathrm{Total}\end{array}$ & $\begin{array}{r}79.56 \\
0.23 \\
11.91 \\
2.21 \\
0 \\
0 \\
1.81 \\
1.54 \\
2.75 \\
95.29\end{array}$ & $\begin{array}{c}78.77 \\
0.39 \\
12.21 \\
2.14 \\
0 \\
0 \\
1.92 \\
1.75 \\
2.81 \\
96.55\end{array}$ & $\begin{array}{c}78.65 \\
0.45 \\
12.13 \\
2.28 \\
0 \\
0 \\
1.98 \\
1.64 \\
2.88 \\
96.71\end{array}$ & $\begin{array}{r}78.41 \\
0.41 \\
12.08 \\
2.14 \\
0 \\
0.17 \\
1.99 \\
1.67 \\
3.14 \\
96.79\end{array}$ & $\begin{array}{c}72.95 \\
0.7 \\
15.01 \\
3.57 \\
0 \\
0.36 \\
3.44 \\
1.6 \\
2.38 \\
91.53\end{array}$ & $\begin{array}{c}76.08 \\
0.9 \\
12.45 \\
3.49 \\
0 \\
0 \\
2.08 \\
2.48 \\
2.53 \\
92.1\end{array}$ & $\begin{array}{c}75.56 \\
0.34 \\
13.64 \\
3.17 \\
0 \\
0 \\
2.68 \\
0.99 \\
3.62 \\
95.85\end{array}$ & $\begin{array}{l}80 \\
0 \\
12.51 \\
1.03 \\
0 \\
0 \\
0.95 \\
2.53 \\
2.98 \\
94.52\end{array}$ & $\begin{array}{c}71.94 \\
0.5 \\
14.31 \\
3.45 \\
0 \\
0.32 \\
2.83 \\
2.4 \\
4.25 \\
98.82\end{array}$ & $\begin{array}{r}72.98 \\
0.35 \\
14.02 \\
3.24 \\
0 \\
0.24 \\
2.53 \\
2.37 \\
4.27 \\
98.73\end{array}$ & $\begin{array}{c}72.8 \\
0.42 \\
13.51 \\
3.79 \\
0 \\
0.17 \\
2.64 \\
2.36 \\
4.31 \\
98.71\end{array}$ & $\begin{array}{r}72.58 \\
0.45 \\
14.19 \\
3.54 \\
0 \\
0.24 \\
2.39 \\
2.76 \\
3.86 \\
96.81\end{array}$ & $\begin{array}{c}73.12 \\
0.39 \\
14.58 \\
3.14 \\
0 \\
0 \\
2.62 \\
2.25 \\
3.9 \\
98.04\end{array}$ & $\begin{array}{c}67.01 \\
0 \\
20.4 \\
0.35 \\
0 \\
0 \\
4.63 \\
1.86 \\
5.75 \\
102.33\end{array}$ & $\begin{array}{c}61.89 \\
1.87 \\
10.96 \\
11.32 \\
0 \\
3.43 \\
5.7 \\
2.1 \\
2.74 \\
101.38\end{array}$ \\
\hline $\begin{array}{l}\text { Hole: } \\
\text { UNE number: } \\
\text { Core, section: } \\
\text { Interval }(\mathrm{cm}):\end{array}$ & $\begin{array}{c}881 \mathrm{~B} \\
43 \\
16 \mathrm{H}-6 \\
145-146\end{array}$ & $\begin{array}{c}881 \mathrm{~B} \\
43 \\
16 \mathrm{H}-6 \\
145-146 \\
\end{array}$ & $\begin{array}{c}881 \mathrm{~B} \\
43 \\
16 \mathrm{H}-6 \\
145-146 \\
\end{array}$ & $\begin{array}{c}881 \mathrm{~B} \\
43 \\
16 \mathrm{H}-6 \\
145-146\end{array}$ & $\begin{array}{c}881 \mathrm{~B} \\
43 \\
16 \mathrm{H}-6 \\
145-146\end{array}$ & $\begin{array}{c}881 \mathrm{~B} \\
43 \\
16 \mathrm{H}-6 \\
145-146\end{array}$ & $\begin{array}{c}881 \mathrm{~B} \\
44 \\
16 \mathrm{H}-7 \\
30-31\end{array}$ & $\begin{array}{c}881 \mathrm{~B} \\
44 \\
16 \mathrm{H}-7 \\
30-31 \\
\end{array}$ & $\begin{array}{c}881 \mathrm{~B} \\
44 \\
16 \mathrm{H}-7 \\
30-31\end{array}$ & $\begin{array}{l}881 \mathrm{~B} \\
44 \\
16 \mathrm{H}-7 \\
30-31\end{array}$ & $\begin{array}{c}881 \mathrm{~B} \\
44 \\
16 \mathrm{H}-7 \\
30-31\end{array}$ & $\begin{array}{c}881 \mathrm{~B} \\
44 \\
16 \mathrm{H}-7 \\
30-31\end{array}$ & $\begin{array}{c}881 \mathrm{BB} \\
44 \\
16 \mathrm{H}-7 \\
30-31\end{array}$ & $\begin{array}{c}881 \mathrm{~B} \\
44 \\
16 \mathrm{H}-7 \\
30-31 \\
\end{array}$ & $\begin{array}{c}881 \mathrm{~B} \\
44 \\
16 \mathrm{H}-7 \\
30-31\end{array}$ \\
\hline $\begin{array}{l}\mathrm{SiO}_{2} \\
\mathrm{TiO}_{2} \\
\mathrm{Al}_{2} \mathrm{O}_{3} \\
\mathrm{FOO}^{*} \\
\mathrm{MnO} \\
\mathrm{MgO} \\
\mathrm{CaO} \\
\mathrm{K}_{2} \mathrm{O} \\
\mathrm{Na}_{2} \mathrm{O} \\
\text { Total }\end{array}$ & $\begin{array}{c}79.99 \\
0 \\
12.44 \\
0.96 \\
0 \\
0 \\
0.94 \\
3.73 \\
1.94 \\
93.25\end{array}$ & $\begin{array}{c}79.6 \\
0 \\
12.68 \\
1.31 \\
0 \\
0 \\
1.26 \\
2.68 \\
2.47 \\
94.73\end{array}$ & $\begin{array}{c}79.18 \\
0 \\
12.83 \\
1.41 \\
0 \\
0 \\
1.47 \\
2.54 \\
2.58 \\
95.36\end{array}$ & $\begin{array}{c}79.19 \\
0 \\
12.9 \\
1.42 \\
0 \\
0 \\
1.52 \\
2.57 \\
2.4 \\
94.37\end{array}$ & $\begin{array}{c}79.14 \\
0.17 \\
12.86 \\
1.46 \\
0 \\
0 \\
1.5 \\
2.53 \\
2.35 \\
94.82\end{array}$ & $\begin{array}{c}78.96 \\
0.18 \\
12.61 \\
1.47 \\
0 \\
0 \\
1.49 \\
2.55 \\
2.74 \\
95.93\end{array}$ & $\begin{array}{r}74 \\
0.37 \\
14.13 \\
3.05 \\
0.48 \\
0.34 \\
2.72 \\
1.43 \\
3.46 \\
95.83\end{array}$ & $\begin{array}{c}75.2 \\
0.31 \\
14.16 \\
1.55 \\
0.4 \\
0 \\
1.36 \\
3.27 \\
3.74 \\
95.56\end{array}$ & $\begin{array}{r}74.74 \\
0.47 \\
13.72 \\
3.06 \\
0.31 \\
0.19 \\
2.67 \\
1.48 \\
3.35 \\
95.12\end{array}$ & $\begin{array}{r}55.25 \\
0.96 \\
15.15 \\
12.64 \\
0.29 \\
4.44 \\
7.41 \\
1.33 \\
2.53 \\
97.35\end{array}$ & $\begin{array}{c}77.18 \\
0.16 \\
1.46 \\
1.41 \\
0 \\
0 \\
1.02 \\
3.22 \\
3.55 \\
94.28\end{array}$ & $\begin{array}{c}68.56 \\
1.36 \\
13.7 \\
6.72 \\
0.34 \\
0.61 \\
3.45 \\
2.12 \\
3.14 \\
94.99\end{array}$ & $\begin{array}{r}74.43 \\
0.35 \\
13.91 \\
2.99 \\
0.28 \\
0.22 \\
2.8 \\
1.51 \\
3.52 \\
95.78\end{array}$ & $\begin{array}{r}74.7 \\
0.39 \\
13.99 \\
2.98 \\
0.28 \\
0.32 \\
2.86 \\
1.46 \\
3.01 \\
95.14\end{array}$ & $\begin{array}{c}75.8 \\
0.15 \\
13.81 \\
1.53 \\
0.66 \\
0 \\
1.29 \\
3.07 \\
3.68 \\
95.22\end{array}$ \\
\hline
\end{tabular}


Table 5 (continued).

\begin{tabular}{|c|c|c|c|c|c|c|c|c|c|c|c|c|}
\hline $\begin{array}{l}\text { Hole: } \\
\text { UNE number: } \\
\text { Core, section: } \\
\text { Interval (cm): }\end{array}$ & $\begin{array}{c}881 \mathrm{~B} \\
45 \\
17 \mathrm{H}-1 \\
11-12\end{array}$ & $\begin{array}{c}881 \mathrm{~B} \\
45 \\
17 \mathrm{H}-1 \\
11-12\end{array}$ & $\begin{array}{c}881 \mathrm{~B} \\
45 \\
17 \mathrm{H}-1 \\
11-12\end{array}$ & $\begin{array}{c}881 \mathrm{~B} \\
46 \\
17 \mathrm{H}-1 \\
22-23\end{array}$ & $\begin{array}{c}881 \mathrm{~B} \\
46 \\
17 \mathrm{H}-1 \\
22-23\end{array}$ & $\begin{array}{l}881 \mathrm{~B} \\
46 \\
17 \mathrm{H}-1 \\
22-23\end{array}$ & $\begin{array}{c}881 \mathrm{~B} \\
46 \\
17 \mathrm{H}-1 \\
22-23\end{array}$ & $\begin{array}{c}881 \mathrm{~B} \\
47 \\
18 \mathrm{H}-1 \\
148-149\end{array}$ & $\begin{array}{c}881 \mathrm{~B} \\
47 \\
18 \mathrm{H}-1 \\
148-149\end{array}$ & $\begin{array}{c}881 \mathrm{~B} \\
47 \\
18 \mathrm{H}-1 \\
148-149\end{array}$ & $\begin{array}{c}881 \mathrm{C} \\
50 \\
21 \mathrm{X}-6 \\
40-41\end{array}$ & $\begin{array}{c}881 \mathrm{C} \\
50 \\
21 \mathrm{X}-6 \\
40-41\end{array}$ \\
\hline $\begin{array}{l}\mathrm{SiO}_{2} \\
\mathrm{TiO}_{2} \\
\mathrm{Al}_{2} \mathrm{O}_{3} \\
\mathrm{FeO}^{*} \\
\mathrm{MnO} \\
\mathrm{MgO} \\
\mathrm{CaO} \\
\mathrm{K}_{2} \mathrm{O} \\
\mathrm{Na}_{2} \mathrm{O} \\
\text { Total }\end{array}$ & $\begin{array}{c}59.12 \\
0.89 \\
15.69 \\
10.59 \\
0 \\
2.64 \\
7 \\
0.99 \\
3.09 \\
99.07\end{array}$ & $\begin{array}{c}66.21 \\
1.57 \\
14.17 \\
8.85 \\
0 \\
1 \\
4.51 \\
1.65 \\
2.04 \\
93.97\end{array}$ & $\begin{array}{l}65.56 \\
1.21 \\
17.44 \\
4.39 \\
0 \\
0 \\
5.2 \\
1.76 \\
4.44 \\
98.05\end{array}$ & $\begin{array}{r}69.83 \\
0.62 \\
14.38 \\
5.04 \\
0 \\
0.66 \\
3.76 \\
2.58 \\
3.12 \\
96.67\end{array}$ & $\begin{array}{r}71.24 \\
0.65 \\
14.17 \\
4.64 \\
0 \\
0.36 \\
3.18 \\
2.73 \\
3.03 \\
97.82\end{array}$ & $\begin{array}{r}69.15 \\
0.71 \\
14.63 \\
5.32 \\
0 \\
0.87 \\
4.07 \\
2.47 \\
2.77 \\
97.94\end{array}$ & $\begin{array}{r}67.63 \\
0.81 \\
14.83 \\
5.76 \\
0 \\
1.12 \\
4.28 \\
2.38 \\
3.19 \\
99.88\end{array}$ & $\begin{array}{r}62.95 \\
1.08 \\
15.38 \\
7.25 \\
0 \\
1.75 \\
6 \\
1.95 \\
3.63 \\
101.79\end{array}$ & $\begin{array}{r}67.13 \\
0.82 \\
14.74 \\
5.48 \\
0 \\
0.94 \\
4.19 \\
2.53 \\
4.17 \\
99.97\end{array}$ & $\begin{array}{r}65.85 \\
0.94 \\
15.06 \\
6.04 \\
0 \\
1.23 \\
4.71 \\
2.29 \\
3.87 \\
101.76\end{array}$ & $\begin{array}{c}80.56 \\
0.16 \\
11.76 \\
1.19 \\
0 \\
0 \\
0.97 \\
3.11 \\
2.25 \\
97.85\end{array}$ & $\begin{array}{c}80.32 \\
0 \\
11.88 \\
1.58 \\
0 \\
0 \\
1.39 \\
2.64 \\
2.19 \\
97.23\end{array}$ \\
\hline $\begin{array}{l}\text { Hole: } \\
\text { UNE number: } \\
\text { Core, section: } \\
\text { Interval }(\mathrm{cm}) \text { : }\end{array}$ & $\begin{array}{c}881 \mathrm{C} \\
50 \\
21 \mathrm{X}-6 \\
40-41 \\
\end{array}$ & $\begin{array}{c}881 \mathrm{C} \\
50 \\
21 \mathrm{X}-6 \\
40-41 \\
\end{array}$ & $\begin{array}{c}881 \mathrm{C} \\
50 \\
21 \mathrm{X}-6 \\
40-41 \\
\end{array}$ & $\begin{array}{c}881 \mathrm{C} \\
50 \\
21 \mathrm{X}-6 \\
40-41 \\
\end{array}$ & $\begin{array}{c}881 \mathrm{C} \\
50 \\
21 \mathrm{X}-6 \\
40-41 \\
\end{array}$ & $\begin{array}{c}881 \mathrm{C} \\
51 \\
23 \mathrm{X}-7 \\
26-27 \\
\end{array}$ & $\begin{array}{c}881 \mathrm{C} \\
51 \\
23 \mathrm{X}-7 \\
26-27 \\
\end{array}$ & $\begin{array}{c}881 \mathrm{C} \\
51 \\
23 \mathrm{X}-7 \\
26-27 \\
\end{array}$ & $\begin{array}{c}881 \mathrm{C} \\
51 \\
23 \mathrm{X}-7 \\
26-27 \\
\end{array}$ & $\begin{array}{c}881 C \\
51 \\
23 X-7 \\
26-27 \\
\end{array}$ & $\begin{array}{c}881 \mathrm{C} \\
51 \\
23 \mathrm{X}-7 \\
26-27 \\
\end{array}$ & $\begin{array}{c}881 \mathrm{C} \\
51 \\
23 \mathrm{X}-7 \\
26-27 \\
\end{array}$ \\
\hline $\begin{array}{l}\mathrm{SiO}_{2} \\
\mathrm{TiO}_{2} \\
\mathrm{Al}_{2} \mathrm{O}_{3} \\
\mathrm{FeO}^{*} \\
\mathrm{MnO} \\
\mathrm{MgO} \\
\mathrm{CaO} \\
\mathrm{K}_{2} \mathrm{O} \\
\mathrm{Na}_{2} \mathrm{O} \\
\text { Total }\end{array}$ & $\begin{array}{c}80.18 \\
0.13 \\
11.81 \\
1.31 \\
0 \\
0 \\
1.18 \\
2.82 \\
2.58 \\
98.62\end{array}$ & $\begin{array}{c}80.43 \\
0 \\
11.79 \\
1.2 \\
0 \\
0 \\
1 \\
3.15 \\
2.43 \\
97.27\end{array}$ & $\begin{array}{c}80.03 \\
0.14 \\
11.75 \\
1.41 \\
0 \\
0 \\
1.46 \\
2.71 \\
2.5 \\
98.51\end{array}$ & $\begin{array}{c}79.81 \\
0.25 \\
11.85 \\
1.54 \\
0 \\
0 \\
1.41 \\
2.62 \\
2.51 \\
98.6\end{array}$ & $\begin{array}{c}79.62 \\
0 \\
12.57 \\
0.59 \\
0 \\
0 \\
0.14 \\
4.77 \\
2.31 \\
98.01\end{array}$ & $\begin{array}{c}78.39 \\
0 \\
12.56 \\
0.3 \\
0 \\
0 \\
0.49 \\
4.81 \\
3.44 \\
96.85\end{array}$ & $\begin{array}{c}78.14 \\
0 \\
12.51 \\
0.45 \\
0 \\
0 \\
0.46 \\
5.41 \\
3.03 \\
95.99\end{array}$ & $\begin{array}{c}78.25 \\
0 \\
12.54 \\
0.35 \\
0 \\
0 \\
0.5 \\
5.35 \\
3.01 \\
97.43\end{array}$ & $\begin{array}{c}78.08 \\
0 \\
12.69 \\
0.42 \\
0 \\
0 \\
0.58 \\
5.14 \\
3.09 \\
98.03\end{array}$ & $\begin{array}{l}78.14 \\
0 \\
12.46 \\
0.41 \\
0 \\
0 \\
0.54 \\
4.93 \\
3.53 \\
97.2\end{array}$ & $\begin{array}{c}78.99 \\
0 \\
11.89 \\
1.5 \\
0 \\
0 \\
1.33 \\
2.22 \\
4.07 \\
96.7\end{array}$ & $\begin{array}{c}78.01 \\
0 \\
12.85 \\
0.28 \\
0 \\
0 \\
0.49 \\
4.66 \\
3.7 \\
97.7\end{array}$ \\
\hline
\end{tabular}

Notes: Major elements reported as wt\% oxides. UNE number refers to the ash layer number analyzed at UNE (see Table 1). Total = the original analytical total. Individual oxide values sum to $100 \%$. Zero values indicate that the element abundances are less than the detection limit of EDS. All Fe reported as FeO*. 
Table 6. Representative analyses of vitric shards from Hole 882A.

\begin{tabular}{|c|c|c|c|c|c|c|c|c|c|c|c|c|c|c|c|c|}
\hline $\begin{array}{l}\text { UNE number: } \\
\text { Core, section: } \\
\text { Interval }(\mathrm{cm}) \text { : }\end{array}$ & $\begin{array}{c}53 \\
1 H-4 \\
145-146 \\
\end{array}$ & $\begin{array}{c}53 \\
1 \mathrm{H}-4 \\
145-146 \\
\end{array}$ & $\begin{array}{c}53 \\
1 \mathrm{H}-4 \\
145-146 \\
\end{array}$ & $\begin{array}{c}53 \\
1 \mathrm{H}-4 \\
145-146 \\
\end{array}$ & $\begin{array}{c}53 \\
1 \mathrm{H}-4 \\
145-146 \\
\end{array}$ & $\begin{array}{c}54 \\
1 \mathrm{H}-6 \\
83-84 \\
\end{array}$ & $\begin{array}{c}54 \\
1 \mathrm{H}-6 \\
83-84 \\
\end{array}$ & $\begin{array}{c}54 \\
1 \mathrm{H}-6 \\
83-84 \\
\end{array}$ & $\begin{array}{c}54 \\
1 \mathrm{H}-6 \\
83-84 \\
\end{array}$ & $\begin{array}{c}54 \\
1 \mathrm{H}-6 \\
83-84 \\
\end{array}$ & $\begin{array}{c}54 \\
1 \mathrm{H}-6 \\
83-84 \\
\end{array}$ & $\begin{array}{c}55 \\
2 \mathrm{H}-5 \\
2 \mathrm{1}-22 \\
\end{array}$ & $\begin{array}{c}55 \\
2 \mathrm{H}-5 \\
21-22 \\
\end{array}$ & $\begin{array}{c}55 \\
2 \mathrm{H}-5 \\
21-22 \\
\end{array}$ & $\begin{array}{r}55 \\
2 \mathrm{H}-5 \\
21-22 \\
\end{array}$ & $\begin{array}{c}55 \\
2 \mathrm{H}-5 \\
21-22 \\
\end{array}$ \\
\hline $\begin{array}{l}\mathrm{SiO}_{2} \\
\mathrm{TiO}_{2} \\
\mathrm{Al}_{2} \mathrm{O}_{3} \\
\mathrm{FeO} \\
\mathrm{MnO} \\
\mathrm{MgO} \\
\mathrm{CaO} \\
\mathrm{K}_{2} \mathrm{O} \\
\mathrm{Na}_{2} \mathrm{O} \\
\mathrm{Total}^{2}\end{array}$ & $\begin{array}{c}77.02 \\
0.28 \\
13.44 \\
2.01 \\
0 \\
0 \\
1.43 \\
2.86 \\
2.96 \\
97.32\end{array}$ & $\begin{array}{l}76.8 \\
0.3 \\
13.71 \\
1.96 \\
0 \\
0 \\
1.43 \\
2.86 \\
2.95 \\
98.14\end{array}$ & $\begin{array}{l}77.1 \\
0.22 \\
13.42 \\
1.98 \\
0 \\
0 \\
1.48 \\
2.86 \\
2.94 \\
98.61\end{array}$ & $\begin{array}{c}77.43 \\
0.31 \\
13.49 \\
1.88 \\
0 \\
0 \\
1.38 \\
2.82 \\
2.69 \\
97.8\end{array}$ & $\begin{array}{c}77.53 \\
0.31 \\
13.59 \\
1.66 \\
0 \\
0 \\
1.07 \\
2.98 \\
2.86 \\
98.08\end{array}$ & $\begin{array}{r}68.02 \\
0.85 \\
16.28 \\
4.14 \\
0 \\
1.01 \\
3.11 \\
2.66 \\
3.94 \\
97.26\end{array}$ & $\begin{array}{c}73.59 \\
0.53 \\
14.96 \\
2.14 \\
0 \\
0 \\
1.39 \\
3.49 \\
3.91 \\
92.18\end{array}$ & $\begin{array}{c}73.75 \\
0.41 \\
14.92 \\
1.99 \\
0 \\
0 \\
1.24 \\
3.54 \\
4.14 \\
98.12\end{array}$ & $\begin{array}{c}72.99 \\
0.51 \\
14.92 \\
2.08 \\
0 \\
0.14 \\
1.32 \\
3.6 \\
4.43 \\
96.87\end{array}$ & $\begin{array}{c}56.51 \\
3.41 \\
18.5 \\
8.03 \\
0 \\
1.97 \\
5.77 \\
1.01 \\
4.8 \\
97.19\end{array}$ & $\begin{array}{c}73.27 \\
0.34 \\
15.1 \\
2.02 \\
0 \\
0 \\
1.24 \\
3.41 \\
4.63 \\
96.14\end{array}$ & $\begin{array}{c}71.17 \\
0.37 \\
16.44 \\
1.98 \\
0 \\
0 \\
2.45 \\
3.08 \\
4.51 \\
97.73\end{array}$ & $\begin{array}{c}72 \\
0.53 \\
15.18 \\
2.43 \\
0 \\
0.35 \\
1.65 \\
3.65 \\
4.2 \\
96.66\end{array}$ & $\begin{array}{c}70.77 \\
0.77 \\
15.54 \\
2.71 \\
0 \\
0.4 \\
1.9 \\
3.34 \\
4.56 \\
99.02\end{array}$ & $\begin{array}{c}71.52 \\
0.6 \\
15.44 \\
2.48 \\
0 \\
0.34 \\
1.82 \\
3.46 \\
4.35 \\
97.65\end{array}$ & $\begin{array}{r}71.48 \\
0.64 \\
15.37 \\
2.54 \\
0 \\
0.43 \\
1.85 \\
3.48 \\
4.21 \\
97.33\end{array}$ \\
\hline & & & & & & & & & & & & & & & & \\
\hline $\begin{array}{l}\text { UNE number: } \\
\text { Core, section: } \\
\text { Interval }(\mathrm{cm}) \text { : }\end{array}$ & $\begin{array}{c}55 \\
2 \mathrm{H}-5 \\
21-22 \\
\end{array}$ & $\begin{array}{c}56 \\
2 \mathrm{H}-6 \\
148-149 \\
\end{array}$ & $\begin{array}{c}57 \\
2 \mathrm{H}-7 \\
17-18 \\
\end{array}$ & $\begin{array}{c}57 \\
2 \mathrm{H}-7 \\
17-18\end{array}$ & $\begin{array}{c}57 \\
2 \mathrm{H}-7 \\
17-18 \\
\end{array}$ & $\begin{array}{c}57 \\
2 \mathrm{H}-7 \\
17-18 \\
\end{array}$ & $\begin{array}{c}57 \\
2 \mathrm{H}-7 \\
17-18 \\
\end{array}$ & $\begin{array}{c}58 \\
3 \mathrm{H}-4 \\
18-19 \\
\end{array}$ & $\begin{array}{c}58 \\
3 \mathrm{H}-4 \\
18-19 \\
\end{array}$ & $\begin{array}{c}58 \\
3 \mathrm{H}-4 \\
18-19 \\
\end{array}$ & $\begin{array}{c}58 \\
3 \mathrm{H}-4 \\
18-19 \\
\end{array}$ & $\begin{array}{c}58 \\
3 \mathrm{H}-4 \\
18-19 \\
\end{array}$ & $\begin{array}{c}58 \\
3 \mathrm{H}-4 \\
18-19 \\
\end{array}$ & $\begin{array}{c}59 \\
3 \mathrm{H}-4 \\
118-120 \\
\end{array}$ & $\begin{array}{c}59 \\
3 \mathrm{H}-4 \\
118-120 \\
\end{array}$ & $\begin{array}{c}59 \\
3 \mathrm{H}-4 \\
118-120 \\
\end{array}$ \\
\hline $\begin{array}{l}\mathrm{SiO}_{2} \\
\mathrm{TiO}_{2} \\
\mathrm{Al}_{2} \mathrm{O}_{3} \\
\mathrm{FeO}^{*} \\
\mathrm{MnO} \\
\mathrm{MgO} \\
\mathrm{CaO} \\
\mathrm{K}_{2} \mathrm{O} \\
\mathrm{Na}_{2} \mathrm{O} \\
\mathrm{Total}\end{array}$ & $\begin{array}{c}72.2 \\
0.56 \\
15.46 \\
2.24 \\
0 \\
0 \\
1.76 \\
3.48 \\
4.29 \\
97.27\end{array}$ & $\begin{array}{l}81.58 \\
0 \\
12.17 \\
1.03 \\
0 \\
0 \\
0.23 \\
2.87 \\
2.12 \\
97.65\end{array}$ & $\begin{array}{c}70.83 \\
0.64 \\
16.16 \\
3.25 \\
0 \\
0.4 \\
2.32 \\
3.33 \\
3.09 \\
97.92\end{array}$ & $\begin{array}{c}64.79 \\
1.33 \\
13.8 \\
7.88 \\
0 \\
2.69 \\
4.62 \\
2.47 \\
2.44 \\
97.95\end{array}$ & $\begin{array}{c}70.78 \\
0.77 \\
15.94 \\
3.1 \\
0 \\
0.38 \\
2.36 \\
3.4 \\
3.27 \\
99.26\end{array}$ & $\begin{array}{c}73.26 \\
0.58 \\
15.82 \\
2.5 \\
0 \\
0 \\
1.62 \\
3.61 \\
2.6 \\
97.18\end{array}$ & $\begin{array}{r}71.83 \\
0.68 \\
15.74 \\
2.71 \\
0 \\
0.36 \\
2.02 \\
3.45 \\
3.21 \\
98.75\end{array}$ & $\begin{array}{l}77.6 \\
0.21 \\
13.73 \\
1.73 \\
0 \\
0 \\
2.04 \\
1.61 \\
3.08 \\
97.5\end{array}$ & $\begin{array}{c}79.28 \\
0 \\
12.98 \\
1.49 \\
0 \\
0 \\
1.68 \\
1.78 \\
2.79 \\
97.88\end{array}$ & $\begin{array}{c}79.82 \\
0 \\
13.01 \\
1.45 \\
0 \\
0 \\
1.61 \\
1.74 \\
2.37 \\
96.07\end{array}$ & $\begin{array}{c}79.14 \\
0.19 \\
13.09 \\
1.47 \\
0 \\
0 \\
1.62 \\
1.81 \\
2.67 \\
98.31\end{array}$ & $\begin{array}{c}79.4 \\
0.17 \\
13.07 \\
1.43 \\
0 \\
0 \\
1.67 \\
1.76 \\
2.5 \\
97.02\end{array}$ & $\begin{array}{c}80.34 \\
0.21 \\
12.43 \\
1.35 \\
0 \\
0 \\
1.5 \\
1.71 \\
2.47 \\
97.5\end{array}$ & $\begin{array}{c}77.53 \\
0.2 \\
13.15 \\
2.93 \\
0 \\
0 \\
2.28 \\
1.78 \\
2.13 \\
96.98\end{array}$ & $\begin{array}{c}79.96 \\
0 \\
12.81 \\
0.34 \\
0 \\
0 \\
0.58 \\
3.77 \\
2.56 \\
98.82\end{array}$ & $\begin{array}{l}80.1 \\
0 \\
12.45 \\
0.38 \\
0 \\
0 \\
0.53 \\
3.92 \\
2.62 \\
98.25\end{array}$ \\
\hline $\begin{array}{l}\text { UNE number: } \\
\text { Core, section: } \\
\text { Interval }(\mathrm{cm}):\end{array}$ & $\begin{array}{c}60 \\
4 \mathrm{H}-5 \\
12-13 \\
\end{array}$ & $\begin{array}{c}60 \\
4 \mathrm{H}-5 \\
12-13 \\
\end{array}$ & $\begin{array}{c}60 \\
4 \mathrm{H}-5 \\
12-13 \\
\end{array}$ & $\begin{array}{c}60 \\
4 \mathrm{H}-5 \\
12-13 \\
\end{array}$ & $\begin{array}{c}60 \\
4 \mathrm{H}-5 \\
12-13 \\
\end{array}$ & $\begin{array}{c}61 \\
5 \mathrm{H}-4 \\
149-150 \\
\end{array}$ & $\begin{array}{c}61 \\
5 \mathrm{H}-4 \\
149-150 \\
\end{array}$ & $\begin{array}{c}61 \\
5 \mathrm{H}-4 \\
149-150\end{array}$ & $\begin{array}{c}62 \\
6 \mathrm{H}-1 \\
32-33 \\
\end{array}$ & $\begin{array}{c}62 \\
6 \mathrm{H}-1 \\
32-33 \\
\end{array}$ & $\begin{array}{c}62 \\
6 \mathrm{H}-1 \\
32-33 \\
\end{array}$ & $\begin{array}{c}62 \\
6 \mathrm{H}-1 \\
32-33 \\
\end{array}$ & $\begin{array}{c}62 \\
6 \mathrm{H}-1 \\
32-33 \\
\end{array}$ & $\begin{array}{c}63 \\
6 \mathrm{H}-4 \\
29-30 \\
\end{array}$ & $\begin{array}{c}63 \\
6 \mathrm{H}-4 \\
29-30 \\
\end{array}$ & $\begin{array}{c}63 \\
6 \mathrm{H}-4 \\
29-30 \\
\end{array}$ \\
\hline $\begin{array}{l}\mathrm{SiO}_{2} \\
\mathrm{TiO}_{2} \\
\mathrm{Al}_{2} \mathrm{O}_{3} \\
\mathrm{FeO} \\
\mathrm{MnO} \\
\mathrm{MgO} \\
\mathrm{CaO} \\
\mathrm{K}_{2} \mathrm{O} \\
\mathrm{Na}_{2} \mathrm{O} \\
\text { Total }\end{array}$ & $\begin{array}{c}73.72 \\
0.67 \\
14.36 \\
3.01 \\
0 \\
0 \\
1.78 \\
2.25 \\
4.26 \\
97.69\end{array}$ & $\begin{array}{r}73.36 \\
0.46 \\
14.34 \\
3.17 \\
0 \\
0.18 \\
2.01 \\
2.35 \\
4.14 \\
98.07\end{array}$ & $\begin{array}{c}73.26 \\
0.59 \\
14.08 \\
3.15 \\
0 \\
0.28 \\
1.9 \\
2.39 \\
4.34 \\
98.34\end{array}$ & $\begin{array}{c}73.85 \\
0.46 \\
14.18 \\
3.25 \\
0 \\
0 \\
1.83 \\
2.18 \\
4.24 \\
97.45\end{array}$ & $\begin{array}{r}73.86 \\
0.55 \\
14.04 \\
2.99 \\
0 \\
0 \\
1.76 \\
2.48 \\
4.31 \\
96.89\end{array}$ & $\begin{array}{c}74.03 \\
0.49 \\
14 \\
3.86 \\
0 \\
0.3 \\
2.79 \\
1.73 \\
2.8 \\
97.62\end{array}$ & $\begin{array}{c}73.59 \\
0.44 \\
13.94 \\
3.94 \\
0 \\
0.29 \\
3.13 \\
1.8 \\
2.87 \\
98\end{array}$ & $\begin{array}{c}70.09 \\
0.71 \\
14.83 \\
5.29 \\
0 \\
1.02 \\
4.03 \\
1.44 \\
2.6 \\
97.38\end{array}$ & $\begin{array}{r}75.01 \\
0.53 \\
13.97 \\
2.45 \\
0 \\
0.22 \\
2.04 \\
2.93 \\
2.87 \\
98.52\end{array}$ & $\begin{array}{c}75.24 \\
0.4 \\
14.37 \\
2.34 \\
0 \\
0 \\
2 \\
2.85 \\
2.8 \\
97.91\end{array}$ & $\begin{array}{r}75.06 \\
0.48 \\
13.98 \\
2.41 \\
0 \\
0.2 \\
2.05 \\
2.83 \\
2.98 \\
97.65\end{array}$ & $\begin{array}{c}77.75 \\
0.6 \\
12.51 \\
2.03 \\
0 \\
0 \\
1.09 \\
3.38 \\
2.63 \\
97.31\end{array}$ & $\begin{array}{r}74.53 \\
0.52 \\
14.15 \\
2.61 \\
0 \\
0.25 \\
2.34 \\
2.92 \\
2.68 \\
98.11\end{array}$ & $\begin{array}{c}73.63 \\
0.44 \\
14.06 \\
3.68 \\
0 \\
0 \\
1.79 \\
3.41 \\
2.98 \\
95.66\end{array}$ & $\begin{array}{c}74.24 \\
0.32 \\
14.03 \\
3.28 \\
0 \\
0 \\
1.96 \\
3.31 \\
2.86 \\
96.6\end{array}$ & $\begin{array}{r}74.27 \\
0.43 \\
14.12 \\
3.15 \\
0 \\
0 \\
1.86 \\
3.17 \\
3 \\
97.14\end{array}$ \\
\hline $\begin{array}{l}\text { UNE number: } \\
\text { Core, section: } \\
\text { Interval }(\mathrm{cm}) \text { : }\end{array}$ & $\begin{array}{c}63 \\
6 \mathrm{H}-4 \\
29-30 \\
\end{array}$ & $\begin{array}{c}63 \\
6 \mathrm{H}-4 \\
29-30 \\
\end{array}$ & $\begin{array}{c}63 \\
6 \mathrm{H}-4 \\
29-30 \\
\end{array}$ & $\begin{array}{c}63 \\
6 \mathrm{H}-4 \\
29-30 \\
\end{array}$ & $\begin{array}{c}64 \\
8 \mathrm{H}-2 \\
133-135 \\
\end{array}$ & $\begin{array}{c}64 \\
8 \mathrm{H}-2 \\
133-135 \\
\end{array}$ & $\begin{array}{c}64 \\
8 \mathrm{H}-2 \\
133-135 \\
\end{array}$ & $\begin{array}{c}64 \\
8 \mathrm{H}-2 \\
133-135 \\
\end{array}$ & $\begin{array}{c}64 \\
8 \mathrm{H}-2 \\
133-135 \\
\end{array}$ & $\begin{array}{c}65 \\
8 \mathrm{H}-3 \\
12-13 \\
\end{array}$ & $\begin{array}{c}65 \\
8 \mathrm{H}-3 \\
12 \sim 13 \\
\end{array}$ & $\begin{array}{c}65 \\
8 \mathrm{H}-3 \\
12 \sim 13 \\
\end{array}$ & $\begin{array}{c}65 \\
8 \mathrm{H}-3 \\
12 \sim 13 \\
\end{array}$ & $\begin{array}{c}65 \\
8 \mathrm{H}-3 \\
12-13 \\
\end{array}$ & $\begin{array}{c}65 \\
8 \mathrm{H}-3 \\
12-13 \\
\end{array}$ & $\begin{array}{c}65 \\
8 \mathrm{H}-3 \\
12 \sim 13 \\
\end{array}$ \\
\hline $\begin{array}{l}\mathrm{SiO}_{2} \\
\mathrm{TiO}_{2} \\
\mathrm{Al}_{2} \mathrm{O}_{3} \\
\mathrm{FeO} \\
\mathrm{MnO} \\
\mathrm{MgO} \\
\mathrm{CaO} \\
\mathrm{C}_{2} \mathrm{O} \\
\mathrm{Na}_{2} \mathrm{O} \\
\text { Total }\end{array}$ & $\begin{array}{r}73.83 \\
0.48 \\
14.02 \\
3.33 \\
0 \\
0 \\
1.9 \\
3.17 \\
3.27 \\
97.94\end{array}$ & $\begin{array}{l}74.2 \\
0.47 \\
14 \\
3.44 \\
0 \\
0 \\
1.86 \\
3.31 \\
2.72 \\
97.92\end{array}$ & $\begin{array}{c}74.82 \\
0.34 \\
14.08 \\
3.38 \\
0 \\
0 \\
1.73 \\
3.14 \\
2.51 \\
96.12\end{array}$ & $\begin{array}{r}74.43 \\
0.45 \\
13.91 \\
3.27 \\
0 \\
0 \\
1.9 \\
3.21 \\
2.85 \\
96.49\end{array}$ & $\begin{array}{c}73.54 \\
0.67 \\
14.2 \\
3.2 \\
0 \\
0.35 \\
2.87 \\
2.3 \\
2.88 \\
96.83\end{array}$ & $\begin{array}{c}73.58 \\
0.56 \\
14.24 \\
3.4 \\
0 \\
0.26 \\
3.1 \\
2.02 \\
2.84 \\
96.57\end{array}$ & $\begin{array}{c}73.71 \\
0.62 \\
13.93 \\
3.28 \\
0 \\
0.36 \\
3.02 \\
2.1 \\
2.97 \\
97.29\end{array}$ & $\begin{array}{r}73.31 \\
0.69 \\
14.35 \\
3.12 \\
0 \\
0.48 \\
3.07 \\
2.12 \\
2.85 \\
97.51\end{array}$ & $\begin{array}{c}73.63 \\
0.66 \\
14.3 \\
3.1 \\
0 \\
0.51 \\
2.75 \\
2.22 \\
2.83 \\
97.54\end{array}$ & $\begin{array}{c}76.17 \\
0.25 \\
14.14 \\
1.28 \\
0 \\
0 \\
1.18 \\
3.41 \\
3.57 \\
97.49\end{array}$ & $\begin{array}{c}79.37 \\
0 \\
12.12 \\
0.66 \\
0 \\
0 \\
0.37 \\
4.01 \\
3.48 \\
96.59\end{array}$ & $\begin{array}{c}79.03 \\
0 \\
12.41 \\
0.58 \\
0 \\
0 \\
0.47 \\
4.09 \\
3.42 \\
97.8\end{array}$ & $\begin{array}{c}78.48 \\
0.2 \\
12.5 \\
0.86 \\
0 \\
0 \\
0.45 \\
3.96 \\
3.56 \\
97.51\end{array}$ & $\begin{array}{c}79.19 \\
0.15 \\
12.29 \\
0.6 \\
0 \\
0 \\
0.4 \\
3.89 \\
3.48 \\
97.1\end{array}$ & $\begin{array}{c}76.09 \\
0.2 \\
13.99 \\
1.21 \\
0 \\
0 \\
1.27 \\
3.48 \\
3.75 \\
96.56\end{array}$ & $\begin{array}{c}75.04 \\
0.3 \\
14.16 \\
1.24 \\
0 \\
0.13 \\
1.29 \\
3.6 \\
4.23 \\
98.86\end{array}$ \\
\hline
\end{tabular}


Table 6 (continued).

\begin{tabular}{|c|c|c|c|c|c|c|c|c|c|c|c|c|c|c|c|c|}
\hline $\begin{array}{l}\text { UNE number: } \\
\text { Core, section: } \\
\text { Interval }(\mathrm{cm}) \text { : }\end{array}$ & $\begin{array}{c}65 \\
8 \mathrm{H}-3 \\
12 \sim 13 \\
\end{array}$ & $\begin{array}{c}67 \\
8 \mathrm{H}-6 \\
54-55 \\
\end{array}$ & $\begin{array}{c}68 \\
8 \mathrm{H}-7 \\
12 \sim 13\end{array}$ & $\begin{array}{c}68 \\
8 \mathrm{H}-7 \\
12 \sim 13 \\
\end{array}$ & $\begin{array}{c}68 \\
8 \mathrm{H}-7 \\
12-13 \\
\end{array}$ & $\begin{array}{c}69 \\
9 \mathrm{H}-2 \\
14-15 \\
\end{array}$ & $\begin{array}{c}70 \\
9 \mathrm{H}-3 \\
89-91 \\
\end{array}$ & $\begin{array}{c}70 \\
9 \mathrm{H}-3 \\
89-91 \\
\end{array}$ & $\begin{array}{c}71 \\
9 \mathrm{H}-5 \\
76-77 \\
\end{array}$ & $\begin{array}{c}71 \\
9 \mathrm{H}-5 \\
76-77 \\
\end{array}$ & $\begin{array}{c}71 \\
9 \mathrm{H}-5 \\
76-77 \\
\end{array}$ & $\begin{array}{c}71 \\
9 \mathrm{H}-5 \\
76-77 \\
\end{array}$ & $\begin{array}{c}73 \\
9 \mathrm{H}-6 \\
58-59 \\
\end{array}$ & $\begin{array}{c}73 \\
9 \mathrm{H}-6 \\
58-59\end{array}$ & $\begin{array}{c}73 \\
9 \mathrm{H}-6 \\
58-59\end{array}$ & $\begin{array}{c}73 \\
9 \mathrm{H}-6 \\
58-59 \\
\end{array}$ \\
\hline $\begin{array}{l}\mathrm{SiO}_{2} \\
\mathrm{TiO}_{2} \\
\mathrm{Al}_{2} \mathrm{O}_{3} \\
\mathrm{FeO}^{*} \\
\mathrm{MnO} \\
\mathrm{MgO} \\
\mathrm{CgO} \\
\mathrm{K}_{2} \mathrm{O} \\
\mathrm{Na}_{2} \mathrm{O} \\
\text { Total }\end{array}$ & $\begin{array}{c}78.89 \\
0 \\
12.47 \\
0.68 \\
0 \\
0 \\
0.38 \\
4.16 \\
3.41 \\
98.12\end{array}$ & $\begin{array}{c}76.26 \\
0.17 \\
13.71 \\
1.47 \\
0 \\
0 \\
1.84 \\
2.52 \\
4.04 \\
98.87\end{array}$ & $\begin{array}{r}74.26 \\
0.37 \\
13.35 \\
4.63 \\
0 \\
0.2 \\
3.02 \\
1.69 \\
2.48 \\
97.19\end{array}$ & $\begin{array}{r}74.66 \\
0.39 \\
13.15 \\
4.41 \\
0 \\
0.13 \\
2.79 \\
1.83 \\
2.65 \\
98.83\end{array}$ & $\begin{array}{r}75.12 \\
0.45 \\
13.16 \\
4.37 \\
0 \\
0.22 \\
2.73 \\
1.72 \\
2.23 \\
98.54\end{array}$ & $\begin{array}{r}72.49 \\
0.67 \\
14.28 \\
3.79 \\
0 \\
0.17 \\
1.93 \\
2.99 \\
3.67 \\
97.42\end{array}$ & $\begin{array}{r}72.42 \\
0.51 \\
14.75 \\
3.17 \\
0 \\
0.31 \\
2.36 \\
2.6 \\
3.89 \\
98.11\end{array}$ & $\begin{array}{r}70.36 \\
0.85 \\
14.65 \\
4.32 \\
0 \\
0.53 \\
2.67 \\
2.68 \\
3.94 \\
9.6\end{array}$ & $\begin{array}{c}76.16 \\
0.35 \\
14.22 \\
1.99 \\
0 \\
0 \\
1.56 \\
2.81 \\
2.9 \\
95.7\end{array}$ & $\begin{array}{c}75.9 \\
0.44 \\
14.3 \\
1.94 \\
0 \\
0 \\
1.54 \\
2.97 \\
2.9 \\
94.68\end{array}$ & $\begin{array}{r}76.28 \\
0.35 \\
14.06 \\
1.86 \\
0 \\
0 \\
1.49 \\
2.83 \\
3.13 \\
95.16\end{array}$ & $\begin{array}{c}76.68 \\
0.38 \\
13.59 \\
1.59 \\
0 \\
0 \\
1.18 \\
3.28 \\
3.3 \\
95.46\end{array}$ & $\begin{array}{c}71.6 \\
0.66 \\
15.07 \\
3.4 \\
0 \\
0.56 \\
2.69 \\
2.59 \\
3.43 \\
97.81\end{array}$ & $\begin{array}{c}74.3 \\
0.34 \\
14.91 \\
1.06 \\
0 \\
0 \\
1.43 \\
3.44 \\
4.53 \\
98.45\end{array}$ & $\begin{array}{r}73.55 \\
0.74 \\
14.57 \\
2.96 \\
0.12 \\
0.35 \\
2.09 \\
2.73 \\
2.89 \\
98.43\end{array}$ & $\begin{array}{c}71.31 \\
0.59 \\
15.25 \\
3.75 \\
0 \\
0.7 \\
2.96 \\
2.47 \\
2.98 \\
97.73\end{array}$ \\
\hline $\begin{array}{l}\text { UNE number: } \\
\text { Core, section: } \\
\text { Interval }(\mathrm{cm}) \text { : }\end{array}$ & $\begin{array}{c}74 \\
9 \mathrm{H}-6 \\
135-136 \\
\end{array}$ & $\begin{array}{c}76 \\
11 \mathrm{H}-1 \\
63-65\end{array}$ & $\begin{array}{c}76 \\
11 \mathrm{H}-1 \\
63-65\end{array}$ & $\begin{array}{c}76 \\
11 \mathrm{H}-1 \\
63-65\end{array}$ & $\begin{array}{c}77 \\
11 \mathrm{H}-4 \\
133-134 \\
\end{array}$ & $\begin{array}{c}77 \\
11 \mathrm{H}-4 \\
133-134 \\
\end{array}$ & $\begin{array}{c}77 \\
11 \mathrm{H}-4 \\
133-134 \\
\end{array}$ & $\begin{array}{c}77 \\
11 \mathrm{H}-4 \\
133-134 \\
\end{array}$ & $\begin{array}{c}77 \\
11 \mathrm{H}-4 \\
133-134 \\
\end{array}$ & $\begin{array}{c}78 \\
23 \mathrm{H}-6 \\
39-40 \\
\end{array}$ & $\begin{array}{c}79 \\
24 \mathrm{H}-1 \\
100-101 \\
\end{array}$ & $\begin{array}{c}80 \\
24 \mathrm{H}-4 \\
144-145 \\
\end{array}$ & $\begin{array}{c}80 \\
24 \mathrm{H}-4 \\
144-145\end{array}$ & $\begin{array}{c}80 \\
24 \mathrm{H}-4 \\
144-145\end{array}$ & $\begin{array}{c}80 \\
24 \mathrm{H}-4 \\
144-145\end{array}$ & $\begin{array}{c}80 \\
24 \mathrm{H}-4 \\
144-145\end{array}$ \\
\hline $\begin{array}{l}\mathrm{SiO}_{2} \\
\mathrm{TiO}_{2} \\
\mathrm{Al}_{2} \mathrm{O}_{3} \\
\mathrm{FeO}^{*} \\
\mathrm{MnO} \\
\mathrm{MgO} \\
\mathrm{CaO} \\
\mathrm{K}_{2} \mathrm{O} \\
\mathrm{Na}_{2} \mathrm{O} \\
\mathrm{Total}\end{array}$ & $\begin{array}{c}58.82 \\
1.24 \\
15.23 \\
11.47 \\
0.17 \\
2.12 \\
6.7 \\
1.4 \\
2.86 \\
98.84\end{array}$ & $\begin{array}{r}58.77 \\
1.25 \\
15.76 \\
9.37 \\
0 \\
2.8 \\
7.26 \\
1.34 \\
3.44 \\
101.88\end{array}$ & $\begin{array}{r}66.87 \\
1.13 \\
15.73 \\
6.16 \\
0 \\
0.86 \\
3.89 \\
2.43 \\
293 \\
99.54\end{array}$ & $\begin{array}{r}56.09 \\
1.27 \\
16.05 \\
11.07 \\
0 \\
3.19 \\
8.04 \\
1.07 \\
3.23 \\
103.36\end{array}$ & $\begin{array}{c}73.72 \\
0.43 \\
13.35 \\
4.02 \\
0 \\
0 \\
2.41 \\
1.97 \\
4.1 \\
100.76\end{array}$ & $\begin{array}{c}73.1 \\
0.57 \\
13.49 \\
4.28 \\
0 \\
0 \\
2.68 \\
1.95 \\
3.92 \\
100.72\end{array}$ & $\begin{array}{c}76.02 \\
0.36 \\
13.06 \\
3.59 \\
0 \\
0 \\
2.15 \\
2.07 \\
2.76 \\
98.65\end{array}$ & $\begin{array}{r}64.96 \\
0.77 \\
15.19 \\
7.31 \\
0 \\
1.75 \\
5.71 \\
1.22 \\
3.1 \\
101.08\end{array}$ & $\begin{array}{r}65.01 \\
0.77 \\
15.23 \\
7.36 \\
0.14 \\
1.65 \\
5.58 \\
1.29 \\
2.98 \\
101.2\end{array}$ & $\begin{array}{r}67.73 \\
2.39 \\
11.21 \\
10.06 \\
0 \\
0.32 \\
2.2 \\
2.56 \\
3.53 \\
99.67\end{array}$ & $\begin{array}{r}64.06 \\
1.25 \\
16.11 \\
7.38 \\
0 \\
1.53 \\
4.93 \\
1.67 \\
3.08 \\
98.5\end{array}$ & $\begin{array}{c}71.91 \\
0.61 \\
16.05 \\
2.7 \\
0 \\
0.36 \\
2.22 \\
3.22 \\
2.93 \\
97.84\end{array}$ & $\begin{array}{c}71.9 \\
0.57 \\
15.97 \\
2.86 \\
0 \\
0.45 \\
2.19 \\
2.92 \\
3.14 \\
96.61\end{array}$ & $\begin{array}{r}72.97 \\
0.49 \\
15.92 \\
2.46 \\
0 \\
0.22 \\
1.83 \\
3.12 \\
2.99 \\
98.43\end{array}$ & $\begin{array}{r}72.29 \\
0.64 \\
15.92 \\
2.53 \\
0 \\
0.38 \\
1.84 \\
3.28 \\
3.12 \\
98.69\end{array}$ & $\begin{array}{c}72.84 \\
0.7 \\
15.77 \\
2.5 \\
0 \\
0.21 \\
1.84 \\
3.19 \\
2.95 \\
96.06\end{array}$ \\
\hline $\begin{array}{l}\text { UNE number: } \\
\text { Core, section: } \\
\text { Interval }(\mathrm{cm}):\end{array}$ & $\begin{array}{c}80 \\
24 \mathrm{H}-4 \\
144-145 \\
\end{array}$ & $\begin{array}{c}82 \\
38 \mathrm{H}-4 \\
116-117 \\
\end{array}$ & $\begin{array}{c}82 \\
38 \mathrm{H}-4 \\
116-117 \\
\end{array}$ & $\begin{array}{c}82 \\
38 \mathrm{H}-4 \\
116-117 \\
\end{array}$ & $\begin{array}{c}82 \\
38 \mathrm{H}-4 \\
116-117 \\
\end{array}$ & $\begin{array}{c}82 \\
38 \mathrm{H}-4 \\
116-117 \\
\end{array}$ & $\begin{array}{c}83 \\
39 \mathrm{H}-7 \\
24-25\end{array}$ & $\begin{array}{c}83 \\
39 \mathrm{H}-7 \\
24-25\end{array}$ & $\begin{array}{c}83 \\
39 \mathrm{H}-7 \\
24-25\end{array}$ & $\begin{array}{c}83 \\
39 \mathrm{H}-7 \\
24-25 \\
\end{array}$ & $\begin{array}{c}83 \\
39 \mathrm{H}-7 \\
24-25 \\
\end{array}$ & $\begin{array}{c}83 \\
39 \mathrm{H}-7 \\
24-25 \\
\end{array}$ & $\begin{array}{c}84 \\
41 \mathrm{H}-1 \\
120-121\end{array}$ & $\begin{array}{c}84 \\
41 \mathrm{H}-1 \\
120-121\end{array}$ & $\begin{array}{c}84 \\
41 \mathrm{H}-1 \\
120-121\end{array}$ & $\begin{array}{c}85 \\
42 \mathrm{H}-2 \\
130-131 \\
\end{array}$ \\
\hline $\begin{array}{l}\mathrm{SiO}_{2} \\
\mathrm{TiO}_{2} \\
\mathrm{Al}_{2} \mathrm{O}_{3} \\
\mathrm{FeO}_{3} \\
\mathrm{MnO} \\
\mathrm{MgO} \\
\mathrm{CgO} \\
\mathrm{K}_{2} \mathrm{O} \\
\mathrm{Na}_{2} \mathrm{O} \\
\text { Total }\end{array}$ & $\begin{array}{c}73 \\
0.62 \\
15.54 \\
2.61 \\
0 \\
0.28 \\
1.92 \\
3.22 \\
2.81 \\
96.69\end{array}$ & $\begin{array}{c}73.6 \\
0.29 \\
14.73 \\
1.9 \\
0 \\
0.13 \\
1.45 \\
4.48 \\
3.41 \\
98.58\end{array}$ & $\begin{array}{c}74.98 \\
0.17 \\
14.36 \\
1.6 \\
0 \\
0 \\
1.17 \\
4.35 \\
3.37 \\
97.09\end{array}$ & $\begin{array}{c}75.76 \\
0 \\
14.09 \\
1.34 \\
0 \\
0 \\
0.86 \\
4.63 \\
36.32 \\
96.57\end{array}$ & $\begin{array}{c}76.18 \\
0 \\
13.91 \\
1.25 \\
0 \\
0 \\
0.7 \\
4.76 \\
3.19 \\
97.15\end{array}$ & $\begin{array}{c}75.56 \\
0.15 \\
14 \\
1.4 \\
0 \\
0 \\
0.95 \\
4.66 \\
3.28 \\
97.95\end{array}$ & $\begin{array}{r}77.22 \\
0.36 \\
13.41 \\
1.61 \\
0 \\
0 \\
1.05 \\
3.81 \\
2.55 \\
98.22\end{array}$ & $\begin{array}{c}76.55 \\
0.31 \\
13 \\
1.7 \\
0 \\
0 \\
1.06 \\
3.58 \\
38.8 \\
98.62\end{array}$ & $\begin{array}{c}76.15 \\
0.25 \\
13.04 \\
1.79 \\
0 \\
0 \\
1.02 \\
3.86 \\
38.9 \\
98.63\end{array}$ & $\begin{array}{c}76.56 \\
0.26 \\
12.83 \\
1.76 \\
0 \\
0 \\
1.1 \\
3.83 \\
3.63 \\
98.27\end{array}$ & $\begin{array}{r}76.11 \\
0.25 \\
12.99 \\
1.88 \\
0 \\
0 \\
1.09 \\
3.78 \\
38.89 \\
98.19\end{array}$ & $\begin{array}{c}76.49 \\
0.19 \\
13.11 \\
1.7 \\
0 \\
0 \\
1.05 \\
3.8 \\
3.67 \\
97.98\end{array}$ & $\begin{array}{c}78.72 \\
0 \\
12.37 \\
0.75 \\
0 \\
0 \\
0.66 \\
4.32 \\
3.19 \\
95.92\end{array}$ & $\begin{array}{c}78.86 \\
0 \\
11.94 \\
0.78 \\
0 \\
0 \\
0.59 \\
4.66 \\
3.17 \\
95.82\end{array}$ & $\begin{array}{c}79.31 \\
0 \\
12.01 \\
0.55 \\
0 \\
0 \\
0.52 \\
4.7 \\
2.91 \\
94.08\end{array}$ & $\begin{array}{c}78.4 \\
0 \\
12.46 \\
1 \\
0 \\
0 \\
0.78 \\
4.16 \\
3.2 \\
97.83\end{array}$ \\
\hline $\begin{array}{l}\text { UNE number: } \\
\text { Core, section: } \\
\text { Interval }(\mathrm{cm}) \text { : }\end{array}$ & $\begin{array}{c}85 \\
42 \mathrm{H}-2 \\
130-131 \\
\end{array}$ & $\begin{array}{c}85 \\
42 \mathrm{H}-2 \\
130-131 \\
\end{array}$ & $\begin{array}{c}85 \\
42 \mathrm{H}-2 \\
130-131 \\
\end{array}$ & $\begin{array}{c}85 \\
42 \mathrm{H}-2 \\
130-131\end{array}$ & $\begin{array}{c}85 \\
42 \mathrm{H}-2 \\
130-131 \\
\end{array}$ & $\begin{array}{c}85 \\
42 \mathrm{H}-2 \\
130-131 \\
\end{array}$ & $\begin{array}{c}86 \\
42 \mathrm{H}-4 \\
55-56\end{array}$ & $\begin{array}{c}86 \\
42 \mathrm{H}-4 \\
55-56\end{array}$ & $\begin{array}{c}86 \\
42 \mathrm{H}-4 \\
55-56 \\
\end{array}$ & $\begin{array}{c}86 \\
42 \mathrm{H}-4 \\
55-56 \\
\end{array}$ & $\begin{array}{c}86 \\
42 \mathrm{H}-4 \\
55-56 \\
\end{array}$ & & & & & \\
\hline $\begin{array}{l}\mathrm{SiO}_{2} \\
\mathrm{TiO}_{2} \\
\mathrm{Al}_{2} \mathrm{O}_{3} \\
\mathrm{FeO}^{*} \\
\mathrm{MnO} \\
\mathrm{MgO} \\
\mathrm{CaO} \\
\mathrm{K}_{2} \mathrm{O} \\
\mathrm{Na}_{2} \mathrm{O} \\
\text { Total }\end{array}$ & $\begin{array}{c}78.36 \\
0 \\
12.54 \\
0.99 \\
0 \\
0 \\
0.69 \\
4.37 \\
3.05 \\
96.28\end{array}$ & $\begin{array}{c}78.56 \\
0 \\
12.3 \\
1.03 \\
0 \\
0 \\
0.81 \\
4.07 \\
3.23 \\
96.79\end{array}$ & $\begin{array}{l}78.59 \\
0 \\
12.46 \\
1.05 \\
0 \\
0 \\
0.79 \\
3.91 \\
3.21 \\
95.52\end{array}$ & $\begin{array}{c}78.54 \\
0 \\
12.39 \\
1.07 \\
0 \\
0 \\
0.79 \\
3.8 \\
3.4 \\
96.48\end{array}$ & $\begin{array}{r}78.05 \\
0.15 \\
12.49 \\
1.06 \\
0 \\
0 \\
0.69 \\
4.18 \\
3.38 \\
97.73\end{array}$ & $\begin{array}{c}78.33 \\
0 \\
12.44 \\
0.99 \\
0 \\
0 \\
0.91 \\
3.92 \\
3.41 \\
96.52\end{array}$ & $\begin{array}{c}79.57 \\
0 \\
12.43 \\
0.77 \\
0 \\
0 \\
0.58 \\
4.12 \\
2.53 \\
98.22\end{array}$ & $\begin{array}{l}80.5 \\
0 \\
12.6 \\
0.62 \\
0 \\
0 \\
0.45 \\
3.77 \\
2.05 \\
96.27\end{array}$ & $\begin{array}{c}80.16 \\
0 \\
12.51 \\
0.55 \\
0 \\
0 \\
0.43 \\
3.92 \\
2.42 \\
97.78\end{array}$ & $\begin{array}{c}80.2 \\
0 \\
12.5 \\
0.67 \\
0 \\
0 \\
0.38 \\
3.96 \\
2.29 \\
96.8\end{array}$ & $\begin{array}{l}79.91 \\
0 \\
12.57 \\
0.6 \\
0 \\
0 \\
0.45 \\
3.82 \\
2.65 \\
97.54\end{array}$ & & & & & \\
\hline
\end{tabular}


Table 7. Representative analyses of vitric shards from Hole 883B.

\begin{tabular}{|c|c|c|c|c|c|c|c|c|c|c|c|c|c|c|c|c|c|}
\hline $\begin{array}{l}\text { UNE number: } \\
\text { Core, section: } \\
\text { Interval }(\mathrm{cm}) \text { : }\end{array}$ & $\begin{array}{c}87 \\
1 \mathrm{H}-2 \\
107-108 \\
\end{array}$ & $\begin{array}{c}87 \\
1 \mathrm{H}-2 \\
107-108 \\
\end{array}$ & $\begin{array}{c}87 \\
1 \mathrm{H}-2 \\
107-108 \\
\end{array}$ & $\begin{array}{c}89 \\
2 \mathrm{H}-1 \\
67-70\end{array}$ & $\begin{array}{c}89 \\
2 \mathrm{H}-1 \\
67-70\end{array}$ & $\begin{array}{c}89 \\
2 \mathrm{H}-1 \\
67-70\end{array}$ & $\begin{array}{c}89 \\
2 \mathrm{H}-1 \\
67-70\end{array}$ & $\begin{array}{c}89 \\
2 \mathrm{H}-1 \\
67-70\end{array}$ & $\begin{array}{c}89 \\
2 \mathrm{H}-1 \\
67-70 \\
\end{array}$ & $\begin{array}{c}89 \\
2 \mathrm{H}-1 \\
67-70 \\
\end{array}$ & $\begin{array}{c}91 \\
3 \mathrm{H}-4 \\
102-103 \\
\end{array}$ & $\begin{array}{c}92 \\
3 \mathrm{H}-6 \\
67-68 \\
\end{array}$ & $\begin{array}{c}92 \\
3 \mathrm{H}-06 \\
67-68 \\
\end{array}$ & $\begin{array}{c}92 \\
3 \mathrm{H}-06 \\
67-68 \\
\end{array}$ & $\begin{array}{c}92 \\
3 \mathrm{H}-06 \\
67-68 \\
\end{array}$ & $\begin{array}{c}92 \\
3 \mathrm{H}-06 \\
67-68 \\
\end{array}$ & $\begin{array}{c}92 \\
3 \mathrm{H}-06 \\
67-68 \\
\end{array}$ \\
\hline $\begin{array}{l}\mathrm{SiO}_{2} \\
\mathrm{TiO}_{2} \\
\mathrm{Al}_{2} \mathrm{O}_{3} \\
\mathrm{FeO}^{*} \\
\mathrm{MnO} \\
\mathrm{MgO} \\
\mathrm{CaO} \\
\mathrm{K}_{2} \mathrm{O} \\
\mathrm{Na}_{2} \mathrm{O} \\
\text { Total }\end{array}$ & $\begin{array}{r}73.89 \\
0.50 \\
15.01 \\
2.40 \\
0.00 \\
0.00 \\
1.43 \\
3.72 \\
3.05 \\
98.12\end{array}$ & $\begin{array}{r}74.31 \\
0.56 \\
14.95 \\
2.38 \\
0.00 \\
0.00 \\
1.37 \\
3.79 \\
2.65 \\
98.64\end{array}$ & $\begin{array}{r}73.92 \\
0.60 \\
15.05 \\
2.18 \\
0.00 \\
0.00 \\
1.33 \\
3.77 \\
3.14 \\
98.84\end{array}$ & $\begin{array}{r}75.54 \\
0.58 \\
15.62 \\
2.14 \\
0.00 \\
0.00 \\
1.33 \\
3.26 \\
1.89 \\
96.48\end{array}$ & $\begin{array}{r}74.64 \\
0.59 \\
15.13 \\
2.04 \\
0.00 \\
0.00 \\
1.35 \\
3.37 \\
2.87 \\
97.61\end{array}$ & $\begin{array}{r}74.39 \\
0.56 \\
15.32 \\
2.18 \\
0.00 \\
0.00 \\
1.16 \\
3.37 \\
3.02 \\
98.56\end{array}$ & $\begin{array}{r}69.93 \\
0.90 \\
16.25 \\
3.81 \\
0.00 \\
0.61 \\
2.75 \\
2.73 \\
3.04 \\
98.15\end{array}$ & $\begin{array}{r}74.09 \\
0.53 \\
15.17 \\
2.41 \\
0.00 \\
0.00 \\
1.37 \\
3.31 \\
3.12 \\
98.73\end{array}$ & $\begin{array}{r}74.88 \\
0.53 \\
15.08 \\
2.06 \\
0.00 \\
0.00 \\
1.35 \\
3.32 \\
2.77 \\
97.28\end{array}$ & $\begin{array}{r}74.45 \\
0.53 \\
15.28 \\
2.48 \\
0.00 \\
0.00 \\
1.49 \\
3.10 \\
2.67 \\
97.16\end{array}$ & $\begin{array}{r}65.01 \\
1.42 \\
15.39 \\
8.55 \\
0.00 \\
0.36 \\
3.59 \\
2.93 \\
2.74 \\
98.39\end{array}$ & $\begin{array}{r}79.61 \\
0.00 \\
12.42 \\
0.69 \\
0.00 \\
0.00 \\
0.84 \\
3.71 \\
2.73 \\
95.80\end{array}$ & $\begin{array}{r}80.11 \\
0.00 \\
12.45 \\
0.66 \\
0.00 \\
0.00 \\
0.64 \\
3.47 \\
2.67 \\
95.36\end{array}$ & $\begin{array}{r}79.69 \\
0.00 \\
12.43 \\
0.74 \\
0.00 \\
0.00 \\
0.78 \\
3.69 \\
2.69 \\
95.87\end{array}$ & $\begin{array}{r}80.64 \\
0.00 \\
12.39 \\
0.56 \\
0.00 \\
0.00 \\
0.61 \\
3.28 \\
2.53 \\
95.93\end{array}$ & $\begin{array}{r}79.92 \\
0.00 \\
12.28 \\
0.77 \\
0.00 \\
0.00 \\
0.78 \\
3.57 \\
2.68 \\
95.92\end{array}$ & $\begin{array}{r}79.99 \\
0.00 \\
12.25 \\
0.78 \\
0.00 \\
0.00 \\
0.72 \\
3.52 \\
2.75 \\
95.68\end{array}$ \\
\hline $\begin{array}{l}\text { UNE number: } \\
\text { Core, section: } \\
\text { Interval }(\mathrm{cm}) \text { : }\end{array}$ & $\begin{array}{c}92 \\
3 \mathrm{H}-06 \\
67-68 \\
\end{array}$ & $\begin{array}{c}93 \\
4 \mathrm{H}-03 \\
25-26 \\
\end{array}$ & $\begin{array}{c}93 \\
4 H-03 \\
25-26 \\
\end{array}$ & $\begin{array}{c}93 \\
4 H-3 \\
25-26 \\
\end{array}$ & $\begin{array}{c}93 \\
4 \mathrm{H}-3 \\
25-26 \\
\end{array}$ & $\begin{array}{c}94 \\
5 \mathrm{H}-4 \\
56-57 \\
\end{array}$ & $\begin{array}{c}95 \\
6 \mathrm{H}-1 \\
40-41 \\
\end{array}$ & $\begin{array}{c}95 \\
6 H-1 \\
40-41 \\
\end{array}$ & $\begin{array}{c}95 \\
6 \mathrm{H}-1 \\
40-41 \\
\end{array}$ & $\begin{array}{c}95 \\
6 \mathrm{H}-1 \\
40-41 \\
\end{array}$ & $\begin{array}{c}95 \\
6 \mathrm{H}-1 \\
40-41 \\
\end{array}$ & $\begin{array}{c}95 \\
6 \mathrm{H}-1 \\
40-41 \\
\end{array}$ & $\begin{array}{c}95 \\
6 \mathrm{H}-1 \\
40-41 \\
\end{array}$ & $\begin{array}{c}96 \\
6 \mathrm{H}-2 \\
70-71 \\
\end{array}$ & $\begin{array}{c}96 \\
6 \mathrm{H}-2 \\
70-71 \\
\end{array}$ & $\begin{array}{c}96 \\
6 \mathrm{H}-2 \\
70-71 \\
\end{array}$ & $\begin{array}{c}96 \\
6 \mathrm{H}-2 \\
70-71 \\
\end{array}$ \\
\hline $\begin{array}{l}\mathrm{SiO}_{2} \\
\mathrm{TiO}_{2} \\
\mathrm{Al}_{2} \mathrm{O}_{3} \\
\mathrm{FeO}^{2} \\
\mathrm{MnO} \\
\mathrm{MgO} \\
\mathrm{CaO} \\
\mathrm{K}_{2} \mathrm{O} \\
\mathrm{Na}_{2} \mathrm{O} \\
\text { Total }\end{array}$ & $\begin{array}{r}80.00 \\
0.13 \\
12.15 \\
0.73 \\
0.00 \\
0.00 \\
0.76 \\
3.49 \\
2.73 \\
96.79\end{array}$ & $\begin{array}{r}72.54 \\
0.60 \\
14.43 \\
3.47 \\
0.00 \\
0.29 \\
2.27 \\
2.33 \\
4.08 \\
97.19\end{array}$ & $\begin{array}{r}75.54 \\
0.15 \\
13.59 \\
2.23 \\
0.00 \\
0.00 \\
1.27 \\
2.88 \\
4.34 \\
96.50\end{array}$ & $\begin{array}{r}75.87 \\
0.67 \\
12.31 \\
3.13 \\
0.00 \\
0.00 \\
1.65 \\
3.09 \\
3.29 \\
99.04\end{array}$ & $\begin{array}{r}71.50 \\
0.67 \\
14.73 \\
3.46 \\
0.00 \\
0.37 \\
2.49 \\
2.07 \\
4.72 \\
98.59\end{array}$ & $\begin{array}{r}72.58 \\
0.55 \\
13.91 \\
3.77 \\
0.00 \\
0.43 \\
2.83 \\
1.76 \\
4.18 \\
97.78\end{array}$ & $\begin{array}{r}74.82 \\
0.42 \\
14.24 \\
2.53 \\
0.00 \\
0.23 \\
2.10 \\
2.95 \\
2.72 \\
97.29\end{array}$ & $\begin{array}{r}74.09 \\
0.54 \\
14.70 \\
2.56 \\
0.00 \\
0.28 \\
2.42 \\
2.83 \\
2.58 \\
97.85\end{array}$ & $\begin{array}{r}75.05 \\
0.46 \\
14.27 \\
2.36 \\
0.00 \\
0.15 \\
2.03 \\
2.79 \\
2.88 \\
98.10\end{array}$ & $\begin{array}{r}74.90 \\
0.56 \\
14.05 \\
2.52 \\
0.00 \\
0.20 \\
2.14 \\
2.93 \\
2.71 \\
98.02\end{array}$ & $\begin{array}{r}75.58 \\
0.45 \\
14.11 \\
2.39 \\
0.00 \\
0.15 \\
2.13 \\
2.81 \\
2.38 \\
98.00\end{array}$ & $\begin{array}{r}73.66 \\
0.68 \\
14.61 \\
2.88 \\
0.00 \\
0.37 \\
2.23 \\
2.85 \\
2.72 \\
98.97\end{array}$ & $\begin{array}{r}75.73 \\
0.52 \\
14.16 \\
2.19 \\
0.00 \\
0.15 \\
2.05 \\
2.79 \\
2.41 \\
97.24\end{array}$ & $\begin{array}{r}77.44 \\
0.00 \\
13.41 \\
2.21 \\
0.00 \\
0.00 \\
0.74 \\
3.88 \\
2.33 \\
97.96\end{array}$ & $\begin{array}{r}76.81 \\
0.23 \\
13.33 \\
2.63 \\
0.00 \\
0.00 \\
1.32 \\
2.93 \\
2.74 \\
98.60\end{array}$ & $\begin{array}{r}76.81 \\
0.25 \\
13.40 \\
2.63 \\
0.00 \\
0.00 \\
1.43 \\
2.85 \\
2.63 \\
97.60\end{array}$ & $\begin{array}{r}77.07 \\
0.17 \\
13.21 \\
2.87 \\
0.00 \\
0.00 \\
1.37 \\
2.84 \\
2.45 \\
96.61\end{array}$ \\
\hline $\begin{array}{l}\text { UNE number: } \\
\text { Core, section: } \\
\text { Interval }(\mathrm{cm}) \text { : }\end{array}$ & $\begin{array}{c}96 \\
6 \mathrm{H}-2 \\
70-71 \\
\end{array}$ & $\begin{array}{c}96 \\
6 \mathrm{H}-2 \\
70-71 \\
\end{array}$ & $\begin{array}{c}96 \\
6 \mathrm{H}-2 \\
70-71 \\
\end{array}$ & $\begin{array}{c}97 \\
6 \mathrm{H}-3 \\
87-88 \\
\end{array}$ & $\begin{array}{c}97 \\
6 \mathrm{H}-3 \\
87-88 \\
\end{array}$ & $\begin{array}{c}97 \\
6 \mathrm{H}-3 \\
87-88 \\
\end{array}$ & $\begin{array}{c}97 \\
6 \mathrm{H}-3 \\
87-88 \\
\end{array}$ & $\begin{array}{c}98 \\
7 \mathrm{H}-6 \\
28-30 \\
\end{array}$ & $\begin{array}{c}98 \\
7 \mathrm{H}-6 \\
28-30 \\
\end{array}$ & $\begin{array}{c}98 \\
7 \mathrm{H}-6 \\
28-30\end{array}$ & $\begin{array}{c}98 \\
7 \mathrm{H}-6 \\
28-30\end{array}$ & $\begin{array}{c}98 \\
7 \mathrm{H}-6 \\
28-30 \\
\end{array}$ & $\begin{array}{c}99 \\
7 \mathrm{H}-6 \\
71-72\end{array}$ & $\begin{array}{c}99 \\
7 \mathrm{H}-6 \\
71-72 \\
\end{array}$ & $\begin{array}{c}99 \\
7 \mathrm{H}-6 \\
71-72\end{array}$ & $\begin{array}{c}99 \\
7 \mathrm{H}-6 \\
71-72 \\
\end{array}$ & $\begin{array}{c}99 \\
7 \mathrm{H}-6 \\
71-72 \\
\end{array}$ \\
\hline $\begin{array}{l}\mathrm{SiO}_{2} \\
\mathrm{TiO}_{2} \\
\mathrm{Al}_{2} \mathrm{O}_{3} \\
\mathrm{FeO}^{*} \\
\mathrm{MnO} \\
\mathrm{MgO} \\
\mathrm{CaO} \\
\mathrm{K}_{2} \mathrm{O} \\
\mathrm{Na}_{2} \mathrm{O} \\
\mathrm{Total}\end{array}$ & $\begin{array}{r}76.83 \\
0.31 \\
13.44 \\
2.58 \\
0.00 \\
0.00 \\
1.32 \\
2.82 \\
2.70 \\
98.40\end{array}$ & $\begin{array}{r}76.84 \\
0.24 \\
13.48 \\
2.68 \\
0.00 \\
0.00 \\
1.38 \\
2.81 \\
2.57 \\
96.19\end{array}$ & $\begin{array}{r}76.78 \\
0.23 \\
13.24 \\
2.72 \\
0.00 \\
0.00 \\
1.47 \\
2.80 \\
2.77 \\
97.84\end{array}$ & $\begin{array}{r}73.07 \\
0.45 \\
14.49 \\
3.36 \\
0.00 \\
0.17 \\
2.37 \\
3.06 \\
2.74 \\
97.83\end{array}$ & $\begin{array}{r}74.82 \\
0.35 \\
14.19 \\
3.08 \\
0.00 \\
0.00 \\
1.86 \\
3.09 \\
2.61 \\
96.92\end{array}$ & $\begin{array}{r}74.58 \\
0.40 \\
14.19 \\
3.21 \\
0.00 \\
0.00 \\
1.80 \\
2.91 \\
2.91 \\
96.81\end{array}$ & $\begin{array}{r}74.65 \\
0.36 \\
14.20 \\
3.17 \\
0.00 \\
0.00 \\
1.96 \\
3.10 \\
2.56 \\
96.09\end{array}$ & $\begin{array}{r}75.06 \\
0.65 \\
13.41 \\
2.50 \\
0.00 \\
0.16 \\
2.26 \\
2.55 \\
3.40 \\
97.44\end{array}$ & $\begin{array}{r}74.28 \\
0.68 \\
13.83 \\
2.78 \\
0.00 \\
0.23 \\
2.61 \\
2.56 \\
3.02 \\
98.22\end{array}$ & $\begin{array}{r}74.28 \\
0.68 \\
13.83 \\
2.78 \\
0.00 \\
0.23 \\
2.61 \\
2.56 \\
3.02 \\
98.22\end{array}$ & $\begin{array}{r}74.75 \\
0.50 \\
13.83 \\
2.74 \\
0.00 \\
0.19 \\
2.47 \\
2.44 \\
3.08 \\
96.44\end{array}$ & $\begin{array}{r}76.38 \\
0.51 \\
13.23 \\
2.36 \\
0.00 \\
0.00 \\
2.09 \\
2.61 \\
2.81 \\
96.92\end{array}$ & $\begin{array}{r}73.82 \\
0.76 \\
14.21 \\
3.34 \\
0.00 \\
0.22 \\
2.81 \\
2.11 \\
2.75 \\
96.52\end{array}$ & $\begin{array}{r}73.84 \\
0.57 \\
14.10 \\
3.40 \\
0.00 \\
0.21 \\
2.82 \\
2.16 \\
2.91 \\
98.06\end{array}$ & $\begin{array}{r}74.32 \\
0.56 \\
14.18 \\
3.32 \\
0.00 \\
0.32 \\
2.61 \\
2.26 \\
2.42 \\
95.56\end{array}$ & $\begin{array}{r}74.59 \\
0.59 \\
14.24 \\
3.19 \\
0.00 \\
0.00 \\
2.72 \\
2.09 \\
2.59 \\
97.38\end{array}$ & $\begin{array}{r}74.07 \\
0.57 \\
14.03 \\
3.41 \\
0.00 \\
0.41 \\
3.11 \\
2.08 \\
2.33 \\
97.01\end{array}$ \\
\hline $\begin{array}{l}\text { UNE number: } \\
\text { Core, section: } \\
\text { Interval }(\mathrm{cm}) \text { : }\end{array}$ & $\begin{array}{c}99 \\
7 \mathrm{H}-6 \\
71-72 \\
\end{array}$ & $\begin{array}{c}100 \\
8 \mathrm{H}-3 \\
129-130 \\
\end{array}$ & $\begin{array}{c}100 \\
8 \mathrm{H}-3 \\
129-130 \\
\end{array}$ & $\begin{array}{c}100 \\
8 \mathrm{H}-3 \\
129-130 \\
\end{array}$ & $\begin{array}{c}100 \\
8 \mathrm{H}-3 \\
129-130 \\
\end{array}$ & $\begin{array}{c}100 \\
8 \mathrm{H}-3 \\
129-130 \\
\end{array}$ & $\begin{array}{c}100 \\
8 \mathrm{H}-3 \\
129-130 \\
\end{array}$ & $\begin{array}{c}100 \\
8 \mathrm{H}-3 \\
129-130 \\
\end{array}$ & $\begin{array}{c}100 \\
8 \mathrm{H}-3 \\
129-130\end{array}$ & $\begin{array}{c}103 \\
9 \mathrm{H}-6 \\
27-28\end{array}$ & $\begin{array}{c}103 \\
9 \mathrm{H}-6 \\
27-28\end{array}$ & $\begin{array}{c}103 \\
9 \mathrm{H}-6 \\
27-28 \\
\end{array}$ & $\begin{array}{c}103 \\
9 \mathrm{H}-6 \\
27-28\end{array}$ & $\begin{array}{c}103 \\
9 \mathrm{H}-6 \\
27-28\end{array}$ & $\begin{array}{c}103 \\
9 \mathrm{H}-6 \\
27-28\end{array}$ & $\begin{array}{c}103 \\
9 \mathrm{H}-6 \\
27-28\end{array}$ & $\begin{array}{c}104 \\
10 \mathrm{H}-1 \\
35-36\end{array}$ \\
\hline $\begin{array}{l}\mathrm{SiO}_{2} \\
\mathrm{TiO}_{2} \\
\mathrm{Al}_{2} \mathrm{O}_{3} \\
\mathrm{FOO}^{4} \\
\mathrm{MnO} \\
\mathrm{MgO} \\
\mathrm{CaO} \\
\mathrm{K}_{2} \mathrm{O} \\
\mathrm{Na}_{2} \mathrm{O} \\
\mathrm{Total}\end{array}$ & $\begin{array}{r}74.13 \\
0.55 \\
14.01 \\
3.34 \\
0.00 \\
0.32 \\
2.84 \\
2.14 \\
2.66 \\
97.33\end{array}$ & $\begin{array}{r}70.47 \\
0.67 \\
14.05 \\
4.65 \\
0.00 \\
0.44 \\
3.14 \\
2.61 \\
3.96 \\
97.48\end{array}$ & $\begin{array}{r}67.90 \\
1.04 \\
14.52 \\
5.78 \\
0.00 \\
0.84 \\
4.05 \\
2.28 \\
3.59 \\
97.02\end{array}$ & $\begin{array}{r}71.13 \\
0.77 \\
14.56 \\
4.10 \\
0.00 \\
0.46 \\
2.99 \\
2.78 \\
2.61 \\
79.80\end{array}$ & $\begin{array}{r}70.40 \\
0.80 \\
14.45 \\
4.58 \\
0.00 \\
0.48 \\
3.23 \\
2.65 \\
3.42 \\
98.40\end{array}$ & $\begin{array}{r}71.25 \\
0.72 \\
14.54 \\
4.72 \\
0.00 \\
0.48 \\
3.26 \\
2.34 \\
2.68 \\
96.33\end{array}$ & $\begin{array}{r}72.69 \\
0.67 \\
14.24 \\
4.17 \\
0.00 \\
0.24 \\
2.82 \\
2.40 \\
2.77 \\
95.93\end{array}$ & $\begin{array}{r}71.37 \\
0.67 \\
14.14 \\
4.45 \\
0.00 \\
0.40 \\
3.24 \\
2.50 \\
3.22 \\
98.32\end{array}$ & $\begin{array}{r}71.86 \\
0.69 \\
14.35 \\
4.81 \\
0.00 \\
0.34 \\
2.91 \\
2.49 \\
2.55 \\
98.52\end{array}$ & $\begin{array}{r}75.26 \\
0.39 \\
13.36 \\
3.30 \\
0.00 \\
0.00 \\
1.83 \\
2.69 \\
3.18 \\
97.07\end{array}$ & $\begin{array}{r}75.05 \\
0.52 \\
13.26 \\
3.22 \\
0.00 \\
0.00 \\
1.82 \\
2.70 \\
3.43 \\
98.50\end{array}$ & $\begin{array}{r}75.63 \\
0.37 \\
13.39 \\
3.14 \\
0.00 \\
0.00 \\
1.82 \\
2.58 \\
3.08 \\
96.94\end{array}$ & $\begin{array}{r}74.82 \\
0.45 \\
13.43 \\
3.11 \\
0.00 \\
0.00 \\
1.99 \\
2.71 \\
3.50 \\
98.38\end{array}$ & $\begin{array}{r}75.53 \\
0.46 \\
12.96 \\
3.18 \\
0.00 \\
0.00 \\
1.88 \\
2.66 \\
3.32 \\
98.33\end{array}$ & $\begin{array}{r}75.44 \\
0.38 \\
13.11 \\
3.18 \\
0.00 \\
0.00 \\
1.67 \\
2.73 \\
3.48 \\
97.92\end{array}$ & $\begin{array}{r}74.94 \\
0.49 \\
13.35 \\
3.38 \\
0.00 \\
0.00 \\
1.92 \\
2.61 \\
3.31 \\
98.26\end{array}$ & $\begin{array}{r}71.40 \\
0.60 \\
13.60 \\
4.34 \\
0.00 \\
0.40 \\
3.12 \\
1.95 \\
4.59 \\
98.14\end{array}$ \\
\hline
\end{tabular}


Table 7 (continued).

\begin{tabular}{|c|c|c|c|c|c|c|c|c|c|c|c|c|c|c|c|c|c|}
\hline $\begin{array}{l}\text { UNE number: } \\
\text { Core, section: } \\
\text { Interval }(\mathrm{cm}) \text { : }\end{array}$ & $\begin{array}{c}104 \\
10 \mathrm{H}-1 \\
35-36\end{array}$ & $\begin{array}{c}104 \\
10 \mathrm{H}-1 \\
35-36 \\
\end{array}$ & $\begin{array}{c}104 \\
10 \mathrm{H}-1 \\
35-36 \\
\end{array}$ & $\begin{array}{c}104 \\
10 \mathrm{H}-1 \\
35-36 \\
\end{array}$ & $\begin{array}{c}105 \\
13 \mathrm{H}-3 \\
19-20 \\
\end{array}$ & $\begin{array}{c}105 \\
13 \mathrm{H}-3 \\
19-20 \\
\end{array}$ & $\begin{array}{c}105 \\
13 \mathrm{H}-3 \\
19-20 \\
\end{array}$ & $\begin{array}{c}105 \\
13 \mathrm{H}-3 \\
19-20 \\
\end{array}$ & $\begin{array}{c}105 \\
13 \mathrm{H}-3 \\
19-20 \\
\end{array}$ & $\begin{array}{c}105 \\
13 \mathrm{H}-3 \\
19-20 \\
\end{array}$ & $\begin{array}{c}105 \\
13 \mathrm{H}-3 \\
19-20\end{array}$ & $\begin{array}{c}106 \\
14 \mathrm{H}-1 \\
67-68\end{array}$ & $\begin{array}{c}106 \\
14 \mathrm{H}-1 \\
67-68 \\
\end{array}$ & $\begin{array}{c}108 \\
21 \mathrm{H}-5 \\
136-137\end{array}$ & $\begin{array}{c}108 \\
21 \mathrm{H}-5 \\
136-137 \\
\end{array}$ & $\begin{array}{c}108 \\
21 \mathrm{H}-5 \\
136-137\end{array}$ & $\begin{array}{c}108 \\
21 \mathrm{H}-5 \\
136-137 \\
\end{array}$ \\
\hline $\begin{array}{l}\mathrm{SiO}_{2} \\
\mathrm{TiO}_{2} \\
\mathrm{Al}_{2} \mathrm{O}_{3} \\
\mathrm{FeO}^{*} \\
\mathrm{MnO} \\
\mathrm{MgO} \\
\mathrm{CaO} \\
\mathrm{K}_{2} \mathrm{O} \\
\mathrm{Na}_{2} \mathrm{O} \\
\mathrm{Total}^{2}\end{array}$ & $\begin{array}{r}66.28 \\
0.57 \\
14.74 \\
6.75 \\
0.00 \\
1.40 \\
5.03 \\
1.40 \\
3.84 \\
98.53\end{array}$ & $\begin{array}{r}66.66 \\
0.78 \\
14.66 \\
6.33 \\
0.00 \\
1.25 \\
4.75 \\
1.49 \\
4.07 \\
99.11\end{array}$ & $\begin{array}{r}73.18 \\
0.41 \\
13.04 \\
4.12 \\
0.00 \\
0.00 \\
2.34 \\
1.99 \\
4.92 \\
98.36\end{array}$ & $\begin{array}{r}73.84 \\
0.25 \\
13.06 \\
3.99 \\
0.00 \\
0.00 \\
2.39 \\
1.94 \\
4.54 \\
97.58\end{array}$ & $\begin{array}{r}78.11 \\
0.00 \\
13.61 \\
1.84 \\
0.00 \\
0.00 \\
1.74 \\
1.49 \\
3.22 \\
93.46\end{array}$ & $\begin{array}{r}71.83 \\
0.94 \\
15.43 \\
4.01 \\
0.00 \\
0.46 \\
3.40 \\
1.30 \\
2.64 \\
96.92\end{array}$ & $\begin{array}{r}78.21 \\
0.25 \\
13.60 \\
1.87 \\
0.00 \\
0.00 \\
1.84 \\
1.47 \\
2.77 \\
95.94\end{array}$ & $\begin{array}{r}78.42 \\
0.15 \\
13.55 \\
1.66 \\
0.00 \\
0.00 \\
1.78 \\
1.40 \\
3.03 \\
97.58\end{array}$ & $\begin{array}{r}78.02 \\
0.21 \\
13.69 \\
1.83 \\
0.00 \\
0.00 \\
1.81 \\
1.47 \\
2.97 \\
96.81\end{array}$ & $\begin{array}{r}78.51 \\
0.16 \\
13.79 \\
1.71 \\
0.00 \\
0.00 \\
1.87 \\
1.46 \\
2.50 \\
97.47\end{array}$ & $\begin{array}{r}78.69 \\
0.14 \\
13.42 \\
1.89 \\
0.00 \\
0.00 \\
1.75 \\
1.49 \\
2.62 \\
97.37\end{array}$ & $\begin{array}{r}77.12 \\
0.20 \\
14.04 \\
1.33 \\
0.00 \\
0.00 \\
0.97 \\
3.53 \\
2.80 \\
95.14\end{array}$ & $\begin{array}{r}77.80 \\
0.17 \\
13.73 \\
1.07 \\
0.00 \\
0.00 \\
0.85 \\
3.60 \\
2.80 \\
96.33\end{array}$ & $\begin{array}{r}79.27 \\
0.00 \\
12.60 \\
0.42 \\
0.00 \\
0.00 \\
0.51 \\
4.37 \\
2.83 \\
97.07\end{array}$ & $\begin{array}{r}78.97 \\
0.00 \\
12.90 \\
0.43 \\
0.00 \\
0.00 \\
0.54 \\
4.37 \\
2.79 \\
95.70\end{array}$ & $\begin{array}{r}79.48 \\
0.00 \\
12.42 \\
0.38 \\
0.00 \\
0.00 \\
0.49 \\
4.39 \\
2.84 \\
96.33\end{array}$ & $\begin{array}{r}79.14 \\
0.00 \\
12.48 \\
0.48 \\
0.00 \\
0.00 \\
0.55 \\
4.44 \\
2.92 \\
97.79\end{array}$ \\
\hline $\begin{array}{l}\text { UNE number: } \\
\text { Core, section: } \\
\text { Interval (cm): }\end{array}$ & $\begin{array}{c}108 \\
21 \mathrm{H}-5 \\
136-137 \\
\end{array}$ & $\begin{array}{c}109 \\
26 \mathrm{H}-3 \\
86-87 \\
\end{array}$ & $\begin{array}{c}109 \\
26 \mathrm{H}-3 \\
86-87 \\
\end{array}$ & $\begin{array}{c}110 \\
34 X-1 \\
68-69 \\
\end{array}$ & $\begin{array}{c}110 \\
34 X-1 \\
68-69 \\
\end{array}$ & $\begin{array}{c}110 \\
34 X-1 \\
68-69 \\
\end{array}$ & $\begin{array}{c}110 \\
34 X-1 \\
68-69 \\
\end{array}$ & $\begin{array}{c}110 \\
34 X-1 \\
68-69 \\
\end{array}$ & $\begin{array}{c}111 \\
35 X-2 \\
132-133 \\
\end{array}$ & $\begin{array}{c}111 \\
35 X-2 \\
132-133 \\
\end{array}$ & $\begin{array}{c}111 \\
35 X-2 \\
132-133 \\
\end{array}$ & $\begin{array}{c}111 \\
35 X-2 \\
132-133 \\
\end{array}$ & $\begin{array}{c}111 \\
35 X-2 \\
132-133 \\
\end{array}$ & $\begin{array}{c}110 \\
34 X-1 \\
68-69 \\
\end{array}$ & $\begin{array}{c}110 \\
34 X-1 \\
68-69\end{array}$ & $\begin{array}{c}110 \\
34 X-1 \\
68-69 \\
\end{array}$ & $\begin{array}{c}110 \\
34 X-1 \\
68-69 \\
\end{array}$ \\
\hline $\begin{array}{l}\mathrm{SiO}_{2} \\
\mathrm{TiO}_{2} \\
\mathrm{Al}_{2} \mathrm{O}_{3} \\
\mathrm{FeO}^{3} \\
\mathrm{MnO} \\
\mathrm{MgO} \\
\mathrm{CaO} \\
\mathrm{K}_{2} \mathrm{O} \\
\mathrm{Na}_{2} \mathrm{O} \\
\text { Total }\end{array}$ & $\begin{array}{r}79.35 \\
0.00 \\
12.56 \\
0.44 \\
0.00 \\
0.00 \\
0.53 \\
4.35 \\
2.77 \\
95.43\end{array}$ & $\begin{array}{r}78.69 \\
0.14 \\
13.42 \\
1.89 \\
0.00 \\
0.00 \\
1.75 \\
1.49 \\
2.62 \\
97.37\end{array}$ & $\begin{array}{r}61.84 \\
1.00 \\
19.49 \\
5.06 \\
0.00 \\
0.60 \\
6.31 \\
1.76 \\
3.93 \\
95.35\end{array}$ & $\begin{array}{r}80.42 \\
0.22 \\
11.96 \\
0.95 \\
0.00 \\
0.00 \\
0.96 \\
3.31 \\
2.18 \\
96.74\end{array}$ & $\begin{array}{r}80.25 \\
0.00 \\
12.11 \\
1.09 \\
0.00 \\
0.00 \\
1.03 \\
3.25 \\
2.27 \\
96.54\end{array}$ & $\begin{array}{r}80.74 \\
0.00 \\
11.86 \\
1.01 \\
0.00 \\
0.00 \\
1.10 \\
3.04 \\
2.25 \\
96.64\end{array}$ & $\begin{array}{r}75.68 \\
0.23 \\
14.09 \\
1.41 \\
0.00 \\
0.00 \\
1.04 \\
4.79 \\
2.75 \\
96.18\end{array}$ & $\begin{array}{r}72.86 \\
0.43 \\
14.96 \\
3.34 \\
0.00 \\
0.13 \\
1.86 \\
2.71 \\
3.70 \\
95.98\end{array}$ & $\begin{array}{r}77.43 \\
0.21 \\
13.12 \\
1.74 \\
0.00 \\
0.00 \\
1.04 \\
3.77 \\
2.69 \\
95.85\end{array}$ & $\begin{array}{r}77.69 \\
0.28 \\
13.29 \\
1.68 \\
0.00 \\
0.00 \\
1.08 \\
3.71 \\
2.28 \\
95.03\end{array}$ & $\begin{array}{r}77.54 \\
0.28 \\
12.93 \\
1.78 \\
0.00 \\
0.00 \\
1.02 \\
3.83 \\
2.62 \\
95.93\end{array}$ & $\begin{array}{r}77.71 \\
0.25 \\
13.09 \\
1.76 \\
0.00 \\
0.00 \\
0.99 \\
3.58 \\
2.61 \\
95.94\end{array}$ & $\begin{array}{r}77.66 \\
0.20 \\
13.23 \\
1.87 \\
0.00 \\
0.00 \\
1.03 \\
3.72 \\
2.29 \\
94.55\end{array}$ & $\begin{array}{r}80.42 \\
0.22 \\
11.96 \\
0.95 \\
0.00 \\
0.00 \\
0.96 \\
3.31 \\
2.18 \\
96.74\end{array}$ & $\begin{array}{r}80.25 \\
0.00 \\
12.11 \\
1.09 \\
0.00 \\
0.00 \\
1.03 \\
3.25 \\
2.27 \\
96.54\end{array}$ & $\begin{array}{r}80.74 \\
0.00 \\
11.86 \\
1.01 \\
0.00 \\
0.00 \\
1.10 \\
3.04 \\
2.25 \\
96.64 \\
94.19\end{array}$ & $\begin{array}{r}75.68 \\
0.23 \\
14.09 \\
1.41 \\
0.00 \\
0.00 \\
1.04 \\
4.79 \\
2.75 \\
96.18\end{array}$ \\
\hline
\end{tabular}

\begin{tabular}{|c|c|c|c|c|c|c|c|c|c|c|c|c|c|c|c|c|c|}
\hline $\begin{array}{l}\text { UNE number: } \\
\text { Core, section: } \\
\text { Interval }(\mathrm{cm}):\end{array}$ & $\begin{array}{c}110 \\
34 X-1 \\
68-69\end{array}$ & $\begin{array}{c}111 \\
35 X-2 \\
132-133\end{array}$ & $\begin{array}{c}111 \\
35 X-2 \\
132-133\end{array}$ & $\begin{array}{c}111 \\
35 X-2 \\
132-133\end{array}$ & $\begin{array}{c}111 \\
35 X-2 \\
132-133\end{array}$ & $\begin{array}{c}111 \\
35 X-2 \\
132-133\end{array}$ & $\begin{array}{c}111 \\
35 X-2 \\
132-133\end{array}$ & $\begin{array}{c}111 \\
35 X-2 \\
132-133\end{array}$ & $\begin{array}{c}111 \\
35 X-2 \\
132-133\end{array}$ & $\begin{array}{c}111 \\
35 X-2 \\
132-133\end{array}$ & $\begin{array}{c}112 \\
40 X-4 \\
143-144\end{array}$ & $\begin{array}{c}112 \\
40 X-4 \\
143-144\end{array}$ & $\begin{array}{c}112 \\
40 X-4 \\
143-144\end{array}$ & $\begin{array}{c}112 \\
40 X-4 \\
143-144\end{array}$ & $\begin{array}{c}113 \\
72 X-2 \\
9 \sim 10\end{array}$ & $\begin{array}{c}113 \\
72 \mathrm{X}-2 \\
9 \sim 10\end{array}$ & $\begin{array}{c}113 \\
72 X-2 \\
9 \sim 10\end{array}$ \\
\hline $\mathrm{SiO}_{2}$ & 72.86 & 77.43 & 77.69 & 77.54 & 77.71 & 77.66 & 77.80 & 77.85 & 77.58 & 77.30 & 76.03 & 75.81 & 75.62 & 75.58 & 74.59 & 74.34 & 75.09 \\
\hline $\mathrm{TiO}_{2}$ & 0.43 & 0.21 & 0.28 & 0.28 & 0.25 & 0.20 & 0.26 & 0.27 & 0.22 & 0.22 & 0.45 & 0.30 & 0.38 & 0.49 & 0.00 & 0.22 & 0.00 \\
\hline $\mathrm{Al}_{2} \mathrm{O}_{3}$ & 14.96 & 13.12 & 13.29 & 12.93 & 13.09 & 13.23 & 13.15 & 12.96 & 13.12 & 13.01 & 13.88 & 13.98 & 13.93 & 13.89 & 15.07 & 15.48 & 15.02 \\
\hline $\mathrm{FeO}^{*}$ & 3.34 & 1.74 & 1.68 & 1.78 & 1.76 & 1.87 & 1.72 & 1.67 & 1.77 & 1.96 & 1.94 & 1.84 & 1.89 & 1.95 & 3.04 & 3.09 & 2.75 \\
\hline $\mathrm{MnO}$ & 0.00 & 0.00 & 0.00 & 0.00 & 0.00 & 0.00 & 0.00 & 0.00 & 0.00 & 0.00 & 0.00 & 0.00 & 0.00 & 0.00 & 0.00 & 0.00 & 0.00 \\
\hline $\mathrm{MgO}$ & 0.13 & 0.00 & 0.00 & 0.00 & 0.00 & 0.00 & 0.00 & 0.00 & 0.0 & 0.00 & 0.00 & 0.00 & 0.00 & 0.17 & 0.00 & 0.00 & 0.00 \\
\hline $\mathrm{CaO}$ & 1.86 & 1.04 & 1.08 & 1.02 & 0.99 & 1.03 & 1.11 & 1.05 & 1.1 & 1.08 & 1.57 & 1.70 & 1.66 & 1.56 & 1.14 & 1.16 & 1.06 \\
\hline $\mathrm{K}_{2} \mathrm{O}$ & 2.71 & 3.77 & 3.71 & 3.83 & 3.58 & 3.72 & 3.54 & 3.66 & 3.59 & 3.94 & 2.99 & 2.89 & 2.78 & 2.76 & 3.23 & 2.88 & 3.18 \\
\hline $\mathrm{Na}_{2} \mathrm{O}$ & 3.70 & 2.69 & 2.28 & 2.62 & 2.61 & 2.29 & 2.42 & 2.54 & 2.61 & 2.48 & 3.15 & 3.48 & 3.74 & 3.58 & 2.93 & 2.83 & 2.90 \\
\hline Total & 95.98 & 95.85 & 95.03 & 95.93 & 95.94 & 94.55 & 95.10 & 95.52 & 96.13 & 95.69 & 96.51 & 97.41 & 98.74 & 98.23 & 95.11 & 95.49 & 95.66 \\
\hline
\end{tabular}

\begin{tabular}{lcccrrrr}
\hline UNE number: & 113 & 113 & 114 & 115 & 116 & 116 & 118 \\
Core, section: & $72 \mathrm{X}-2$ & $72 \mathrm{X}-2$ & $75 \mathrm{X}-\mathrm{cc}$ & $75 \mathrm{X}-4$ & $76 \mathrm{X}-2$ & $76 \mathrm{X}-2$ & $78 \mathrm{X}-6$ \\
Interval $(\mathrm{cm}):$ & $9 \sim 10$ & $9 \sim 10$ & $25-25$ & $49-50$ & $55-56$ & $55-56$ & $62-63$ \\
\hline $\mathrm{SiO}_{2}$ & 74.40 & 74.50 & 57.67 & 62.40 & 77.38 & 77.67 & 53.82 \\
$\mathrm{TiO}_{2}$ & 0.14 & 0.25 & 1.19 & 1.07 & 0.15 & 0.00 & 1.00 \\
$\mathrm{Al}_{2} \mathrm{O}_{3}$ & 15.27 & 15.24 & 16.24 & 17.05 & 11.16 & 11.06 & 14.73 \\
$\mathrm{FeO}^{*}$ & 2.95 & 2.83 & 10.06 & 7.15 & 3.96 & 3.56 & 12.70 \\
$\mathrm{MnO}$ & 0.00 & 0.00 & 0.00 & 0.13 & 0.00 & 0.00 & 0.00 \\
$\mathrm{MgO}$ & 0.00 & 0.00 & 3.06 & 0.72 & 0.00 & 0.00 & 4.46 \\
$\mathrm{CaO}$ & 1.23 & 1.23 & 7.62 & 5.64 & 1.84 & 1.95 & 10.12 \\
$\mathrm{~K}_{2} \mathrm{O}$ & 3.21 & 3.07 & 1.26 & 1.76 & 1.68 & 1.74 & 0.71 \\
$\mathrm{Na}_{2} \mathrm{O}$ & 2.80 & 2.88 & 2.91 & 4.09 & 3.83 & 4.02 & 2.45 \\
Total & 96.33 & 97.40 & 98.52 & 98.68 & 99.60 & 96.47 & 96.55 \\
\hline
\end{tabular}


Table 8. Representative analyses of vitric shards from Hole 884B.

\begin{tabular}{|c|c|c|c|c|c|c|c|c|c|c|c|c|c|c|c|c|}
\hline $\begin{array}{l}\text { UNE number: } \\
\text { Core, section: } \\
\text { Interval }(\mathrm{cm}):\end{array}$ & $\begin{array}{c}121 \\
2 \mathrm{H}-2 \\
76-77\end{array}$ & $\begin{array}{c}121 \\
2 \mathrm{H}-2 \\
76-77\end{array}$ & $\begin{array}{c}121 \\
2 \mathrm{H}-2 \\
76-77\end{array}$ & $\begin{array}{c}121 \\
2 \mathrm{H}-2 \\
76-77\end{array}$ & $\begin{array}{c}121 \\
2 \mathrm{H}-2 \\
76-77\end{array}$ & $\begin{array}{c}121 \\
2 \mathrm{H}-2 \\
76-77\end{array}$ & $\begin{array}{c}12 \mathrm{I} \\
2 \mathrm{H}-2 \\
76-77\end{array}$ & $\begin{array}{c}122 \\
2 \mathrm{H}-6 \\
55-56\end{array}$ & $\begin{array}{c}122 \\
2 \mathrm{H}-6 \\
55-56\end{array}$ & $\begin{array}{c}123 \\
2 \mathrm{H}-7 \\
38-39\end{array}$ & $\begin{array}{c}123 \\
2 \mathrm{H}-7 \\
38-39\end{array}$ & $\begin{array}{c}123 \\
2 \mathrm{H}-7 \\
38-39\end{array}$ & $\begin{array}{c}124 \\
3 \mathrm{H}-3 \\
143-144\end{array}$ & $\begin{array}{c}124 \\
3 \mathrm{H}-3 \\
143-144\end{array}$ & $\begin{array}{c}124 \\
3 \mathrm{H}-3 \\
143-144\end{array}$ & $\begin{array}{c}124 \\
3 \mathrm{H}-3 \\
143-144\end{array}$ \\
\hline $\begin{array}{l}\mathrm{SiO}_{2} \\
\mathrm{TiO}_{2} \\
\mathrm{Al}_{2} \mathrm{O}_{3} \\
\mathrm{FeO}^{*} \\
\mathrm{MnO} \\
\mathrm{MgO} \\
\mathrm{CaO} \\
\mathrm{K}_{2} \mathrm{O} \\
\mathrm{Na}_{2} \mathrm{O} \\
\mathrm{Total}\end{array}$ & $\begin{array}{c}72.7 \\
0.57 \\
15.16 \\
2.61 \\
0 \\
0.17 \\
1.75 \\
3.35 \\
3.69 \\
97\end{array}$ & $\begin{array}{l}75 \\
0.4 \\
14.4 \\
1.79 \\
0 \\
0 \\
0.78 \\
4.04 \\
3.6 \\
97.5\end{array}$ & $\begin{array}{r}74.07 \\
0.43 \\
15.18 \\
2.11 \\
0 \\
0 \\
1.34 \\
3.82 \\
3.06 \\
95.29\end{array}$ & $\begin{array}{c}74.4 \\
0.36 \\
15.13 \\
1.97 \\
0 \\
0 \\
1.35 \\
3.45 \\
3.34 \\
95.74\end{array}$ & $\begin{array}{c}73.7 \\
0.49 \\
15.18 \\
2.19 \\
0 \\
0 \\
1.38 \\
3.47 \\
3.59 \\
96.74\end{array}$ & $\begin{array}{r}74.23 \\
0.46 \\
14.96 \\
2.05 \\
0 \\
0 \\
1.26 \\
3.69 \\
3.35 \\
96.78\end{array}$ & $\begin{array}{r}69.26 \\
0.85 \\
15.87 \\
3.87 \\
0 \\
0.66 \\
3.17 \\
2.77 \\
3.57 \\
98.99\end{array}$ & $\begin{array}{c}74.73 \\
0.39 \\
13.62 \\
2.75 \\
0 \\
0 \\
1.71 \\
2.23 \\
4.57 \\
97.19\end{array}$ & $\begin{array}{c}74.81 \\
0.14 \\
13.72 \\
2.76 \\
0 \\
0 \\
1.77 \\
2.23 \\
4.57 \\
97.05\end{array}$ & $\begin{array}{c}74.25 \\
0.34 \\
14.03 \\
1.98 \\
0 \\
0 \\
0.44 \\
4.66 \\
4.3 \\
97.5\end{array}$ & $\begin{array}{c}71.77 \\
0.31 \\
16.49 \\
0.97 \\
0 \\
0 \\
1.91 \\
3.21 \\
5.34 \\
97.83\end{array}$ & $\begin{array}{c}70.44 \\
0.63 \\
15.77 \\
2.6 \\
0 \\
0.19 \\
2.41 \\
3.15 \\
4.81 \\
97.92\end{array}$ & $\begin{array}{r}70.29 \\
0.65 \\
15.99 \\
3.03 \\
0 \\
0.3 \\
2.32 \\
3.4 \\
4.02 \\
97.77\end{array}$ & $\begin{array}{r}71.63 \\
0.59 \\
15.46 \\
2.38 \\
0 \\
0.25 \\
1.81 \\
3.75 \\
4.13 \\
98.19\end{array}$ & $\begin{array}{l}71.8 \\
1.13 \\
13.76 \\
3.81 \\
0 \\
0 \\
1.46 \\
4.73 \\
3.3 \\
97\end{array}$ & $\begin{array}{r}70.86 \\
0.64 \\
15.88 \\
2.82 \\
0 \\
0.38 \\
2.23 \\
3.82 \\
3.37 \\
96.27\end{array}$ \\
\hline $\begin{array}{l}\text { UNE number: } \\
\text { Core, section: } \\
\text { Interval }(\mathrm{cm}) \text { : }\end{array}$ & $\begin{array}{c}124 \\
3 \mathrm{H}-3 \\
143-144 \\
\end{array}$ & $\begin{array}{c}124 \\
3 \mathrm{H}-3 \\
143-144 \\
\end{array}$ & $\begin{array}{c}125 \\
4 \mathrm{H}-2 \\
119-120 \\
\end{array}$ & $\begin{array}{c}125 \\
4 \mathrm{H}-2 \\
119-120 \\
\end{array}$ & $\begin{array}{c}125 \\
4 \mathrm{H}-2 \\
119-120 \\
\end{array}$ & $\begin{array}{c}125 \\
4 \mathrm{H}-2 \\
119-120 \\
\end{array}$ & $\begin{array}{c}125 \\
4 \mathrm{H}-2 \\
119-120 \\
\end{array}$ & $\begin{array}{c}125 \\
4 \mathrm{H}-2 \\
119-120 \\
\end{array}$ & $\begin{array}{c}125 \\
4 \mathrm{H}-2 \\
119-120 \\
\end{array}$ & $\begin{array}{c}126 \\
4 \mathrm{H}-2 \\
141-142 \\
\end{array}$ & $\begin{array}{c}127 \\
4 \mathrm{H}-4 \\
17-18 \\
\end{array}$ & $\begin{array}{c}127 \\
4 \mathrm{H}-4 \\
17-18 \\
\end{array}$ & $\begin{array}{c}127 \\
4 \mathrm{H}-04 \\
17-18 \\
\end{array}$ & $\begin{array}{c}127 \\
4 \mathrm{H}-04 \\
17-18 \\
\end{array}$ & $\begin{array}{c}128 \\
5 \mathrm{H}-03 \\
38-39 \\
\end{array}$ & $\begin{array}{c}128 \\
5 \mathrm{H}-03 \\
38-39 \\
\end{array}$ \\
\hline $\begin{array}{l}\mathrm{SiO}_{2} \\
\mathrm{TiO}_{2} \\
\mathrm{Al}_{2} \mathrm{O}_{3} \\
\mathrm{FeO}^{*} \\
\mathrm{MnO} \\
\mathrm{MgO} \\
\mathrm{CaO} \\
\mathrm{K}_{2} \mathrm{O} \\
\mathrm{Na}_{2} \mathrm{O} \\
\mathrm{Total}\end{array}$ & $\begin{array}{r}72.03 \\
0.45 \\
15.37 \\
2.24 \\
0 \\
0.15 \\
1.62 \\
3.78 \\
4.36 \\
98.78\end{array}$ & $\begin{array}{c}70.6 \\
0.69 \\
15.66 \\
2.77 \\
0 \\
0.42 \\
2.2 \\
3.76 \\
3.9 \\
97.75\end{array}$ & $\begin{array}{c}79.54 \\
0 \\
12.79 \\
1.28 \\
0 \\
0 \\
1.55 \\
1.75 \\
3.09 \\
97.69\end{array}$ & $\begin{array}{r}79.15 \\
0.13 \\
13.05 \\
1.44 \\
0 \\
0 \\
1.61 \\
1.73 \\
2.89 \\
98.19\end{array}$ & $\begin{array}{c}79.85 \\
0 \\
12.84 \\
1.41 \\
0 \\
0 \\
1.57 \\
1.71 \\
2.64 \\
96.93\end{array}$ & $\begin{array}{c}79.62 \\
0.2 \\
13.02 \\
1.37 \\
0 \\
0 \\
1.62 \\
1.71 \\
2.46 \\
97.97\end{array}$ & $\begin{array}{c}80.08 \\
0.16 \\
12.83 \\
1.52 \\
0 \\
0 \\
1.58 \\
1.66 \\
2.17 \\
97.44\end{array}$ & $\begin{array}{c}80.36 \\
0 \\
12.85 \\
1.36 \\
0 \\
0 \\
1.66 \\
1.62 \\
2.16 \\
96.71\end{array}$ & $\begin{array}{c}81.08 \\
0 \\
12.16 \\
1.22 \\
0 \\
0 \\
1.3 \\
1.9 \\
2.35 \\
97.4\end{array}$ & $\begin{array}{c}64.16 \\
1 \\
15.7 \\
6.57 \\
0 \\
1.44 \\
5.45 \\
1.79 \\
3.89 \\
102.53\end{array}$ & $\begin{array}{c}76.05 \\
0.36 \\
13.56 \\
2.48 \\
0 \\
0 \\
1.97 \\
2.08 \\
3.5 \\
95.48\end{array}$ & $\begin{array}{c}67.5 \\
0.91 \\
15.18 \\
5.24 \\
0 \\
1.32 \\
4.32 \\
1.56 \\
3.96 \\
100.38\end{array}$ & $\begin{array}{c}76.41 \\
0.43 \\
13.53 \\
2.38 \\
0 \\
0 \\
1.64 \\
2.09 \\
3.52 \\
96.2\end{array}$ & $\begin{array}{r}76.65 \\
0.45 \\
13.34 \\
2.57 \\
0 \\
0 \\
1.69 \\
2.05 \\
3.25 \\
96.34\end{array}$ & $\begin{array}{r}58.51 \\
1.05 \\
18.16 \\
6.53 \\
0 \\
2.34 \\
8.31 \\
0.86 \\
4.24 \\
95.04\end{array}$ & $\begin{array}{c}72.04 \\
0.65 \\
14.77 \\
3.41 \\
0 \\
0.27 \\
2.52 \\
2.14 \\
4.2 \\
98.9\end{array}$ \\
\hline $\begin{array}{l}\text { UNE number: } \\
\text { Core, section: } \\
\text { Interval }(\mathrm{cm}):\end{array}$ & $\begin{array}{c}128 \\
5 \mathrm{H}-03 \\
38-39 \\
\end{array}$ & $\begin{array}{c}129 \\
5 \mathrm{H}-04 \\
120-121 \\
\end{array}$ & $\begin{array}{c}129 \\
5 \mathrm{H}-04 \\
120-121 \\
\end{array}$ & $\begin{array}{c}129 \\
5 \mathrm{H}-04 \\
120-121 \\
\end{array}$ & $\begin{array}{c}129 \\
5 \mathrm{H}-4 \\
120-121 \\
\end{array}$ & $\begin{array}{c}130 \\
6 \mathrm{H}-2 \\
120-121 \\
\end{array}$ & $\begin{array}{c}130 \\
6 \mathrm{H}-2 \\
120-121 \\
\end{array}$ & $\begin{array}{c}130 \\
6 \mathrm{H}-2 \\
120-121 \\
\end{array}$ & $\begin{array}{c}130 \\
6 \mathrm{H}-2 \\
120-121 \\
\end{array}$ & $\begin{array}{c}130 \\
6 \mathrm{H}-2 \\
120-121 \\
\end{array}$ & $\begin{array}{c}130 \\
6 \mathrm{H}-2 \\
120-121 \\
\end{array}$ & $\begin{array}{c}130 \\
6 \mathrm{H}-2 \\
120-121 \\
\end{array}$ & $\begin{array}{c}131 \\
6 \mathrm{H}-7 \\
22-23\end{array}$ & $\begin{array}{c}131 \\
6 \mathrm{H}-7 \\
22-23 \\
\end{array}$ & $\begin{array}{c}132 \\
7 \mathrm{H}-2 \\
115-116 \\
\end{array}$ & $\begin{array}{c}132 \\
7 \mathrm{H}-2 \\
115-116 \\
\end{array}$ \\
\hline $\begin{array}{l}\mathrm{SiO}_{2} \\
\mathrm{TiO}_{2} \\
\mathrm{Al}_{2} \mathrm{O}_{3} \\
\mathrm{FeO} \\
\mathrm{MnO} \\
\mathrm{MgO} \\
\mathrm{CaO} \\
\mathrm{K}_{2} \mathrm{O} \\
\mathrm{Na}_{2} \mathrm{O} \\
\text { Total }\end{array}$ & $\begin{array}{c}76.11 \\
0.15 \\
13.77 \\
2.04 \\
0 \\
0 \\
1.36 \\
2.71 \\
3.86 \\
97.36\end{array}$ & $\begin{array}{c}75.3 \\
0.58 \\
14.52 \\
3.09 \\
0 \\
0 \\
1.87 \\
2.15 \\
2.49 \\
96.25\end{array}$ & $\begin{array}{r}75.96 \\
0.41 \\
14.15 \\
3.13 \\
0 \\
0 \\
1.73 \\
2.21 \\
2.41 \\
96.25\end{array}$ & $\begin{array}{c}75.93 \\
0.53 \\
14 \\
3.03 \\
0 \\
0 \\
1.74 \\
2.17 \\
2.6 \\
95.39\end{array}$ & $\begin{array}{c}74.68 \\
0.49 \\
14.24 \\
3.26 \\
0 \\
0 \\
1.88 \\
2.19 \\
3.26 \\
98.47\end{array}$ & $\begin{array}{l}78.3 \\
0.32 \\
12.35 \\
1.32 \\
0 \\
0 \\
0.77 \\
3.07 \\
3.87 \\
99.97\end{array}$ & $\begin{array}{c}78.3 \\
0.32 \\
12.35 \\
1.32 \\
0 \\
0 \\
0.77 \\
3.07 \\
3.87 \\
99.97\end{array}$ & $\begin{array}{c}78.72 \\
0.16 \\
12.24 \\
1.33 \\
0 \\
0 \\
0.8 \\
2.98 \\
3.76 \\
100.82\end{array}$ & $\begin{array}{c}79.71 \\
0.19 \\
12.34 \\
1.5 \\
0 \\
0 \\
0.82 \\
2.83 \\
2.61 \\
95.8\end{array}$ & $\begin{array}{c}79.34 \\
0.27 \\
12.39 \\
1.55 \\
0 \\
0 \\
0.89 \\
2.94 \\
2.62 \\
95.82\end{array}$ & $\begin{array}{c}79.92 \\
0.15 \\
12.43 \\
1.34 \\
0 \\
0 \\
0.74 \\
2.9 \\
2.51 \\
95.26\end{array}$ & $\begin{array}{c}80.4 \\
0.13 \\
12.35 \\
1.34 \\
0 \\
0 \\
0.78 \\
2.75 \\
2.25 \\
94.86\end{array}$ & $\begin{array}{r}69.4 \\
0.65 \\
14.56 \\
5.22 \\
0 \\
0.81 \\
3.66 \\
1.42 \\
4.28 \\
94.63\end{array}$ & $\begin{array}{r}73.47 \\
0.14 \\
16.26 \\
0.61 \\
0 \\
0 \\
3.66 \\
0.44 \\
5.41 \\
102.77\end{array}$ & $\begin{array}{c}74.43 \\
0.42 \\
14.05 \\
2.3 \\
0 \\
0 \\
1.73 \\
3.38 \\
3.69 \\
99.12\end{array}$ & $\begin{array}{c}77.45 \\
0 \\
13.36 \\
1.46 \\
0 \\
0 \\
0.64 \\
3.74 \\
3.36 \\
96.8\end{array}$ \\
\hline $\begin{array}{l}\text { UNE number: } \\
\text { Core, section: } \\
\text { Interval }(\mathrm{cm}) \text { : }\end{array}$ & $\begin{array}{c}132 \\
7 \mathrm{H}-2 \\
115-116 \\
\end{array}$ & $\begin{array}{c}132 \\
7 \mathrm{H}-2 \\
115-116 \\
\end{array}$ & $\begin{array}{c}134 \\
8 \mathrm{H}-5 \\
89-90 \\
\end{array}$ & $\begin{array}{c}135 \\
9 \mathrm{H}-7 \\
2 \sim 3 \\
\end{array}$ & $\begin{array}{c}135 \\
9 \mathrm{H}-7 \\
2-3\end{array}$ & $\begin{array}{c}135 \\
9 \mathrm{H}-7 \\
2 \sim 3 \\
\end{array}$ & $\begin{array}{c}135 \\
9 \mathrm{H}-7 \\
2-3\end{array}$ & $\begin{array}{c}136 \\
13 X-1 \\
32-33 \\
\end{array}$ & $\begin{array}{c}136 \\
13 X-1 \\
32-33\end{array}$ & $\begin{array}{l}136 \\
13 X-1 \\
32-33\end{array}$ & $\begin{array}{c}136 \\
13 X-1 \\
32-33\end{array}$ & $\begin{array}{c}136 \\
13 X-1 \\
32-33 \\
\end{array}$ & $\begin{array}{c}136 \\
13 X-1 \\
32-33 \\
\end{array}$ & $\begin{array}{c}136 \\
13 X-1 \\
32-33\end{array}$ & $\begin{array}{c}136 \\
13 X-1 \\
32-33 \\
\end{array}$ & $\begin{array}{c}136 \\
13 X-1 \\
32-33 \\
\end{array}$ \\
\hline $\begin{array}{l}\mathrm{SiO}_{2} \\
\mathrm{TiO}_{2} \\
\mathrm{Al}_{2} \mathrm{O}_{3} \\
\mathrm{FeO}^{*} \\
\mathrm{MnO} \\
\mathrm{MgO} \\
\mathrm{CaO} \\
\mathrm{K}_{2} \mathrm{O} \\
\mathrm{Na}_{2} \mathrm{O} \\
\text { Total }\end{array}$ & $\begin{array}{c}74.3 \\
0.51 \\
14.02 \\
2.27 \\
0 \\
0.21 \\
2.09 \\
2.92 \\
3.69 \\
97.4\end{array}$ & $\begin{array}{r}74.34 \\
0.54 \\
14.39 \\
2.53 \\
0 \\
0 \\
1.95 \\
2.81 \\
3.44 \\
96.86\end{array}$ & $\begin{array}{r}56.8 \\
1.33 \\
18.72 \\
8.31 \\
0 \\
1.59 \\
8.09 \\
1.08 \\
4.07 \\
104.95\end{array}$ & $\begin{array}{c}73.59 \\
0.59 \\
14 \\
2.74 \\
0 \\
0.18 \\
2.39 \\
2.4 \\
4.1 \\
99.98\end{array}$ & $\begin{array}{c}79.27 \\
0 \\
12.28 \\
0.73 \\
0 \\
0 \\
0.36 \\
3.83 \\
3.53 \\
98.96\end{array}$ & $\begin{array}{r}75.15 \\
0.51 \\
13.44 \\
2.37 \\
0 \\
0 \\
2.07 \\
2.46 \\
4.01 \\
99.86\end{array}$ & $\begin{array}{r}74.59 \\
0.44 \\
13.63 \\
2.54 \\
0 \\
0.13 \\
2.17 \\
2.56 \\
3.94 \\
98.26\end{array}$ & $\begin{array}{l}79.5 \\
0 \\
12.16 \\
0.9 \\
0 \\
0 \\
0.9 \\
2.59 \\
3.95 \\
97.17\end{array}$ & $\begin{array}{c}79.73 \\
0 \\
12.1 \\
1.09 \\
0 \\
0 \\
0.98 \\
2.3 \\
3.81 \\
95.2\end{array}$ & $\begin{array}{c}79.33 \\
0 \\
12.31 \\
0.93 \\
0 \\
0 \\
0.96 \\
2.46 \\
4.01 \\
96.14\end{array}$ & $\begin{array}{l}79.7 \\
0 \\
12.07 \\
0.84 \\
0 \\
0 \\
0.94 \\
2.53 \\
3.91 \\
97.12\end{array}$ & $\begin{array}{c}79.66 \\
0 \\
12.12 \\
1.02 \\
0 \\
0 \\
0.86 \\
2.51 \\
3.82 \\
96.9\end{array}$ & $\begin{array}{c}79.66 \\
0 \\
12.12 \\
1.02 \\
0 \\
0 \\
0.86 \\
2.51 \\
3.82 \\
96.9\end{array}$ & $\begin{array}{c}79.3 \\
0 \\
12.49 \\
1.01 \\
0 \\
0 \\
0.88 \\
2.38 \\
3.94 \\
96.07\end{array}$ & $\begin{array}{c}79.16 \\
0 \\
12.2 \\
1.02 \\
0 \\
0 \\
0.91 \\
2.62 \\
4.1 \\
97.78\end{array}$ & $\begin{array}{c}79.71 \\
0 \\
12.19 \\
0.86 \\
0 \\
0 \\
0.93 \\
2.46 \\
3.86 \\
95.95\end{array}$ \\
\hline
\end{tabular}


Table 8 (continued).

\begin{tabular}{|c|c|c|c|c|c|c|c|c|c|c|}
\hline $\begin{array}{l}\text { UNE number: } \\
\text { Core, section: } \\
\text { Interval }(\mathrm{cm}) \text { : }\end{array}$ & $\begin{array}{c}137 \\
14 X-2 \\
143-144 \\
\end{array}$ & $\begin{array}{c}137 \\
14 X-2 \\
143-144 \\
\end{array}$ & $\begin{array}{c}137 \\
14 X-2 \\
143-144 \\
\end{array}$ & $\begin{array}{c}137 \\
14 X-2 \\
143-144 \\
\end{array}$ & $\begin{array}{c}137 \\
14 X-2 \\
143-144\end{array}$ & $\begin{array}{c}138 \\
16 X-1 \\
141-142 \\
\end{array}$ & $\begin{array}{c}138 \\
16 X-1 \\
141-142 \\
\end{array}$ & $\begin{array}{c}138 \\
16 X-1 \\
141-142 \\
\end{array}$ & $\begin{array}{c}139 \\
16 \mathrm{X}-2 \\
116-117 \\
\end{array}$ & $\begin{array}{c}139 \\
16 \times-2 \\
116-117 \\
\end{array}$ \\
\hline $\begin{array}{l}\mathrm{SiO}_{2} \\
\mathrm{TiO}_{2} \\
\mathrm{Al}_{2} \mathrm{O}_{3} \\
\mathrm{FeO}^{*} \\
\mathrm{MnO} \\
\mathrm{MgO} \\
\mathrm{CaO} \\
\mathrm{K}_{2} \mathrm{O} \\
\mathrm{Na}_{2} \mathrm{O} \\
\mathrm{Total}\end{array}$ & $\begin{array}{c}74.91 \\
0.28 \\
13.97 \\
1.92 \\
0 \\
0 \\
1.49 \\
2.93 \\
4.51 \\
96.33\end{array}$ & $\begin{array}{c}74.43 \\
0.46 \\
13.83 \\
1.9 \\
0 \\
0 \\
1.53 \\
2.93 \\
4.92 \\
97.22\end{array}$ & $\begin{array}{c}75.01 \\
0.42 \\
13.77 \\
1.96 \\
0 \\
0 \\
1.48 \\
2.8 \\
4.57 \\
96.96\end{array}$ & $\begin{array}{r}75.15 \\
0.38 \\
13.73 \\
1.67 \\
0 \\
0 \\
1.49 \\
2.85 \\
4.73 \\
96.56\end{array}$ & $\begin{array}{c}74.86 \\
0.41 \\
13.9 \\
1.91 \\
0 \\
0 \\
1.5 \\
2.85 \\
4.57 \\
97.35\end{array}$ & $\begin{array}{c}73.88 \\
0.4 \\
13.11 \\
3.99 \\
0 \\
0 \\
2.44 \\
1.95 \\
4.23 \\
96.7\end{array}$ & $\begin{array}{c}73.43 \\
0.41 \\
13.27 \\
4.24 \\
0 \\
0 \\
2.71 \\
2.06 \\
3.87 \\
96.64\end{array}$ & $\begin{array}{c}73.56 \\
0.42 \\
13.06 \\
4.2 \\
0 \\
0 \\
2.56 \\
1.97 \\
4.24 \\
96.5\end{array}$ & $\begin{array}{r}65.01 \\
0.74 \\
16.46 \\
5.36 \\
0 \\
0.66 \\
2.93 \\
4.69 \\
4.14 \\
99.24\end{array}$ & $\begin{array}{r}65.02 \\
0.61 \\
16.22 \\
5.46 \\
0 \\
0.53 \\
3.13 \\
4.72 \\
4.32 \\
97.05\end{array}$ \\
\hline $\begin{array}{l}\text { UNE number: } \\
\text { Core, section: } \\
\text { Interval }(\mathrm{cm}) \text { : }\end{array}$ & $\begin{array}{c}139 \\
16 X-2 \\
116-117\end{array}$ & $\begin{array}{c}139 \\
16 X-2 \\
116-117\end{array}$ & $\begin{array}{c}139 \\
16 X-2 \\
116-117\end{array}$ & $\begin{array}{c}139 \\
16 X-2 \\
116-117\end{array}$ & $\begin{array}{c}140 \\
23 X-1 \\
142-143\end{array}$ & $\begin{array}{c}141 \\
23 X-3 \\
30-31\end{array}$ & $\begin{array}{c}142 \\
23 X-5 \\
37-38\end{array}$ & $\begin{array}{c}142 \\
23 X-5 \\
37-38\end{array}$ & $\begin{array}{c}142 \\
23 X-5 \\
37-38\end{array}$ & $\begin{array}{c}142 \\
23 X-5 \\
37-38 \\
\end{array}$ \\
\hline $\begin{array}{l}\mathrm{SiO}_{2} \\
\mathrm{TiO}_{2} \\
\mathrm{Al}_{2} \mathrm{O}_{3} \\
\mathrm{FeO}^{*} \\
\mathrm{MnO} \\
\mathrm{MgO} \\
\mathrm{CaO} \\
\mathrm{K}_{2} \mathrm{O} \\
\mathrm{Na}_{2} \mathrm{O} \\
\text { Total }\end{array}$ & $\begin{array}{c}63.98 \\
0.71 \\
16.56 \\
5.37 \\
0 \\
0.75 \\
3.52 \\
4.64 \\
4.47 \\
98.07\end{array}$ & $\begin{array}{r}64.09 \\
0.79 \\
16.52 \\
5.55 \\
0 \\
0.78 \\
3.18 \\
4.72 \\
4.37 \\
98.25\end{array}$ & $\begin{array}{r}65.46 \\
0.64 \\
16.29 \\
5.09 \\
0 \\
0.62 \\
2.93 \\
4.85 \\
4.12 \\
98.04\end{array}$ & $\begin{array}{c}65.25 \\
0.66 \\
16.46 \\
5.38 \\
0 \\
0.65 \\
3.07 \\
4.67 \\
3.86 \\
96.1\end{array}$ & $\begin{array}{c}54.27 \\
1.055 \\
17.01 \\
10.88 \\
0 \\
3.52 \\
8.52 \\
0.92 \\
3.33 \\
101.37\end{array}$ & $\begin{array}{c}62.91 \\
1.17 \\
15.52 \\
7.59 \\
0 \\
1.46 \\
5.22 \\
1.68 \\
4.45 \\
99.27\end{array}$ & $\begin{array}{c}78.8 \\
0 \\
12.48 \\
0.3 \\
0 \\
0 \\
0.39 \\
4.55 \\
3.49 \\
96.49\end{array}$ & $\begin{array}{c}79.04 \\
0 \\
12.41 \\
0.37 \\
0 \\
0 \\
0.48 \\
4.55 \\
3.14 \\
98.87\end{array}$ & $\begin{array}{c}79.02 \\
0 \\
12.43 \\
0.23 \\
0 \\
0 \\
0.39 \\
4.81 \\
3.11 \\
98.47\end{array}$ & $\begin{array}{c}78.87 \\
0 \\
12.61 \\
0.26 \\
0 \\
0 \\
0.46 \\
4.51 \\
3.3 \\
98.08\end{array}$ \\
\hline
\end{tabular}

Notes: Major elements reported as wt\% oxides. UNE number refers to the ash layer number analyzed at UNE (see Table 4). Total is the original analytical total. Individual oxide values sum to 100\%. Zero values indicate the element abundances are less than the detection limit of EDS. All Fe reported as FeO*. 


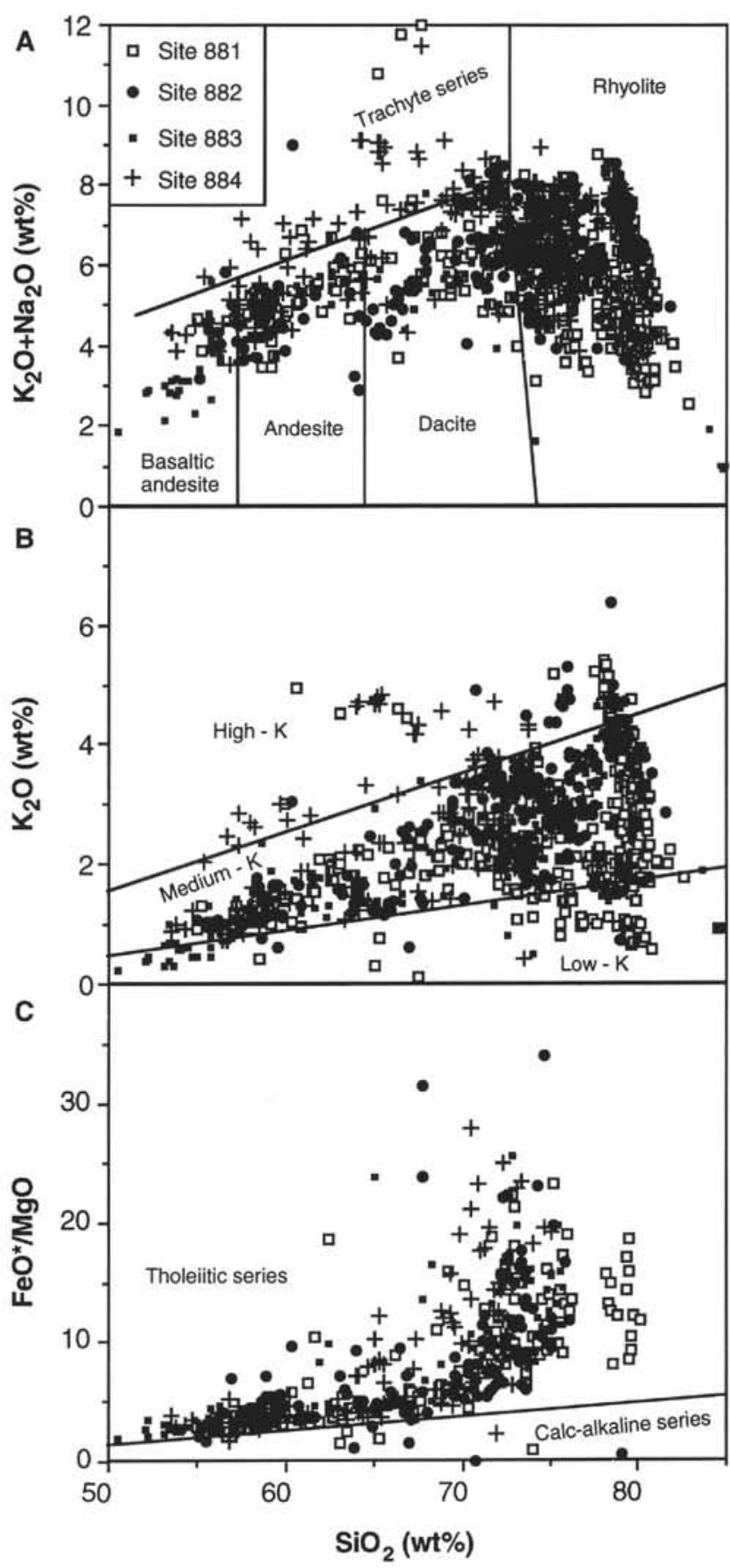

Figure 4. A. Variation of $w \mathrm{t} \% \mathrm{~K}_{2} \mathrm{O}+\mathrm{Na}_{2} \mathrm{O}$ vs. $\mathrm{SiO}_{2}$ for ashes from Sites 881-884. B. Variation of wt $\% \mathrm{~K}_{2} \mathrm{O}$ vs. $\mathrm{SiO}_{2}$ for ashes from Sites 881-884. C. Variation of $\mathrm{FeO} * / \mathrm{MgO}$ vs. wt $\% \mathrm{SiO}_{2}$ for ashes from Sites $881-884$.

(Pearce and Parkinson, 1993). But our primary conclusion at this stage is that we cannot detect any evidence for crustal thickening from the major element compositions of the Leg 145 ashes.

Whether some level of global synchroneity of explosive volcanism exists and whether such pulses could be climatically significant (Kennett and Thunell, 1977; Ninkovich and Donn, 1976; Kennett et al., 1977) have been controversial issues. Excluding localized effects such as the subduction of adjacent backarc basins in the Philippine region for example, Cambray (1991) advocated synchroneity of explosive activity on the basis of a comprehensive analysis of the principal arcs bordering the Pacific plate. His analysis involved systematic frequency/thickness ash layer determinations, and discrimination

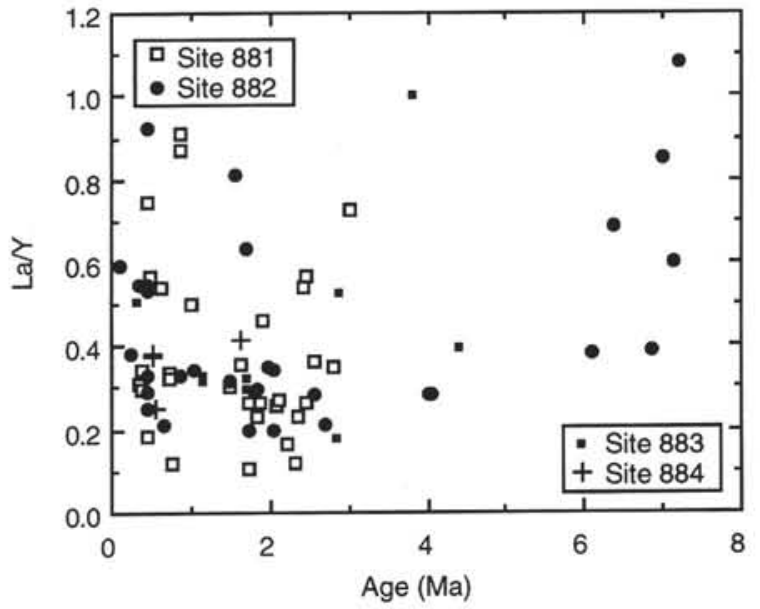

Figure 5. Variation of $\mathrm{La} / \mathrm{Y}$ as a function of age for the ash layers from Sites 881-884.

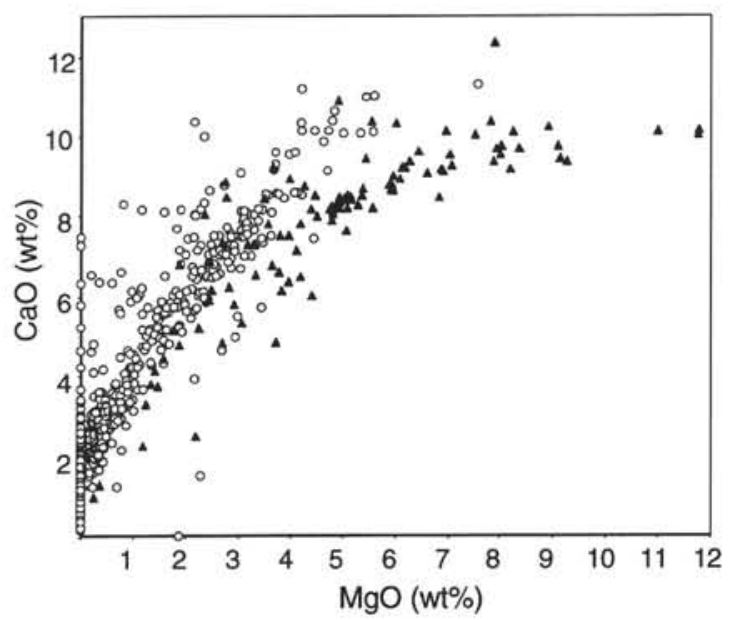

Figure 6. Variation of $\mathrm{wt} \% \mathrm{CaO}$ vs. $\mathrm{MgO}$ for ashes from Sites 881-884 (open circles) compared with lavas from the Central Kamchatka Depression and East Kamchatka (solid triangles).

between adjacent arc and remote inputs. Two marked periods emerge of concentrated explosive activity in arcs emerge: (1) lower to middle Miocene (18-13 Ma) and (2) Pliocene-Quaternary (5 Ma-present).

There is no evidence from Leg 145 to substantiate the Miocene pulse, but there is ample evidence to support the claim of increased explosivity in the younger period. We note an increase in volcanism derived from the Aleutian arc at $\sim 5 \mathrm{Ma}$ is also documented at Leg 145 Site 887 , with a further increase in intensity at $\sim 2.6 \mathrm{Ma}$ (Cao et al., this volume). The nature of a Pacific plate-wide trigger for these enhanced periods of explosive activity is clearly a matter of prime cross-disciplinary research interest, not the least because of the possible climatic effects.

An important point previously made by Scheidegger et al. (1980) is the contrasts in compositional modes between the rhyolite-dominated ashes and the predominance of basalt in Kamchatka (Leonova, 1979; Fedotov and Masurenkov, 1991). Although individual arc volcanoes such as Fuji and Klyuchevskoy are dominated overwhelmingly by basalt with a large fraction of pyroclastic rock, it is nevertheless common knowledge that far-travelled ash clouds from plinian explosive eruptions are more likely to be composed of rhyolite.

Paleogene volcanism has previously been recognized at a number of central Pacific basins (Rea and Thiede, 1981) and the Hess Rise (Vallier et al., 1983). We suggest an island arc source for the Eocene- 


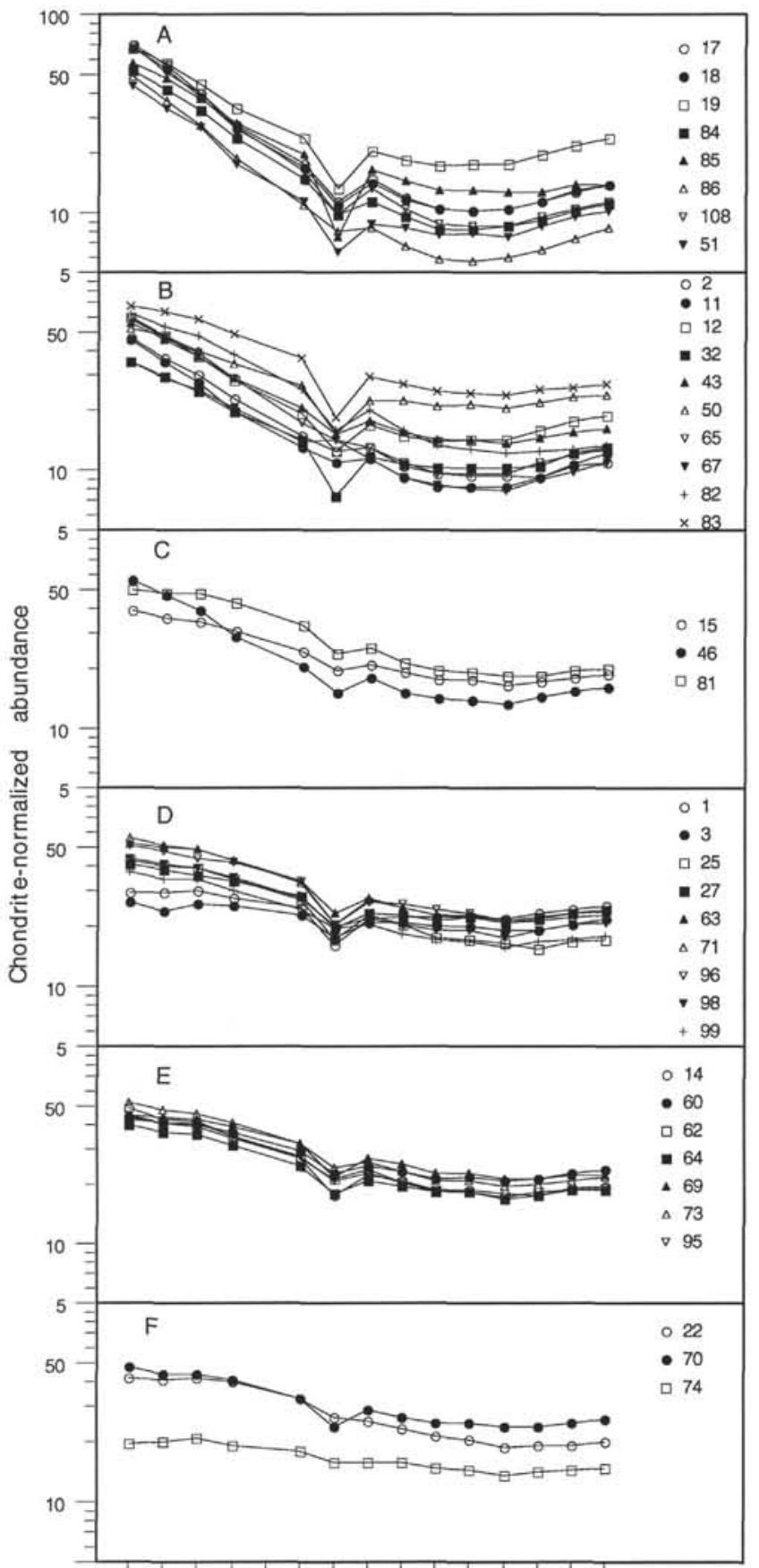

La ce Pr Nd Sm Eu Gd Tb Dy Ho Er Tm Yb Lu

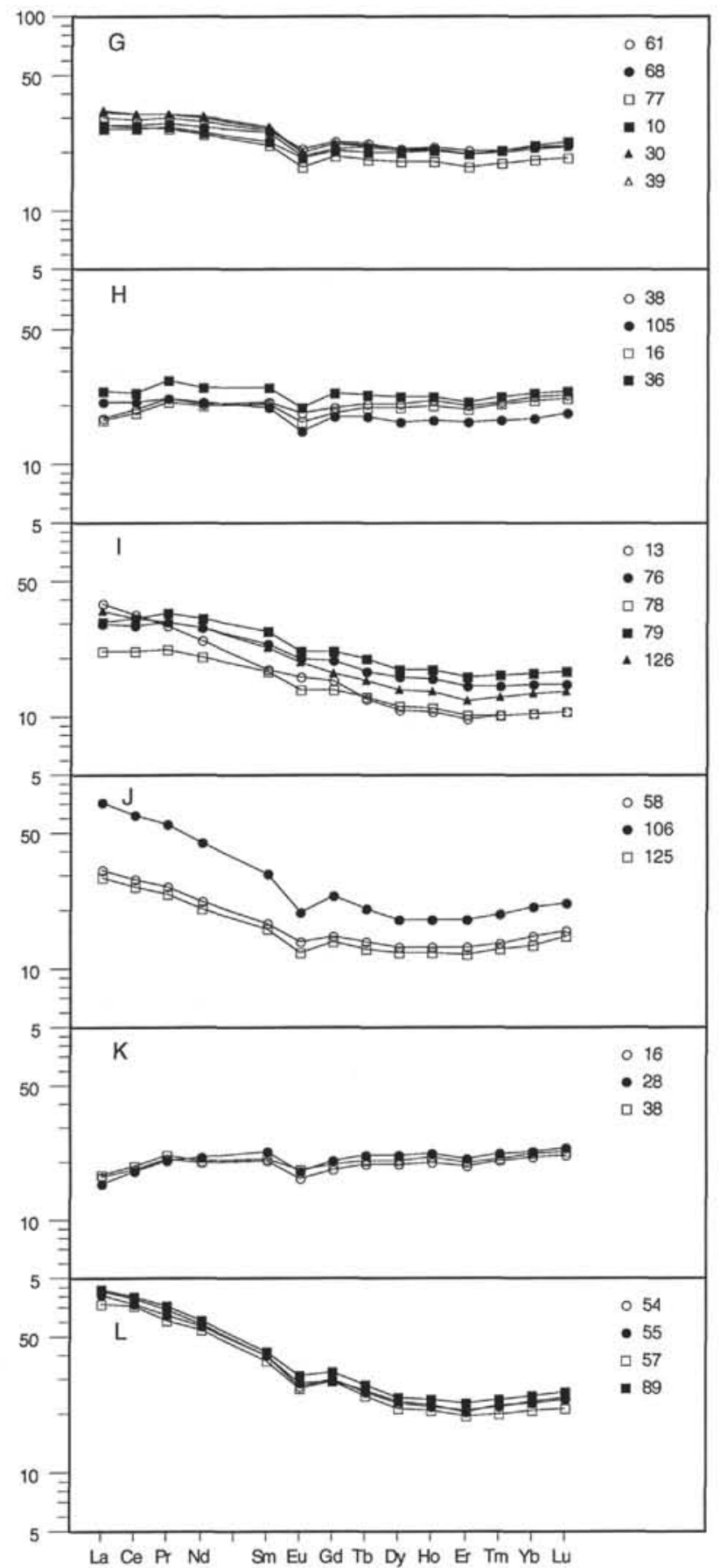

La Ce Pr Nd Sm Eu Gd To Dy Ho Er Tm Yb Lu

Figure 7. Chondrite-normalized rare earth element abundances for different groups (A-L) of ashes. Numbers by the symbols for each pattern are the UNE layer numbers. Normalizing values from Sun and McDonough (1989).

Oligocene ashes recovered from the Detroit Seamount Sites, which would have been located $\sim 30^{\circ}-40^{\circ} \mathrm{N}$ at that time, and possibly downwind from early Aleutian arc activity (Rea and Duncan, 1986; Lonsdale, 1988).

\section{CONCLUSIONS}

1. A Late Miocene increase in explosive activity of the KurileKamchatka arc is apparent $(<6.3 \mathrm{Ma})$ from the number and thickness of ash deposits recovered from Sites $881,882,883$, and 884. A further major increase of activity occurred at $2.6 \mathrm{Ma}$ lasted to the present. A number of spectacularly thick $(\sim 30-250 \mathrm{~cm})$ Pliocene-Pleistocene rhyolitic layers are present that appear to be plinian airfall, and must represent colossal eruptions.

2. A spectrum of compositions of both major and trace elements in these ashes ranges from basaltic andesite to rhyolite, from lowthrough medium- to high-K series, and with strongly contrasted trace element abundance patterns. We believe these reflect different source origins that may well prove to be derived from the known distinct volcanic belts in the Kurile-Kamchatka system.

3. Near coincidence of the true liquid compositions (vitric shards) with experimentally determined low-pressure crystal-melt cotectics reflects the significant role of fractional crystallization in the evolution of mafic-to-felsic systems. Coincidence of $\mathrm{Sr}$ and $\mathrm{Nd}$ isotopic charac- 
Table 9. Bulk major element and trace element analyses and $\mathrm{Sr}$-Nd isotopic ratios of ash layers from Site 881.

\begin{tabular}{|c|c|c|c|c|c|c|c|c|c|c|c|c|c|c|c|c|c|}
\hline $\begin{array}{l}\text { Hole: } \\
\text { UNE number: } \\
\text { Core, section: } \\
\text { Interval (cm): }\end{array}$ & $\begin{array}{c}881 \mathrm{~A} \\
1 \\
1 \mathrm{H}-02 \\
116-117\end{array}$ & $\begin{array}{c}881 \mathrm{~A} \\
2 \\
1 \mathrm{H}-04 \\
44-45\end{array}$ & $\begin{array}{c}881 \mathrm{~A} \\
3 \\
1 \mathrm{H}-06 \\
52-53\end{array}$ & $\begin{array}{c}881 \mathrm{~A} \\
4 \\
1 \mathrm{H}-06 \\
109-110 \\
\end{array}$ & $\begin{array}{c}881 \mathrm{~B} \\
7 \\
2 \mathrm{H}-05 \\
149-150\end{array}$ & $\begin{array}{c}881 \mathrm{~B} \\
8 \\
3 \mathrm{H}-01 \\
2-3\end{array}$ & $\begin{array}{c}881 \mathrm{~B} \\
9 \\
3 \mathrm{H}-01 \\
35-36\end{array}$ & $\begin{array}{c}881 \mathrm{~B} \\
10 \\
3 \mathrm{H}-05 \\
19-20\end{array}$ & $\begin{array}{c}881 \mathrm{~B} \\
12 \\
4 \mathrm{H}-01 \\
71-12\end{array}$ & $\begin{array}{c}881 \mathrm{~B} \\
14 \\
6 \mathrm{H}-02 \\
103-104\end{array}$ & $\begin{array}{c}881 \mathrm{~B} \\
15 \\
6 \mathrm{H}-03 \\
102-103 \\
\end{array}$ & $\begin{array}{c}881 \mathrm{~B} \\
16 \\
6 \mathrm{H}-06 \\
106-107 \\
\end{array}$ & $\begin{array}{c}881 \mathrm{~B} \\
17 \\
7 \mathrm{H}-05 \\
115-116\end{array}$ & $\begin{array}{c}881 \mathrm{~B} \\
18 \\
7 \mathrm{H}-06 \\
116-117 \\
\end{array}$ & $\begin{array}{c}881 \mathrm{~B} \\
19 \\
9 \mathrm{H}-01 \\
43-44\end{array}$ & $\begin{array}{c}881 \mathrm{~B} \\
22 \\
10 \mathrm{H}-05 \\
136-137 \\
\end{array}$ & $\begin{array}{c}881 \mathrm{~B} \\
25 \\
11 \mathrm{H}-01 \\
110-111\end{array}$ \\
\hline $\begin{array}{l}\mathrm{SiO}_{2} \\
\mathrm{TiO}_{2} \\
\mathrm{Al}_{2} \mathrm{O}_{3} \\
\mathrm{FeO}^{*} \\
\mathrm{MnO} \\
\mathrm{MgO} \\
\mathrm{CaO} \\
\mathrm{K}_{2} \mathrm{O} \\
\mathrm{Na}_{2} \mathrm{O} \\
\mathrm{Total}\end{array}$ & $\begin{array}{r}76.31 \\
0.30 \\
13.69 \\
1.95 \\
0.00 \\
0.09 \\
2.00 \\
2.15 \\
3.49 \\
98.49\end{array}$ & $\begin{array}{r}74.53 \\
0.34 \\
13.74 \\
2.10 \\
0.00 \\
0.16 \\
2.19 \\
3.00 \\
3.92 \\
101.15\end{array}$ & $\begin{array}{r}76.00 \\
0.37 \\
14.67 \\
2.38 \\
0.00 \\
0.11 \\
2.32 \\
1.37 \\
2.78 \\
99.27\end{array}$ & $\begin{array}{r}78.39 \\
0.18 \\
12.67 \\
1.37 \\
0.00 \\
0.00 \\
1.50 \\
2.09 \\
3.78 \\
95.04\end{array}$ & $\begin{array}{r}77.22 \\
0.28 \\
12.91 \\
2.18 \\
0.10 \\
0.17 \\
2.13 \\
1.87 \\
3.14 \\
95.13\end{array}$ & $\begin{array}{r}80.50 \\
0.17 \\
12.59 \\
1.34 \\
0.00 \\
0.00 \\
1.43 \\
2.03 \\
1.93 \\
93.24\end{array}$ & $\begin{array}{r}77.66 \\
0.21 \\
13.23 \\
1.35 \\
0.00 \\
0.02 \\
1.62 \\
2.13 \\
3.81 \\
97.84\end{array}$ & $\begin{array}{r}73.67 \\
0.33 \\
14.30 \\
2.51 \\
0.00 \\
0.05 \\
1.72 \\
2.78 \\
4.77 \\
96.57\end{array}$ & $\begin{array}{r}81.03 \\
0.10 \\
12.22 \\
0.98 \\
0.00 \\
0.00 \\
1.00 \\
2.80 \\
1.91 \\
96.47\end{array}$ & $\begin{array}{r}70.18 \\
0.52 \\
15.26 \\
3.86 \\
0.00 \\
0.32 \\
2.32 \\
2.49 \\
5.10 \\
100.55\end{array}$ & $\begin{array}{r}73.25 \\
0.54 \\
15.05 \\
2.78 \\
0.08 \\
0.29 \\
1.99 \\
2.11 \\
3.90 \\
98.40\end{array}$ & $\begin{array}{r}79.85 \\
0.31 \\
12.06 \\
2.02 \\
0.00 \\
0.09 \\
2.40 \\
0.74 \\
2.55 \\
95.11\end{array}$ & $\begin{array}{r}78.83 \\
0.02 \\
12.58 \\
0.57 \\
0.00 \\
0.00 \\
0.54 \\
4.36 \\
3.12 \\
95.68\end{array}$ & $\begin{array}{r}79.73 \\
0.02 \\
12.77 \\
0.53 \\
0.00 \\
0.00 \\
0.46 \\
4.01 \\
2.48 \\
97.40\end{array}$ & $\begin{array}{r}79.30 \\
0.00 \\
12.20 \\
0.95 \\
0.00 \\
0.00 \\
1.05 \\
3.36 \\
3.17 \\
94.80\end{array}$ & $\begin{array}{r}62.81 \\
1.03 \\
15.81 \\
7.10 \\
0.03 \\
2.19 \\
5.69 \\
1.52 \\
3.84 \\
98.85\end{array}$ & $\begin{array}{r}75.58 \\
0.56 \\
13.32 \\
2.49 \\
0.00 \\
0.12 \\
1.96 \\
2.66 \\
3.33 \\
95.66\end{array}$ \\
\hline $\begin{array}{l}{ }^{143} \mathrm{Nd}^{144} \mathrm{Nd} \\
{ }^{87} \mathrm{Sr} /{ }^{86} \mathrm{Sr}\end{array}$ & $\begin{array}{l}0.512933 \\
0.703509\end{array}$ & & & $\begin{array}{l}0.513110 \\
0.703625\end{array}$ & & & & $\begin{array}{l}0.513065 \\
0.703403\end{array}$ & & & & $\begin{array}{l}0.513058 \\
0.703586\end{array}$ & & & & & \\
\hline $\mathrm{Sc}$ & 23 & 11 & 22 & 12 & 11 & 13 & 11 & 18 & 8 & 14 & 25 & 17 & 3 & 5 & 9 & 24 & 24 \\
\hline $\mathrm{V}$ & 60 & 40 & 23 & 13 & 20 & 18 & 14 & 24 & 5 & 33 & 29 & 8 & 0 & 0 & 1 & 106 & 71 \\
\hline $\mathrm{Cr}$ & 4 & 11 & 2 & 1 & 0 & 3 & 0 & 1 & 1 & 14 & 5 & 0 & 1 & 1 & 1 & 2 & 22 \\
\hline Co & 6 & 5 & 4 & 3 & 5 & 2 & 2 & 4 & 2 & 4 & 3 & 3 & 1 & 1 & 2 & 11 & 9 \\
\hline $\mathrm{Ni}$ & 6 & 7 & 8 & 0 & 7 & 3 & 0 & 6 & 0 & 6 & 12 & 0 & 0 & 0 & 0 & 13 & 17 \\
\hline $\mathrm{Cu}$ & 38 & 17 & 17 & 7 & 6 & 5 & 4 & 11 & 7 & 15 & 8 & 8 & 4 & 4 & 9 & 43 & 50 \\
\hline $\mathrm{Zn}$ & 50 & 32 & 58 & 43 & 39 & 41 & 31 & 58 & 30 & 59 & 56 & 41 & 23 & 21 & 31 & 89 & 54 \\
\hline $\mathrm{Ga}$ & 14 & 12 & 14 & 12 & 11 & 11 & 9 & 15 & 31 & 13 & 16 & 11 & 31 & 30 & 28 & 18 & 17 \\
\hline $\mathrm{Ge}$ & 1 & 1 & 2 & 1 & 4 & 1 & 1 & 1 & 2 & 1 & 5 & 1 & 2 & 2 & 2 & 1 & 2 \\
\hline R! & 37.0 & 53.1 & 26.9 & 46.9 & 50.1 & 66.2 & 47.5 & 23.8 & 115.6 & 69.8 & 38.5 & 14.9 & 185.2 & 188.1 & 118.5 & 28.1 & 65.0 \\
\hline $\mathrm{Sr}$ & 171 & 181 & 216 & 152 & 187 & 160 & 159 & 206 & oro & 199 & 216 & 165 & 56 & 48 & 73 & 336 & 190 \\
\hline $\mathrm{Zr}$ & 178.7 & 89.2 & 137.2 & 162.4 & 147.2 & 152.6 & 145.4 & 122.0 & 151.4 & 185.5 & 164.3 & 99.9 & 63.6 & 62.4 & 123.2 & 145.3 & 171.4 \\
\hline $\mathrm{Nb}$ & 2.04 & 8.62 & 2.20 & 2.36 & 2.08 & 2.63 & 1.78 & 2.08 & 3.26 & 5.59 & 4.72 & 0.62 & 7.47 & 7.49 & 5.48 & 3.94 & 5.20 \\
\hline Mo & 2.46 & 2.84 & 1.75 & 2.09 & 1.97 & 2.11 & 1.66 & 1.65 & 3.82 & 1.60 & 2.01 & 1.38 & 1.61 & 1.66 & 3.56 & 1.52 & 2.00 \\
\hline Sn & 2.44 & 2.08 & 1.03 & 2.19 & 0.96 & 1.52 & 0.70 & $\begin{array}{r}1.92 \\
17.7\end{array}$ & 1.08 & 1.25 & 2.55 & 2.06 & 1.67 & 1.68 & 1.91 & 2.23 & 1.16 \\
\hline $\mathrm{Ba}$ & 417.8 & 562.3 & 271.5 & 597.4 & 483.3 & 629.8 & 489.5 & 247.7 & 897.4 & 611.5 & 497.9 & 273.9 & 870.7 & 868.1 & 804.1 & 480.8 & 605.2 \\
\hline $\mathrm{La}$ & 9.18 & 14.43 & 8.22 & 14.56 & 11.93 & 15.28 & 12.37 & 8.24 & 18.31 & 14.98 & 12.21 & 5.23 & 22.08 & 21.00 & 20.96 & 13.11 & 13.41 \\
\hline $\mathrm{Ce}$ & 23.81 & 30.05 & 19.47 & 33.84 & 27.86 & 35.17 & 28.82 & 21.49 & 38.37 & 34.90 & 28.82 & 14.96 & 45.00 & 43.42 & 45.54 & 32.88 & 32.44 \\
\hline $\operatorname{Pr}$ & 3.69 & 3.67 & 3.16 & 4.62 & 3.81 & 4.83 & 3.90 & 3.31 & 4.60 & 5.11 & 4.23 & 2. & 4.93 & 4.73 & 5.47 & 5.07 & 4.79 \\
\hline $\mathrm{Nd}$ & 16.52 & 13.59 & 15.3 & 19.63 & 16.47 & 19.90 & 16.90 & 15.19 & 16.94 & 21.17 & 18.58 & 12.1 & 16.6 & 15.89 & 20. & 24.04 & 20.85 \\
\hline Sm & 4.89 & 2.88 & 4. & 5.14 & 4.26 & 5.04 & 4.42 & 4.50 & 3.78 & 5. & 4.74 & 4. & 3. & 3. & 4. & 4 & 5.32 \\
\hline Eu & 1. & 0.9 & 1.2 & 1. & & 1.12 & 0.97 & 1. & 0.92 & 1. & 1. & 1. & 0.8 & 0.8 & 0. & 4 & 1.26 \\
\hline $\mathrm{Gd}$ & 5.6 & 3.3 & 5. & 5. & 4. & 5.68 & 5.13 & 5.2 & 4.34 & 5.7 & 5.4 & 4.7 & 3.8 & 3. & 5. & 6.61 & \\
\hline $\mathrm{Tb}$ & 1.0 & 0. & & & & & 0.9 & 0.9 & 0.7 & 0.9 & 0.9 & 0.9 & 0 & 0. & & & 0.97 \\
\hline Dy & 7. & 3. & 6. & 6. & 5. & 6.2 & 5. & & 4. & 6.1 & 5. & 6. & 3. & 3. & 5. & & 5.66 \\
\hline Ho & 1. & 0. & 1. & 1. & 1. & 1.4 & 1.2 & 1.4 & 1. & 1.3 & 1.2 & 1.4 & 0.7 & 0.7 & 1. & & 1.24 \\
\hline Er & 4. & 1. & 4. & 4. & 3. & 4.0 & 3. & 4.1 & 3.0 & 3.7 & 3. & 4. & 2.1 & 2. & 3. & & 3.44 \\
\hline $\mathrm{Tm}$ & 0. & 0. & & & 0. & 0.6 & 0.5 & 0.6 & 0.5 & 0.5 & 0. & 0.6 & 0.3 & 0.3 & 0. & 0.62 & 0.50 \\
\hline $\mathrm{Yb}$ & & 2. & 4. & 4. & 3.9 & 4.36 & 4.01 & 4.5 & 3. & 3.5 & 3.7 & 4.4 & 2. & 2. & 4. & 4.05 & 3.55 \\
\hline Lu & 0. & 0.35 & 0.70 & 0. & 0.6 & 0.70 & 0.6 & 0.7 & 0.6 & 0. & 0. & 0.7 & 0. & 0. & 0. & 0.65 & 0.56 \\
\hline $\mathrm{Hf}$ & 5.14 & 2.80 & 3.62 & 4.5 & 3.89 & 3.81 & 3.76 & 3.43 & 4.32 & 4.33 & 4.2 & 3.1 & 2.52 & 2.50 & 4.22 & 3.92 & 3.92 \\
\hline Ta & 0.17 & 0.83 & 0.22 & 0.19 & 0.21 & 0.24 & 0.20 & 0.17 & 0.31 & 0.42 & 0.35 & 0.06 & 0.85 & 0.88 & 0.52 & 0.27 & 0.39 \\
\hline $\mathrm{Pb}$ & 18.65 & 12.40 & 14.90 & 14.59 & 17.80 & 18.45 & 18.13 & 9.47 & 24.40 & 17.33 & 13.55 & 10.88 & 22.09 & 22.29 & 27.03 & 8.65 & 17.62 \\
\hline Th & 2.23 & 3.86 & 1.69 & 4.75 & 4.4 & 5.32 & 4.53 & 1.50 & 10.65 & 2. & 2.2 & 1.04 & 13.63 & 13.49 & 9.66 & 1.44 & 2.64 \\
\hline U & 1.07 & 1.64 & 0.66 & 1.43 & 1.39 & 1.45 & 1.12 & 0.60 & 3.08 & 1.17 & 2.69 & 0.49 & 4.14 & 4.32 & 2.31 & 0.92 & 1.27 \\
\hline
\end{tabular}


Table 9 (continued).

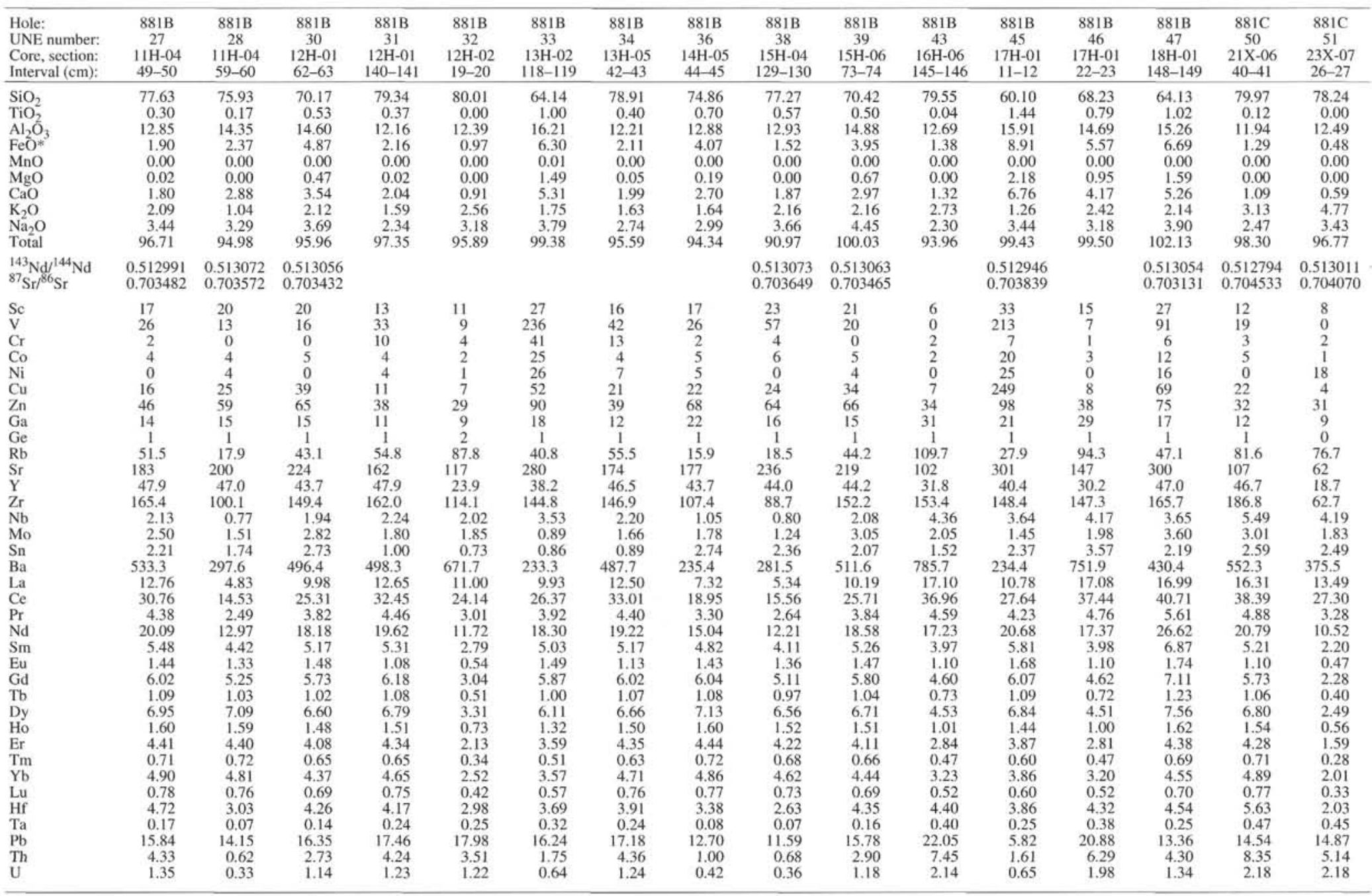

otes: UNE number refers to the ash layer number analyzed at UNE (see Table 1). Major elements are averages of individual shard analyses from the same layer. Major elements reported as wt\% oxides and trace elements as parts per million. All Fe reported as $\mathrm{FeO}^{*}$. 


\begin{tabular}{|c|c|c|c|c|c|c|c|c|c|c|c|c|c|c|c|}
\hline $\begin{array}{l}\text { UNE number: } \\
\text { Core, section: } \\
\text { Interval }(\mathrm{cm}):\end{array}$ & $\begin{array}{c}54 \\
1 \mathrm{H}-6 \\
83-84 \\
\end{array}$ & $\begin{array}{c}55 \\
2 \mathrm{H}-5 \\
21-22\end{array}$ & $\begin{array}{c}56 \\
2 \mathrm{H}-6 \\
148-149 \\
\end{array}$ & $\begin{array}{c}57 \\
2 \mathrm{H}-7 \\
17-18 \\
\end{array}$ & $\begin{array}{c}58 \\
3 \mathrm{H}-4 \\
18-19 \\
\end{array}$ & $\begin{array}{c}59 \\
3 \mathrm{H}-4 \\
118-120 \\
\end{array}$ & $\begin{array}{c}60 \\
4 \mathrm{H}-5 \\
12-13 \\
\end{array}$ & $\begin{array}{c}61 \\
5 \mathrm{H}-4 \\
149-150\end{array}$ & $\begin{array}{c}62 \\
6 \mathrm{H}-1 \\
32-33 \\
\end{array}$ & $\begin{array}{c}63 \\
6 \mathrm{H}-4 \\
29-30\end{array}$ & $\begin{array}{c}64 \\
8 \mathrm{H}-2 \\
133-135 \\
\end{array}$ & $\begin{array}{c}65 \\
8 \mathrm{H}-3 \\
12-13 \\
\end{array}$ & $\begin{array}{c}67 \\
8 \mathrm{H}-6 \\
54-55 \\
\end{array}$ & $\begin{array}{c}68 \\
8 \mathrm{H}-7 \\
12-13\end{array}$ & $\begin{array}{c}69 \\
9 \mathrm{H}-2 \\
14-15 \\
\end{array}$ \\
\hline $\mathrm{SiO}_{2}$ & 69.06 & 71.2 & 68.58 & 67.92 & 79.58 & 78.16 & 73.38 & 70.03 & 73.35 & 74.1 & 70.71 & 77.78 & 75.56 & 72.49 & 69.99 \\
\hline $\mathrm{TiO}_{2}$ & 0.93 & 0.58 & 0.95 & 0.93 & 0.09 & 0.18 & 0.63 & 0.59 & 0.61 & 0.4 & 0.67 & 0.14 & 0.07 & 0.48 & 0.78 \\
\hline $\mathrm{Al}_{2} \mathrm{O}_{3}$ & 15.62 & 15.69 & 14.21 & 15.88 & 12.88 & 13.17 & 14.22 & 14.93 & 13.98 & 14.04 & 13.97 & 13.01 & 14.32 & 13.71 & 14.26 \\
\hline $\mathrm{FeO}^{*}$ & 3.82 & 2.38 & 6.32 & 4.68 & 1.49 & 1.53 & 3.16 & 5.04 & 3.24 & 3.38 & 4.33 & 0.89 & 1.32 & 5.07 & 5.31 \\
\hline $\mathrm{MnO}$ & 0.01 & 0 & 0 & 0 & 0 & 0 & 0 & 0 & 0 & 0 & 0 & 0 & 0 & 0 & 0 \\
\hline $\mathrm{MgO}$ & 0.65 & 0.27 & 0.8 & 0.94 & 0 & 0.06 & 0.13 & 0.73 & 0.44 & 0 & 1.26 & 0.02 & 0.19 & 0.43 & 0.59 \\
\hline $\mathrm{CaO}$ & 2.73 & 1.97 & 3.89 & 3.61 & 1.61 & 1.29 & 1.84 & 4.08 & 2.44 & 1.87 & 4.25 & 0.73 & 2.54 & 3.42 & 3.38 \\
\hline $\mathrm{K}_{2} \mathrm{O}$ & 2.83 & 3.4 & $\begin{array}{l}1.82 \\
\text {. }\end{array}$ & 2.94 & 1.92 & 2.89 & 2.27 & 1.55 & 3.09 & 3.26 & 1.93 & 3.83 & 1.95 & $\begin{array}{l}1.62 \\
\text {. }\end{array}$ & 2.33 \\
\hline $\mathrm{Na}_{2} \mathrm{O}$ & 4.35 & 4.5 & $\begin{array}{l}3.32 \\
3.32\end{array}$ & 3.1 & 2.43 & 2.73 & 4.38 & 3.07 & 2.85 & 2.95 & $\begin{array}{l}2.89 \\
\end{array}$ & $\begin{array}{l}3.60 \\
3.61\end{array}$ & $\begin{array}{l}3.99 \\
3.99\end{array}$ & 2.79 & 3.3 \\
\hline Total & 99.16 & 98.04 & 102.24 & 99.36 & 97.85 & 98.92 & 98.34 & 98.95 & 99.42 & 97.87 & 98.42 & 97.5 & 98.17 & 100.14 & 99.74 \\
\hline $\begin{array}{l}{ }^{143} \mathrm{Nd}^{144} \mathrm{Nd} \\
{ }^{87} \mathrm{Sr} r^{86} \mathrm{Sr}\end{array}$ & & $\begin{array}{l}0.513037 \\
0.703269\end{array}$ & & & $\begin{array}{l}0.513032 \\
0.703828\end{array}$ & & & & $\begin{array}{l}0.513044 \\
0.703409\end{array}$ & $\begin{array}{l}0.513067 \\
0.70346\end{array}$ & & & & $\begin{array}{l}0.513084 \\
0.703575\end{array}$ & $\begin{array}{l}0.513016 \\
0.703419\end{array}$ \\
\hline $\mathrm{Sc}$ & 10 & 18 & 3 & 17 & 26 & 0 & 6 & 14 & 22 & 18 & 28 & 19 & 13 & 20 & 21 \\
\hline $\mathrm{v}$ & 24 & 15 & 6 & 48 & 15 & 36 & 0 & 26 & 65 & 24 & 44 & 0 & 30 & 42 & 58 \\
\hline $\mathrm{Cr}$ & 5 & 0 & 0 & 3 & 1 & 34 & 0 & 0 & 4 & 2 & 0 & 0 & 1 & 1 & 3 \\
\hline $\mathrm{Co}_{0}$ & 4 & 2 & $i$ & 8 & 3 & 7 & 3 & 9 & 7 & 5 & 2 & 0 & 5 & 14 & 9 \\
\hline $\mathrm{Ni}$ & 0 & 0 & 0 & 0 & 18 & 13 & 0 & 0 & 28 & 23 & 4 & 0 & i & 10 & 23 \\
\hline $\mathrm{Cu}$ & 9 & 8 & 3 & 17 & 16 & 27 & 9 & 20 & 15 & 17 & 5 & 7 & 14 & 65 & 27 \\
\hline $\mathrm{Zn}$ & 67 & 57 & 8 & 64 & 37 & 30 & 73 & 79 & 53 & 63 & 51 & 27 & 28 & 74 & 68 \\
\hline $\mathrm{Ga}$ & 30 & 18 & 2 & 25 & 13 & 18 & 20 & 16 & 15 & 15 & 16 & 13 & 11 & 15 & $\begin{array}{l}08 \\
16\end{array}$ \\
\hline $\mathrm{Ge}$ & 1 & 1 & 0 & 1 & 1 & 0 & 1 & 1 & 1 & 1 & 1 & 1 & 1 & 1 & 1 \\
\hline $\mathrm{Rb}$ & 60.4 & 63.4 & 2.2 & 51.5 & $\begin{array}{l}1 \\
36.1\end{array}$ & 20.6 & 41.5 & 28.1 & 55.9 & 59.3 & 40 & 76 & $\begin{array}{l}1 \\
35.4\end{array}$ & 28 & 44 \\
\hline $\mathrm{Sr}$ & 189 & 226 & 26 & 254 & 173 & $309^{\circ}$ & 151 & 307 & 226 & 196 & 207 & 147 & 286 & 239 & 206 \\
\hline $\begin{array}{l}\mathrm{Y} \\
\mathrm{Y}\end{array}$ & 48.4 & 46.8 & 3.3 & 43.1 & 30.2 & 10.2 & 46 & 44.8 & 40.5 & 47.4 & 39.9 & 22.1 & $\begin{array}{c}200 \\
17.1\end{array}$ & 44.4 & 47.1 \\
\hline $\mathrm{Zr}$ & 329.1 & 320.2 & 11.2 & 266.8 & 152.9 & 35.4 & 190.3 & 118.7 & 216.3 & 257.4 & 200.9 & 197 & 132.4 & 121.2 & 222 \\
\hline $\mathrm{Nb}$ & 9.18 & 9.95 & 0.25 & 7.52 & 2.12 & 2.36 & 4.57 & 1.24 & 5.76 & 5.91 & 4.89 & 5.45 & 2.61 & 1.61 & 4.73 \\
\hline Mo & 2.57 & 2.81 & 0.11 & 2.22 & 1.72 & 0.21 & 1.86 & 2.86 & 2.06 & 2.42 & 2.28 & 3.12 & 1.75 & 2.27 & 1.51 \\
\hline Sn & 3.92 & 2.68 & 0.2 & 2.92 & 2.06 & 1.4 & 2.01 & 1.36 & 2.57 & 3.27 & 3.08 & 2.7 & 1.93 & 1.91 & 3.1 \\
\hline $\mathrm{Ba}$ & 915 & 946.1 & 32.2 & 670.8 & 468.4 & 600 & 496.2 & 393.3 & 607.2 & 666.9 & 556.3 & 895.8 & 724.8 & 442 & 418.8 \\
\hline $\mathrm{La}$ & 26.47 & 25.71 & 0.83 & 22.87 & 9.96 & 9.39 & 13.47 & 9.32 & 13.4 & 16.27 & 12.54 & 17.88 & 10.82 & 8.67 & 13.81 \\
\hline $\mathrm{Ce}$ & 63.14 & 59.49 & 2.13 & 58.13 & 23.2 & 19.48 & 33.22 & 23.84 & 32.92 & 40.64 & 30.03 & $\begin{array}{l}38.05 \\
38.05\end{array}$ & $\begin{array}{l}23.02 \\
23.45\end{array}$ & 22.59 & 35.43 \\
\hline $\mathrm{Pr}$ & 8.45 & 7.86 & 0.33 & 7.46 & 3.25 & 2.67 & 4.91 & 3.66 & 4.82 & 5.95 & 4.4 & 4.76 & 3.11 & 3.43 & 5.24 \\
\hline $\mathrm{Nd}$ & 35.16 & 34.41 & $\begin{array}{l}1.5 \\
1.5\end{array}$ & $\begin{array}{r}3.40 \\
32.92\end{array}$ & 13.34 & $\begin{array}{l}2.01 \\
9.3\end{array}$ & 22.03 & $\begin{array}{r}3.00 \\
17.23\end{array}$ & 20.59 & 25.84 & $\begin{array}{l}4.4 \\
19.01\end{array}$ & 17.41 & 12.24 & 16.46 & 23.44 \\
\hline Sm & $\begin{array}{r}53.10 \\
7.84\end{array}$ & $\begin{array}{r}7.471 \\
7.78\end{array}$ & 0.43 & $\begin{array}{r}32.92 \\
7.39\end{array}$ & $\begin{array}{l}3.34 \\
3.38\end{array}$ & 2.02 & $\begin{array}{r}5.03 \\
5.76\end{array}$ & 5.04 & $\begin{array}{r}20.39 \\
5.35\end{array}$ & $\begin{array}{r}6.54 \\
6.59\end{array}$ & $\begin{array}{r}19.01 \\
4.84\end{array}$ & $\begin{array}{r}17.41 \\
3.39\end{array}$ & 2.68 & $\begin{array}{r}10.40 \\
4.93\end{array}$ & 6.33 \\
\hline $\begin{array}{l}\mathrm{Sm} \\
\mathrm{Eu}\end{array}$ & $\begin{array}{l}.1 .84 \\
2.03\end{array}$ & 2.12 & $\begin{array}{l}0.43 \\
0.14\end{array}$ & $\begin{array}{l}1.39 \\
1.98\end{array}$ & $\begin{array}{l}3.38 \\
1.01\end{array}$ & 0.77 & $\begin{array}{l}1.10 \\
1.66\end{array}$ & $\begin{array}{l}1.04 \\
1.55\end{array}$ & $\begin{array}{l}1.56 \\
1.56\end{array}$ & $\begin{array}{l}0.39 \\
1.7\end{array}$ & $\begin{array}{l}4.84 \\
1.33\end{array}$ & $\begin{array}{l}5.39 \\
1.04\end{array}$ & 1.03 & $\begin{array}{l}4.93 \\
1.4\end{array}$ & $\begin{array}{l}0.33 \\
1.62\end{array}$ \\
\hline $\mathrm{Gd}$ & 7.91 & 7.6 & 0.48 & 7.72 & 3.82 & 2.52 & 6.45 & 5.9 & 6.12 & 7.25 & 5.41 & 3.39 & 2.95 & 5.4 & 7.06 \\
\hline $\mathrm{Tb}$ & 1.22 & 1.25 & 0. & 1.19 & 0.66 & 0.31 & $\begin{array}{l}1.11 \\
1.11\end{array}$ & 1.06 & 0.98 & 1.18 & 0.93 & 0.52 & 0.43 & 1.0 & 21.2 \\
\hline Dy & 7.3 & 7.44 & 0.52 & 6.8 & 4.2 & 1.76 & 6.93 & 6.7 & 6.03 & 7.3 & 5.96 & 3.09 & 2.71 & 6.66 & 7.41 \\
\hline Ho & 1.58 & 1.61 & 0.11 & $\begin{array}{l}1.49 \\
\text {. }\end{array}$ & 0.94 & 0.36 & $\begin{array}{l}1.58 \\
1.58\end{array}$ & $\begin{array}{l}0.1 \\
1.52\end{array}$ & $\begin{array}{l}1.33 \\
1.33\end{array}$ & 1.6 & 1.32 & 0.6 & 0.58 & $\begin{array}{l}1.49 \\
1.49\end{array}$ & 1.64 \\
\hline $\mathrm{Er}$ & 4.44 & 4.34 & 0.3 & 4.13 & 2.7 & 1 & 4.41 & 4.27 & 3.64 & 4.47 & 3.54 & 1.98 & 1.66 & 4.12 & 4.47 \\
\hline $\mathrm{Tm}$ & 0.71 & 0.72 & 0.6 & 0. & 0.4 & 0.15 & 0.7 & 0.67 & 0.59 & 0.72 & 0.57 & 0.35 & 0.29 & 0.66 & 0.7 \\
\hline $\mathrm{Yb}$ & 4.83 & 4.78 & 0.33 & 4.41 & 3.1 & 1.02 & 4.77 & 4.56 & 3.91 & 4.83 & 3.94 & 2.48 & 2.04 & 4.49 & 4.65 \\
\hline $\mathrm{Lu}$ & 0.78 & 0.76 & 0.05 & 0.69 & 0.51 & 0.15 & 0.77 & 0.73 & 0.62 & 0.77 & 0.61 & 0.41 & 0.35 & 0.71 & 0.72 \\
\hline $\mathrm{Hf}$ & 7.52 & 7.67 & 0.31 & 6.54 & 3.94 & 0.94 & 5.08 & 3.51 & 5.44 & 6.77 & 5 & 4.98 & 3.73 & 3.54 & 5.94 \\
\hline $\mathrm{Ta}$ & 0.59 & 0.65 & 0.02 & 0.53 & 0.18 & 0.17 & 0.33 & 0.09 & 0.44 & 0.44 & 0.37 & 0.47 & 0.23 & 0.12 & 0.37 \\
\hline $\begin{array}{l}\mathrm{Pb} \\
\mathrm{Pb}\end{array}$ & 14.61 & 12.73 & 0.58 & 12.08 & 13.55 & 4.93 & 6.7 & 10.94 & 11.41 & 12.55 & 11.46 & $\begin{array}{l}0.47 \\
17.9\end{array}$ & 15.31 & 14.78 & 12.55 \\
\hline Th & $\begin{array}{r}34.01 \\
3.71\end{array}$ & 4.17 & 0.12 & 3.66 & 1.92 & $\begin{array}{l}4.93 \\
2.23\end{array}$ & 2.84 & 2.06 & 2.85 & 3.05 & 2.09 & 4.74 & 2.49 & $\begin{array}{r}1.69 \\
1.69\end{array}$ & 2.6 \\
\hline $\mathrm{U}$ & 1.58 & 1.68 & 0.07 & 1.55 & 0.82 & 0.9 & 1.51 & 0.88 & 1.74 & 1.95 & 1.11 & 1.96 & 1.15 & 0.78 & 1.27 \\
\hline
\end{tabular}


Table 10 (continued).

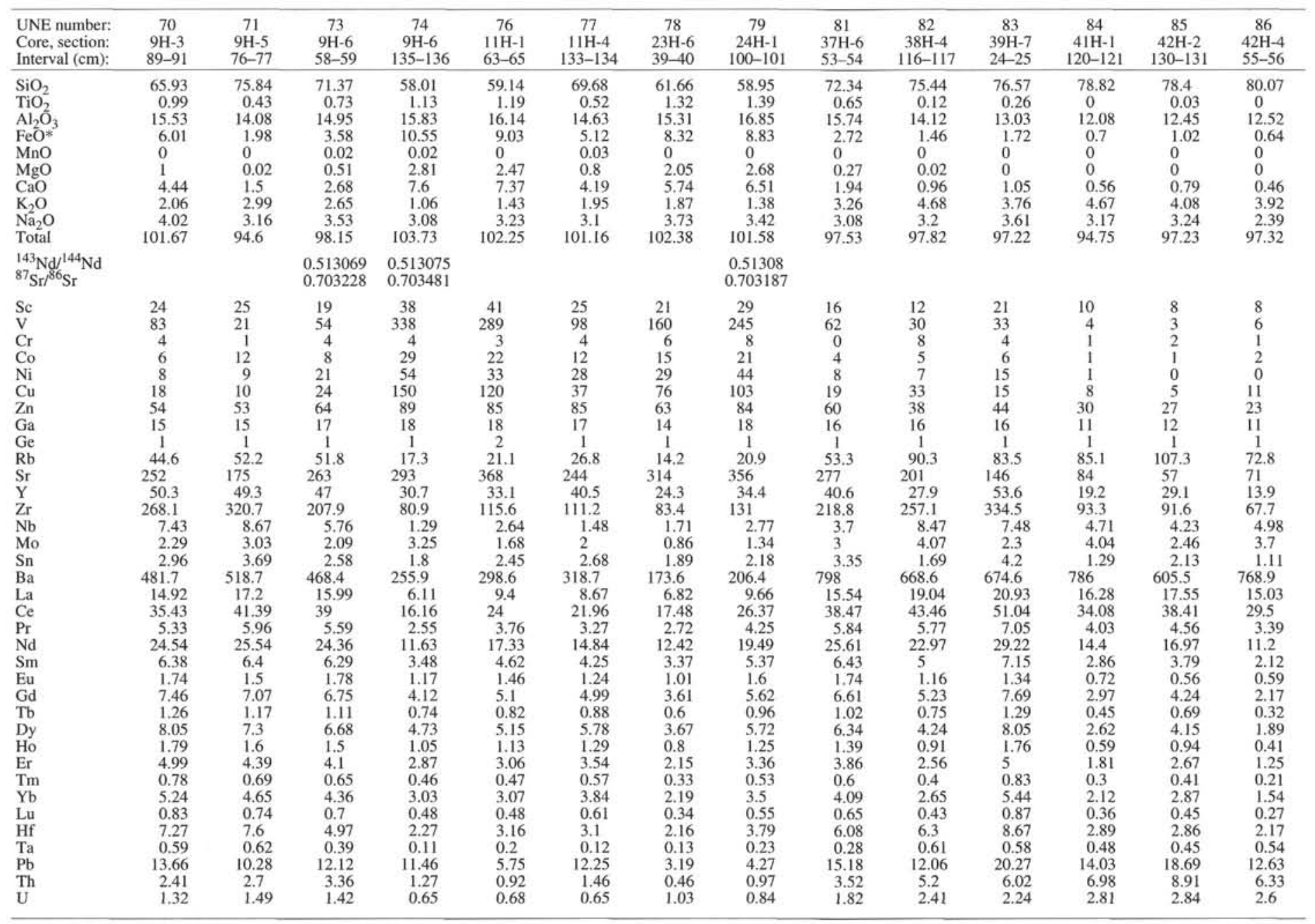

Notes: UNE number refers to the ash layer number analyzed at UNE (see Table 2). Major elements are averages of individual shard analyses from the same layer. Major elements reported as wt\% oxides and trace elements as parts per million. All Fe reported as FeO*. 

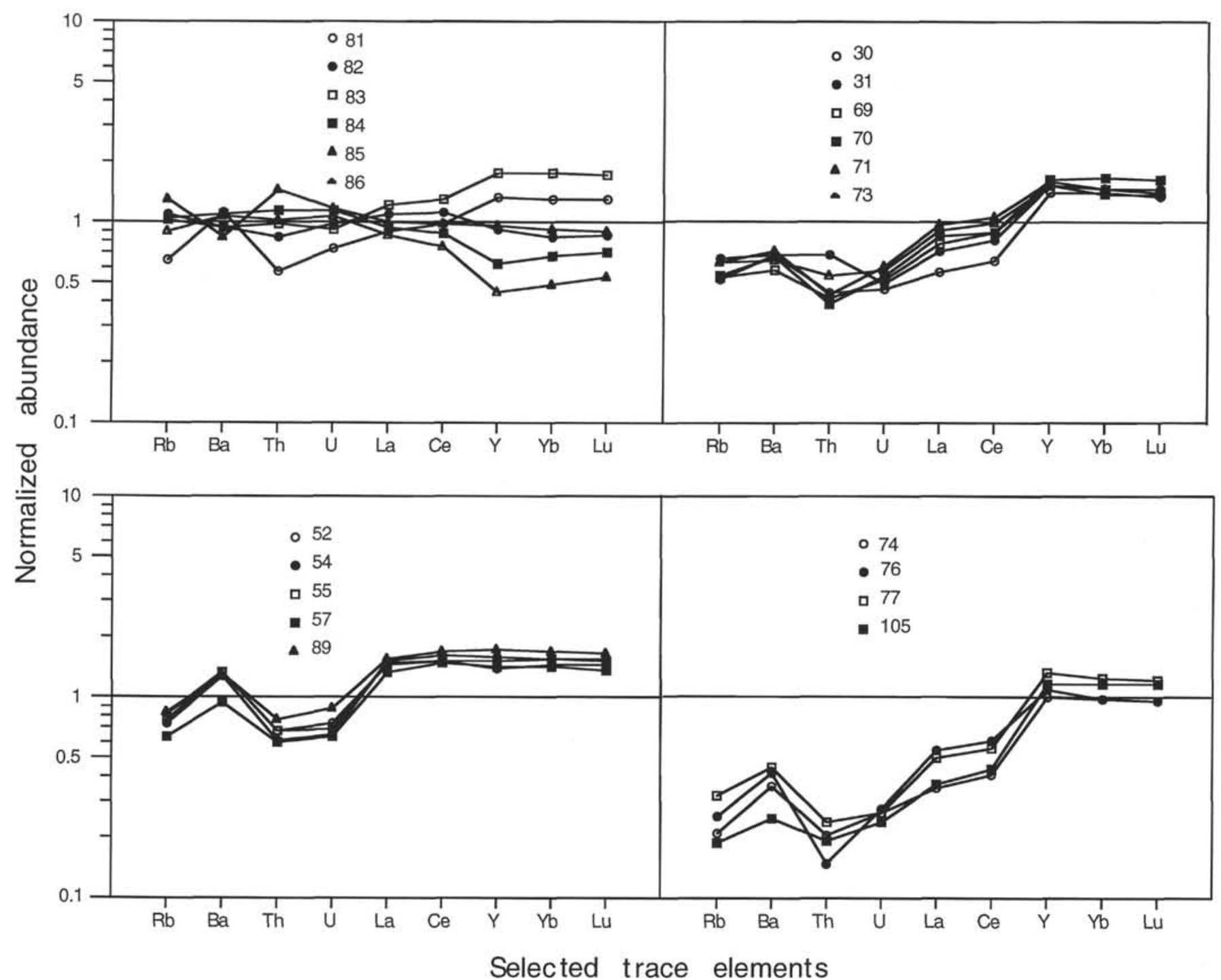

Figure 8. Normalized abundances of selected trace elements for different groups of ashes (UNE layer numbers indicated by specific symbols). Normalizing factors are the averages of element abundances for a group of Miocene high- $\mathrm{K}$ ashes.

teristics of a range of compositions is consistent with such processes, but the near isotopic identity of the basement of EK with primary upper mantle-derived arc magmas makes detection of crustal melting and assimilation difficult to detect (B. Castellana, pers. comm., 1994). The ubiquity of negative Eu anomalies and concave-upward $\mathrm{Gd}$ to $\mathrm{Lu}$ REE patterns in the intermediate-to-felsic compositions signify extensive plagioclase and amphibole fractionation, or the persistence of these phases in a crustal source undergoing partial melting.

4. There is no evidence for any consistent temporal trends in the geochemistry of the ashes. Comparison of major element parameters that are believed to correlate globally with crustal thicknesses in arcs among the Leg 145 ashes, rock samples collected from active volcanoes in Kamchatka, and ashes from the Izu-Bonin-Mariana system lead to some surprising conclusions: (1) no evidence for crustal thickening with time based on the Leg 145 ash compositions; (2) an apparent increase in crustal thickening manifested by a lower $\mathrm{CaO}$ content at specific $\mathrm{MgO}$ content of the land samples compared with the ashes, which is inconsistent with known tectonic features in Kamchatka; and (3) a coincidence of all of the ash compositions whether from the Kurile-Kamchatka or Izu-Bonin-Mariana arcs.

5. A global increase of explosive activity in arc systems occurred in the period $5 \mathrm{Ma}$ to present, and in the northern Pacific, a further increase in intensity was initiated at $2.6 \mathrm{Ma}$.
6. Finally, we note the decoupling of characteristics $(\mathrm{FeO} * / \mathrm{MgO}$ at specific $\mathrm{SiO}_{2}$, low- vs. medium- to high-K, level of absolute light REE abundances, and the La/Y ratio) commonly believed to be collectively distinguishing features of tholeiitic vs. calcalkaline rock series is demonstrable in these Leg 145 ashes.

\section{ACKNOWLEDGMENTS}

The support of David Rea for our involvement in this study is greatly appreciated, as is the diligence of the shipboard scientific party in providing representative sampling of critical samples. Our research was funded by a grant from the Australian Research Council (ARC). Peter Garlick and Rick Porter ensured the EMP at UNE was available and functional. Rikki Davidson was responsible for ensuring the consistent productivity of the ion-exchange columns at UNE, and the staff members of the jointly funded (ARC and Commonwealth Scientific Industrial Research Organisation) Center for Isotope Studies are thanked for their outstanding cooperation in the generation of high quality data. The tolerance of Dr. David Lambert at the Monash ICP-MS facility is much appreciated. L.-Q. Cao was supported by Overseas Postgraduate Research and UNE Overseas Student scholarships. We thank Jon Davidson and Ben Castellana for their detailed and constructive reviews. 
Table 11. Bulk major and trace element analyses of Paleogene ash layers from Sites 883 and 884.

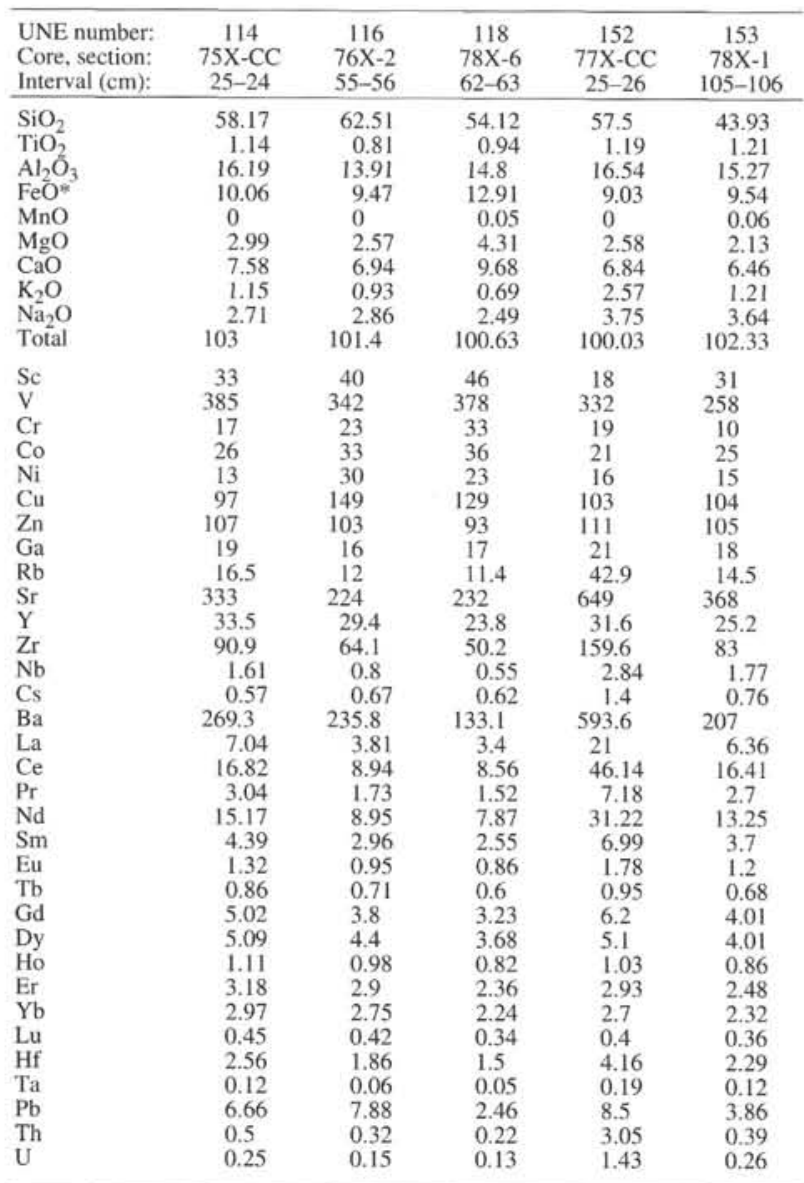

Notes: UNE number refers to the ash layer number analyzed at UNE (see Tables 3 and 4). Major elements are averages of individual shard analyses from the same layer. Major elements reported as wt\% oxides and trace elements as parts per million. All Fe reported as $\mathrm{FeO}^{*}$.

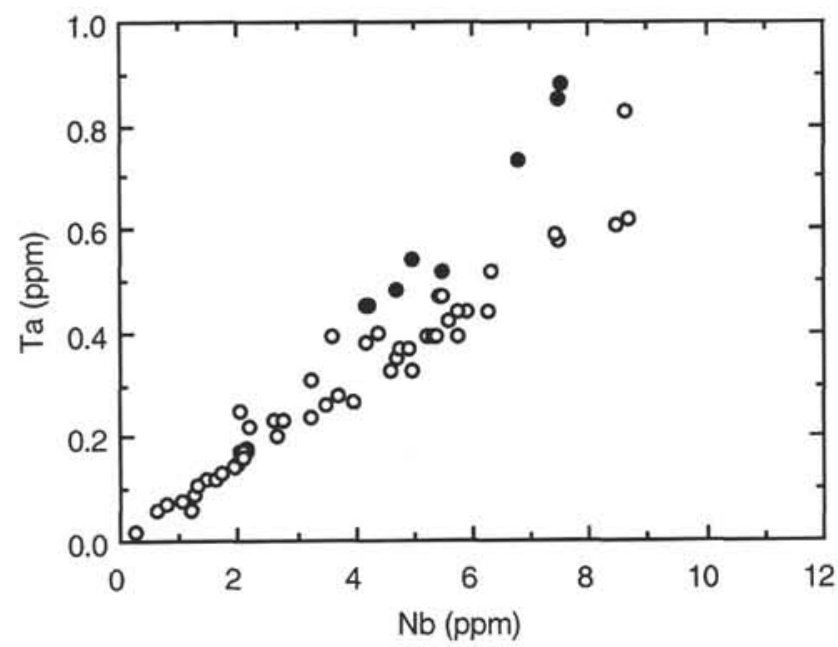

Figure 9. Variation of Ta vs. $\mathrm{Nb}$ for ashes from Sites $881-884$, with the Miocene high-K samples distinguished by solid circles. Open circles represent all other analyzed samples.

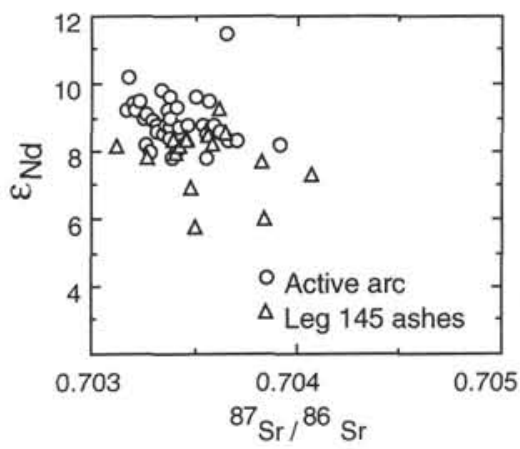

Figure 10. $\varepsilon_{\mathrm{Nd}}$ (deviation in parts per ten thousand of the sample compared with a ${ }^{143} \mathrm{Nd} /{ }^{144} \mathrm{Nd}$ chondritic standard of 0.512638 ) vs. ${ }^{87} \mathrm{Sr} /{ }^{86} \mathrm{Sr}$ for ashes from Sites 881 through 884 compared with active volcanoes from the Central Kamchatka Depression and East Kamchatka.

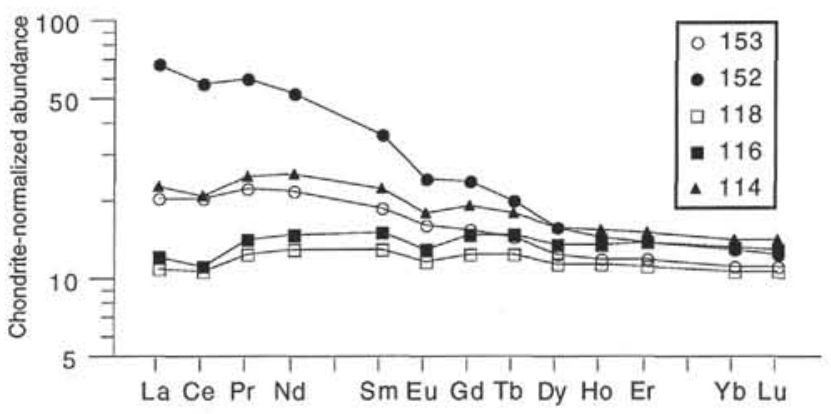

Figure 11. Chondrite-normalized rare earth element abundances for Paleogene ashes from Sites 883 and 884 . Numbers by the symbols for each pattern are the UNE layer numbers.

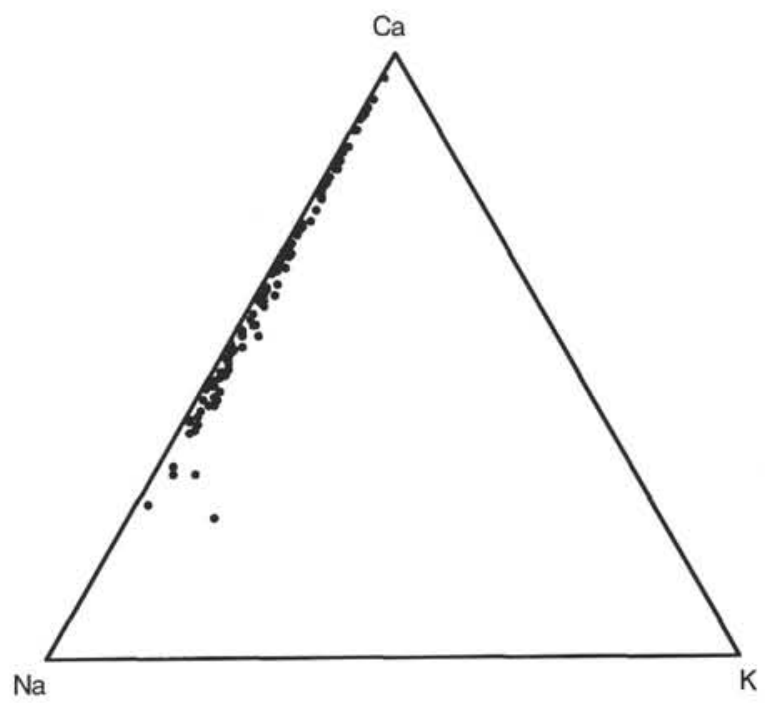

Figure 12. Projections of plagioclase compositions in terms of atomic proportions of $\mathrm{Ca}, \mathrm{Na}$, and $\mathrm{K}$. 
Table 12. Representative analyses of plagioclase from Site 881 .

\begin{tabular}{|c|c|c|c|c|c|c|c|c|c|c|c|c|c|c|c|}
\hline $\begin{array}{l}\text { Hole: } \\
\text { UNE number: }\end{array}$ & $\begin{array}{c}881 \mathrm{~A} \\
1\end{array}$ & $\begin{array}{c}881 \mathrm{~A} \\
1\end{array}$ & $\begin{array}{c}881 \mathrm{~A} \\
2\end{array}$ & $\begin{array}{c}881 \mathrm{~A} \\
2\end{array}$ & $\begin{array}{c}881 \mathrm{~A} \\
3\end{array}$ & $\begin{array}{c}881 \mathrm{~A} \\
3\end{array}$ & $\begin{array}{c}881 \mathrm{~A} \\
3\end{array}$ & $\begin{array}{c}881 \mathrm{~A} \\
3\end{array}$ & $\begin{array}{c}881 \mathrm{~A} \\
4\end{array}$ & $\begin{array}{c}881 \mathrm{~A} \\
4\end{array}$ & $\begin{array}{c}881 \mathrm{~A} \\
4\end{array}$ & $\begin{array}{c}881 \mathrm{~A} \\
4\end{array}$ & $\begin{array}{c}881 \mathrm{~A} \\
4\end{array}$ & $\begin{array}{c}881 \mathrm{~B} \\
6\end{array}$ & $\begin{array}{c}881 \mathrm{~B} \\
6\end{array}$ \\
\hline $\begin{array}{l}\mathrm{SiO}_{2} \\
\mathrm{Al}_{2} \mathrm{O}_{3} \\
\mathrm{FeO}^{*} \\
\mathrm{CaO} \\
\mathrm{BaO} \\
\mathrm{K}_{2} \mathrm{O} \\
\mathrm{Na}_{2} \mathrm{O}\end{array}$ & $\begin{array}{r}55.58 \\
28.14 \\
0.20 \\
9.89 \\
0.27 \\
0.26 \\
5.95\end{array}$ & $\begin{array}{r}56.65 \\
27.69 \\
0.14 \\
8.36 \\
0.26 \\
0.18 \\
7.11\end{array}$ & $\begin{array}{r}51.52 \\
30.40 \\
1.07 \\
12.58 \\
0.28 \\
0.39 \\
4.03\end{array}$ & $\begin{array}{r}50.34 \\
31.68 \\
0.47 \\
14.15 \\
0.27 \\
0.12 \\
3.26\end{array}$ & $\begin{array}{r}46.02 \\
34.44 \\
0.78 \\
17.22 \\
0.26 \\
0.16 \\
1.28\end{array}$ & $\begin{array}{r}50.82 \\
31.30 \\
0.61 \\
13.25 \\
0.26 \\
0.20 \\
3.82\end{array}$ & $\begin{array}{r}57.64 \\
27.09 \\
0.28 \\
8.15 \\
0.27 \\
0.11 \\
6.74\end{array}$ & $\begin{array}{r}45.82 \\
34.84 \\
0.50 \\
17.41 \\
0.27 \\
0.09 \\
1.33\end{array}$ & $\begin{array}{r}56.07 \\
27.97 \\
0.16 \\
9.41 \\
0.27 \\
0.16 \\
6.25\end{array}$ & $\begin{array}{r}52.75 \\
30.18 \\
0.43 \\
12.03 \\
0.27 \\
0.09 \\
4.51\end{array}$ & $\begin{array}{r}57.53 \\
26.99 \\
0.23 \\
8.10 \\
0.27 \\
0.42 \\
6.75\end{array}$ & $\begin{array}{r}56.50 \\
27.67 \\
0.30 \\
9.41 \\
0.27 \\
0.16 \\
5.96\end{array}$ & $\begin{array}{r}56.01 \\
27.85 \\
0.50 \\
9.52 \\
0.27 \\
0.26 \\
5.86\end{array}$ & $\begin{array}{r}59.75 \\
25.73 \\
0.15 \\
6.61 \\
0.28 \\
0.37 \\
7.54\end{array}$ & $\begin{array}{r}56.90 \\
27.54 \\
0.15 \\
8.53 \\
0.27 \\
0.28 \\
6.58\end{array}$ \\
\hline $\begin{array}{l}\text { Hole: } \\
\text { UNE number: }\end{array}$ & $\begin{array}{c}881 \mathrm{~B} \\
6\end{array}$ & $\begin{array}{c}881 \mathrm{~B} \\
7\end{array}$ & $\begin{array}{c}881 \mathrm{~B} \\
8\end{array}$ & $\begin{array}{c}881 \mathrm{~B} \\
8\end{array}$ & $\begin{array}{c}881 \mathrm{~B} \\
8\end{array}$ & $\begin{array}{c}881 \mathrm{~B} \\
9\end{array}$ & $\begin{array}{c}881 \mathrm{~B} \\
9\end{array}$ & $\begin{array}{c}881 \mathrm{~B} \\
11\end{array}$ & $\begin{array}{c}881 \mathrm{~B} \\
12\end{array}$ & $\begin{array}{c}881 \mathrm{~B} \\
12\end{array}$ & $\begin{array}{c}881 \mathrm{~B} \\
13\end{array}$ & $\begin{array}{c}881 \mathrm{~B} \\
13\end{array}$ & $\begin{array}{c}881 \mathrm{~B} \\
13\end{array}$ & $\begin{array}{c}881 B \\
14\end{array}$ & $\begin{array}{c}881 \mathrm{~B} \\
14\end{array}$ \\
\hline $\begin{array}{l}\mathrm{SiO}_{2} \\
\mathrm{Al}_{2} \mathrm{O}_{3} \\
\mathrm{FeO}^{*} \\
\mathrm{CaO} \\
\mathrm{BaO} \\
\mathrm{K}_{2} \mathrm{O} \\
\mathrm{Na}_{2} \mathrm{O}\end{array}$ & $\begin{array}{r}56.98 \\
27.33 \\
0.29 \\
8.39 \\
0.27 \\
0.28 \\
6.73\end{array}$ & $\begin{array}{r}53.07 \\
29.54 \\
0.59 \\
11.65 \\
0.28 \\
0.19 \\
4.97\end{array}$ & $\begin{array}{r}55.66 \\
28.14 \\
0.36 \\
9.59 \\
0.27 \\
0.20 \\
6.06\end{array}$ & $\begin{array}{r}56.11 \\
27.72 \\
0.42 \\
9.04 \\
0.27 \\
0.19 \\
6.52\end{array}$ & $\begin{array}{r}51.42 \\
30.79 \\
0.68 \\
13.09 \\
0.28 \\
0.15 \\
3.91\end{array}$ & $\begin{array}{r}44.83 \\
35.07 \\
0.64 \\
18.37 \\
0.27 \\
0.15 \\
0.94\end{array}$ & $\begin{array}{r}54.21 \\
29.34 \\
0.18 \\
11.10 \\
0.27 \\
0.09 \\
5.08\end{array}$ & $\begin{array}{r}53.81 \\
29.71 \\
0.15 \\
10.74 \\
0.27 \\
0.23 \\
5.53\end{array}$ & $\begin{array}{r}57.01 \\
27.14 \\
0.39 \\
8.69 \\
0.27 \\
0.37 \\
6.40\end{array}$ & $\begin{array}{r}59.39 \\
25.64 \\
0.26 \\
6.47 \\
0.27 \\
0.47 \\
7.77\end{array}$ & $\begin{array}{r}47.81 \\
33.07 \\
0.63 \\
16.01 \\
0.28 \\
0.14 \\
2.36\end{array}$ & $\begin{array}{r}54.55 \\
28.93 \\
0.26 \\
10.35 \\
0.27 \\
0.18 \\
5.73\end{array}$ & $\begin{array}{r}60.16 \\
25.00 \\
0.23 \\
5.55 \\
0.26 \\
0.32 \\
8.76\end{array}$ & $\begin{array}{r}48.96 \\
32.74 \\
0.43 \\
15.29 \\
0.27 \\
0.08 \\
2.49\end{array}$ & $\begin{array}{r}45.50 \\
34.92 \\
0.79 \\
17.78 \\
0.28 \\
0.07 \\
1.02\end{array}$ \\
\hline $\begin{array}{l}\text { Hole: } \\
\text { UNE number: }\end{array}$ & $\begin{array}{c}881 \mathrm{~B} \\
14\end{array}$ & $\begin{array}{c}881 \mathrm{~B} \\
15\end{array}$ & $\begin{array}{c}881 \mathrm{~B} \\
15\end{array}$ & $\begin{array}{c}881 \mathrm{~B} \\
16\end{array}$ & $\begin{array}{c}881 B \\
16 \\
\end{array}$ & $\begin{array}{c}881 \mathrm{~B} \\
16\end{array}$ & $\begin{array}{c}881 \mathrm{~B} \\
16\end{array}$ & $\begin{array}{c}881 \mathrm{~B} \\
16\end{array}$ & $\begin{array}{c}881 \mathrm{~B} \\
16\end{array}$ & $\begin{array}{l}881 \mathrm{~B} \\
22\end{array}$ & $\begin{array}{c}881 \mathrm{~B} \\
22\end{array}$ & $\begin{array}{c}881 \mathrm{~B} \\
23\end{array}$ & $\begin{array}{c}881 \mathrm{~B} \\
24\end{array}$ & $\begin{array}{c}881 \mathrm{~B} \\
24\end{array}$ & $\begin{array}{c}881 \mathrm{~B} \\
24\end{array}$ \\
\hline $\begin{array}{l}\mathrm{SiO}_{2} \\
\mathrm{Al}_{2} \mathrm{O}_{3} \\
\mathrm{FeO}^{*} \\
\mathrm{CaO} \\
\mathrm{BaO} \\
\mathrm{K}_{2} \mathrm{O} \\
\mathrm{Na}_{2} \mathrm{O}\end{array}$ & $\begin{array}{r}51.27 \\
30.77 \\
0.74 \\
13.24 \\
0.27 \\
0.16 \\
3.80\end{array}$ & $\begin{array}{r}49.81 \\
31.74 \\
0.68 \\
13.86 \\
0.27 \\
0.27 \\
3.64\end{array}$ & $\begin{array}{r}56.72 \\
27.38 \\
0.32 \\
8.66 \\
0.27 \\
0.29 \\
6.64\end{array}$ & $\begin{array}{r}46.26 \\
34.09 \\
0.65 \\
17.21 \\
0.27 \\
0.15 \\
1.64\end{array}$ & $\begin{array}{r}54.36 \\
29.12 \\
0.37 \\
10.67 \\
0.27 \\
0.07 \\
5.42\end{array}$ & $\begin{array}{r}49.71 \\
32.05 \\
0.57 \\
14.37 \\
0.27 \\
0.11 \\
3.18\end{array}$ & $\begin{array}{r}52.25 \\
30.50 \\
0.58 \\
12.71 \\
0.27 \\
0.06 \\
3.95\end{array}$ & $\begin{array}{r}49.90 \\
32.00 \\
0.44 \\
13.99 \\
0.27 \\
0.09 \\
3.58\end{array}$ & $\begin{array}{r}53.06 \\
29.64 \\
0.55 \\
11.80 \\
0.27 \\
0.16 \\
4.80\end{array}$ & $\begin{array}{r}57.44 \\
26.63 \\
0.62 \\
8.35 \\
0.27 \\
0.27 \\
6.67\end{array}$ & $\begin{array}{r}45.19 \\
34.91 \\
0.65 \\
17.78 \\
0.29 \\
0.16 \\
1.30\end{array}$ & $\begin{array}{r}51.92 \\
30.00 \\
0.66 \\
12.70 \\
0.27 \\
0.21 \\
4.50\end{array}$ & $\begin{array}{r}50.83 \\
31.31 \\
0.55 \\
13.40 \\
0.27 \\
0.12 \\
3.78\end{array}$ & $\begin{array}{r}52.05 \\
30.48 \\
0.57 \\
12.48 \\
0.27 \\
0.18 \\
4.25\end{array}$ & $\begin{array}{r}49.23 \\
31.76 \\
0.96 \\
14.82 \\
0.27 \\
0.26 \\
2.97\end{array}$ \\
\hline $\begin{array}{l}\text { Hole: } \\
\text { UNE number: }\end{array}$ & $\begin{array}{c}881 \mathrm{~B} \\
27\end{array}$ & $\begin{array}{c}881 \mathrm{~B} \\
28\end{array}$ & $\begin{array}{c}881 \mathrm{~B} \\
29\end{array}$ & $\begin{array}{c}881 \mathrm{~B} \\
29\end{array}$ & $\begin{array}{c}881 \mathrm{~B} \\
29\end{array}$ & $\begin{array}{c}881 \mathrm{~B} \\
29\end{array}$ & $\begin{array}{c}881 \mathrm{~B} \\
30\end{array}$ & $\begin{array}{c}881 \mathrm{~B} \\
30\end{array}$ & $\begin{array}{c}881 \mathrm{~B} \\
31\end{array}$ & $\begin{array}{c}881 \mathrm{~B} \\
33\end{array}$ & $\begin{array}{c}881 \mathrm{~B} \\
33\end{array}$ & $\begin{array}{c}881 \mathrm{~B} \\
33\end{array}$ & $\begin{array}{c}881 \mathrm{IB} \\
34\end{array}$ & $\begin{array}{c}881 \mathrm{~B} \\
34\end{array}$ & $\begin{array}{c}881 \mathrm{~B} \\
34\end{array}$ \\
\hline $\begin{array}{l}\mathrm{SiO}_{2} \\
\mathrm{Al}_{2} \mathrm{O}_{3} \\
\mathrm{FeO}^{*} \\
\mathrm{CaO} \\
\mathrm{BaO} \\
\mathrm{K}_{2} \mathrm{O} \\
\mathrm{Na}_{2} \mathrm{O}\end{array}$ & $\begin{array}{r}56.14 \\
27.73 \\
0.27 \\
9.41 \\
0.26 \\
0.24 \\
6.20\end{array}$ & $\begin{array}{r}63.32 \\
21.41 \\
2.05 \\
5.58 \\
0.30 \\
0.95 \\
6.38\end{array}$ & $\begin{array}{r}55.56 \\
28.61 \\
0.15 \\
9.65 \\
0.28 \\
0.39 \\
5.81\end{array}$ & $\begin{array}{r}53.21 \\
29.25 \\
0.78 \\
11.42 \\
0.27 \\
0.42 \\
4.91\end{array}$ & $\begin{array}{r}56.71 \\
27.41 \\
0.41 \\
9.15 \\
0.27 \\
0.13 \\
6.20\end{array}$ & $\begin{array}{r}53.54 \\
28.96 \\
0.88 \\
11.19 \\
0.26 \\
0.21 \\
5.22\end{array}$ & $\begin{array}{r}55.31 \\
28.08 \\
0.65 \\
9.88 \\
0.27 \\
0.36 \\
5.71\end{array}$ & $\begin{array}{r}55.30 \\
28.01 \\
0.56 \\
10.11 \\
0.27 \\
0.30 \\
5.71\end{array}$ & $\begin{array}{r}51.24 \\
30.97 \\
0.52 \\
13.66 \\
0.27 \\
0.06 \\
3.61\end{array}$ & $\begin{array}{r}50.09 \\
31.35 \\
0.96 \\
14.03 \\
0.27 \\
0.14 \\
3.42\end{array}$ & $\begin{array}{r}50.24 \\
31.08 \\
1.03 \\
13.75 \\
0.26 \\
0.23 \\
3.67\end{array}$ & $\begin{array}{r}51.62 \\
30.16 \\
1.07 \\
12.62 \\
0.27 \\
0.20 \\
4.33\end{array}$ & $\begin{array}{r}44.44 \\
35.38 \\
0.79 \\
18.20 \\
0.27 \\
0.08 \\
1.10\end{array}$ & $\begin{array}{r}55.62 \\
27.92 \\
0.40 \\
9.91 \\
0.27 \\
0.24 \\
5.95\end{array}$ & $\begin{array}{r}46.86 \\
33.85 \\
0.68 \\
16.61 \\
0.27 \\
0.12 \\
1.88\end{array}$ \\
\hline $\begin{array}{l}\text { Hole: } \\
\text { UNE number: }\end{array}$ & $\begin{array}{c}881 \mathrm{~B} \\
42\end{array}$ & $\begin{array}{c}881 \mathrm{~B} \\
42\end{array}$ & $\begin{array}{c}881 \mathrm{~B} \\
42\end{array}$ & $\begin{array}{c}881 \mathrm{~B} \\
44\end{array}$ & $\begin{array}{c}881 \mathrm{~B} \\
44\end{array}$ & $\begin{array}{c}881 \mathrm{~B} \\
44\end{array}$ & $\begin{array}{c}881 \mathrm{~B} \\
45\end{array}$ & $\begin{array}{c}881 \mathrm{~B} \\
45\end{array}$ & $\begin{array}{c}881 \mathrm{~B} \\
45\end{array}$ & $\begin{array}{c}881 \mathrm{~B} \\
45\end{array}$ & $\begin{array}{c}881 \mathrm{~B} \\
46\end{array}$ & $\begin{array}{c}881 \mathrm{~B} \\
46\end{array}$ & $\begin{array}{c}881 \mathrm{~B} \\
46\end{array}$ & $\begin{array}{c}881 \mathrm{~B} \\
47\end{array}$ & $\begin{array}{c}881 \mathrm{~B} \\
47\end{array}$ \\
\hline $\begin{array}{l}\mathrm{SiO}_{2} \\
\mathrm{Al}_{2} \mathrm{O}_{3} \\
\mathrm{FeO}^{*} \\
\mathrm{CaO} \\
\mathrm{BaO} \\
\mathrm{K}_{2} \mathrm{O} \\
\mathrm{Na}_{2} \mathrm{O}\end{array}$ & $\begin{array}{r}47.32 \\
33.49 \\
0.76 \\
16.12 \\
0.26 \\
0.14 \\
2.16\end{array}$ & $\begin{array}{r}44.04 \\
35.85 \\
0.70 \\
18.54 \\
0.26 \\
0.10 \\
0.78\end{array}$ & $\begin{array}{r}48.31 \\
32.81 \\
0.82 \\
15.50 \\
0.27 \\
0.10 \\
2.46\end{array}$ & $\begin{array}{r}58.25 \\
26.44 \\
0.38 \\
7.71 \\
0.27 \\
0.44 \\
6.78\end{array}$ & $\begin{array}{r}54.11 \\
29.51 \\
0.15 \\
10.69 \\
0.27 \\
0.16 \\
5.53\end{array}$ & $\begin{array}{r}56.00 \\
27.35 \\
1.19 \\
10.27 \\
0.28 \\
0.61 \\
4.59\end{array}$ & $\begin{array}{r}50.74 \\
31.03 \\
0.73 \\
13.61 \\
0.27 \\
0.16 \\
3.73\end{array}$ & $\begin{array}{r}55.07 \\
27.10 \\
1.79 \\
10.28 \\
0.30 \\
0.36 \\
5.10\end{array}$ & $\begin{array}{r}49.43 \\
32.05 \\
0.76 \\
14.67 \\
0.29 \\
0.07 \\
3.09\end{array}$ & $\begin{array}{r}44.72 \\
35.65 \\
0.69 \\
17.74 \\
0.28 \\
0.06 \\
1.13\end{array}$ & $\begin{array}{r}50.85 \\
31.12 \\
0.57 \\
13.35 \\
0.27 \\
0.16 \\
3.96\end{array}$ & $\begin{array}{r}49.41 \\
32.09 \\
0.73 \\
14.50 \\
0.27 \\
0.19 \\
3.09\end{array}$ & $\begin{array}{r}55.78 \\
27.79 \\
0.46 \\
9.21 \\
0.25 \\
0.39 \\
6.37\end{array}$ & $\begin{array}{r}51.33 \\
30.32 \\
1.12 \\
13.14 \\
0.27 \\
0.32 \\
3.78\end{array}$ & $\begin{array}{r}47.04 \\
33.87 \\
0.66 \\
16.32 \\
0.27 \\
0.11 \\
1.98\end{array}$ \\
\hline
\end{tabular}

Notes: UNE number refers to the ash layer number analyzed at UNE (see Table 1). All totals are normalized to $100 \%$, volatile free. All Fe reported as FeO*. 
Table 13. Representative analyses of plagioclase from Hole 882A.

\begin{tabular}{|c|c|c|c|c|c|c|c|c|c|c|c|}
\hline UNE number: & 52 & 52 & 55 & 59 & 60 & 60 & 61 & 61 & 63 & 63 & 66 \\
\hline $\begin{array}{l}\mathrm{SiO}_{2} \\
\mathrm{Al}_{2} \mathrm{O}_{3} \\
\mathrm{FeO}^{*} \\
\mathrm{CaO} \\
\mathrm{BaO} \\
\mathrm{K}_{2} \mathrm{O} \\
\mathrm{Na}_{2} \mathrm{O}\end{array}$ & $\begin{array}{r}52.21 \\
30.22 \\
0.50 \\
12.20 \\
0.27 \\
0.26 \\
4.61\end{array}$ & $\begin{array}{r}56.32 \\
27.40 \\
0.56 \\
8.94 \\
0.27 \\
0.52 \\
6.25\end{array}$ & $\begin{array}{r}56.13 \\
27.70 \\
0.40 \\
9.16 \\
0.27 \\
0.50 \\
6.11\end{array}$ & $\begin{array}{r}45.86 \\
35.15 \\
0.14 \\
17.19 \\
0.26 \\
0.14 \\
1.66\end{array}$ & $\begin{array}{r}57.71 \\
26.50 \\
0.58 \\
7.83 \\
0.27 \\
0.34 \\
7.06\end{array}$ & $\begin{array}{r}57.50 \\
26.78 \\
0.34 \\
8.39 \\
0.27 \\
0.28 \\
6.71\end{array}$ & $\begin{array}{r}53.45 \\
29.33 \\
0.61 \\
11.31 \\
0.27 \\
0.14 \\
5.18\end{array}$ & $\begin{array}{r}55.19 \\
28.48 \\
0.40 \\
10.16 \\
0.27 \\
0.23 \\
5.54\end{array}$ & $\begin{array}{r}47.60 \\
33.24 \\
0.89 \\
16.11 \\
0.27 \\
0.14 \\
2.00\end{array}$ & $\begin{array}{r}48.77 \\
32.65 \\
0.72 \\
14.92 \\
0.27 \\
0.23 \\
2.71\end{array}$ & $\begin{array}{r}47.63 \\
33.10 \\
0.95 \\
15.53 \\
0.26 \\
0.22 \\
2.56\end{array}$ \\
\hline UNE number: & 66 & 67 & 67 & 70 & 70 & 70 & 70 & 72 & 72 & 73 & 73 \\
\hline $\begin{array}{l}\mathrm{SiO}_{2} \\
\mathrm{Al}_{2} \mathrm{O}_{3} \\
\mathrm{FeO}^{*} \\
\mathrm{CaO} \\
\mathrm{BaO} \\
\mathrm{K}_{2} \mathrm{O} \\
\mathrm{Na}_{2} \mathrm{O}\end{array}$ & $\begin{array}{r}46.21 \\
34.10 \\
0.74 \\
16.91 \\
0.27 \\
0.19 \\
1.86\end{array}$ & $\begin{array}{r}54.78 \\
28.98 \\
0.37 \\
10.28 \\
0.26 \\
0.19 \\
5.42\end{array}$ & $\begin{array}{r}47.56 \\
33.31 \\
0.74 \\
15.69 \\
0.27 \\
0.16 \\
2.55\end{array}$ & $\begin{array}{r}52.46 \\
30.40 \\
0.53 \\
12.00 \\
0.26 \\
0.10 \\
4.51\end{array}$ & $\begin{array}{r}57.48 \\
26.08 \\
1.02 \\
8.64 \\
0.26 \\
0.50 \\
6.28\end{array}$ & $\begin{array}{r}52.89 \\
29.14 \\
1.29 \\
12.04 \\
0.27 \\
0.22 \\
4.42\end{array}$ & $\begin{array}{r}52.06 \\
30.28 \\
0.63 \\
12.14 \\
0.26 \\
0.32 \\
4.56\end{array}$ & $\begin{array}{r}59.43 \\
22.04 \\
3.63 \\
4.67 \\
1.01 \\
2.11 \\
7.11\end{array}$ & $\begin{array}{r}54.22 \\
29.07 \\
0.61 \\
10.75 \\
0.27 \\
0.24 \\
5.11\end{array}$ & $\begin{array}{r}55.12 \\
28.46 \\
0.49 \\
10.15 \\
0.26 \\
0.21 \\
5.56\end{array}$ & $\begin{array}{r}55.12 \\
28.46 \\
0.49 \\
10.15 \\
0.26 \\
0.21 \\
5.56\end{array}$ \\
\hline UNE number: & 74 & 74 & 74 & 76 & 76 & 76 & 78 & 78 & 78 & 95 & \\
\hline $\begin{array}{l}\mathrm{SiO}_{2} \\
\mathrm{Al}_{2} \mathrm{O}_{3} \\
\mathrm{FeO}^{*} \\
\mathrm{CaO} \\
\mathrm{BaO} \\
\mathrm{K}_{2} \mathrm{O} \\
\mathrm{Na}_{2} \mathrm{O}\end{array}$ & $\begin{array}{r}46.02 \\
34.12 \\
1.08 \\
16.90 \\
0.27 \\
0.14 \\
1.72\end{array}$ & $\begin{array}{r}44.53 \\
35.41 \\
0.95 \\
17.98 \\
0.27 \\
0.10 \\
1.04\end{array}$ & $\begin{array}{r}50.80 \\
31.18 \\
0.86 \\
13.63 \\
0.26 \\
0.08 \\
3.44\end{array}$ & $\begin{array}{r}48.15 \\
32.99 \\
0.78 \\
15.69 \\
0.27 \\
0.12 \\
2.28\end{array}$ & $\begin{array}{r}47.05 \\
33.47 \\
1.00 \\
16.31 \\
0.27 \\
0.19 \\
1.99\end{array}$ & $\begin{array}{r}44.17 \\
36.07 \\
0.57 \\
18.79 \\
0.28 \\
0.06 \\
0.39\end{array}$ & $\begin{array}{r}46.76 \\
34.06 \\
0.56 \\
16.58 \\
0.27 \\
0.11 \\
1.93\end{array}$ & $\begin{array}{r}53.01 \\
29.36 \\
0.79 \\
11.51 \\
0.26 \\
0.34 \\
4.99\end{array}$ & $\begin{array}{r}53.61 \\
27.50 \\
1.71 \\
12.43 \\
0.27 \\
0.45 \\
4.28\end{array}$ & $\begin{array}{r}52.58 \\
30.34 \\
0.39 \\
12.04 \\
0.27 \\
0.23 \\
4.42\end{array}$ & \\
\hline
\end{tabular}

Notes: UNE number refers to the ash layer number analyzed at UNE (see Table 2). All totals are normalized to $100 \%$, volatile free. All Fe reported as FeO*.
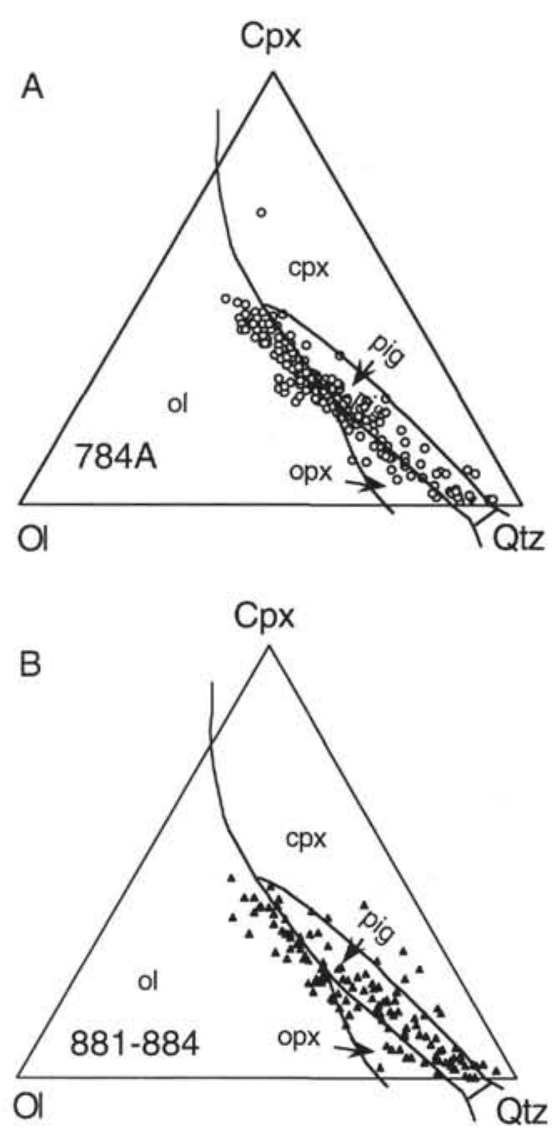

Figure 13. Ash composition projections from plagioclase. A. ODP Leg 125 Hole 784A (Izu-Bonin forearc site) ash compositions in terms of oxygenweighted, molar proportions in the system: $\mathrm{Ol}=$ olivine; $\mathrm{Cpx}=$ clinopyroxene; and $\mathrm{Qtz}=\mathrm{SiO}_{2}$. The atmospheric pressure primary liquidus phase fields for olivine (ol), clinopyroxene (cpx), orthopyroxene (opx), pigeonite (pig), and cotectics are from Grove et al. (1982). B. Sites 881-884 ash compositions, abbreviations as above.

\section{REFERENCES ${ }^{*}$}

Arculus, R.J., and Bloomfield, A.L., 1992. Major-element geochemistry of ashes from Sites 782, 784, and 786 in the Bonin forearc. In Fryer, P., Pearce, J.A., Stokking, L.B., et al., Proc. ODP, Sci. Results, 125: College Station, TX (Ocean Drilling Program), 277-292.

Arculus, R.J., Gill, J.B., Cambray, H., Chen, W., and Stern, R.J., 1995. Geochemical evolution of arc systems in the western Pacific: the ash and turbidite record recovered by drilling. In Taylor, B., and Natland, J. (Eds.), The ODP in the Western Pacific Convergent Margins. Am. Geophys. Union, 45-65.

Baker, P.E., 1968. Comparative volcanology and petrology of the Atlantic island arcs. Bull. Volcanol., 32:189-206.

Baker, P.E., Coltorti, M., Briqueu, L., Hasenaka, T., and Condliffe, E., 1994. Volcanic ash layers from Sites 828, 830, 831, 832, and 833, New Hebrides island arc. In Greene, H.G., Collot, J.-Y., Stokking, L.B., et al., Proc. ODP, Sci. Results, 134: College Station, TX (Ocean Drilling Program), 403-412.

Ballhaus, C., 1993. Redox states of lithospheric and asthenospheric upper mantle. Contrib. Mineral. Petrol., 114:331-348.

Cambray, H., 1991. Etude de téphra des sédiments marins: comparaison entre les épisodes d'activité volcanique et l'évolution tectonique [Ph.D. thesis]. Univ. Pierre et Marie Curie, Paris VI.

Carey, S., and Sigurdsson, H., 1980. The Roseau ash: deep-sea tephra deposits from a major eruption on Dominica, Lesser Antilles arc. J. Volcanol. Geotherm. Res., 7:67-86.

Carmichael, I.S.E., 1967. The iron-titanium oxides of salic volcanic rocks and their associated ferromagnesian silicates. Contrib. Mineral. Petrol., 14:36-64.

Creager, J.S., Scholl, D.W., et al., 1973. Init. Repts. DSDP, 19: Washington (U.S. Govt. Printing Office).

Erlich, E.N., 1971. Recent movements and Quaternary volcanic activity within the Kamchatka territory. Pac. Geol., 6:23-39.

Fedorchuk, A., Kepezhinskas, P., Defant, M.J., Maury, R.C., and Cotten, J., 1993. Two types of granitic melts related to amalgamation of the Ganal metamorphic terrane, Kamchatka, Russia: implications for crustal evolution during collision of island arc systems. Eos, 74:681.

Fedotov, S.A., and Masurenkov, Yu.P., 1991. Active Volcanoes of Kamchatka: Moscow (Nauka).

\footnotetext{
- Abbreviations for names of organizations and publications in ODP reference lists follow the style given in Chemical Abstracts Service Source Index (published by American Chemical Society).
} 
Fujioka, K., Matsuo, Y., Nishimura, A., Koyama, M., and Rodolfo, K.S., 1992. Tephras of the Izu-Bonin forearc (Sites 787, 792, and 793). In Taylor, B., Fujioka, K., et al., Proc. ODP, Sci. Results, 126: College Station, TX (Ocean Drilling Program), 47-74.

Ghiorso, M.S., and Sack, R.O., 1991. Fe-Ti oxide geothermometry: thermodynamic formulation and the estimation of intensive variables in silicic magmas. Contrib. Mineral. Petrol., 108:485-510.

Gill, J.B., 1970. Geochemistry of Viti Levu, Fiji, and its evolution as an island arc. Contrib. Mineral. Petrol., 27:179-203. (Springer)

Gill, J.B., Hiscott, R.N., and Vidal, P., 1994. Turbidite geochemistry and evolution of the Izu-Bonin arc and continents. Lithos, 33:135-168.

Gnibidenko, H.S., Gorbachev, S.Z., Lebedev, M.M., and Marakhanov, V.I., 1972. Geology and deep structure of Kamchatka Peninsula. Pac. Geol., 7:1-29.

Grove, T.L., Gerlach, D.C., and Sando, T.W., 1982. Origin of calc-alkaline series lavas at Medicine Lake Volcano by fractionation, assimilation and mixing. Contrib. Mineral. Petrol., 80:160-182.

Heath, G.R., Burckle, L.H., et al., 1985. Init. Repts, DSDP, 86: Washington (U.S. Govt. Printing Office).

Huang, T.C., 1980. A volcanic sedimentation model: implications of processes and responses of deep-sea ashes. Mar. Geol., 38:103-122.

Hussong, D.M., and Uyeda, S., 1982. Tectonic processes and the history of the Mariana Arc: a synthesis of the results of Deep Sea Drilling Project Leg 60. In Hussong, D.M., Uyeda, S., et al., Init. Repts. DSDP, 60: Washington (U.S. Govt. Printing Office), 909-929.

Jolivet, L., Cadet, J.-P., and Lalevée, F., 1988. Mesozoic evolution of Northeast Asia and the collision of the Okhotsk microcontinent. Tectonophysics, 149:89-109.

Karig, D.E., 1974. Evolution of arc systems in the western Pacific. Annu. Rev, Earth Planet. Sci., 2:51-75.

1983. Temporal relationships between back-arc basin formation and arc volcanism with special reference to the Philippine Sea. In Hayes, D.E. (Ed.), The Tectonic and Geological Evolution of Southeast Asian Seas and Islands (Pt. 2): Geophys. Monogr., Am. Geophys. Union., 27:318-325.

Kennett, J.P., McBirney, A.R., and Thunell, R.C., 1977. Episodes of Cenozoic volcanism in the Circum-Pacific region. J. Volcanol. Geotherm. Res., 2:145-163.

Kennett, J.P., and Thunnell, R.C., 1977. On explosive Cenozoic volcanism and climatic implications. Science, 196:1231-1234.

Kersting, A.B., and Arculus, R.J., 1994. Klyuchevskoy volcano, Kamchatka, Russia: the role of high-flux, recharged, tapped and fractionated magma chamber(s) in the genesis of high- $\mathrm{Al}_{2} \mathrm{O}_{3}$ from high-MgO basalt. J. Petrol., $35: 1-42$.

Kimura, G., and Tamaki, K., 1985. Tectonic framework of the Kuril arc since its initiation. In Nasu, N. (Ed.), Formation of Active Margins: Tokyo (Terra Publ.), 641-676.

Kir'yanov, V.Y., and Rozhkov, G.F., 1990. Grain-size distribution of Recent tephra deposited by the largest explosive eruptions of the Kamchatka volcanoes. Volc. Seis., 11:305-324.

Kir'yanov, V.Y., Zharinov, S.E., and Perepelov, A.B., 1990. Possible geochemical differences of east Kamchatkan volcanic ashes. Volc. Seis., 9:320-328.

Klein, E.M., and Langmuir, C.H., 1987. Global correlations of ocean ridge basalt chemistry with axial depth and crustal thickness. J. Geophys. Res., 92:8089-8115.

Kuno, H., 1959. Origin of Cenozoic petrographic provinces of Japan and surrounding areas. Bull. Volcanol., 20:37-76.

Kyle, P.R., Jezek, P.A., Mosley-Thompson, E., and Thompson, L.G., 1981. Tephra layers in the Byrd station ice core and the dome C ice core, Antarctica, and their climatic importance. J. Volcanol. Geotherm. Res., 11:29-39.

Leonova, L.L., 1979. Geochemistry of the Quaternary and Recent volcanic rocks in the Kurile islands and Kamchatka. Geokhimiya, 2:179-197.

Lonsdale, P., 1988. Paleogene history of the Kula plate: offshore evidence and onshore implications. Geol. Soc. Am. Bull., 100:733-754.

Miyashiro, A., 1974. Volcanic rock series in island arcs and active continental margins. Am. J. Sci., 274:321-355.

Moroz, Y.F., 1988. The deep structure of East Kamchatka from magnetotelluric data. Volc. Seis., 6:769-779.

Natland, J.H., 1993. Volcanic ash and pumice at Shatsky Rise: sources, mechanisms of transport, and bearing on atmospheric circulation. In
Natland, J.H., Storms, M.A., et al., Proc. ODP, Sci. Results, 132: College Station, TX (Ocean Drilling Program), 57-66.

Ninkovich, D., and Donn, W.L., 1976. Explosive Cenozoic volcanism and climatic interpretations. Science, 194:899-906.

Oyama, M., and Takehara, H., 1967. Revised Standard Soil Colour Charts: Japan (Res. Counc. Agric. Forest. Fish., Minist. Agric. Forest.).

Pearce, J.A., and Parkinson, I.J., 1993. Trace element models for mantle melting: application to volcanic arc petrogenesis. In Pritchard, H.M. Alabaster, T., Harris, N.B.W., and Neary, C.R. (Eds.), Magmatic Processes and Plate Tectonics. Geol. Soc. Spec. Publ. London, 76:373-403.

Plank, T., and Langmuir, C.H., 1988. An evaluation of the global variations in the major element chemistry of arc basalts. Earth Planet. Sci. Lett., 90:349-370.

Pouclet, A., Fujioka, K., Furuta, T., and Ogihara, S., 1992. Data report: Geochemistry and mineralogy of ash layers from Legs 127 and 128 in the Japan Sea. In Tamaki, K., Suyehiro, K., Allan, J., McWilliams, M., et al. Proc, ODP, Sci. Results, 127/128 (Pt. 2): College Station, TX (Ocean Drilling Program), 1373-1393.

Pouclet, A., Pubellier, M., and Spadea, P., 1991. Volcanic ash from Celebes and Sulu Sea basins off the Philippines (Leg 124): petrography and geochemistry. In Silver, E.A., Rangin, C., von Breymann, M.T., et al., Proc. ODP, Sci. Results, 124: College Station, TX (Ocean Drilling Program), $467-488$.

Pouclet, A., and Scott, S.D., 1992. Volcanic ash layers in the Japan Sea: tephrochronology of Sites 798 and 799. In Tamaki, K., Suyehiro, K., Allan, J., McWilliams, M., et al., Proc. ODP, Sci. Results, 127/128 (Pt. 2): College Station, TX (Ocean Drilling Program), 791-803.

Rea, D.K., Basov, I.A., Janecek, T.R., Palmer-Julson, A., et al., 1993. Proc ODP, Init. Repts., 145: College Station, TX (Ocean Drilling Program).

Rea, D.K., and Duncan, R.A., 1986. North Pacific Plate convergence: a quantitative record of the past 140 m.y. Geology, 14:373-376.

Rea, D.K., and Thiede, J., 1981. Mesozoic and Cenozoic mass accumulation rates of the major sediment components in the Nauru Basin, Western Equatorial Pacific. In Larson, R.L., Schlanger, S.O., et al., Init. Repts. DSDP, 61: Washington (U.S. Govt. Printing Office), 549-555.

Rodolfo, K.S., Solidum, R.U., Nishimura, A., Matsuo, Y., and Fujioka, K., 1992. Major-oxide stratigraphy of glass shards in volcanic ash layers of the Izu-Bonin Arc-backarc sites (Sites $788 / 789$ and 790/791). In Taylor, B., Fujioka, K., et al., Proc. ODP, Sci. Results, 126: College Station, TX (Ocean Drilling Program), 505-517.

Rose, W.I., and Chesner, C.A., 1987. Dispersal of ash in the great Toba eruption, $75 \mathrm{ka}$. Geology, 15:913-917.

Scheidegger, K.F., Corliss, J.B., Jezek, P.A., and Ninkovich, D., 1980. Composition of deep-sea ash layers derived from north Pacific volcanic arcs: variations in time and space. J. Volcanol. Geotherm. Res., 7:107-137.

Scott, R., and Kroenke, L.W., 1980. Evolution of back arc spreading and arc volcanism in the Philippine Sea: interpretation of Leg 59 DSDP results. In Hayes, D.E. (Ed.), The Tectonic and Geologic Evolution of Southeast Asian Seas and Islands. Geophys. Monogr., Am. Geophys. Union, 23:283291.

Shantser, A.E., and Shapiro, M.N., 1988. Evolution of volcanic zones in Kamchatka and tectonic development of the active continental margin. Volc. Seis., 6:195-217.

Sparks, R.S.J., and Walker, G.P.L., 1977. The significance of vitric enriched air-fall ashes associated with crystal-enriched ignimbrites. J. Volcanol. Geotherm. Res., 2:329-341.

Spiegelman, M., and McKenzie, D.P., 1987. Simple 2-D models for melt extraction at mid-ocean ridges and island arcs. Earth Planet. Sci. Lett., $83: 137-152$.

Sugimura, A., 1960. Zonal arrangement of some geophysical and petrological features in Japan and its environs. J. Fac. Sci., Univ. Tokyo, 12:133-153.

Sun, S.-S., and McDonough, W.F., 1989. Chemical and isotopic systematics of oceanic basalts: implications for mantle composition and processes. In Saunders, A.D., and Norry, M.J. (Eds.), Magmatism in the Ocean Basins. Geol. Soc. Spec. Publ. London, 42:313-345.

Taylor, B., 1992. Rifting and the volcanic-tectonic evolution of the Izu-BoninMariana Arc. In Taylor, B., Fujioka, K., et al., Proc. ODP, Sci. Results, 126: College Station, TX (Ocean Drilling Program), 627-651.

Taylor, S.R., 1967. The origin and growth of continents, Tectonophysics, $4: 17-34$

Vallier, T.L., Dean, W.E., Rea, D.K., and Thiede, J., 1983. Geologic evolution of Hess Rise, central North Pacific Ocean. Geol. Soc. Am. Bull., 94:12891307. 
Walker, G.P.L., 1980. The Taupo pumice: product of the most powerful known (ultraplinian) eruption? J. Volcanol. Geotherm. Res., 8:69-94.

Watson, B.F., and Fujita, K., 1985. Tectonic evolution of Kamchatka and the Sea of Okhotsk and implications for the Pacific Basin. In Howell, D.G. (Ed.), Tectonostratigraphic Terranes: Houston (Circum-Pac. Counc. Energy Miner. Resour.), 333-348.

Zhuravlev, D.Z., Tsvetkov, A.A., Zhuravlev, A.Z., Gladkov, N.G., and Chernyshev, I.V., 1985. Petrogenetic significance of lateral variations in neo- dymium and strontium isotope ratios in Quaternary lavas of the Kurile island arc. Geokhimiya, 12:1723-1736.

Date of initial receipt: 26 April 1994

Date of acceptance: 17 October 1994

Ms 145SR-126

Table 14. Representative analyses of spinel and ilmenite.

\begin{tabular}{|c|c|c|c|c|c|c|c|c|c|c|c|c|c|}
\hline \multicolumn{14}{|c|}{ Spinel } \\
\hline $\begin{array}{l}\text { Hole: } \\
\text { UNE number: }\end{array}$ & $\begin{array}{c}881 \mathrm{~B} \\
11\end{array}$ & $\begin{array}{c}881 \mathrm{~B} \\
11\end{array}$ & $\begin{array}{c}881 \mathrm{~B} \\
11\end{array}$ & $\begin{array}{c}881 \mathrm{~B} \\
11\end{array}$ & $\begin{array}{c}881 \mathrm{~B} \\
11\end{array}$ & $\begin{array}{c}881 \mathrm{~B} \\
13\end{array}$ & $\begin{array}{c}881 \mathrm{~B} \\
13\end{array}$ & $\begin{array}{c}881 \mathrm{~B} \\
13\end{array}$ & $\begin{array}{c}881 B \\
24\end{array}$ & $\begin{array}{c}881 \mathrm{~B} \\
24\end{array}$ & $\begin{array}{c}881 \mathrm{~B} \\
24\end{array}$ & $\begin{array}{l}881 \mathrm{~B} \\
25\end{array}$ & $\begin{array}{c}881 \mathrm{~B} \\
25\end{array}$ \\
\hline $\begin{array}{l}\mathrm{TiO}_{2} \\
\mathrm{Al}_{2} \mathrm{O}_{3} \\
\mathrm{Cr}_{2} \mathrm{O}_{3} \\
\mathrm{~V}_{2} \mathrm{O}_{3} \\
\mathrm{FeO}^{*} \\
\mathrm{NiO} \\
\mathrm{MnO} \\
\mathrm{MgO}\end{array}$ & $\begin{array}{r}2.84 \\
0.70 \\
0.13 \\
0.16 \\
90.59 \\
2.87 \\
1.42 \\
1.28\end{array}$ & $\begin{array}{r}6.89 \\
2.56 \\
0.14 \\
0.40 \\
88.37 \\
0.30 \\
0.56 \\
0.77\end{array}$ & $\begin{array}{r}6.96 \\
2.13 \\
0.13 \\
0.44 \\
88.09 \\
0.29 \\
0.58 \\
1.37\end{array}$ & $\begin{array}{r}7.07 \\
1.71 \\
0.14 \\
0.36 \\
88.98 \\
0.30 \\
0.74 \\
0.69\end{array}$ & $\begin{array}{r}7.09 \\
1.94 \\
0.13 \\
0.39 \\
88.45 \\
0.29 \\
0.63 \\
1.07\end{array}$ & $\begin{array}{r}4.48 \\
0.98 \\
0.13 \\
0.36 \\
92.45 \\
0.29 \\
1.15 \\
0.16\end{array}$ & $\begin{array}{r}5.56 \\
2.12 \\
0.13 \\
0.17 \\
89.36 \\
0.28 \\
0.89 \\
1.50\end{array}$ & $\begin{array}{r}9.45 \\
3.40 \\
0.13 \\
0.95 \\
81.48 \\
0.28 \\
4.07 \\
0.25\end{array}$ & $\begin{array}{r}3.22 \\
1.12 \\
0.13 \\
0.62 \\
93.87 \\
0.28 \\
0.21 \\
0.55\end{array}$ & $\begin{array}{r}13.15 \\
2.40 \\
0.13 \\
0.41 \\
81.73 \\
0.28 \\
0.49 \\
1.42\end{array}$ & $\begin{array}{r}13.33 \\
2.75 \\
0.13 \\
0.45 \\
80.85 \\
0.28 \\
0.58 \\
1.63\end{array}$ & $\begin{array}{r}9.60 \\
1.60 \\
0.13 \\
0.85 \\
86.55 \\
0.28 \\
0.35 \\
0.64\end{array}$ & $\begin{array}{r}15.37 \\
2.32 \\
0.14 \\
0.58 \\
78.79 \\
0.29 \\
0.62 \\
1.88\end{array}$ \\
\hline $\begin{array}{l}\text { Hole: } \\
\text { UNE number: }\end{array}$ & $\begin{array}{c}881 B \\
36\end{array}$ & $\begin{array}{c}881 \mathrm{~B} \\
36\end{array}$ & $\begin{array}{c}881 \mathrm{~B} \\
43\end{array}$ & $\begin{array}{c}881 \mathrm{~B} \\
47\end{array}$ & $\begin{array}{c}881 \mathrm{~B} \\
47\end{array}$ & $\begin{array}{c}882 \mathrm{~A} \\
52\end{array}$ & $\begin{array}{c}882 \mathrm{~A} \\
52\end{array}$ & $\begin{array}{c}882 \mathrm{~A} \\
53\end{array}$ & $\begin{array}{c}882 \mathrm{~A} \\
62\end{array}$ & $\begin{array}{c}882 \mathrm{~A} \\
62\end{array}$ & $\begin{array}{c}882 \mathrm{~A} \\
73 \\
\end{array}$ & $\begin{array}{c}882 \mathrm{~A} \\
73\end{array}$ & \\
\hline $\begin{array}{l}\mathrm{TiO}_{2} \\
\mathrm{Al}_{2} \mathrm{O}_{3} \\
\mathrm{Cr}_{2} \mathrm{O}_{3} \\
\mathrm{~V}_{2} \mathrm{O}_{3} \\
\mathrm{FeO}^{*} \\
\mathrm{NiO} \\
\mathrm{MnO} \\
\mathrm{MgO}\end{array}$ & $\begin{array}{r}6.87 \\
1.39 \\
0.14 \\
0.19 \\
88.80 \\
0.29 \\
0.81 \\
1.51\end{array}$ & $\begin{array}{r}11.88 \\
2.13 \\
0.13 \\
0.84 \\
84.35 \\
0.28 \\
0.22 \\
0.16\end{array}$ & $\begin{array}{r}15.17 \\
1.17 \\
0.13 \\
0.99 \\
81.53 \\
0.28 \\
0.35 \\
0.38\end{array}$ & $\begin{array}{r}13.06 \\
2.88 \\
0.13 \\
0.97 \\
80.84 \\
0.28 \\
0.37 \\
1.47\end{array}$ & $\begin{array}{r}16.30 \\
2.56 \\
0.13 \\
0.28 \\
78.75 \\
0.26 \\
0.67 \\
1.04\end{array}$ & $\begin{array}{r}11.15 \\
3.45 \\
0.24 \\
0.65 \\
80.25 \\
0.28 \\
0.49 \\
3.48\end{array}$ & $\begin{array}{r}11.68 \\
1.85 \\
0.13 \\
0.54 \\
82.54 \\
0.27 \\
0.56 \\
2.43\end{array}$ & $\begin{array}{r}11.57 \\
2.42 \\
0.13 \\
0.45 \\
82.90 \\
0.28 \\
0.62 \\
1.63\end{array}$ & $\begin{array}{r}10.42 \\
3.33 \\
0.13 \\
0.65 \\
81.72 \\
0.27 \\
0.40 \\
3.09\end{array}$ & $\begin{array}{r}11.32 \\
2.31 \\
0.14 \\
0.48 \\
82.55 \\
0.28 \\
0.54 \\
2.37\end{array}$ & $\begin{array}{r}11.49 \\
2.50 \\
0.13 \\
0.43 \\
83.18 \\
0.27 \\
0.40 \\
1.61\end{array}$ & $\begin{array}{r}11.51 \\
2.66 \\
0.13 \\
0.47 \\
82.79 \\
0.26 \\
0.47 \\
1.72\end{array}$ & \\
\hline \multicolumn{14}{|c|}{ Ilmenite } \\
\hline $\begin{array}{l}\text { Hỏle: } \\
\text { UNE number: }\end{array}$ & $\begin{array}{c}881 \mathrm{~B} \\
11\end{array}$ & $\begin{array}{c}881 \mathrm{~B} \\
13\end{array}$ & $\begin{array}{c}881 \mathrm{~B} \\
24\end{array}$ & $\begin{array}{c}881 \mathrm{~B} \\
25\end{array}$ & $\begin{array}{c}881 \mathrm{~B} \\
25\end{array}$ & $\begin{array}{c}881 \mathrm{~B} \\
36\end{array}$ & $\begin{array}{c}881 \mathrm{~B} \\
43\end{array}$ & $\begin{array}{c}882 \mathrm{~A} \\
52\end{array}$ & $\begin{array}{c}882 \mathrm{~A} \\
53\end{array}$ & $\begin{array}{c}882 \mathrm{~A} \\
53\end{array}$ & $\begin{array}{c}882 \mathrm{~A} \\
62 \\
\end{array}$ & $\begin{array}{c}882 \mathrm{~A} \\
73 \\
\end{array}$ & \\
\hline $\begin{array}{l}\mathrm{TiO}_{2} \\
\mathrm{Al}_{2} \mathrm{O}_{3} \\
\mathrm{Cr}_{2} \mathrm{O}_{3} \\
\mathrm{~V}_{2} \mathrm{O}_{3} \\
\mathrm{FeO}^{*} \\
\mathrm{NiO} \\
\mathrm{MnO} \\
\mathrm{MgO}\end{array}$ & $\begin{array}{r}45.15 \\
0.22 \\
0.29 \\
0.29 \\
50.50 \\
0.28 \\
1.61 \\
1.67\end{array}$ & $\begin{array}{r}47.58 \\
0.23 \\
0.13 \\
0.29 \\
48.03 \\
0.26 \\
0.86 \\
2.61\end{array}$ & $\begin{array}{r}47.53 \\
0.38 \\
0.13 \\
0.29 \\
48.94 \\
0.26 \\
0.85 \\
1.63\end{array}$ & $\begin{array}{r}39.18 \\
0.46 \\
0.13 \\
0.27 \\
56.24 \\
0.26 \\
0.56 \\
2.90\end{array}$ & $\begin{array}{r}39.51 \\
0.22 \\
0.13 \\
0.45 \\
56.61 \\
0.27 \\
0.41 \\
2.39\end{array}$ & $\begin{array}{r}42.88 \\
0.38 \\
0.13 \\
0.28 \\
52.67 \\
0.27 \\
0.92 \\
2.45\end{array}$ & $\begin{array}{r}30.39 \\
0.40 \\
0.13 \\
0.25 \\
67.13 \\
0.28 \\
0.32 \\
1.11\end{array}$ & $\begin{array}{r}43.01 \\
0.21 \\
0.12 \\
0.26 \\
52.26 \\
0.25 \\
0.62 \\
3.27\end{array}$ & $\begin{array}{r}44.54 \\
0.37 \\
0.13 \\
0.29 \\
51.11 \\
0.27 \\
0.65 \\
2.65\end{array}$ & $\begin{array}{r}45.45 \\
0.49 \\
0.13 \\
0.28 \\
50.23 \\
0.26 \\
0.84 \\
2.31\end{array}$ & $\begin{array}{r}41.75 \\
0.17 \\
0.13 \\
0.28 \\
53.98 \\
0.27 \\
0.52 \\
2.91\end{array}$ & $\begin{array}{r}46.31 \\
0.15 \\
0.13 \\
0.29 \\
49.82 \\
0.26 \\
1.00 \\
2.04\end{array}$ & \\
\hline
\end{tabular}

Notes: UNE number refers to the ash layer number analyzed at UNE (see Tables I and 2). All totals are normalized to $100 \%$, volatile free. All Fe reported as FeO*.

Table 15. Representative analyses of clinopyroxene (cpx) and amphibole.

\begin{tabular}{|c|c|c|c|c|c|c|c|c|c|c|}
\hline & cpx & cpx & cpx & $\operatorname{cpx}$ & $\operatorname{cpx}$ & cpx & cpx & cpx & amphibole & amphibole \\
\hline $\begin{array}{l}\text { Hole: } \\
\text { UNE number: }\end{array}$ & $\begin{array}{c}881 \mathrm{~B} \\
13 \\
\end{array}$ & $\begin{array}{c}881 \mathrm{~B} \\
28\end{array}$ & $\begin{array}{c}882 \mathrm{~A} \\
64\end{array}$ & $\begin{array}{c}882 \mathrm{~A} \\
66\end{array}$ & $\begin{array}{c}882 \mathrm{~A} \\
70\end{array}$ & $\begin{array}{c}882 \mathrm{~A} \\
73\end{array}$ & $\begin{array}{c}883 \mathrm{~B} \\
90\end{array}$ & $\begin{array}{c}887 \mathrm{~A} \\
171 \\
\end{array}$ & $\begin{array}{c}881 \mathrm{~A} \\
2\end{array}$ & $\begin{array}{c}881 \mathrm{~B} \\
11\end{array}$ \\
\hline $\mathrm{SiO}_{2}$ & 51.30 & 50.86 & 52.77 & 50.74 & 51.33 & 50.74 & 51.63 & 52.03 & 45.93 & 55.01 \\
\hline $\mathrm{TiO}_{2}^{-}$ & 0.41 & 0.36 & 0.38 & 0.61 & 0.51 & 0.69 & 0.55 & 0.35 & 1.05 & 0.14 \\
\hline $\mathrm{Al}_{2} \mathrm{O}_{3}$ & 1.89 & 1.73 & 2.53 & 2.68 & 2.85 & 3.12 & 2.13 & 1.62 & 12.25 & 12.26 \\
\hline $\mathrm{Cr}_{2} \mathrm{O}_{3}$ & 0.13 & 0.13 & 0.13 & 0.13 & 0.13 & 0.13 & 0.13 & 0.13 & 0 & 0 \\
\hline $\mathrm{FeO} *$ & 12.59 & 14.24 & 8.76 & 10.35 & 9.56 & 8.85 & 18.06 & 8.94 & 9.94 & 14.79 \\
\hline $\mathrm{MnO}$ & 0.46 & 0.77 & 0.55 & 0.37 & 0.23 & 0.31 & 0.62 & 0.79 & 0.12 & 0.14 \\
\hline $\mathrm{MgO}$ & 15.52 & 11.92 & 14.84 & 15.17 & 15.69 & 15.25 & 17.00 & 15.11 & 16.71 & 15.69 \\
\hline $\mathrm{CaO}$ & 17.50 & 19.79 & 19.63 & 19.76 & 19.50 & 20.55 & 9.69 & 20.77 & 11.62 & 1.62 \\
\hline $\mathrm{K}_{2} \mathrm{O}$ & & 0 & 0 & 0 & 0 & 0 & 0 & 0 & 0.36 & 0.16 \\
\hline $\mathrm{Na}_{2} \mathrm{O}$ & 0.20 & 0.20 & 0.41 & 0.19 & 0.19 & 0.34 & 0.20 & 0.25 & 2.02 & 0.20 \\
\hline
\end{tabular}

Notes: UNE number refers to the ash layer number analyzed at UNE (see Tables I, 2, 3, and II). All totals are normalized to 100\%, volatile free. All Fe reported as FeO*. 